WOOERT DOGS (Gon-Sporting).

RAWDOE 1B. HaE. 

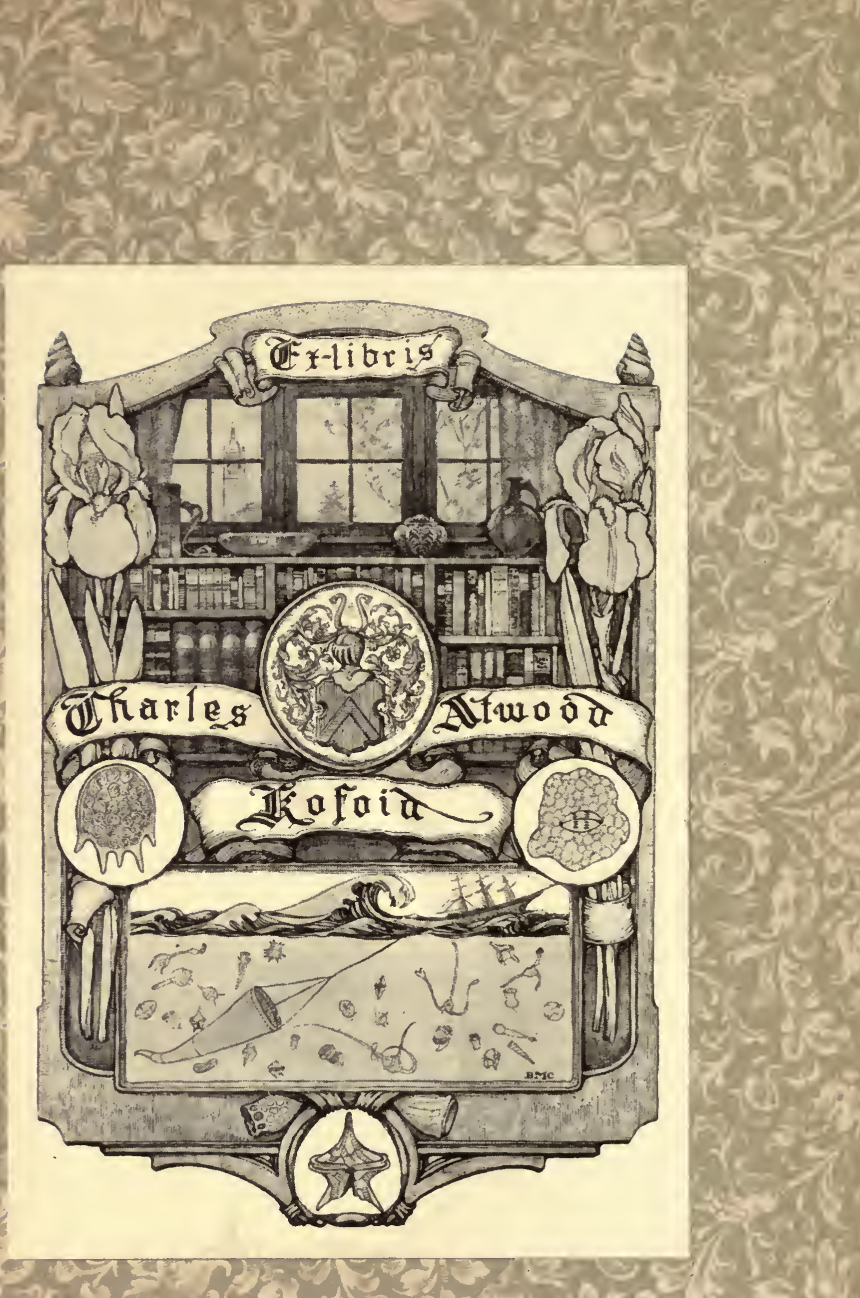

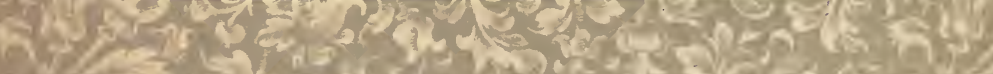

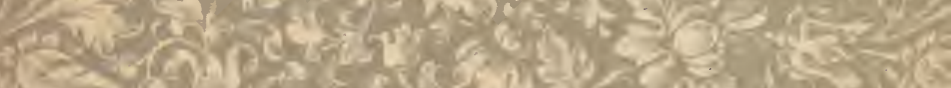

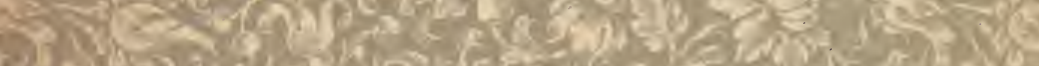

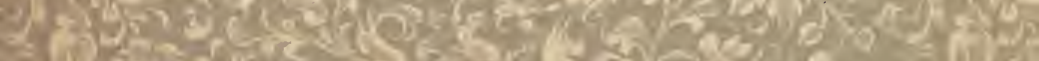

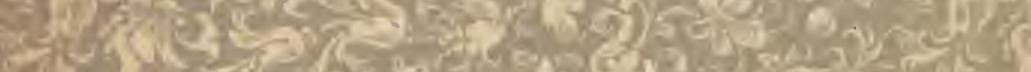




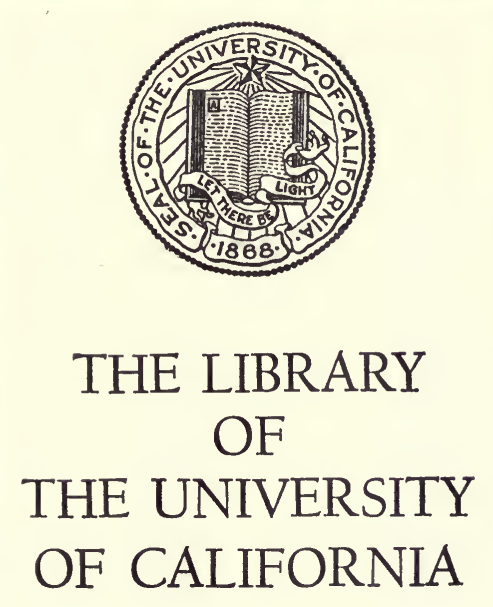

PRESENTED BY

PROF. CHARLES A. KOFOID AND MRS. PRUDENCE W. KOFOID 


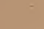

$\therefore$

$$
\text { . }
$$$$
\text { - }
$$

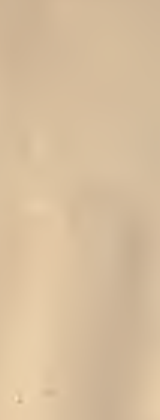

4 


Modern Dogs.

Non-Sporting Division. 
<smiles>C1CC1</smiles> 



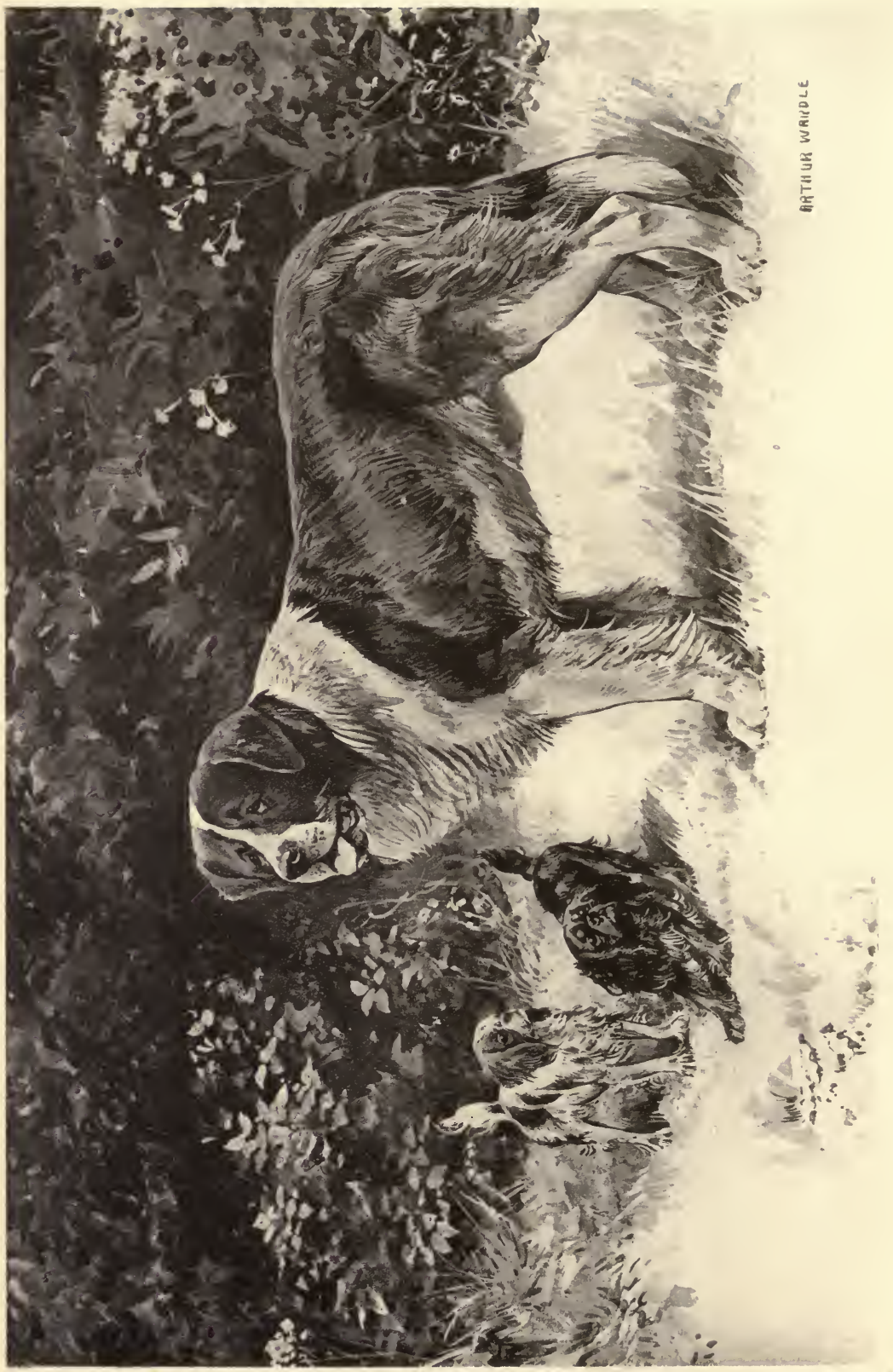


A

\section{HISTORY AND DESCRIPTION}

OF THE

\section{MODERN DOGS}

OF

GREAT BRITAIN AND IRELAND.

(NON-SPORTING DIVISION.)

BY

RAWDON B. LEE,

KENNEL EDITOR OF “THE FIELD," AUTHOR OF THE HISTORIES OF

"THE FOX TERRIER," “THE COLLIE," ETC.

THE ILLUSTRATIONS BY

ARTHUR WARDLE AND R. H. MOORE.

LONDON :

HORACE COX,

"FIELD" OFFICE, WINDSOR HOUSE, BREAM'S BUILDINGS, E.C 1894 . 
LONDON:
PRINTED BY HORACE COX, WINDSOR HOUSE, BREAM's BUILDINGS, E.C. 


\section{SF427 4287}

\section{PREFACE.}

THE publication and success of my book last year on "Sporting Dogs" has necessitated the production of another division dealing with the "NONSPORTING" varieties, in which terriers are not included, they forming a volume of themselves. I have endeavoured to give a somewhat complete early history of the different breeds, and, at the same time, have brought the subject up to date.

As before, the drawings, although in most instances taken from living examples, are not intended to be merely counterparts of dogs of the day, but they must be taken as illustrative of the typical specimens they represent. I believe this departure from ordinary custom to be a useful one, as the portraits of individual dogs, whose 
prominence before the public is more or less ephemeral, cannot in the future be of so much interest as pictures of idealised animals are likely to be.

In cases where the specialist clubs have compiled and arranged descriptions of the dogs whose interests they guard, I have given the results of the deliberations of their members. I have likewise appended scales of points to satisfy those who, in the minority, still believe that the beauty or otherwise of a dog can be correctly gauged by a series of figures.

The illustrations by Arthur Wardle and R. H. Moore are, I consider, particularly satisfactory, as is the process by which they are reproduced.

My thanks I convey to all who have assisted me in providing subjects for the artists, and to others who have given valuable information, not to be obtained excepting from owners who have made individual varieties of the dog special studies. 
To all who have assisted me I dedicate this work, as some slight return for their kindness and for the interest they have taken in its publication.

\section{RAWDON B. LEE.}

Brixton, London, March, 1894. 



\section{CONTENTS.}

CHAPTER I.

The Mastiff .

CHAPTER II.

The St. Bernard . . . . . . . . . . .

CHAPTER III.

The Newfoundland

CHAPTER IV.

The Collie or Sheep Dog . . . . . . . 105

CHAPTER V.

The Smooth-coated Sheep Dog . . . . . 139

CHAPTER VI.

The Old English (Bob-talled) Sheep Dog . . 145

CHAPTER VII.

The Poodle . . . . . . . . . . . I6I

CHAPTER VIII.

The Dalmatian . . . . . . . . . . . . IgI 
CHAPTER IX.

The Bulldog.

CHAPTER X.

The Pug Dog . . . . . . . . . 253

CHAPTER XI.

The Black Pug.

CHAPTER XII.

English Toy Spaniels . . . . . . . . . 279

CHAPTER XIII.

The Japanese Spaniel . . . . . . . . . 3or

CHAPTER XIV.

The Maltese . . . . . . . . . . . 313

CHAPTER XV.

The Pomeranian

CHAP'TER XVI.

The Italian GReyhound . . . . . . . 335

CHAPTER XVII.

THE SCHIPPERKE

CHAPTER XVIII.

The Chow Chow . . . . . . . . . . . . . 353 


\section{ILLUSTRATIONS.}

St. Bernard and Toy Spaniels. . Frontispiece. MASTIFFS . . . . . . . . Facing page I St. Bernard (Rough-COATEd) . . " 37 St. Bernard (Smooth-COATED) . . . . 49 NEWFOUNDLANDS • • • • • • • " $\quad 79$ COLlie . . . . . . . . . . . . . . . . Smooth-CoAted Collies . . . . " " Old English Sheep Dogs . . . . ” POODLES. . . . . . . . . . . . . Corded Poodles . . . . . . . . " , 177 DalmatianS • . . . . . . . . . " Bulldogs . . . . . . . . . . . " , 205 PUg Dogs . . . . . . . . . " " 253 Black Pugs . . . . . . . . . . . " " 269 King Charles and Blenheim Spaniels " $\quad 279$ Ruby and Prince Charles Spaniels . " " 287 JaPANESE SPANIELS . . . . . . " 
Maltese - . . . . . . . Facing page $3 \mathrm{I} 3$

Pomeranians . . . . . . . . . "

ITALIAN GREYHOUNDS. . . . . . . " $\quad 335$

SCHIPPERKES . . . . . . . . " 347

CHOW ChOWS . . . . . . . . . " , 353 



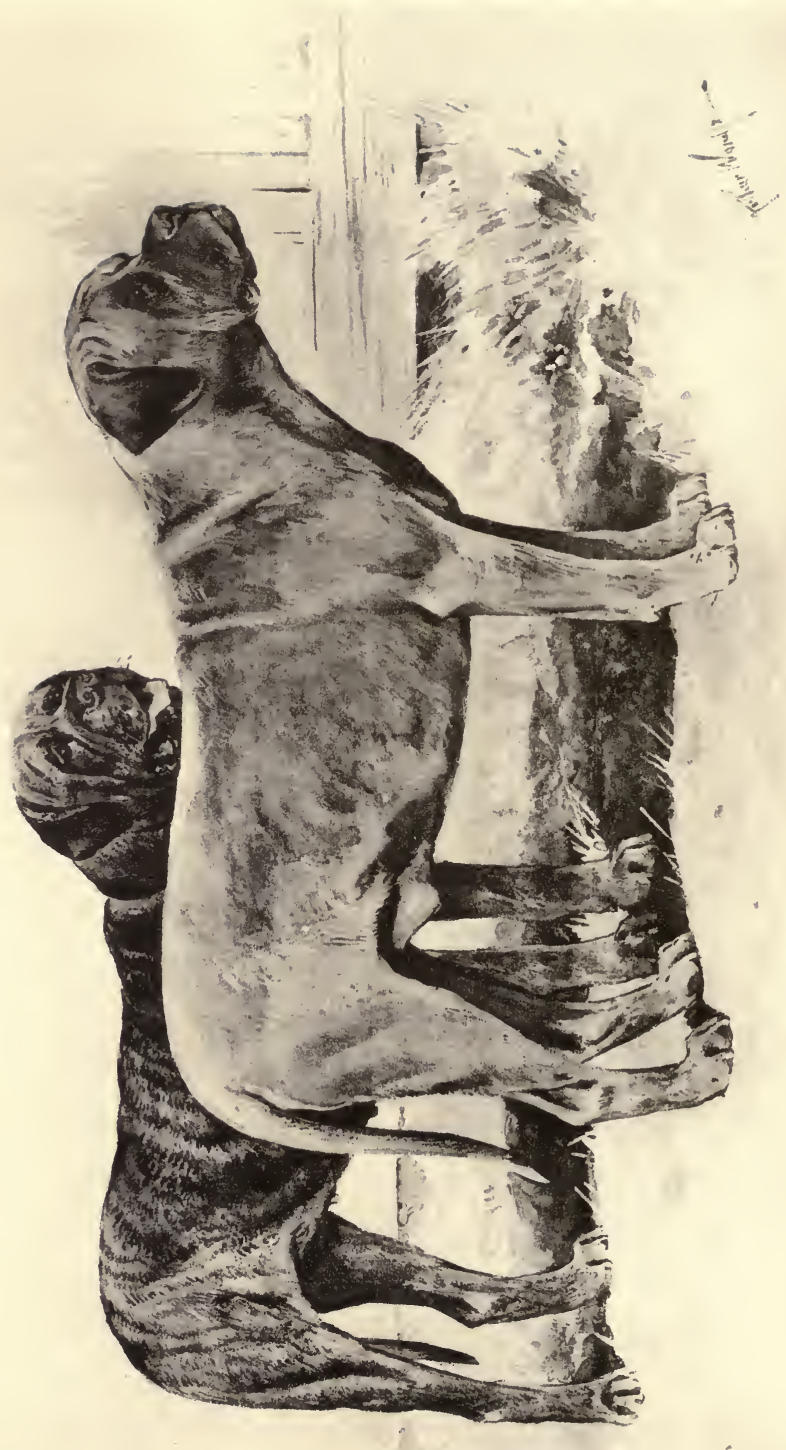




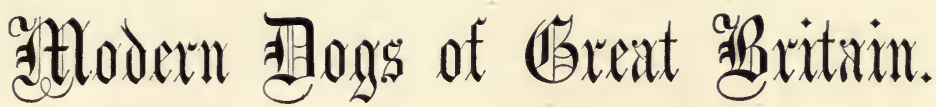

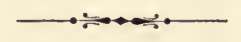 \\ CHAPTER I. \\ THE MASTIFF.}

Quite recently a somewhat interesting correspondence has taken place in the Field regarding what some contributors called the "deterioration of the mastiff," implying by these words that the old English mastiff of the present day was not equal to what it had been, say, twenty-five years or so ago. Whether this is the case or not it would be difficult to determine from what was written by those engaged in the controversy, for, as is always the case with ordinary newspaper discussions, the general reader was about as wise at its termination as he was at the beginning. There is, however, no doubt that the modern mastiff breeder, in allowing a craze for huge heads and great skulls to get the better of him, has, as a rule, produced these exaggerations to the sacrifice of 
the body, loins, legs, and general symmetry of the animal.

This was, however, so marked about two years ago that even those who had been the means of causing such retrogression noticed the error they had made, and are now, I fancy, doing their best to remedy their mistake. So, possibly in a couple of years more, our race of mastiffs will have become more symmetrical, will have lost their cow-hocks, crooked fore legs, and hollowed backs, which combined render their gait an awkward rolling movement, more like that of an aged shorthorn going into the byre than that which ought to be possessed by a leading family of the canine race.

Some of our modern mastiffs of the Crown Prince strain would, I am afraid, have made but sorry protectors for an English warrior who lay grievously wounded on the field of Agincourt.

Although considerable diversity of opinion has existed, and will always exist, as to the origin of the mastiff, there is little doubt that it is the oldest variety of dog connected with Great Britain, and upon this most authorities appear to be agreed, though there are occasional admirers of the bulldog who would have us believe that that variety of the canine race was one of the original dogs of the British Isles. History has told us that during 
the time of the Roman occupation of Britain, an officer was appointed with the title of Procurator Cynegii, whose business it was to obtain and transmit to Rome mastiffs that would prove useful as guards and, mayhap, in fighting in the arena either amongst themselves or with wild beasts. At about this period every two "villeins" were by law compelled to keep between them one mastiff dog, and the duties of the Procurator would, no doubt, be to collect the dogs, when fully grown, from these common people. Strabo tells us that the same mastiffs were used by the Gauls in times of war.

The Rev. M. B. Wynn, in his "History of the Mastiff," has been most praiseworthy in his researches as to the origin of the mastiff, and, I believe, has collected facts together which ought to convince even the most sceptical of the identity of the mastiff with that large dog which the Romans found in this country, and which they afterwards made useful and amusing in their degrading sports of the arena. There are numerous illustrations on various pieces of ancient RomanBritish pottery which can easily be identified as representing a dog of the mastiff type, such a one as some nineteen hundred years or more ago might be found in this country, and utilised as guard to the flocks and herds, protecting them by their 
size, strength, and ferocity from the wolves that then overran the country.

There might at the same time be a smaller variety of the same dog, but of this there is no proof, and that the early mastiff was quite different from the early bulldog in leading particulars may be safely inferred, especially when, in support thereof, there are extant illustrations dating from the Roman period where the mastiff is attacking a horse, which he is represented as doing from behind, and not flying at the nose or front, which is the natural seizing place of the true bulldog.

Mr. Wynn further says that in 1823, in a work entitled "Roman Antiquities, or the Durobrivæ of Antonicus Identified," there is a picture of a mastiff galloping after a horse, and, judging from the relative size of, the two animals, which are both carefully and accurately delineated, such dogs must have been from 28 to 30 inches at the shoulder, heads broad and full, muzzle very short and broad, ears small and partially erect. Their necks and bodies are massive, limbs short and stout, sterns fine, and the tout ensemble that of long-bodied, muscular, heavy mastiffs. The same writer proceeds to say that such instances are proof of what the mastiff was say between A.D. I 00 and I 50, which would be about the time the vessels were made upon which 
the figures were represented, and from which the engravings were taken. "These," the author of the "History of the Mastiff" proceeds to say, "are the best drawn and most reliable evidences I have met with, and it would be ridiculous to class such dogs as bulldogs, with their manner of attack and large size; yet their broad skulls and short muzzles show their close affinity to the British bulldog."

There are other illustrations of large dogs extant taken from ancient pottery, and in some of them the ears of the animals are shown as cut, the latter no doubt done to prevent the aural appendages being torn, either when the dogs were fighting with each other, or with some wolf, or fox, or badger.

However, it would occupy too much space were I to enter fully into the origin of the mastiff and describe him seriatim from the earliest days to the present time. He was early known as the Alaun or Alan, the Molossus, and later, according to some authorities, as the Bulldog, but I should be inclined to believe-nay, do in reality believe-that our modern mastiff, as he appears on the show bench to-day, is very far removed from what he was when Julius Cæsar first landed on our shores, and although Mr. Wynn, Mr. H. D. Kingdon, and others have endeavoured to trace the breeding of these favourite dogs for many years back, their 
labours have not had a successful result. A dog's pedigree for a hundred years, excepting, maybe, in a foxhound or greyhound, is not to be compiled with any degree of exactitude. Still there have been in this country, from earliest records to the present time, a breed of dog that has done duty as the mastiff, and so well has he performed his part that he may be well called the most historical dog of the day.

By the Romans and some others he was abased by the purposes to which he was put, for I do not believe he was ever intended as a hunting dog, or for the purpose of fighting with much more powerful beasts than himself. It has been said that King James I. loosed a powerful mastiff against a lion, to the discomfiture of the former, and a kennel companion met a like fate. But a third dog did so much better, worsting his antagonist, that the King said, "He that had fought the king of beasts should never fight a meaner creature," and forthwith this good "mastive" became a pensioner on the royal bounty. This is said to have happened in 1604, and about sixteen years later the same monarch prohibited bear-baiting on a Sunday. At this time it was the custom to crop the ears of most of the mastiffs, and in some cases their sterns were shortened likewise. 


\section{The Mastiff.}

As I have already hinted, the mastiff was not originally a fighting dog; he was used as a watch and guard, and as such had special legislation given him so far back as the reign of Henry III., when the obnoxious Forest Laws were still in operation. At that time, and ever since William the Conqueror had appeared on the scene, no ordinary individual was allowed to keep a dog within the precincts of the Forests, though a special provision was made for mastiffs kept by farmers and substantial freeholders dwelling therein; indeed, no other dog than a mastiff was allowed to be kept within these precincts. They might keep such dogs for the protection of their houses and stock, provided that such dogs be expeditated according to law. This iniquitous law was carried out by cutting off the claws of the fore feet close to the skin. The operation was performed by "sitting one of the fore feet upon a piece of wood eight inches thick and a foot square, and with a mallet, setting a chisel of two inches broad upon the three claws of his fore feet, and at one blow cutting them clean off. And this expeditating (by some called $\mathrm{h}^{\wedge}$ mbling or lawing of dogs) ought to be looked af er by the caretaker of the forest every third year."

Dr. Caius, so well known and so often quoted 
by writers on canine matters, ought not to be omitted here, as he flourished about I550, when little was said about the dog, although it was more valued during his period than it had been earlier. He says, "the mastiff or ban dog is vast, huge, stubborn, ugly, and eagre, of a heavy and burdensome body, and therefore but of little swiftness, terrible and frightful to behold, and more fierce and fell than any Arcadian cur, notwithstanding they are said to have their generation from the valiant lion. They are called Villatica, because they are appointed to watch and keep out-of-theway farm places. . . . . They are serviceable against the fox and badger, to drive wild and tame swine out of meadows, \&c., and to bait and take the bull by the ear when occasion requireth.

For it is a kind of dog capable of courage violent and valiant, striking fear into the hearts of man, and standing in fear of no man, and no weapon will make him shrink or abridge ' his boldness."

Caius goes on to say these dogs are trained to bait the bear and other "cruel beasts" without "any collar to defend their throats," and oftentimes they train them up in fighting and wrestling a man, who having for a safeguard either a pikestaff, a club, or a sword, and by using them to such 
exercises as these, the dogs become more sturdy and strong." Here the duties of the mastiff appear to have been of a varied character, if not altogether a pleasant one, and it would be a dog to be avoided by the general public.

Conrad Heresbach, of Cleves on the Rhine, who flourished, as the school books say, about the middle of the sixteenth century, he being born in I 509 and dying in 1576 , in his book of Husbandry, translated into English by Barnaby Goodge, calls the mastiff "the ban dog for the house. Such a one should have a large and mighty body, a great and shrill voice, that both with his barking he may discover and with his sight dismay the thief; yea, not being seen, with the horror of his voice put him to flight. His stature must neither be too long nor too short, but well set; his head great, his eyes sharp and fiery, either brown or grey; his lippes blackish, neither turning up nor hanging too much down; his mouth black and wide; his neather jaw fat, and coming out on either side of it a fang appearing more outward than his other teeth; his upper teeth, even with his neather, not hanging too much over, sharp and hidden with his lips; his countenance like a lion; his breast great and shaghaired; his shoulders broad, his legs big, his tail short, his feet very great. His disposition must 
be neither too gentle nor too curt, that he must neither fawn upon a thief nor flee upon his friends; very waking, no gadder abroad nor lavish of his mouth, barking without cause; neither make it any matter though he be not swift, for he is but to fight at home, and to give warning to the enemy."

Whether some of our modern breeders have endeavoured to produce an animal similar to that described by Conrad Heresbach one cannot tell, but from the "very great feet" often seen nowadays, and the decided slowness in their paces of others, it might be thought a return to the dog as described in the middle of the seventeenth century had been sought to be brought about. Certainly I have seen prize winning modern mastiffs that would, from sheer inability, not be "gadders abroad."

To come to modern times a huge leap of over many centuries must be made, but before actually entering upon a description of the race as it is at present, an omission would be caused were the Lyme Hall mastiffs to be omitted. It has been said that at the seat of the Leghs at Lyme Hall, in, Cheshire, a strain of mastiffs has been kept intact for many years. This is, however, not the case. On a recent visit to the ancient residence I found but about seven mastiffs present, and these were of a very inferior character in every way. 
Without distinctive feature, there was one dark fawn dog, others light fawn with black muzzles, and an animal that had been obtained to improve the strain that would have been best relegated to the tan yard. I was sorry to come to the conclusion that the Lyme Hall mastiff, with its historical traditions, was become a thing of the past, its place being usurped by inferior specimens not good enough to obtain a prize at any of our smallest dog shows. For the sake of his ancient repute it would have been better had the mastiff of the Leghs been allowed to entirely disappear, like the wild cat:le which not many years ago grazed in the adjoining park, than to degenerate into the poor creatures we saw in the kennels there a few months ago.

Some twenty years or so since, my friend $\mathrm{Mr}$. H. D. Kingdon did his best to restore life and give prominence to the Lyme Hall strain, but his energy was entirely thrown away, and the few dogs he did bring forward were small and poor creatures in comparison with the superb specimens that had for some time emanated from other kennels. About half a century ago there was a turning point in the history of the mastiff, which the succeeding establishment of dog shows facilitated.

Is the story of the origin of the Lyme Hall mastiff too stale to be reproduced here? On St. 
Crispin's day, October 25th, 1415, the battle of Agincourt was fought, and the English had a decisive victory over their Gallic neighbours. Sir Peers Legh, of Lyme Hall, fighting for the victors, lay wounded on the field, and when found by his comrades he was guarded by a magnificent mastiff bitch, who did not leave her master until he died of his wounds in Paris, whither he had been removed. The bitch pupped shortly afterwards, but this did not prevent the warrior's family making arrangements for the conveyance of the knight's protector and her family to Lyme Hall, whither the corpse was taken for subsequent interment in the private vault of the Legh's, within the walls of Macclesfield Parish Church. From these puppies there sprung what was once supposed to be a pure strain of mastiffs. But history is silent about even the parent bitch herself, although it has been stated positively that the Lyme Hall strain was descended from dogs born generations before Agincourt was won. I do not think that anyone who wishes to improve his strain of mastiffs to-day would fly to the Lyme Hall Kennels for the purpose.

At the time of my visit, there was a very fine painting by Nettleship, about 1876 , of a mastiff, and a right good dog too, evidently quite as good as Miss Aglionby's Turk, and some others that 
have had more to do with the foundation of our present strain than some people would imagine.

The Duke of Devonshire had an old strain of mastiffs at Chatsworth, but this has been lost, and so have those that were once known at Elvaston Castle, near Derby, in the family of the Galtons.at Hadzor Hall, Worcester. There had been a special strain at the Duke of Sutherland's, at Trentham, and the author of the "History of the Mastiff" mentions strains kept by Colonel Wilson Patten, at Bold Hall, which had been at this seat since its occupation by the Honourable Peter Bold; and later by Mr. John Crabtree, of the Kirklees Park, near Halifax. The latter was head gamekeeper to the Armitage family, and he, about i 820 , came into the possession of a brindled mastiff bitch, which he found caught in one of his fox traps that had been set in the park. From this bitch, and by judicious crossing, he obtained a strain of dogs highly spoken of by Mr. Wynn, which, it seems, Mr. F. Crabtree used principally as assistants to himself and his under-trappers in the apprehension of poachers.

Mr. J. W. Thompson, another Yorkshireman, about 1830 and later, gave considerable attention to the breeding of mastiffs, but to Mr. H. V. Lukey, of Morden, Kent, must modern admirers 
of the mastiff turn to find the man who has done most to improve or to develop the breed. His first mastiff came into his possession about 1835 . This was a brindled bitch, with cropped ears and docked tail, said to be an Alpine mastiff from the kennels of the Duke of Devonshire. This seems to be something of an anomaly, though vouched for both by the late Mr. Lukey and by Mr. Wynn, and the latter tells us the ears of the Alpine mastiffs were cut to prevent them becoming frost bitten. Personally, I should think they would be far more likely to suffer from the attacks of frost-bite when cruelly cut than if left intact. However, this by the way.

The bitch in question was obtained from a dealer named White, at Knightsbridge, who was the predecessor of the late Bill George, of such great celebrity as a dog dealer, and father to the present Alfred George, of Kensal Town, equally well known in canine matters. This bitch mated to a black dog belonging to the Marquis of Hertford, produced two puppies, one of which died. The other, a bitch, was in time put to another so-called "Alpine mastiff," and so came Mr. Lukey's and subsequent modern strains.

It would seem strange that, with all the pride Englishmen have had in their dogs and in the ancient 
reputation they have borne, that of our modern mastiff so much is due to an animal that was known as the Alpine mastiff, and which in reality cannot have been more nor less than a smoothcoated St. Bernard. One writer has written that the black dog of Lord Hertford's was a Thibet mastiff. Most likely he was a very dark coloured brindled $\operatorname{dog}$ of our English strain, for certainly none of Mr. Lukey's dogs ever showed the hound type and bloodhound expression which would have been obtained from a cross with a Thibetian dog; and if it had been used, the evil would have kept cropping up generation after generation.

Writing in "Dogs of the British Isles," Captain Garnier came into prominence as a mastiff breeder, and his communication is worth reproducing here in part. He says :

About this time (1847) I bought of Bill George a pair of mastiffs, whose produce, by good luck, afterwards turned out some of the finest specimens of the breed I ever saw. The dog Adam was one of a pair of Lyme Hall mastiffs, bought by Bill George at Tattersall's. He was a different stamp of dog to the present Lyme breed. He stood $30 \frac{1}{2}$ in. at the shoulder, with length of body and good muscular shoulders and loins, but was just slightly deficient in depth of body and breadth of forehead; and from the peculiar forward lay of his small ears, and from his produce, I have since suspected a remote dash of boarhound in him. The bitch was obtained by Bill George from a dealer in Leadenhall Market. Nothing was known of her pedigree, but I am as convinced of its purity as I am doubtful of that of the dog. 
There was nothing striking about her. She was old, her shoulders a trifle flat, and she had a grey muzzle, but withal stood 29 in. at the shoulder, had a broad round head, good loin, and deep, lengthy frame. From crossing these dogs with various strains I was easily able to analyse their produce, and I found in them two distinct types-one due to the dog, very tall, but a little short in the body and high on the leg, while their heads were slightly deficient in breadth; the other due to the bitch, equally tall, but deep, lengthy, and muscular, with broad massive heads and muzzles. Some of these latter stood 33 in. at the shoulder, and by the time they were two years old weighed upwards of Igolb. They had invariably a fifth toe on each hind leg, which toe was quite distinct from a dew-claw, and formed an integral portion of their feet. By bad management, I was only able to bring a somewhat indifferent specimen with me on my return to England from America-a badly reared animal, who nevertheless stood $32 \mathrm{in}$. at the shoulder, and weighed r $70 \mathrm{lb}$. This dog Lion was the sire of Governor and Harold, by Mr. Lukey's bitch Countess, and so certain was I of the vast size of the breed in him that I stated beforehand, much to Mr. Lukey's incredulity, that the produce would be dogs standing $33^{\mathrm{in}}$. at the shoulder-the result being that both Governor and his brother Harold were fully that height. In choosing the whelps, Mr. Lukey retained for himself the best marked one, an animal that took after the lighter of the two strains that existed in the sire; for Governor, grand dog and perfect mastiff as he was, compared to most others of the breed, was nevertheless shorter in the body, higher on the leg, and with less muscular development than Harold, while his head, large as it was, barely measured as much round as did his brother's. I, who went by the development of the fifth toe (in this case only a dew-claw), chose Harold, a dog which combined all the best points, except colour, of both strains, and was a very perfect reproduction on a larger scale of his dam Countess. This dog was the finest male specimen of the breed I have met with. His rreast at ten months old, standing up, measured I 3 in. across, with a girth of $4 \mathrm{I}$ in., and he weighed in moderate condition $\mathrm{r} 4 \mathrm{Olb}$., 


\section{The Mastiff.}

and at twelve months old I6olb., while at $13 \frac{1}{2}$ months old Governor only weighed in excellent condition I5olb., with a girth of 4oin.; and inasmuch as Governor eventually weighed I $80 \mathrm{lb}$. or even more, the size to which Harold probably attained must have been very great. His head also in size and shape promised to be perfect.

I will mention three other dogs. The first, Lord Waldegrave's Turk, better known as "Couchez," was the foundation of Mr. Lukey's breed. This dog has frequently been described to me by Bill George and Mr. Lukey, and I have a painting of his head at the present moment. He stood about $29 \frac{1}{2}$ in. or 3 oin. at the shoulder, with great length and muscular development, and, although he was never anything but thin, weighed about I3olb. Muzzle broad and heavy, with deep flews; skin over the eyes and about the neck very loose; colour red, with very black muzzle. He was a most savage animal; was fought several times with other animals, and was invariably victorious. The second was a tailless brindled bitch, bought by Mr. Lukey from George White, of Knightsbridge. She was a very large massively built animal, standing 3 oin. at the shoulder. Her produce with Couchez were remarkably fine. "Long-bodied, big-limbed, heavy-headed bitches. They were mastiffs Mr. Lukey had in those days!" is Bill George's eulogium of them. This bitch was bred by the Duke of Devonshire, and must therefore have been one of the Chatsworth breed. The third animal, L'Ami, was a brindled dog of such vast size and weight that he was taken about and shown in England, in the year 1829 , the price of admission being one shilling. Of the head of this dog also I have a drawing, and it shows him to be very full and round above the eyes, with a broad heavy muzzle and remarkably deep flews, the ears being cropped close. This dog, with the exception of rather heavy flews, answered exactly to the type of Vandyke's mastiff.

Now the point to which I wish to draw attention is, that both Couchez and L'Ami came direct from the Convent of Mount St. Bernard. The mighty dogs which used to be kept at Chatsworth (and one of which stood 34in. at the shoulder) were pure Alpine mastiffs, as also were the two magnificent animals 
I have mentioned as having seen at Bill George's kennels some sixteen years ago; while others that I frequently used to meet with at that time were of the same character. These, one and all, presented the same type-a strong proof of their purity-and that type was in all respects the same as the old English mastiff portrayed by Vandyke. The same may be said of the dogs in Landseer's picture of Alpine mastiffs, which have all the points of the true mastiffs, although their tails, as might be expected from the cold climate, are hairier than they should be. At that time one used to meet with good English mastiffs also, but they were few compared to the number of half-bred animals that went by that name; and, with the exception of Mr. Lukey's breed, the good ones have nearly all come from Lancashire, Cheshire, and the north of England generally, where some years ago they were still in considerable request for guarding the large bleaching grounds. Between these and the Alpine dogs I never could discover the slightest difference except in size-the best English dogs varying from 2 gin. to 33 in. at the shoulder, while the Alpine male specimens were seldom under 3 in.

Now, it is ridiculous to suppose that the dogs that used to be found at the convent, and in a few of the Swiss valleys, were a breed indigenous to that small part of the continent of Europe; and yet it was there only that the breed existed. When, therefore, we find the same animal common in England two hundred years ago, and still to be met with in considerable numbers, though more rarely than formerly, it is only reasonable to conclude that the English and Mount St. Bernard mastiffs are identical breeds, and that the monks, requiring large, powerful, generous, and highcouraged animals for their benevolent purposes, selected the old English dog in preference to all other breeds. It is very easy to understand that, with the disuse of the breed for combating wild animals, they should have been allowed to die out and degenerate in England; and it is equally easy to understand that the mastiffs kept at the Convent of St. Bernard for a particular purpose, requiring strength and courage, should have been kept up, and thus that the best specimens of the breed in modern times have come from there. 
The above opinion of Colonel Garnier's, written, say, a quarter of a century ago, will scarcely find favour now. There is not the slightest similarity between the smooth St. Bernard and the mastiff, and our English bred specimens of the former are all, as a rule, bigger and heavier than any animals that have been imported. Nor can I see any resemblance, excepting, perhaps, in size, between Landseer's Alpine mastiffs, painted in the early part of that great artist's career, and our own English mastiff. No doubt crosses with some foreign bred dogs were introduced sixty years ago, and even more recently, but at that time canine education was not far advanced, and a dog with a foreign name would bring more money in the market than one that bore a national nomenclature. On this account I fancy pedigrees became somewhat mixed, and, reading all that has been written by Colonel Garnier and others, it would be difficult to believe in the British mastiff as little more than a mongrel rather than as a direct descendant of all that is old in our English dogs.

We hear of the bulldog cross and the bloodhound cross; but when were they introduced, and by whom? These are important questions, which have not hitherto been answered. There is no doubt that amongst modern mastiffs specimens 
quite frequently occur that show in the round, broad skull, sunken eyes, and, shall I say, the undershot jaw, a decided leaning to the bulldog in expression. Some admirers of the breed say the mastiff ought to be undershot, and that he was so originally. A perfect mastiff ought to be as level in his teeth as a terrier. He should have a distinctive character of his own, not of the bulldog as above described, nor of the hound with a long square face, with loose skin under his throat, and deeply pendulous dewlaps.

Such dogs as I have in my mind bore none of these defects. They looked mastiffs pure and simple, and were such from the end of their noses to the tips of their tails. As my paragon I always took that grand dog Turk, who was bred by the late Miss Aglionby at Esthwaite Hall, near Hawkshead, one of the Lancashire portions of the English lake district. This fine dog, born in 1865 , was one of an extraordinary litter by Mr. E. Field's King from the breeder's Hilda, the one whelping including Wolf, which his fair owner considered the better dog, Knight Templar, Emperor, and Turk. Thus there were four dogs in the same litter the like of which could scarcely be bred in twenty litters to-day. How these dogs won in classes that were far stronger then than now, and for years 
after likewise, is a matter of history. In I 87 I sixtynine mastiffs were benched at one of the Crystal Palace shows, and at Birmingham the same year there were twenty-nine competitors in the open dog class. There were men at that time who bred their dogs with care, and they had not commenced to breed for exaggerated heads to the sacrifice of qualities equally important.

Earlier than the Turk epoch, Mr. E. Hanbury, from Wiltshire, was showing some good dogs, and not many years later Mr. E. Nichols, of South Kensington, who survives, and takes as much interest in them as ever, would not look at any dog that possessed the round bull-headed skull introduced a little later. Bill George's Tiger, whose name will be found in the pedigrees of most modern mastiffs, was no great wonder in the way of size, but his head was correctly shaped, and if he was underhung at all it was very little. I never saw the dog myself, but whilst one authority says .Tiger's lower jaw protruded, I am told that this was not the case. Mr. Lukey's Governor was not undershot, but no doubt some of the early dogs were so deformed, still with this defect they had not the additional ones of crooked and too twisted hocks, so prevalent as I write in 1893 . 
Other fine dogs that were not underhung were Mr. C: Bathurst's Peveril, Mr. Hanbury's Rajah, Sir T. Fermor Hesketh's Nero, Mr. Ralph Yeardsley's Anlaf, a son of Mr. M. B. Wynn's Monarch, and later Mr. Dickenson's Lion and Mrs. Rawlinson's Hector, with many others that could be mentioned, and with so much good stuff to breed from, the wonder is that the defects alluded to have not died out rather than increased. Then there is no getting away from the fact that the more any of the modern mastiffs resemble the bulldog in head, the greater probability that they resemble him in his walk-or waddle rather-a gait certainly quite out of place in a typical mastiff.

To my idea, that dog Crown Prince, who was bred by Mr. Woolmore in I880, has much to answer for, so far as the present defects in the mastiff are concerned. He was a peculiarly coloured fawn dog, known to fanciers as "Dudley-faced "- that is, his nose was red, his eyes had a similar inclination, and a yellow redness pervaded his face and muzzle, which to me was always most repellant. Unfortunately, his evil marking notwithstanding, this dog attracted the notice of the judges, and by them was awarded the highest honours attainable, because they said his head was so extraordinarily good in its various developments. It was ex- 
aggerated all over, and so was not a good head. He was both "lippy" and "jowly," his skull was very wide, still proportionate with his muzzle, and he was but little undershot.

However, he, winning prizes, was used very much at stud, and continued, with that perverseness so marked in many instances, to transmit his very defects to his progeny, and any good points he had-well, he kept them to himself. Crown Prince was a straight-hocked dog, and a very moderate mover, nor were his fore-legs and feet nearly so good as they might have been.

The following communication is from one of the leading exhibitors and breeders of mastiffs at the present day, and the opinions expressed therein so thoroughly coincide with my own, that I have not the slightest hesitation in publishing it, however it may grate on the feelings of those who during recent years have tried to produce an abnormal head at the expense of good limbs, lengthy body, and other important attributes:

"There can be little doubt that with the advent of Crown Prince came a new era in the history of the mastiff. In him we had a dog of a very striking personality, not by any means confined to his peculiar and ugly colour. Crown Prince was probably a more compact, shorter-bodied, shorter- 
faced, and more massive-headed mastiff than almost any dog of the race that had preceded him. The novelty of his appearance, it is to be presumed, caused an enormous demand for his services at stud, and it is only to be regretted that mastiff breeders at that time should have so neglected nearly every other dog. Thus we are now placed in the unenviable position of being absolutely compelled to inbreed to an alarming extent or to introduce some other strain with which to invigorate our modern blood. That Crown Prince and Beau together are responsible for the present fashionable type of head is evident, but it is to be feared the former also gave us a lighter eye and a shorter body, as well as those disfiguring straight hocks, which were so prevalent-and are still too often met with-a few years ago. The loss of density or blackness of face markings, too, may also be traced to him.

"But the faults we got from Crown Prince were unquestionably emphasised by the rush upon the dog, to the neglect of almost all others; and had his services been sought a little less exclusively, we might not now have to regret many of the faults of our present dogs-inbreeding having developed them - or that the means of breeding at all are so difficult. 
"In a great number of cases where Crown Prince was probably used to suitable bitches, he proved himself the progenitor of some of our very best mastiffs - best, not only because of successes on the show bench, but because they exhibited his good qualities with few of his bad ones. This was strikingly shown in the case of Dr. Turner's The Lady Isabel, in Mr. T. W. Allen's Montgomery, in Capt. J. L. Piddocke's Toozie, and others.

"One cannot pick up a catalogue of even four or five years ago without noticing how the number of entries in the mastiff classes have fallen off. That this is in any way due to decadence in the mastiff's popularity I do not for a moment believe. Even in so short a period dog shows have enormously increased in number, with the result that exhibitors can now pick their shows, with the almost inevitable result that the classes do not fill so well, although the total number of mastiffs exhibited has possibly decreased but very little. Then the general body of owners still required education in the requisite points, and, pending this, did not hesitate to show their dogs, adding, if not to the quality, to the quantity, and the "tail" of the classes.

"Latterly, whether our mastiffs, as a breed, be better or worse than in the days of Lukey and his 
contemporaries, the general type has become more uniform, and in consequence owners of those dogs which would appear to be mastiff only in colour, have learnt the futility of showing them.

"It is, perhaps, not too much to say that the 'Description of the Mastiff,' issued by the Old English Mastiff Club, and given on another page, has, as a description of a perfect dog, never been approached, and if it were but possible now to produce a mastiff as a living model of the description, we should be able to point to it as deserving of admiration from the fancier, the artist, and from him who keeps his mastiff as companion and friend.

"But there is one point which has no place in the required show points of the mastiff. Still it is, in all dogs, and more especially in a large, powerful creature, of fundamental importance. It is the temper. Now, so long as the owner remain merely the exhibitor, keeping a dog as a machine with which to win prizes, bestowing no pains upon the education of his puppies, or, at most, leaving any tuition in the hands of an indifferent kennelman, so surely will the inherent courage, docility, and beauty of temper of the mastiff gradually become mere history of the past.

"Dog shows unquestionably tend to develop excitability, and if this be fomented by neglect and 
carelessness at home, we must not wonder if the would-be owner of a mastiff requires some further proof of the trustworthiness of the breed than a discussion in the public prints, no matter how much in favour of the dog it may be.

"But, two show-points have some bearing on the question of temper; not that either is any actual indication as to what it may be, although they certainly give an impression with regard to it. The first is the colour of the eye. Is it possible to regard the dog owning a pair of light eyes, glaring out from a black or dark face, without feeling considerable doubt of his amiability? I think not. The second point is the undershot jaw. While this gives an awe-inspiring and imposing character to the head, it destroys all benignity of expression, even to a greater extent than the light eye, and, necessary as I consider the extreme power of a mastiff's under-jaw to be, its strength should lie in its width and depth rather than in its elongation to any great extent beyond the upper jaw. We have seen this extreme development of under-jaw very evident in Mr. T. W. Allen's Montgomery, Mr. W. K. Taunton's Beaufort, Capt. Piddocke's Toozie and Jubilee Beauty, Ogilvie and Lord Clive, and in many others, and I venture to think all these extremely good headed dogs would have been even 
better had they been a little less underhung. It is given in the 'Description of the Mastiff,' that the muzzle is to be blunt, and at a right angle with the upper line of the face; an impossibility if one jaw is to protrude so far beyond the other.

"When good qualities are exaggerated-for we can have too much of a good thing-or become altogether ignored, it is necessary to make allusion thereto. Mere show points are for the consideration of the fancier alone, perhaps, but even he should insist upon soundness of limb and development of those parts indicative of power, activity, and a good constitution. Many of our mastiffs are not all they should be in forelegs and feet, many are narrow-breasted and contracted in the ribs, evidence of a bad constitution, and many more haveweak stifles, weak hocks, and thighs almost devoid of muscle.

"The actual length of the face is of very small importance in comparison with its strength, i.e., breadth, depth and bluntness, and it is in respect of this strength present-day breeders assert that the mastiffs of some twenty years ago failed. In the effort to remedy this, the foreface has become shortened, for I cannot believe that we have our present type as the outcome of a sole desire to shorten, merely for the sake of shortening, a long muzzle which was already perfect in other respects. 
"Since the time of Crown Prince we have had many splendid mastiffs, but for good all-round merit there has been nothing to excel Beaufort and Minting of the one sex, or Cambrian Princess and Mr. C. C. Rice's Frigga Secunda of the other. Possessing, as he did, not the smallest drop of Crown Prince's blood, it was to be regretted when Minting left this country for America, and even his brother, Charley Wood, who, though neither so good nor so famous, would have proved of immense service to breeders, had he been left us.

"Dr. Sidney Turner's, afterwards the Rev. H. K. van Doorne's, Orlando, if not by any means the most perfect of Crown Prince's progeny, was perhaps the most conspicuous, and he has fortunately given us many good mastiffs with a large share of their sire's good points, and with but little sign of his deplorable hind quarters. The best of these were Mr. W. K. Taunton's Griselda, and Mr. C. C. Rice's Frigga, whilst others who did, or did not, excel in head points, conclusively proved Orlando to have been capable of begetting excellent limbs on his stock, a case in point being Mrs. Lee's Holda. Orlando's brother, a later litter, and $\mathrm{Mr}$. W. K. Taunton's Hotspur, will also be remembered as the sire of many winners, notably Constable and Carshalton Prince. 
"Of late years, Beaufort stands out as the sire of dogs of good all-round excellence. Among the first of his stock was Wodan, so remarkable for his extreme shortness of face and great length of body; then we know Beaufort as sire of Lord Stafford, Sir Stafford, Lady Florida, Seabreeze, Isolde, Ayrshire, and others, as well as of many in the United States, such as Ilford Lady Coleus, Lady Phyllis, Beaufort's Black Prince, \&c.

"A noteworthy dog was Mr. R. Cook's Ilford Chancellor, very noticeable for an extraordinary development of dew-lap, a disfigurement which probably did more to bring about his defeats by Beaufort than anything else. Mr. E. Nichols' Victor Hugo, another dog of great excellence, and pretty much free from most of the modern bad qualities, is illustrated in 'Dogs of the British Isles.' He took a high position, without ever attaining the title of 'Champion,' and from him we get Jubilee Beauty and Mr. Z. Walker's Stentor. The Rev. H. K. E. van Doorne's Jack Thyr, another mastiff who gained a high reputation on the show bench, though a terribly bad mover when out at exercise, has, however, given us nothing better than Mr. Cook's, now Mr. Higgs', Ilford County Member and Capt. Piddocke's Don Juan II. The career of the last-named was very short, and the 
name of Sir Stafford will probably be remembered more as the sire of Frigga Secunda and Cardinal Beaufort than as a show dog. Nor must Capt. Piddocke's Ogilvie be forgotten, for he is probably the best brindled mastiff ever exhibited, and as a sire he has already made his mark, so desirable a specimen of the race as Brampton Beauty owing paternity to him. And a word must be said, too, for Montgomery, the sire of the good headed but bad limbed Kaiser Frederic, Duke Rollo, and Mr. W. Norman Higgs' admirable bitch Coombe Baroness. But during the past two years there has been a lull in the production of mastiffs of marked excellence, the breeding seasons having been disastrous in the extreme.

"Since the days when Crown Prince, Cambrian Princess, H.M. King Canute and Maximillian, made Mr. H. G. Woolmore's name as a breeder, Dr. J. Sidney Turner, Mr. W. K. Taunton, the Rev. H. K. E. van Doorice, Capt. Piddocke, and Mr. Cook have been the most successful exhibitors, although others, including Mr. A. Andrews of Stafford, have done much in producing admirable specimens, nor must the name of Mr. J. Hutching, of Exeter, be omitted. But, on the other hand, such old fanciers as Mr. E. Nichols and Mr. Mark Beaufoy, the breeder of Beau, appear to have retired, and their places will be hard to fill. 
"Since its foundation in I883, the Old English Mastiff Club has never flagged in its efforts on behalf of the mastiff, and the respect it commands, both in England and America, proves its endeavours have been appreciated. In addition to its other work, and the money prizes it offers at shows, there is a Challenge Cup for each sex for competition among its members in England, and two others for competition in America. Nor are breeders, as distinct from exhibitors, forgotten, there being Challenge Prizes for the breeders winning them a certain number of times with dogs under two years of age. Lastly, during the present year, a Challenge Cup for brindle mastiffs has been instituted, so that admirers of that colour lack nothing in the way of encouragement."

The following are the descriptions drawn up by the Mastiff Club, and alluded to earlier on.

"General Character and Symmetry (Value io). - Large, massive, powerful, symmetrical and wellknit frame. A combination of grandeur and good nature, courage, and docility.

" General Description of Head.-In general outline, giving a square appearance when viewed from any point. Breadth greatly to be desired, and should be in ratio to length of the whole head and face as 2 to 3 . 
"General Description of Body (Height and Substance) Value ro.-Massive, broad, deep, long, powerfully built, on legs wide apart and squarely set. Muscles sharply defined. Size a great desideratum, if combined with quality. Height and substance important if both points are proportionately combined.

"Skull (Value I2).-Broad between the ears, forehead flat, but wrinkled when attention is excited. Brows (superciliary ridges) slightly raised. Muscles of the temples and cheeks (temporal and masseter) well developed. Arch across the skull of a rounded, flattened curve, with a depression up the centre of the forehead from the medium line between the eyes, to half way up the sagittal suture.

"Face or Muzzle (Value i 8).--Short, broad under the eyes, and keeping nearly parallel in width to the end of the nose; truncated, i.e., blunt and cut off square, thus forming a right angle with the upper line of the face, of great depth from the point of the nose to under jaw. Under-jaw broad to the end; canine teeth healthy, powerful, and wide apart ; incisors level, or the lower projecting beyord the upper, but never sufficiently so as to become visible when the mouth is closed. Nose broad, with widely spreading nostrils when viewed from the front; flat (not pointed nor turned up) in profile. 
Lips diverging at obtuse angles with the septum, and slightly pendulous, so as to show a square profile. Length of muzzle to whole head and face as I to 3. Circumference of muzzle (measured midway between the eyes and nose) to that of the head (measured before the ears) as 3 to 5 .

"Ears (Value 4).-Small, thin to the touch, wide apart, set on at the highest points of the sides of the skull, so as to continue the outline across the summit, and lying flat and close to the cheeks when in repose.

"Eyes (Value 6).-Small, wide apart, divided by at least the space of two eyes. The stop between the eyes well marked, but not too abrupt. Colour hazel-brown, the darker the better, showing no haw.

"Chest and Ribs (Value 8). - Neck, slightly arched, moderately long, very muscular, and measuring in circumference about one or two inches less than the skull before the ears. Chest, wide, deep, and well let down between the fore-legs. Ribs arched and well rounded. False ribs deep and well set back to the hips. Girth should be one-third more than the height at the shoulder. Shoulder and Arm, slightly sloping, heavy and muscular.

"Fore Legs and Feet (Value 6).--Legs straight, strong, and set wide apart; bones very large. 
Elbows square. Pasterns upright. Feet large and round. Toes well arched up. Nails black.

"Back, Loins, and Flanks (Value 8).-Back and loins wide and muscular; flat and very wide in a bitch, slightly arched in a dog. Great depth of flanks.

"Hind Legs and Feet (Value Io).-Hind-quarters broad, wide and muscular, with well developed second thighs, hocks bent, wide apart, and quite squarely set when standing or walking. Feet round.

"Tail (Value 3).--Put on high up, and reaching to the hocks, or a little below them, wide at its root and tapering to the end, hanging straight in repose, but forming a curve, with the end pointing upwards, but not over the back, when the dog is excited.

"Coat.-Colour (Value 5).-Coat short and close lying, but not too fine over the shoulders, neck, and back. Colour, apricot or silver-fawn, or dark fawnbrindle. In any case, muzzle, ears, and nose should be black, with black round the orbits, and extending upwards between them."

The executive of the Mastiff Club have not in their description issued any numerical scale of points, evidently believing - as so many others dothe uselessness of figures in arriving at the good, or bad, or indifferent qualities of any dog. However, there are some individuals who would apply figures 
to anything and to everything; so to satisfy them, and to make the description of the mastiff uniform with that of other dogs described in the previous volume, the following scale has been compiled:

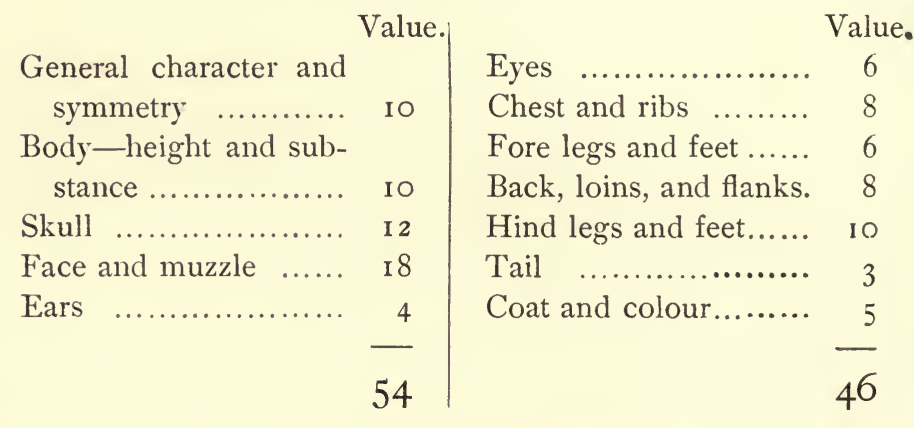

\section{Grand Total 100.}

Weight of a dog, from $155 \mathrm{lb}$. to $175 \mathrm{lb}$; of a bitch, from i 4 olb. to $160 \mathrm{lb}$. 



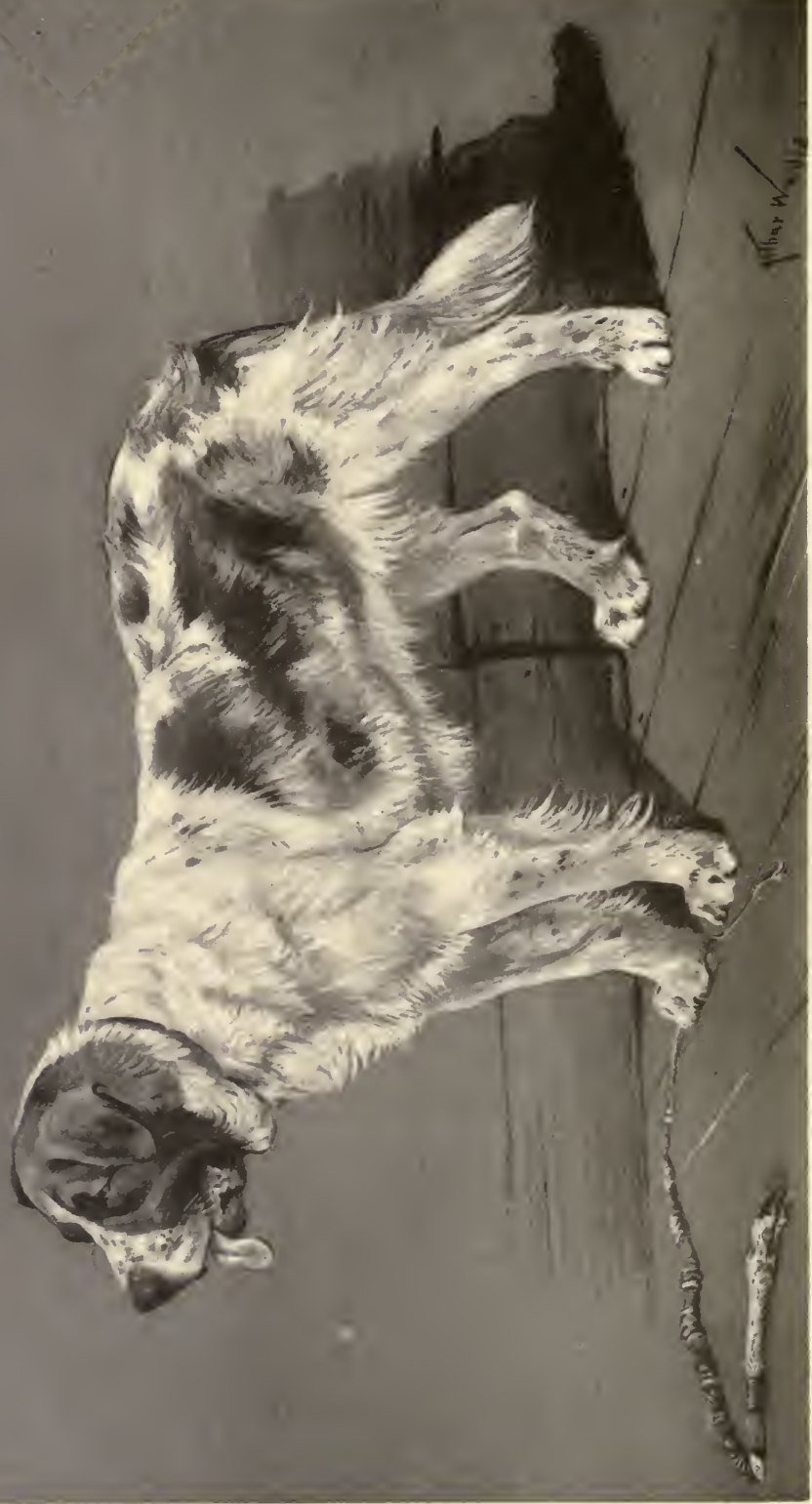




\section{CHAPTER II. \\ THE ST. BERNARD.}

No dog ever appealed more to the kindly instincts of humanity than the St. Bernard. Not his rich chesnut or tawny colour with dark facings and white collar and blaze, nor his kindly benevolent countenance and immense size and power, gave him his popularity. He won that on other "fields" than the artificial ones of dogs shows. He earned his laurels and his popularity on the mountains of Switzerland. Tourists had talked of his intelligence, travellers had written stories of how he saved the lives of benighted travellers overcome by snowstorms. The St. Bernard was a hero in imagination and in anticipation, long before he was seen in this country; and when he was seen, his beauty and dignity at once made him master of the situation.

Some people had called him an Alpine mastiffa bloodhound; others had termed him a mongrelthe consensus of opinion was in favour of his nomenclature being after that hospice of St. Bernard 
in the Alps, where the monks had bred and reared the intelligent creature, and had trained him to go out in the snowstorms and seek for and find any poor traveller whose strength had failed him, and who might lay beneath a snow wreath midway between life and death. What schoolboy has not heard of Barry, the wonderful dog of St. Bernard, who in his time had been the means of saving the lives of some fifteen persons, though the number varies according to the imagination of the narrator, and thus is generally, but incorrectly, given as about forty. However, Barry was the most celebrated dog these monks ever possessed, and during fourteen years (he was fifteen when he died) went out on to the mountains and sought for the strickendown wayfarer. It has been said that the poor dog met his end by one whom he sought to rescue, taking him for a wolf and killing him. Another story is as follows:

In the winter of 1816 , we are told that a Piedmontese courier arrived at the Hospice on a very stormy day, intent on proceeding on his journey to the village of St. Pierre, in the vale below, and where his family were. The monks attempted to dissuade him from leaving until the storm had abated, but he preferred going forward, so, with two guides and a couple of dogs, he set out down the 
mountain. At the village the family of the man had become alarmed at his absence, and ascended the mountain in the hope of assisting him home. Two terrific avalanches at that time fell, and, rolling down from where the snows had accumulated for years, overwhelmed, first the courier, his guides, and the dogs, and continuing their course, swept the man's family to destruction-and it is said Barry was one of the dogs that met so untimely an end.

Though the monks have had their dogs for many years-how many has not yet been traced, but their monastery was founded in 962-as British subjects St. Bernards are but a modern institution. Perhaps they were originally at the Hospice for protection of person and property, as the following extract from an old English newspaper will testify:"In March, I786, the convent of Sion, on the borders of Switzerland, was attacked by twenty-four villains who demanded the treasure thereof. The monks replied that their rents were ill-paid, and that at present they had very little stock, but they would show them where it was. Accordingly the robbers were shown upstairs where it was said to be, when, opening the door where the bloodhounds (?) were and giving them the word, they fell instantly upon the villains and tore some of them to pieces. The others, attempting to fly, were pursued and 
taken accordingly. These dogs are kept therefore for the preservation of the convent, and to find dead bodies in the snow; for many perish in attempting to cross the Alps, whose bodies are found by these dogs and receive decent interment."

I think the above quotation particularly interesting, especially as it is about the time when we appear to have little knowledge of the St. Bernard. It would be by no means difficult to bring about such a change in the duties of a hound, who, when seeking the dead bodies of travellers, would not unfrequently discover other travellers who had not quite succumbed to the rigours of an Alpine storm, and so be the means of their preservation. Such cases occurring once or twice, and the kind-hearted monks would not be unwilling to discern that some refreshment placed around the neck of the dog would be seen and gratefully appreciated by the poor man who required such assistance.

It has been said that it was not until I8I5 that the first St. Bernard was imported to this country, this being a specimen that went to Leasowe Castle, in Cheshire, the seat of the Cust family. Many years, however, passed over before the great dog began to force himself -upon the public. Landseer painted him on one of his canvasses, but this great artist called him the Alpine mastiff. Still, even 
then, he was known as the St. Bernard; for I have an extract from a magazine dated 1843 , in which it is said that a St. Bernard puppy, born in London, endeavoured during a severe winter to track the footsteps in the snow just as his parents might have done years before on the Alps, and what made this still more strange was the fact that until the snow fell the puppy had never before attempted anything of the kind.

Then Albert Smith, a celebrated entertainer a generation ago, who pleased our fathers, and ourselves in our childhood with his interesting lectures and panoramas, after one of his visits to the continent, returned with a couple of St. Bernard dogs from the Hospice. These he made a most attractive feature of his already pleasant show, introducing them in connection with Mont Blanc. This would be about 1850 .

Still the dog of the Hospice did not attain popularity. The country was not at that time educated up to the pitch of dog shows; railway communication was not then what it is now, and, moreover, it is quite likely that had the general public wanted St. Bernards, they could not have obtained them in sufficient numbers to satisfy the demand. Canine history tells us that a distemper of a virulent character attacked the Hospice dogs about 
fifty or sixty years ago, and killed all with the exception of one animal. Again, earlier than this, an avalanche it is said proved almost equally fatal in its effects. In $185^{2}$ "Idstone" informs us that there were but three dogs at the Hospice, although seven or eight others were kept in some of the neighbouring villages. The latter must have been always the case, and one cannot believe that at any time during the history of this dog it was so near extermination that but a single specimen remained. It is a well authenticated fact, although one that has hitherto been almost, or entirely, overlooked by writers on the St. Bernard, that dogs of the race have from time out of mind been used in Switzerland and on its borders as beasts of burden.

No doubt some of the villagers who did business with the monks were dog lovers, and would now and then beg or purchase a puppy, and from youngsters so obtained, and trained to draw light handy carts, quite as much as from those brought up in the Hospice, our present race must have sprung. But old Barry was not nearly so big a dog as our best modern specimens, possibly he might be more active than some of them; nor was his colour so bright, nor were his markings so exact and regular as are looked for to-day. Barry was a dullish brindle and white, or white and brindle in 
hue, a pleasant-looking, smooth-coated dog, with nice character, I have been told, but a pigmy in comparison with the giants of our times. Some modern champions, with their thick, shaggy coats, twisted hind legs and huge heads, would, I am afraid, make but sorry headway through the snow, even though they might possess "double dew claws," with which nature was said to have provided them in order that they should not sink in the snowdrifts. Happily the latter fallacy has been exploded, and neither the absence of or presence of such abnormal excrescences has the slightest weight with a judge of St. Bernards at the present day. As a fact, the Swiss monks prefer the smooth or short-coated dogs, for reasons which are sufficiently obvious.

About thirty years it is since this dog began to obtain popularity in this country. A year or two before that time, specimens had occasionally appeared at our earlier dog shows, in the "variety" classes mostly, but in 1863 there was a canine exhibition at Cremorne Gardens, and here a section was specially provided for the novel variety, and it had an entry of fifteen. Lord Garvagh was the judge, and he gave the first prize to the Rev. N. Bates's Monk - an imported dog, said at the time, as all imported dogs then were, to be descended from the celebrated Barry. The Field report of the show 
said that both this dog and the second prize winner were of the Newfoundland type, but being assured by the judge that they were such as the monks had, he said no more on the matter. The writer of the report evidently did not consider them the genuine article. However, this was the first class ever provided for St. Bernards at a dog show in the British Isles, and it was not until i 866 that the Birmingham Council followed the good example. Prior to this date, the exhibitors at the National show had to put their St. Bernards in the variety class, where the above-named Monk won in 1862, and Mr. Macdona's celebrated $\operatorname{dog}$ Tell, of great fame at that time and later, in 1865 .

The first special class at Birmingham had an entry of thirteen; here again Tell won, a kennel companion named Bernard, second; and by this time Mr. Macdona had come quite to the front as the reintroducer and actual populariser of this noble variety. In 1868 the variety had progressed to such an extent that the management at Curzon Hall provided two classes for them, viz., rough and smooth, and the latter had an entry of eighteen, the former one of eight only, both first prizes being won by Mr. Macdona. Then in I869, at the Islington show, held at Laycock's Dairy-yard, the first big thing of the kind the present writer ever attended, two classes 
were again provided, and once more did the Hilbre House kennels furnish the leading winners, the smooth dog Monarque making his début on this occasion, taking an easy first, with his kennel companions Victor and Jungfrau second and third. Tell won in the other class, with Sir C. Islam's Leo second, and Mr. Macdona's Hedwig third. It will be seen, such advances had the variety made, that in all six prizes were given. So came about the popularisation of the St. Bernard, and, as the saying goes, he has never looked behind him since -gone on prospering rather, for where at that time one good enough to win at a big show would be worth fifty or one hundred pounds, to-day one with similar ability would, perhaps, command three or four times that sum. For as well as being the biggest and handsomest of the canine race, he is the most valuable.

Much has of late been written as to the deterioration of the mastiff, owing to its so-called admirers breeding them for certain points to an exaggeration, but such cannot with fairness be said with regard to the St. Bernard. Whether the latter is easier to breed true to type than other large varieties of the canine race it is difficult to say, but there is no doubt that there are more good St. Bernards to be found now in 1893 than there are of any other big dog. 
Monarque, Tell, and one or two others stood well ahead in their day. Then came Mr. Murchison's Thor, Mr. F. Gresham's Hector, The Shah, and Abbess, Miss Aglionby's Jura, one of the very best shortcoated bitches I ever saw, followed by Mr. Macdona's Bayard; all of which in reality stood head and shoulders above other competitors. Menthon-a big black and tan ugly dog. quite wrong according to prevailing ideas, maybe right according to the style and character of a hundred years ago, resembling a half-bred bloodhound or Thibetan mastiff-did a considerable amount of winning at the earlier shows, but happily, if he was used at stud at all, he has not passed down his defects to the present generation.

Mr. F. Gresham, at Shefford, in Bedfordshire, and the late Mr. J. H. Murchison, following Mr. Macdona, gave greatest attention to breeding and importing choice specimens. At one period, about 1874, the former with such animals as Monk, Abbess, Hector, The Shah, Dagmar and Othman, possessed a kennel of St. Bernards which up to that time had not been equalled. At one of the Alexandra Palace shows, the Shefford strain made a record by winning first and second prizes in open rough dogs, the same in bitches and in smooth dogs, first honours in smooth bitches, all three 
prizes in puppies, as well as both cups that were offered.

Not long after this time, about i882, Mr. R. Thornton introduced a beautiful smooth bitch, a brindle with white markings, called Leila, and for a year or so she was the best of her race appearing in public. Then longing eyes were cast at her from the other side of the Atlantic, and she with $\mathrm{Mr}$. S. W. Smith's Duke of Leeds and two others of less note were sold for $£ 800$, this being about the first occasion upon which our American cousins opened their pockets to take from us some of our best show dogs.

Without much interlude we are brought right up to the institution of the St. Bernard Club in I882, when the variety obtained another fillip, and two years later the Rev. Arthur Carter introduced his immense puppy Plinlimmon, the biggest and handsomest dog ever seen up to that time. So it was considered such things had reached a climax, and Plinlimmon, who was bred by Mr. W. M. Pothecary, of Lymm, Cheshire, would be the dog of the century. Proving the chief attraction at all shows where he appeared, he reclined in dignity on his bench, he held levees throughout the day, he gave his paw to the ladies, he beamed pleasantly on the children. His colour was handsome and bright, he 
was as active as a kitten, had not too much coat, measured $33 \frac{1}{2}$ inches at the shoulders, and weighed 2 Iolb. when not too fat. Until i 886, Plinlimmon had not suffered defeat since arriving at maturity. However, in the autumn of that year, he had his colours lowered by a much smaller dog, Mr. King-Patten's Prince Battenberg, who, at Birmingham, was placed over the giant for the special cup-a decision that astounded his many admirers. Still, Mr. Patten's dog was a very perfect specimen so far as he went, and although his head was more typical than that of Plinlimmon, alongside the latter Prince appeared very small. He was a great favourite with some judges.

For such a dog as Plinlimmon there was a prompt demand. Mr. Carter was induced to sell him, then he became the property of different individuals. Mr. J. F. Smith, Sheffield, had him for a time, so had Mr. S. W. Smith, Leeds, and the latter sold him to an American actor, now deceased, Mr. J. K. Emmott, for something like $£ 800$. Poor Plinlimmon was transferred from the boards of the bench to those of the theatre, and he died in the States only two years ago, leaving however, many of his excellences behind him stamped upon the features of a most numerous progeny. There was but one fault to find with "Plin," as his friends loved to call him, 
he was rather too long in his face and skull; still a dog with but one fault must needs be almost perfection. Mr. J. F. Smith had also Save, an extraordinarily good dog, about this period; Bayard, who had also become his property, a grand dog in his day, was now in the sere and yellow; Mr. J. Royle had another excellent specimen in Duke of Marlborough; the giant Rector, Mr. S. W. Smith's, had gone to America, but equally good or better than any of them remained at home.

At the time Plinlimmon reigned in the longcoated division, a short-haired prototype of his held sway in the section to which he belonged. This was the brindled and white Guide-which Mr. H. I. Betterton had imported from Switzerland where the dog had been bred by M. H. H. Dür-by Leon from Belline. From the time of the importation of Guide and his half-sister Sans Peur, also bred by M. H. H. Dür, may be traced the great improvement made amongst smooth-coated St. Bernards in this country. In the Stud Book Sans Peur's pedigree is given as unknown, but she was by $M$. Siegenthaler's Barry from Belline, who was by Burki's Barry II.-M. Gurtner's Lola, by M. Egger's Barry A.-Diana A.

Mr. J. F. Smith, of Sheffield, owned an extraordinary collection of smooth-coated dogs, and his 
namesake-not relative-Mr. S. W. Smith, at Leeds, was almost equally strong in the rough-coated division, as he is at the time I write. Other admirers were likewise coming to the front, if they had not already done so. Mr. Norris-Elye, Mr. DuerdinDutton, Mr. L. Oppenheim, Mr. Hedley Chapman, Mr. H. I. Betterton, Mr. G. W. Marsden, jun., Mr. A. J. Gosling, Mr. J. W. Rutherglen, Mr. HughesHughes, Miss Campbell, Rev. R. T. Thornton, Mr. W. R. Reid, Mr. Marshall, Mr. T. Thorburn, Mr. H. G. Sweet, Dr. Inman, \&c., but it was not to one of them we were to be indebted for the next wonder in canine form.

In $1887 \mathrm{Mr}$. T. H. Green, who then resided at Wallasey, near Birkenhead, not far removed from where Mr. Macdona's champions had, twenty years before, rolled on the sands and dabbled in the sea round about Hilbre Rectory, introduced a dog called Sir Bedivere, who was by Nero III. -Bena. Standing as high as Plinlimmon, equally heavy and quite as good in body, legs, feet, and general character, Sir Bedivere possessed a perfect head, so for the two years that he remained with us. he took all before him whenever he competed in the show ring. His markings and his colour were superb, and although other good dogs have been brought out since, I fancy that Sir Bedivere's equal 



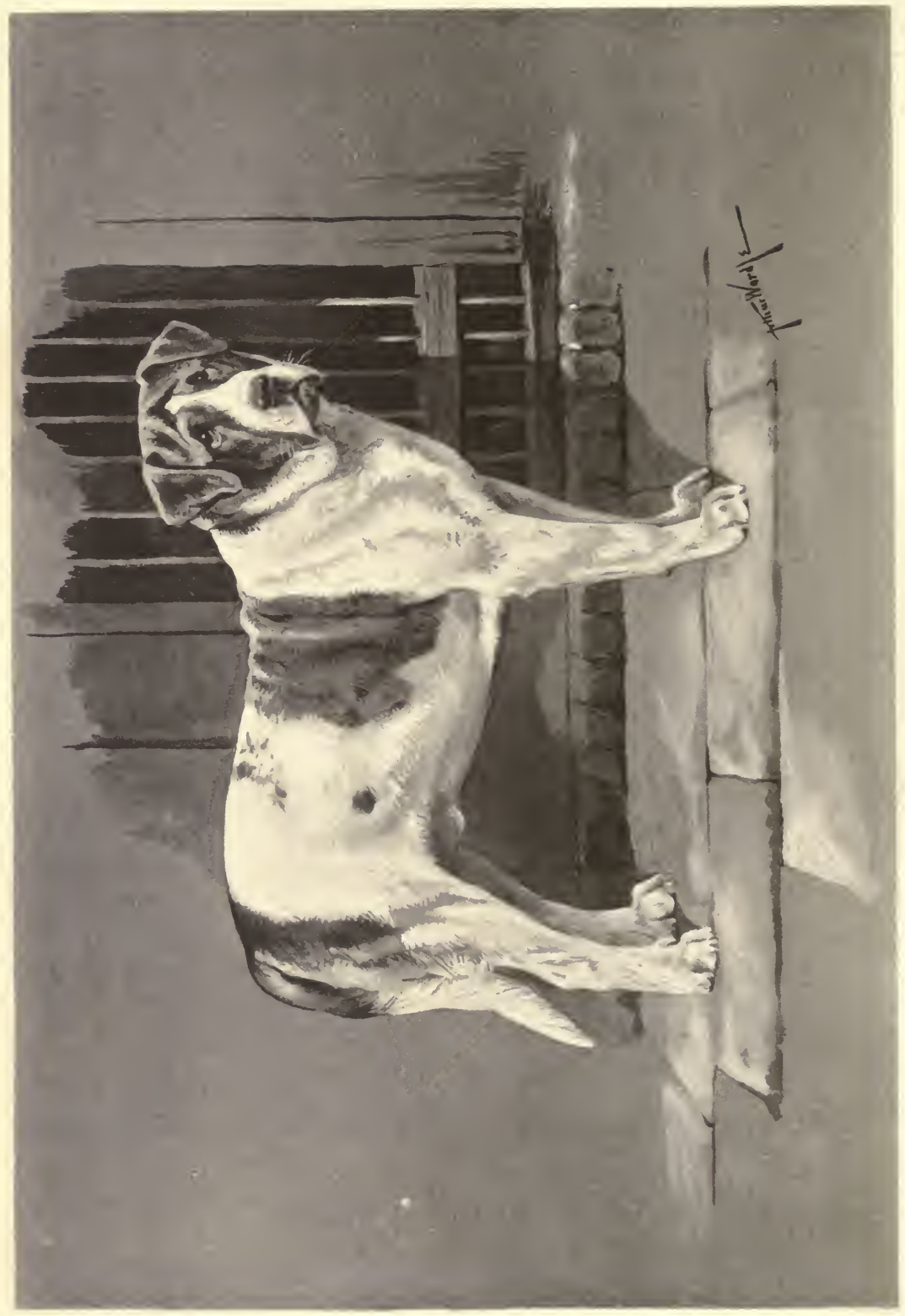


will not be found in a hurry. $\mathrm{He}$ was never defeated, and won the Club challenge cup on several occasions. Mr. Green repeatedly refused large offers for his favourite $\mathrm{dog}$, but in the end was tempted, and, for a consideration of it is said $E_{1} 300$, Sir Bedivere went across the Atlantic, into the kennels of Mr. E. B. Sears, of Melrose, U.S.A., who eventually sold him to Mr. W. C. Reick, of New York, in whose kennels he continued his successes, although one of the American judges placed him below Princess Florence at the New York Show in the spring of 1893 . The same year Sir Bedivere was sold to Mr. C. A. Pratt, Arkansas.

Following him came Watch, a dog Mr. Betterton bred by mating Guide with Sans Peur, also an importation from Switzerland. Almost equally as heavy a dog, Watch did not look so big as Sir Bedivere, nor was he generally so well made in his body, nor so perfect on both fore and hind legs, nor in colour. Watch, however, was as near perfection as possible in head and expression, and in this respect was equally as good as his more handsomely - marked opponent. Watch, too, was destined for America, for, after becoming the property of Mr. J. F. Smith, he was sent over to the States for about 5000 dollars.

As a fact, our American cousins have spent large E 2 
sums of money on some of our best St. Bernards, but whether the climate of the States does not suit them, or the living is different, or whatever be the cause, these imported dogs never do well in their new home, where many have died long before their time ought to have come. Another of our best specimens, Princess Florence, an immense bitch, has been amongst their latest purchases, and it is to be hoped that she will do more good to her strain than have others of her race. Sir Bedivere weighed 2 I $2 \mathrm{lb}$., was $33 \frac{1}{2}$ inches high at the shoulder, but big as he was and all round the better dog, he never appeared to so fill the eye as the giant of his race as Plinlimmon was in the habit of doing.

Whilst alluding to big dogs, mention may be made of Mr. Shillcock's Lord Bute, said to be the one giant of his breed. He might stand a quarter of an inch higher than Plinlimmon, but he was not nearly so heavy a dog, and withal but a moderate specimen. $\mathrm{He}$, too, went to America, with a stated weight of about 2oolb., which, on arrival at his destination, came to be increased about ten per cent. He has, however, a very excellent son in Young Bute, once owned by Mr. S. W. Smith, of Leeds. This dog likewise went to America, his purchaser being Mr. W. Reick, of New York, who had, at the time of writing this, the finest 
kennel of St. Bernards, probably, in the world. It had included such dogs as Sir Bedivere, Young Bute, Princess Florence, and Marvel.

As a fact, in the present year, I 893, there are several very excellent St. Bernards now or recently appearing at our shows, to wit-Mr. Duerdin-Dutton's Starboard and Binnacle (Pegotty also should be mentioned, but she is now rather old); Mr. NorrisElye's Alta Bella, Bellegarde, and Beautiful Abbess; Mr. S. W. Smith's Le Prince, who made such a successful début at Birkenhead, in the autumn of 1893, and again won all that was to be obtained at Edinburgh; Mr. T. Shillcock's Duke of Maplecroft, a son of Marvel and Princess Florence, his Lord Rosebery; Mr. J. F. Smith's Siegmund's Czar, recently imported from Switzerland; Mr. Lewis's Colonel V., Dr. Inman's Winona, Rev. R. T. Thornton's Andromeda and Albula-all of the rough-coated variety. Nor must we forget to mention that big and good all-round dog, Mr. Royle's Lord Douglas, who made a most favourable first appearance at the Kennel Club Show in I893, where he won several first prizes and came reserve for the challenge cup.

Amongst the best smooths, in addition to those already mentioned, are Mr. J. F. Smith's Keeper, Gondola, and a young dog named Marengo, by 
Keeper-Altruda, which he brought out at Darlington, where he defeated his sire Keeper and Argonaut for the special cup, but shortly after was purchased by Mr. Paterson, of Glasgow, who also bought Lola IV. and Sans Peur; Mr. G. W. Marsden's Sans Reproche and Barrie; Rev. R. T. Thornton's Triton, recently bought from Mr. J. F. Smith; Mr. West-Little's promising puppy Tyrconnel, who is having such a successful career in Ireland; and Mr. Rutherglen's Argonaut. There is one dog, however, which, although useless on the show bench on account of his injured tail, must not be forgotten, and that is Capt. Hargreaves' rough-coated Sir Hereward (a litter brother to Young Bute), who undoubtedly stands high as a stud dog, and, although small in size, is probably as typical a St. Bernard as we possess.

As to the rough and smooth varieties, both repeatedly appear in the same litter, a notable instance of the kind happening when Bena produced Sir Bedivere, for at the same time there was another puppy, afterwards called Baron Wallasey, which was a thoroughly smooth-coated specimen, and took many prizes as such. The historical Barry was a smooth-coated dog, and the St. Bernardine monks prefer the smooth variety, for a short coat can be quite as protective as a long one, and 
would not be nearly so likely to be clogged up with snow as the latter.

There is a painting by a German artist named Specht, of four St. Bernards on the mountains; all are of the short-coated variety and excellent specimens too. Possibly why we in England have paid greater attention to the long-haired dogs is because of their greater beauty. Moreover, as a rule, almost all the best short-haired dogs have been and are white and brindle, a colour not nearly so pleasant as the rich red chesnut with white collar and blaze and dark shadings, which we have made fashionable in the rough-coated variety. It is said that the collar and the "blaze," the latter that white mark down the face from the occiput to the nose, are particularly valuable, as being representative of certain of the vestments worn by the order from which the dogs take their name. This may be so or not, probably not, for the monks themselves make no such acknowledgment, and they ought to know; but so far as beauty is concerned, no doubt dogs so marked are much the handsomer, and in this country are not considered perfect without that "blaze" and " collar."

Careful rearing and the best of food during his puppyhood, have added considerably to the St. Bernard's stature, and a full-grown dog of $200 \mathrm{lb}$. 
weight is not now considered more extraordinary than was one of $160 l b$. weight a quarter of a century ago; and, whatever was once the case, there is no doubt that the race of St. Bernards is the biggest variety of dog known at the present day.

Mr. F. Gresham kindly furnishes the following :

"To anyone who has made a study of the St. Bernard since it has become naturalised in England, it must be apparent that the smooth-coated varietyor it would be, perhaps, more correct to say shortcoated variety-is the more purely-bred animal. In support of this we have only to go back to the institution of dog shows, when the rough-coated champion Tell and the smooth-coated champion Monarque were the most perfect representatives of their breed in this country, to see that at that time the smooth variety was much nearer the standard of perfection than the rough, and, as already stated, at some of the earlier shows more smooth than rough dogs were benched. Were Tell to be brought into competition with such dogs as Sir Bedivere in the present day, he would cut but a sorry figure; whereas Monarque, even in such company as that of Watch, Keeper, or Triton, would have been able, if not to win, to make a good fight. Following on the same lines, the rough- 
coated Thor, who has done so much towards building up the kennels of rough-coated St. Bernards here, and from whom are descended almost all the best of the variety, was very deficient in the most important properties, and on the bench was altogether a failure, even amongst the dogs that existed when he was alive. Furthermore, we have it on the best authority that short-coated St. Bernards are more highly prized than rough-coated at the Hospice of St. Bernard, and, moreover, are thought more of throughout Switzerland, the land of their birth, where there are at least a dozen good smooths to one rough. From these facts the conclusion may be arrived at that the rough-coated St. Bernard of to-day is purely a manufactured animal, whilst the smooth is a reproduction of the original St. Bernard, altered only in a slight degree as regards the texture of the coat.

"From the first the rough-coated St. Bernard has been the more popular in England, notwithstanding that it is looked upon more or less as a mongrel in Switzerland; but it must be remembered that here usefulness has not been a consideration, and it has been the object of breeders to produce the most ornamental animal. The result is, that in this connection some magnificent specimens of the rough type have been bred, and there is now 
no necessity to seek for reinforcements from the home of the breed. Not so, however, with the smooth, which until recently have been more neglected, and only came into special favour when a powerful contingent was a few years ago sent over from Switzerland, from which almost all the best that we now possess have been produced. It is a notable fact that, although many first-class smooth-coated St. Bernards have been imported to this country, there is not a single instance of a rough specimen of really high quality ever having been purchased from breeders on the Continent.

"Notwithstanding the giant strides that have been made in the improvement of the rough-coated St. Bernard, as far as height is concerned it is a debateable point whether it has not been obtained at the expense of other more desirable properties. Great height without proportionate massiveness of build is generally accompanied by a weak constitution. To this may be attributed the number of "cripples" that are to be seen on the show bench; the very tall dogs are all, without exception, narrow and weak in their hind quarters. It is a point in favour of a horse to go well from you, which means that it has wide hips and well let-down quarters; the same applies to St. Bernards, and, until they can be bred with all points in proportion, the extreme height is 
a disadvantage rather than not, and accounts for so many prize dogs not being able, as it were, 'to carry their own weight.' Plinlimmon and Sir Bedivere stood over Hector, who was the star of his day fifteen or twenty years ago, quite two inches; but Hector was at least three inches wider in hips and quarters, and so much better and stronger in the hind quarters."

During the present summer (I893) Mr. J. F. Smith, of Norfolk Lodge, Sheffield, who still owns, and has owned, some of our very best St. Bernards, took a tour into Switzerland in order to see his favourite dogs as they are in their native country. With the greatest kindness Mr. Smith put into pen and ink what he saw of the dogs there, and his impressions thereon, handing me the result for publication. I need scarcely say that this communication is by far the most complete, interesting, and practical account of the St. Bernard in Switzerland that has yet been printed. Let Mr. Smith tell the story of his pleasant tour in his own words :

"For the last fifteen years it has been my wish to visit Switzerland and the North of Italy with the view of seeing for myself the home of the St. Bernard dog, a breed which I have kept and taken great interest in for many years. However, something or other continually turned up to prevent my 
taking the tour till this year, when, to my delight, I was able to start for the land of the Switzers on the I $5^{\text {th }}$ of June, I 893 .

"Leaving home on the $15^{\text {th }}$ June, I travelled via Calais and Paris to Lausanne, where I saw several St. Bernards, both rough and smooth coated, most of them very poor specimens.

"On the I gth I went to Berne, and the first visit I paid there was to M. H. Schumacher's. I found him at home, and he took me to see the only two St. Bernards he had, a smooth dog and a rough bitch; the former was a very tall animal, fully 34 inches high at the shoulder, symmetrical in shape, fair in bone, but sadly weak in muzzle. The rough bitch was only ten months old, handsome in colour and markings, though too small and weedy. M. Schumacher informed me that they had lost a great many of their best dogs during the last twelve months from influenza, but he said I should find a very good dog at Worb, a village about nine miles from Berne.

"After dinner at the hotel, I started for Worb at seven p.m. My driver, quite a jolly fellow, spoke English well, and enlivened the journey by giving me some interesting accounts of the villages we passed through. It was nearly dark when we arrived at Worb (Worb is supposed to be the 
richest village in Switzerland), and found the owner of the $\operatorname{dog}$ in question (M. Fritz Lienhardt) was not at home, but he returned before we left. Mme. Lienhardt was kind enough to show me the dogs, or rather a smooth dog and a bitch. The dog, who had taken premier prize at Berne, is four years old, handsomely marked, patched very dark orange and white, with black shadings, tall, good in bone, fair in head, but hardly deep enough in muzzle. The bitch we saw here was typical in colour, orange and white patched, good in head, but she was too small. We reached Berne about i I.I5 p.m.

"The following morning, June $25^{\text {th, was the }}$ market day in Berne, and our driver of the previous day came to the hotel shortly after breakfast and said he should be glad to show me round the town. I was very glad of his service, as he knew most of the country people. We saw a great number of St. Bernards, both rough and smooth, in the market place lying down beside the carts which they had drawn to the market (the carts contained vegetables, fruit, flowers, cheese, butter, eggs, \&c.). Some of the vehicles were drawn by a couple of dogs with a man or woman between them to guide the shafts and prevent a spill or turnover. Other carts were drawn by only one dog. These dogs were a mixed lot, most of them St. Bernards; many were 
but indifferent specimens of the breed, still there was the true type amongst them, and some fair breeding stock might be selected therefrom. The majority were smooth-coated, though there were some roughcoated ones, and there is no doubt many of them, had they been well reared, would have turned out good specimens of the variety.

"Some of the most notable Swiss breeders, when speaking of their best specimens, appear proud of boasting of the humble origin of their favourites, and one of them remarked to me, 'Ah! I picked the sire of so-and-so out of a cart in - market.' Evidently the farmers and peasants are fond of their breed of dogs, but they make them earn their living in a hardish way, and it is a pity they do not attend to the rearing of them better; it would pay them well to do the latter.

"After a look through the market and other places of interest, we turned our steps to the Natural History Museum of Berne to see all that is left of the renowned Barry. According to the account in the museum Barry saved fifteen lives; other stories have given the number at from forty to seventy-five. I should take the Swiss Museum number as the correct one. Barry is a brindle and white patched smooth-coated dog, with a white muzzle, no blaze, rather long in head, narrow in muzzle at the end, 
but with good width below the eye; he is deficient in depth of skull, is small, I should say was not more than $26 \mathrm{in}$. or $27 \mathrm{in}$. high at the shoulder; he is down in the pasterns (this may be the fault of the man who 'set him up'), light in bone, and perfectly clear of anything approaching to a semblance of dew claws. I know it has been stated that the dew claws were probably taken off by the taxidermist, so I made a very careful examination of the hind legs and skin, and I now positively assert that Barry never had any dew claws.

"There are several heads of St. Bernard dogs to be found in the museum; also another stuffed specimen of the variety, a smooth-coated white dog, with a brindle patch on stern, and with an evenly marked head. This dog, though of fair size, is small in head. Some of the specimens of the heads are shapely and of good type.

"On the following day we started for Martigny. On the platform, at St. Maurice Station, I saw a very fair smooth dog, orange and white, patched, marked something like our English Keeper. This was far and away the best-headed St. Bernard I had seen in Switzerland up to now ; in other respects he is on the small side, and only fair in bone. Arrived at Martigny we made arrangements for the ascent of the Great St. Bernard on the following day. 
Martigny is the place which supplies the monks who take their turn of duty at the Hospice.

"On June 22nd we started for the Hospice of the Great St. Bernard, 7 a.m., in a carriage drawn by strong horses. Our first stopping place was Orsiers, where we rested for half-an-hour, and then went forward till we reached Liddes, where we had lunch, and changed our horses for mules, leaving the former to await our return the following day. Proceeding on our journey with the mules, and changing our Swiss driver for the Italian guides, the ascent became much steeper and the road rougher. In due course we arrived at our last stopping place, the Cantin di Proz, where the mules were taken out of the carriage and made ready for the completion of our journey in the saddle. Here I saw a very nice smooth-coated St. Bernard bitch and seven puppies, the latter about two months old, by Barry, a dog kept at the Hospice. One of the puppies was white, another had a half white face, another a white head, the remainder being fairly marked; the price asked for the puppies was from $£ 8$ to about $£$ i 2 each.

"We reached the Hospice about 6.30 p.m. quite tired out, and we were kindly received by one of the monks. We found it very cold here, and learned that the lake had been frozen over up to within a 
few days previously. The dogs, which were running in and out of the Hospice at will, had welcomed us on our arrival with a chorus of barks.

"After an excellent dinner of four courses, washed down with good wine, I turned out with an attendant, who acted as keeper, to have a good look at the dogs. These were seven in number; one a white with a few orange flecks on him; some of the others had all white or half white faces ; only two of them were really well-marked, as we understand the phrase, and with a single exception all were smooth in their coats. This exception was a good-coloured, small, rough-haired bitch. About one half of the inmates of the kennel had dew claws, either single or double, and the remainder were without them. The monks think nothing of the roughcoated dogs, and impress upon visitors that the smooth are the true race. All the smooths were of a good type, especially a big, good-coloured old dog named Barry (I think twenty-five per cent. of the dogs in Switzerland are named Barry). Most of these dogs at the Hospice have dewlap and wrinkle to a greater or less extent. With the exception of Barry, all were on the small side, and deficient in bone. When any strangers approach the Hospice the dogs bark, rush in-doors, and so give notice of the arrival. They then run out again and welcome 
the travellers by rushing up to them, wagging their tails, licking the hands of the visitors, and so escorting them to the Hospice. It will thus be seen that the dogs are very docile and quiet whilst loose and roaming about.

"At 8 p.m. the attendant called all the dogs together to be put up for the night. They stood in a row, and came up as he called them to be kennelled. Some of the kennels were loose boxes in the cow places on the ground-floor or cellar of the Hospice, the others in a similar place under the Refuge. The Refuge is the building near the Hospice, which was built for the inmates of the Hospice to resort to in the case of fire, and the Hospice has been twice burned down. When the dogs are kennelled they become quite fierce, and bark savagely if a stranger approaches their kennels.

"Next we were taken by one of the monks to see the library, museum, and chapel. In the latter is a painting of Bernard de Menthon and his dog, which we are asked to believe is the actual progenitor of the present race of St. Bernards. It is, however, but a common-looking creature, smooth coated, red in colour, about the size of a pointer, and as unlike the modern race as possible. At this I could not be surprised, as the painting had been executed some hundreds of years after the founder of the monastery 
had died, which he did about 108I, and so of course the artist had to draw on his imagination as to what the original St. Bernard dog was like. In those days, and for long after, the Hospice dogs were merely watch dogs, used to protect the monks from the incursions of robbers, from which they suffered to a great extent in the early times of their existence. I am sorry to say the monks keep no register containing pedigrees of their dogs. I saw a photograph of a very fine St. Bernard dog named Hospice Pluto. This dog is now dead, but his portrait proved him to have an enormous head, with very heavy lips and dewlap. The monks considered this dog by far the best they have had for some years.

"I was happily successful in bringing back the photograph of this dog, also of another, a dog that had been sold by the monks. for about $£$ i 30 in English money. The St. Bernards are still used in winter and bad weather in the duties which have made them historical. They are sent out to search the passes, on one side to the Cantin de Proz (Swiss side) and back to the Hospice, and, on the other side, from the Hospice to St. Remy (the Italian side) and back. After every fresh fall of snow the paths become obliterated, and many serious and fatal accidents are prevented by the intelligence and sense of the dogs, who by smell distinguish the 
proper roads. Here the monks told me that they found the long-coated dogs quite useless for work of this kind. Their jackets become matted with the snow, but worst of all it affects their feet, 'balling' and freezing between the toes to such an extent as to cause lameness so severe as to quite incapacitate them from walking. Indeed, the sores arising therefrom are sometimes so serious as to cause death.

"The following morning we were awakened at 4 a.m. by the ringing of the Hospice bell. Snow and rain mingled together came down in torrents, and the air was very cold; but we had breakfast at 6 o'clock, and then went to see the morgue. One of the monks took down a wooden shutter, and we looked through an open grated window, saw the bodies of travellers who had been found in the snow. We were told that the bodies were still quite fresh, though most of them had been there for years. About 8 o'clock the rain and snow abated, so we commenced our return journey to Martigny. I omitted to say that in my bedroom at the Hospice was a very good coloured drawing of a group of five St. Bernards. All these dogs were of the type of Hospice Pluto, before mentioned. At- Chamounix we saw no St. Bernards, but the proprietor of the Hotel Tête Noir said he had once kept some, but 
he had found them so expensive that he had given them up.

"At Brieg we went to see M. Seiler Muller, who is a large breeder of St. Bernards. He disposes of, they say, one hundred dogs each year. Here I was first introduced to three smooth puppies, three-and-ahalf months old, of very fair type; then came a dog and a bitch, fourteen months old, they were on the small side, the dog had just a fair head, the bitch was poor in that respect. Then came another bitch, with three nicely-marked young puppies; the dam was of rather nice type. The next to appear was a big-headed dog, middling in size and bone, he had an enormous skull, wide muzzle, which was deficient in depth, he was full in the cheeks, his ears were set a little too high; still this was a fair all-round dog. I saw several others, but there was nothing extraordinary neither here nor at Zermatt, where M. Muller keeps some of his dogs. Still, there was plenty of fair breeding stock.

"I was much disappointed in not finding any St. Bernard dogs at the Simplon Hospice, and continued our journey to Domo d'Ossola, Italy, and then forward to Lake Maggiore, where we stayed at the Grand Hotel Palanza, by the banks of the water. Here we saw a handsome, rough-coated St. Bernard. He is fourteen years old, terribly fat and wheezy; rather 
short on the leg, but quite a handsome old fellow. He belonged to the proprietor of the hotel, who was very proud of him.

"I did not come across any more dogs worth taking note of until reaching Lucerne, on the 2nd of July. From here I went to Arth, to see M. Carl Steiner, who is a noted breeder of my favourite dog, and the owner of the famous Pluto von Arth, whose stuffed remains form an object of interest in the museum at Zurich. I regret to say this dog was poisoned. M. Steiner was very pleased to see me, and showed me Bergman and Young Pluto. They are both sired by Pluto von Arth. Bergman was exhibited in England at the St. Bernard Club Show, held at Kingston in I893. I must say he looked a different creature here to what he did there when he obtained the reserve. He is a big dog, was in splendid condition, and good all round, if we except his head, which is plain. His brother, Young Pluto, was far and away the best smooth dog I saw in Switzerland. $\mathrm{He}$ is an orange and white dog, of the type of our champion Keeper, but he is not so good in muzzle; he is also rather straight in stifles. However, Young Pluto is an excellent dog, and one that any man might be proud to own. I next saw a magnificent bitch pup Gemmi d'Arth, by Bergman. This youngster was already a giantess, though only six 
months old; in colour, orange and white patched, with a lovely head and expression. Alas, I heard from M. Steiner, on my return, of her death, and I sympathise with him in the loss of such a grand specimen.

"A good many St. Bernards are to be seen in Lucerne and neighbourhood, some of them quite fair, but, as a rule, they are a poor, narrow-muzzled lot. After a short stay at Lucerne I went to Lauterbrunnen to see M. Gurtner (the brothers Gurtner are old breeders of St. Bernards), who is proprietor of the Hotel Steinbock there. I asked to see the St. Bernards, and arranged to stay the night with him, which I enjoyed very much, as M. Gurtner and I had a good long chat on the subject so congenial to both of us. Here I first saw a very fair bitch with six puppies. This bitch, I learned, had been given to M. Gurtner by Mr. W. O. Hughes-Hughes. I next saw a grand old rough bitch, own sister to champion Guide. She is very typical, like all the rest of her illustrious relatives. Then came a very good rough dog, Gyr. He shows age, but is a capital stamp, with an excellent head of the Bayard type. Another good sort of $\operatorname{dog}$ is Max, but his perfections were almost lost by the poor condition he was in. Pollux, the dog I particularly wished to see, was at Murren, but M. 
Gurtner kindly sent for him. This is a fine dog in many particulars, but I must confess I was rather disappointed, as I had heard so much about him. $\mathrm{He}$ is big, fairly marked on his head, white body, with patch of orange on stern and shoulders. His coat is too rough and wavy for one of the smooth variety, his head is massive, extravagant in lip and dewlap, the muzzle does not cut off square enough, and is narrow at the end, he is deficient in bone in his hind legs, where he is likewise too straight, and he is not the best of movers; nevertheless, he is of good type, and should be invaluable as a stud dog.

"From Lauterbrunnen I went to Biel to see the kennel of Major Fritz Blösch; here I was introduced to a nice orange and white bitch, excelling in head properties, and beautifully marked; also to a good rough-coated dog, orange and white patched body, with a well-marked head, and in splendid condition-his owner thinks a lot of him. I also saw two brindle and white six months' pups, well grown, but poor in head, but Major Fritz Blösch said he had some good ones in the country.

"From Biel I proceeded to Bale, and whilst there called on Dr. and Madam Siegmund, who are both well known as admirers of the St. Bernard. Of course I must go and see the dogs, and the first 
to come under my inspection was the rough-coated Czar (he is the sire of the smooth-coated bitch Arosa, imported lately by the Rev. A. Carter). This dog, a handsome orange and white, perfectly marked, stylish dog, is very active, beautiful in symmetry, but he is not quite so heavy in bone as English fanciers like, and his head, though fine in expression, is hardly massive enough in muzzle. Still, I considered him the best rough dog I had seen in Switzerland, and supported my opinion by purchasing him. He had taken first and special as the best rough-coated $\mathrm{dog}$ at Zurich Show this year (1893). I then saw a big dog puppy, ten months old, by Czar; he has an enormous head, the expression of which is spoiled by light eyes, and he is not quite sound on his hind legs. Two puppies, four months old, by Czar, are very promising. A good stamp of brood bitch finished this 'show.'

"In conclusion, I may say that I had a most interesting tour, thanks to my friends abroad, who were so good in showing me their dogs and imparting all the information I required. English breeders are under the impression that all the best St. Bernards are in England and in America. No doubt many of them are, but let me say there are excellent dogs still left in Switzerland, and the 
amount of material for breeding others is almost inexhaustible. In Switzerland they consider the smooths to be the representatives of the pure breed, and the roughs are thought little of except to mate with the smooths, which crossing gives the latter greater size and more stamina. The Swiss view as to the type is very similar to ours, but they lay great stress on the tail being turned up at the end so, $J$, and not straight as we like it: Some recommend that the bitches should not be bred from till they are at least three years old. I cannot say I agree with them on this point, but Major Fritz Blösch was about the only Swiss I met of my opinion, viz., that a bitch should be bred from at eighteen months old.

"The St. Bernard is still used in Switzerland for the purpose of finding the bodies of lost travellers or guides, and only a short time previous to my visit a guide was missing, but was ultimately found in a gorge buried in snow to the depth of several feet. The dog marked the spot, the rescue party set to work and, after digging for some hours, found the body in the place indicated by the sagacious animal. Respecting size, the Swiss say a dog from zoin. to 32 in. is big enough; they prefer a dog about 3 oin., and insist that we English go in for nothing but size. I told them they were mistaken in this 
idea, and, as examples to the contrary, mentioned the names of our champion dog Keeper and the bitch Gondola."

The following is the English Club's description of the St. Bernard:

"Head.-Large and massive, circumference of skull being more than double the length of the head from nose to occiput. From stop to tip of nose, moderately short; full below eye, and square at muzzle; great depth from eye to lower jaw. Lips, deep throughout, but not too pendulous. From nose to stop straight. Stop, abrupt and well defined. Skull, broad, rounded at the top, but not domed, with somewhat prominent brow.

"Ears.-Of medium size, lying close to cheek, but strong at the base, and not heavily feathered.

"Eyes.-Rather small and deep set, dark in colour, and not too close together, the lower eyelid drooping, so as to show a fair amount of haw.

"Nose.-Large and black, with well-developed nostrils.

"Teeth.-Level.

"Expression. - Should betoken benevolence, dignity, and intelligence.

"Neck.-Lengthy, muscular, and slightly arched, with dewlap developed. 
"Shoulders.-Broad and sloping, well up at the withers.

"Chest.-Wide and deep.

"Body.-Back, level as far as the haunches, slightly arched over the loins; ribs well rounded, and carried well back. Loin, wide and very muscular.

" Tail.-Set on rather high, long, and, in the longcoated variety, bushy; carried low when in repose, and, when excited or in motion, slightly above the line of the back.

"Legs and Feet.-Fore-legs, perfectly straight, strong in bone, and of good length. Hind legs, heavy in bone, well bent at the hocks, and thighs very muscular. Feet, large, compact, with wellarched toes.

"Size.-A dog should be at least zoin. in height at the shoulder, and a bitch 27 in. (the taller the better, provided the symmetry is maintained); thoroughly well proportioned, and of great substance. The general outline should suggest great power and capability of endurance.

"Coat.-In the long-coated variety, should be dense and flat; rather fuller round the neck; thighs feathered, but not too heavily. In the short-coated variety, should be dense, hard, flat, and short, slightly feathered on thighs and tail.

"Colour and Markings.-Red, orange, various 
shades of brindle (the richer the colour the better), or white with patches on body of either of the above-named colours. The markings should be as follows: White muzzle, white blaze up face, white collar round neck, white chest, fore-legs, feet, and end of tail; black shadings on face and ears. If the blaze be wide and run through to the collar, a spot of the body-colour on the top of the head is desirable."

\section{OBJECTIONABLE POINTS.}

Ill-temper.

Split nose.

Unlevel mouth and cankered teeth.

Snipy muzzle.

Light or staring eyes.

Cheek bumps.

Wedge head.

Flat skull.

Wall eyes.

Domed skull.

Badly set or heavily feathered ears.

Too much peak.
Short neck.

Curly coat.

Curled tail.

Flat sides.

Hollow back.

Roach back.

Ring tail.

Open feet or hare feet.

Cow hocks.

Straight hocks.

Self-coloured (i.e., a selfcoloured dog is one that has no black shadings or white markings.

\section{DISQUALIFYING POINTS.}

Dudley, liver, flesh-coloured nose.

Fawn, if whole-coloured, or with black shadings only.
Black, black and tan, black and white, black tan and white, and all white, 
The numerical points are as follows, but they are not drawn up by the Club :

\begin{tabular}{|c|c|c|}
\hline & Value. & \\
\hline Head, ears, eyes........... & 25 & Stern $\ldots \ldots \ldots \ldots \ldots$ \\
\hline Expression and character. & 15 & Legs and feet........... \\
\hline Neck, shoulders, and chest & 10 & Coat $\ldots \ldots \ldots \ldots . . . . . . . . .$. \\
\hline Body $\quad . . . . . . . . . . . . . . . . . . .$. & 15 & Colour and markings... \\
\hline
\end{tabular}

\section{Grand Total 100.}

The weight of a dog may be from I 7olb. to $200 \mathrm{lb}$. or more; of a bitch from I 50 lb. to I $80 \mathrm{lb}$.

That there is no fear of the St. Bernard dog becoming extinct, as at one time appeared to be not unlikely, may be inferred from the fact that $\mathrm{Mr}$. Hughes-Hughes has just published a volume containing the pedigrees of nearly six thousand St. Bernards. The names of many of them are not to be found in the Kennel Club's publications, Mr. Hughes-Hughes obtaining particulars of such during his visits to Switzerland. A troublesome work carefully compiled. 



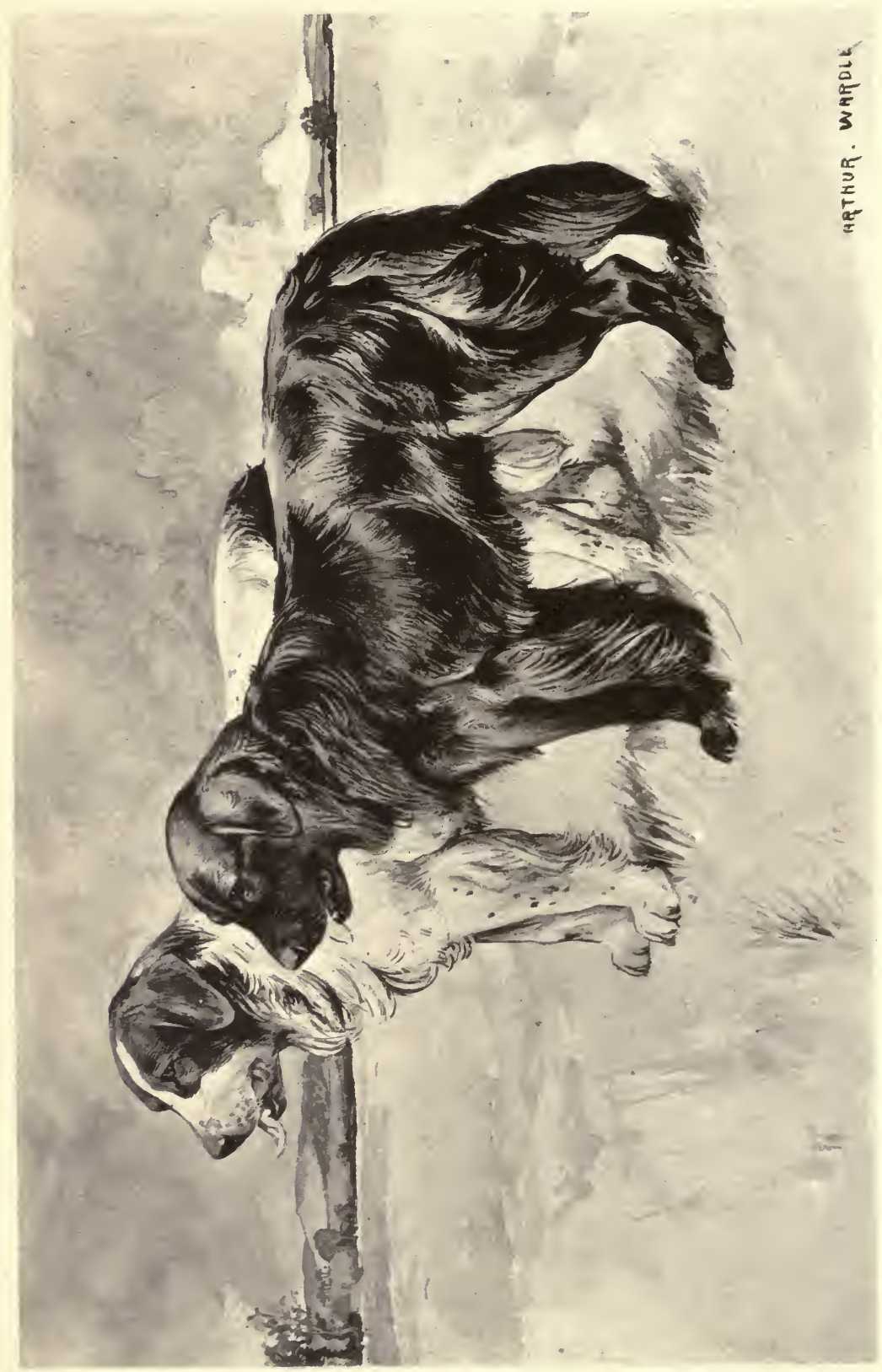




\section{CHAPTER III. \\ THE NEWFOUNDLAND.}

UNTIL the St. Bernard became popular in this country the black and white Newfoundland dog appeared to hold the admiration of the public. He had been a hero in his own line, and " the travellers' tales" had informed us that this large dog occupied itself in its native country in saving the lives of drowning sailors and swimming with a rope in its mouth to some stranded vessel, and thereby enabling the shipwrecked mariners to obtain communication with the mainland and so escape a watery grave. Then, when brought here, the Newfoundland dog still maintained its liking for the water. On more than one occasion it had been known to save a drowning child, and Landseer further immortalized it by painting his great work "A Distinguished Member of the Royal Humane Society," a black and white Newfoundland dog, abounding in dignity and repose, which perhaps has been engraved and republished oftener than any other work of the great 
animal painter. Fifty years ago a large proportion of the anecdotes of dogs related to the sagacity of the Newfoundland. Whether he really deserved all the good things that were said of him is a matter of opinion, or perhaps he has degenerated in intelligence during the past half century, for he is now only as other dogs and no more.

How he came to be so intimately connected with the island in North America from which he takes his name is not quite easy to make out. Possibly he might have been introduced to that country from England, still the dog common to the island a couple of generations ago was very far removed from the handsome creature we see gracing our show benches at the present time.

One would not be surprised to find the St. Bernard and the Newfoundland did originally spring pretty much from a similar cross. Occasionally we still see one of the former variety by his colour and general appearance nearly approaching the latter in appearance, and vice versâ, especially when, as sometimes happens, the Newfoundland has brindled marks about his head. We are told that an actual use for this variety of dog was found by the poorer inhabitants of Newfoundland, who in lieu of horses harnessed him to their carts and in other ways made him a beast of burden, when they were not engaged 
in fishing operations. Moreover, these poor dogs were badly treated, fed on the offal of the cod fish when it was procurable, and when such was not to be had the poor canine had to make shift for himself, and either starve or take toll from the flocks of the wealthier inhabitants.

Notwithstanding such ill-treatment, the dog remained faithful and constant to his owner, and bore the reputation as a protector of property not to be excelled. For these excellences then, and not for his actual beauty, was he originally produced, and no doubt when some seafaring man noticed one of these animals less gaunt and better furnished than usual, he for a few shillings would become its possessor, and bring the "foreign" dog home as a present from America to his friends. When properly cared for and attended to he would no doubt improve in appearance, was a favourite with his owners, and became as it were re-acclimatised in that country from which I do not doubt his original parents came. The Newfoundland is so unlike any of the native bred canida of the northern territories of America in every respect, not excepting in disposition, that there can be little doubt he was in the first instance produced by cross-breeding with European dogs, and most probably with those from Great Britain, whose shipping connection with New- 
foundland has always been greater than that of any other country.

Little was heard about the Newfoundland dog until towards the beginning of the present century. Bingley, in his "Natural History," date 1809 , does not allude to him, but a little earlier the "Sportsman's Cabinet " mentions him as being " universally known in every part of the kingdom." Reinagle gives an illustration of the dog, a black and white, very much of the same type as we have now, and the writer of the article in the work named eulogising him in grandiloquent terms, makes him indeed a canine prodigy. But, as we have said, our modern dog and that originally brought from the island are totally distinct, and even so far back as when Richardson wrote, about 1845 , the difference was acknowledged, and the strain known in this country was said to be "less sagacious, less active, and more apt to display irregularity of temper than the original breed," which was much the smaller animal of the two.

Here we have more to do with the Newfoundland in 1893 than with what he was said to be very much earlier in the present century. Now we have two distinct Newfoundlands: the one quite black, where even a white chest and white toes are supposed to be a disfigurement to a certain extent; the other black and white, called "Landseers," after the artist, 
whose famous picture has already been alluded to. The so-called St. John's, or lesser Newfoundland, of which much has been written, appears to have died out altogether. No one breeds him now, and if he survives at all it is in the smooth or wavy-coated retrievers that have made such progression of late.

The author of "Dogs of the British Isles" had a typical specimen of the Newfoundland-given him on the death of the "Old Bushman" (whose works on travel and sport are most interesting) - a dog the latter had imported as the best of the race he could find; handsome, but not quite so big as many of the English specimens, he standing 28in. high at the shoulders. His colour was a rusty black, which is seldom seen now, but no doubt quite correct, and he had double dew claws. My old and esteemed friend, the late Mr. William Lort, always impressed upon me that this "rustiness" in the colour was correct, and further remarked that all the best dogs he ever saw abroad possessed it to a larger or smaller extent.

A contributor, writing to the Field in I 869, and he wrote with authority, said with regard to this tinge: "The black dogs, especially when young, often appear to have a brown tinge in their coats. It is to be seen more or less in most dogs. Combing will often remove it if the dog has not been well kept, 
but I do not think much combing is advisable. Nor is the slight brown tinge (not visible in all lights) ugly, nor inconsistent with the purity of breed, though it would be better absent." A writer much earlier than this, namely, in 1819 , says that twenty or thirty years ago the Newfoundlands were "large, roughcoated, curly-haired, liver and white dogs." Occasionally we now see a Newfoundland dog entirely liver or brown in colour, and doubtless this hue is inherited much in the same way as the brown tinge, and therefore I quite agree with the description of the specialist club, which does not penalise that tint. The brown or brown and white dogs it does not acknowledge, and naturally gives preference to those specimens entirely black.

In the early days of the canine exhibitions, prizes were often given to black and white dogs when shown in the same division as the blacks, but the latter, when equal in excellence to their more variegated cousins, in nine cases out of ten beat them, so breeders gave their attention mostly to the whole-coloured variety, which causes it to be the popular one of the present day. The first dog show held at Birmingham, in I859, was entirely confined to sporting dogs, but the succeeding one in 1860 included a class for Newfoundlands, and this induced an entry of only half a dozen, a bitch of Lieut.- 


\section{The Newfoundland.}

Colonel Inge's winning the first prize. Of this bitch it was said at the time that "she was one of the handsomest ever seen, and had been bred at St. John's, from the best stock in the colony." At the Agricultural Hall, in 1862 , classes for both dogs and bitches were provided. There was a capital entry of forty-one, and Mr. A. Minton's Nigger won in dogs, and a Mr. Davies both prizes in bitches. Birmingham had seventeen entries in the same year, and at a large exhibition, also in I862, which took place in Holborn, nineteen entries were obtained, a dog named Azoff first. Two years later, H.R.H. the Prince of Wales, at the London show, won first prize with a fine dog called Cabot, and most of these early winners were either black or with a little white on their chests, or on one or more of their feet. H.R.H.'s Cabot must not be confounded with Mr. T. Burgess' dog of the same name, which did a considerable amount of winning a few years later. However, few of the above were of any particular excellence; but in 1867 , at Curzon Hall, we were introduced to the Rev. S. Atkinson's Cato, who was by Heenan I. out of Nellie. Both the sire and dam of Cato were said to be descended from imported parents.

Cato was an exceptionally fine black dog, and for a series of years remained the monarch of the benches. 
In 1869 he won in a class of sixteen dogs at the show held in Laycock's Dairy Yard, where Mr. E. Nichols was an exhibitor, and old show-goers will recollect that the cover of the catalogue issued on this occasion was adorned with an engraving of Landseer's "Distinguished Member."

Then in 1870 Cato gained additional notoriety. It was in that year his owner was staying at the charming little watering place, Newbiggin-by-theSea, on the Yorkshire coast. Cato was there, too, to blow the dust of town from him, for just before he had been in London, and as usual, winning the chief prize at the dog show there. As Mrs. Atkinson was throwing her husband's walking-stick into the water for her dog to retrieve, two ladies bathing in the sea appeared in danger of drowning, and cried loudly for help. Though Mr. Atkinson could not swim, he made his way to the ladies, who, now and then washed off their feet by the heavy surge, had lost their presence of mind. One lady was safely got into a boat that had been brought to the rescue; the other, with $\mathrm{Mr}$. Atkinson, was in danger of being drowned. Then Cato came to the rescue, and, swimming to his owner, allowed him to put his arm over his shoulder, and so took his exhausted master and his fair charge to the shore, where the dog received the plaudits of the terrified spectators. 
No doubt, taking one exhibition with another, the classes provided for Newfoundlands were almost as well filled about twenty years ago as they have been later. For instance, there were in the dog class but nine entries at Curzon Hall in I89I, five in bitches, and nine in a division for novices; whilst five of the latter were competing earlier on, thus there were but eighteen dogs benched at this great show in three classes. This can hardly be taken as a fair average, for most modern shows would provide additional classes for the black and white variety, and the Kennel Club Shows usually have from twenty to thirty competitors. At Preston (Lancashire) Show, which took place in the spring of 1892 , special arrangements had been made to make Newfoundlands one of the features in the Hall. Here the judge, Mr. Mansfield, an ardent admirer of the breed, and one of the promoters of the gathering, by his endeavours got together by far the best collection of Newfoundlands that had been seen at any show for years. Altogether $128 \mathrm{dogs}$ and bitches competed, they being divided into ten classes. No doubt this will remain a record for some time to come.

However, before entering more fully into the Newfoundland in 1893 , mention must be made of one or two giants of the race that won most of the 
prizes say a dozen years or more ago. Winning about I 880 and later was Mr. Howard Mapplebeck's Leo, an uncommonly fine dog, and, like most others, said to be descended from imported parents on both sides. He was black in colour, and at times showed a little of the rusty tinge. He stood about 30 inches in height at the shoulders, and weighed i $36 \mathrm{lb}$. He was a very big dog.

Mr. T. W. Wildman, of Bingley, about this period gave considerable attention to the exhibition of Newfoundlands, and possessed admirable specimens in such animals as Lion, Mayor of Bingley, and Black Prince, which were, however, rather smaller dogs than either Cato or Leo alluded to earlier on. Mr. R. W. Moll was exhibiting some excellent dogs at this time, and so were Mr. W. Coates, Mr. H. R. Farquharson, and Mr. E. Nichols.

The Newfoundland has never taken particularly high rank as a show dog, nor does the establishment of a club to look after his welfare appear to have very much increased his popularity, though at the present time there are more good Newfoundlands both black and other than black in the country than has been the case previously. But sometimes he is judged in a rather in and out fashion, and on more than one occasion recently have I seen a second rate dog placed over one that could in every 
way be deemed in the first rank, and for no other reason than the mere caprice or whim of the judge.

A few years ago there was considerable agitation as to the swimming powers of Newfoundlands, and on two or three occasions water competitions were arranged in connection with dog shows. Such, however, proved neither popular nor interesting, and in one noteworthy case a very much-lauded dog refused to enter the water at all. The last competition of the kind was at Aston, near Birmingham, in 1882 , where the best water dog was undoubtedly the late Mr. Bagnall's Landseer, Prince Charlie, which won a first prize, a Bedlington terrier being his most formidable opponent.

It may be worth mentioning that the Newfoundland $\operatorname{dog}$ as he is now found in the island which gave him his name, is a sad mongrel creature, if he exists at all in any amount of purity. It is likewise noteworthy that in the United States of America no Newfoundlands are kept anything at all equal to the best specimens of the variety as we have produced them in the British Isles.

Although I have owned a Newfoundland or two, I never had one. sufficiently long or made his acquaintance to such an extent as to be able to speak with great authority on the nature and disposition of the animal. My lack of opportunity in this 
respect can, however, be easily remedied, and Mr. T. E. Mansfield, a gentleman whose favourite the Newfoundland has been for many years, kindly contributes the following practical, and therefore valuable, notes. He says :

"The Newfoundland is essentially a companionable dog, his whole nature is wrapped up in human beings, anxious to serve them at every turn; his disposition is kindness in itself, and he adapts himself to every emergency, and can be taught almost anything, even to make as good a rat catcher as a terrier. Some Newfoundlands are slow to make friends, but when once that relationship is established they never forget you, and are steadfast companions through life, and to their owner what the poor man's mongrel dog was to him,

Made him more content with fate.

"Of course there are, as in all things, exceptions but taking him as a whole no more suitable dog as a companion can be found than a good Newfoundland.

"During the last ten years the Newfoundland has grown in popularity by leaps and bounds. I find at the Kennel Club Show in July, I885, there were eight classes with thirty-seven entries. Seven months later, at the same club show, there were 
again eight classes with seventy-one entries. At the Jubilee Show in June, I887, there were nine classes with sixty-five entries to be found. It is not only at the Kennel Club Shows that the entries have so largely increased, but at all the provincial shows. Prior to and some little time after the year 1884 , it was rarely we saw more than one class for Newfoundlands, with from three to half a dozen entries. Then Liverpool came off with sixty-five entries, and so they go on increasing until Preston Show of 1892 reached the enormous entry of 128 .

"Not only in numbers, but in the type and quality of the dogs has this improvement gone on, until there is at the present day-in the blacks at all events - an entire absence of that large coarsewith rough soft coat, big ears, long face, flat bowed legs without muscle, and with no general appearance to recommend him-type of dog, so frequently seen years ago. It is to be hoped breeders of Newfoundlands will not be led away with the idea prevailing in some quarters that size is the principal thing at which to aim. Herein lies a very great danger. Whilst, however, admitting that size is very desirable, it must not be gained at the expense of type and general appearance, for a Newfoundlander must not be an awkward, slouching animal, but smart, active, 
and full of life and go-looking at all times ready to perform his duty - to enter a rough sea.

"To give an accurate description of a black Newfoundland is an extremely difficult task, for the simple reason that a really typical dog is in appearance almost indescribable; he must be seen to be appreciated. I will, however, attempt what I consider a fairly intelligible one. To begin with, he must have $\mathrm{a}$ good general appearance - symmetrical throughout-head should be well developed, with a clean-cut muzzle, not too long, large skull, with small, leaf-like ears set well back from the eye low down on the skull, and fall close to the head, so that when you look him in the face they are scarcely perceptible, being hidden at the back of the jawbone; the eyes should be dark-not black-and fairly wide apart. Much difficulty is being experienced in getting the dark eye, which adds so much to the appearance of the head, many of the best dogs having light eyes, and the question is, where does this defect come from? You may mate a darkeyed dog and bitch, still light eyes will be found in their progeny. It has occurred to me that the light eye must to some extent be natural to a black animal, for a black cat has always a light eye, and a black horse has generally a light blue one, and so I might go on down to pigeons. I must admit I 
would much rather see a kind light eye than a black sour one, which always appears most treacherous.

"The fore legs should be straight, well lined with muscle, to give them a round, powerful appearance, ending with good; large, well closed feet, standing on them like a terrier. The chest above must be wide, and come well down, giving the dog a bold, broad front; the body should sway well between the fore and hindquarters, and not tucked up at the loins; powerful hindquarters, with no horrible cowhocks, and ending with a tail the length of which should not reach below the hocks, be without a kink, curl, or curve, and carried low down. There is nothing to my mind more unsightly in a Newfoundland than a tail curled on the back or with a kink in it; personally I like to see the tail carried more after the style of a setter, and do not quite agree with the Club's authorised carriage of tail. Now as to coat. To obtain a correct coat is another difficulty, and to describe a proper one is about as difficult; the purpose for which it is required makes it so. It must, however, be straight, without wave or curl, long coarse hair, not wool, with a good warm under coat, which water will not penetrate; the arrangement being, that, when the dog comes out of water and shakes himself, which 
he invariably does, the water is thrown off, and he is dry in a very short time.

"Looking at a good, well-built dog should be like looking broadside on at a first-class cob; he must be built on similar lines. The average height of a dog is $28 \mathrm{in}$., and bitches $25 \mathrm{in}$. to $27 \mathrm{in}$., at the shoulder. For a more detailed description of the points of a Newfoundland I must refer readers of these notes to the Newfoundland Club's description, which is printed below.

"It may not be out of place here to give a short description of some of the best Newfoundlands' kennels of the present day, but I cannot in justice do so without first travelling back a few years to bring in poor old Champion Nelson I., a dog that may well be said to have been the father of Newfoundlands in this country. In doing so I must not forget his breeder, Mrs. Cunliffe Lee, a lady who has probably had little credit given her for the part she has played in producing several really first-class dogs. Nelson I. was not large in size, but quite large enough, and answered well the above description of a Newfoundland. From this grand old dog we may trace the present race of high-class Newfoundlands, many of which I shall hereafter mention. From Mrs. Lee he went to the kennels of $\mathrm{Mr}$. E. Nichols, and there he was mated with a bitch 
with pedigree unknown, named Jennie. From this alliance was produced, in the year I88I, a litter of six, all of which have left triumphant records in the exhibition world and Stud Book, their respective names being Courtier, Bruce II., Lady Mayoress, Lady-in-Waiting, Sybil, and Mistress of the Robes.

"From them may be traced the foundations of half a dozen kennels, which I will shortly describe, and commence with that of Mr. E. Nichols, of St. Mary Abbott's Terrace, Kensington, who for years, it may be said, quite took the lead as a breeder of Newfoundlands. Nelson I. and Lady Mayoress were almost invincible in the show ring; indeed, Lady Mayoress in her time beat every dog and bitch living except her sire, Sybil also doing excellent service. After breeding numberless high-class good dogs, Mr. Nichols secured Lord Nelson, a son of Nelson I., from Mrs. Lee, his breeder, and this young dog, at eighteen months old, astonished the Newfoundland world, as he combined great size with all the points of a good dog. Brought out at the Crystal Palace, he "cleared the board," won great honours for several years, but eventually he grew rather coarse, and had to make way for others.

"Following Mr. Nichols' comes the kennel of Mr. H. R. Farquharson, M.P., of Eastbury Park, Bland- 
ford, and president of the Newfoundland Club since its establishment in I886. In their infancy Mr. Farquharson purchased, from Mr. Nichols, Courtier, Lady-in-Waiting, and Mistress of the Robes, all of which did credit to this well-known kennel, for, besides winning prizes, Lady-in-Waiting produced such dogs as Hanlon, Alderman, and Bismarck. Hanlon, who secured his championship by successive wins at Kennel Club Shows, is a regular Newfoundlander, his ears are slightly too large, and that is all the fault that can be found with him. This kennel also contained the well-known dogs Joe Sadler (the sire of Hanlon) and Gunville.

"Mr. C. W. Cunningham, of Marloes-road, W., the secretary of the Newfoundland Club, has been mixed up with Newfoundlands all his life. He owns Black Prince II. and some very good bitches, and is one of the most earnest members of his club in looking after the interests of his favourite dog. Another modern enthusiast is Mr. C. C. Ralli, of Brunswick Buildings, Liverpool. Mrs. Matthews, Barrow-in-Furness ; Mr. Crossfield, Captain Jolly, Mr. James Green, Mr. W. C. King. Dr. Jackson, Mr. J. Caroline, Mr. W. Paterson, Glasgow; Mr. H. Champness, Westminster; and Mr. J. W. Bennett, own good specimens at the present time, and in Master Jumbo Mr. C. Haldenby, of Hull, shows one 
of the most typical black Newfoundlands of the day, though he does carry his tail badly at times. Miss Rich's Black Guard II., who won the championship at the last Kennel Club Show, is also a particularly fine specimen of the breed.

"I must say something of my own kennels, in which we have had between thirty and forty Newfoundlands at one time. After purchasing Leo V. and Champion Zoe, we found we were on the wrong road, but we had, under the guidance of Mr. Nichols and Mr. Farquharson, obtained Courtier, Lady Mayoress, and Gunville, also The Black Prince, Sybil, and Mistress of the Robes, with which we were very successful as exhibitors. Later we bred such notable dogs as Alliance, Coastguard, Jack Tar (now the property of Mr. S. Cameron, of Melbourne), Armada, Sea Nymph, and many others. We also brought out a young dog, Pirate King (bred by Mrs. Lee, and a son of Courtier), which soon became a champion, and passed into the hands of Mr. W. Paterson, of Glasgow. So recently as the autumn of 1893 Mrs. Mansfield showed an excellent young dog at the Kennel Club Show called Piermaster, by Hematite from Lady Mayoress II."

Perhaps the variety of Newfoundland dog best known to the general public is that black and white 
in colour, once distinguished as the Landseer Newfoundland, out of honour to the great animal painter of that name, one of whose happiest works was a representative black and white dog, "A Distinguished Member of the Royal Humane Society." However, the Newfoundland Club, which, I suppose, has the management of such things, in order that good specimens that may be brown in colour or black with a little white on their chests or feet are not debarred from competition, classify the "Landseers" under the heading of "any other than black." The "Landseer" proper would be, when properly marked, a black headed dog with a broad strip of white down the face, some white on the cheeks, and a body more or less patched with black. Such are handsome dogs, and a few years ago, before shows were so firmly established as they are now, the black and white Newfoundlands were more commonly seen than the ordinary black variety. Mr. Mansfield writes of them as follows:

"They have not made such progress as the blacks for the simple reason that breeders of this variety will not go to the black dogs to improve the coat and type of their black and whites. They appear to completely ignore the fact that the qualification is not simply a black and white dog with handsome white markings. The marking is a very tenth rate 
consideration. First and foremost it is necessary in the class for 'other than black Newfoundlands' that to be successful the competitor should be, though black and white, exactly of the shape, make, and character of a good black specimen. Then and then only must come the question of colour and markings. Of course, other things being equal, a well marked dog should have the preference. The majority of the dogs in this division are bad in coat, which often resembles the wool on the back of a Shropshire sheep; they generally fall off in their hindquarters, being tucked up in the loin and leggy, and lack quality and type. By perseverance these failings could be remedied by judiciously crossing with black dogs of the right type. Mr. Farquharson's Rosebud was a beautiful specimen of a white and black Newfoundland ; in fact, on her first appearance she beat all the black bitches at a Kennel Club Show. She was almost white, and was by Trojan, a black dog with white chest and feet, out of Leda, a bitch similarly marked. So much for the other than black variety." Mr. Mansfield proceeds :

"Returning to the Newfoundland generally, sometimes a brown or bronze pup will be produced, but this is of rare occurrence. I have never had one from a pure Nelson I. and Courtier strain, but have on several occasions had such from the Leo blood. 
"With regard to rearing puppies, the most ticklish time for them is during whelping, and up to ten days old. A practice I adopt is to have a hamper ready, with clean, soft straw in the bottom, and as each puppy is whelped it is placed in this hamper in front of a fire, always leaving one with the bitch, but before removing into the hamper it is always put to suck. By this means the whole lot are kept dry and warm, and the bitch is not hampered with a heap of whining puppies round her. For seven to ten days they are thus kept in hampers, being put to the bitch every hour, night and day. It is rarely by doing this (which of course means trouble) that a puppy is lost, and they thrive well. If left to take their chance some die from cold, others are laid on and killed. For many years I have carried out the above plan with great success. At the end of a month they should be fed with milk, with sugar and water added. At six weeks 1 feed them on raw paunches cut up small, and they rarely get anything else for the remainder of their existence in my kennels. I believe in raw meat for dogs, it is their natural food, and it will never harm them or make them savage."

The Newfoundland Club, established in 1886 , is a representative body, of which Mr. H. R. Farquharson, M.P., is president, and Mr. E. 
Nichols vice-president. The following is the description this club has issued of the Newfoundland dog:

"Symmetry and General Appearance.-The dog should impress the eye with strength and great activity. He should move freely on his legs with the body swung loosely between them, so that a slight roll in gait should not be objectionable, but at the same time a weak or hollow back, slackness of the loins, or cowhocks, should be a decided fault.

"Head.-Should be broad and massive, flat on the skull, the occipital bone well developed; there should be no decided stop, and the muzzle should be short, clean cut, and rather square in shape, and covered with short fine hair.

"Coat.-Should be flat and dense, of a coarsish texture and oily nature, and capable of resisting the water. If brushed the wrong way it should fall back into its place naturally.

"Body.-Should be well ribbed up with a broad back. A neck strong, well set on to the shoulders and back, and strong, muscular loins.

"Fore Legs. - Should be perfectly straight, well covered with muscle, elbows in but well let down, and feathered all down.

"Hind Quarters and Legs.-Should be very 
strong; the legs should have great freedom of action, and a little feather. Slackness of loins and cowhock are a great defect. Dew claws are objectionable and should be removed.

"Chest.-Should be deep and fairly broad and well covered with hair, but not to such an extent as to form a frill.

"Bone.-Massive throughout, but not to give a heavy, inactive appearance.

"Feet. - Should be large and well-shaped. Splayed or turned-out feet are objectionable.

"Tail.-Should be of moderate length, reaching down a little below the hocks; it should be of fair thickness, and well covered with long hair, but not to form a flag. When the dog is standing still and not excited, it should hang downwards with a slight curve at the end; but when the dog is in motion it should be carried a trifle up, and when he is excited straight out with a slight curve at end. Tails with a kink in them, or curled over the back, are very objectionable.

"Ears.-Should be small, set well back, square with the skull, lie close to the head, and covered with short hair and no fringe.

"Eyes.-Should be small, of a dark brown colour, rather deeply set but not showing any haw, and they should be rather wide apart. 
"Colour.-Jet black. A slight tinge of bronze, or a splash of white on chest and toes is not objectionable.

"Height and Weight.-Size and weight are very desirable so long as symmetry is maintained. A fair average height at the shoulder is 27 inches for a $\mathrm{dog}$, and 25 inches for a bitch, and a fair average weight is Ioolb. and $85 \mathrm{lb}$. respectively.

\section{"OTHER THAN Black.}

"Should in all respects follow the black except in colour, which may be almost any so long as it disqualifies for the black class, but the colours most to be encouraged are bronze, and black and white, beauty in markings to be taken greatly into consideration.

\section{“Addenda to 'Other than Black.'}

"Dogs that have been entered in black classes at shows, held under Kennel Club Rules, where classes are provided for dogs 'other than black' shall not be qualified to compete in other than black classes in future.

"Black dogs that have only white toes and white breasts, and white tip to tail, are to be exhibited in the classes provided for 'black.'” 
The club has not issued any numerical scale of points, but these I should allow as follows :-

\begin{tabular}{|c|c|c|c|}
\hline Head and expression & $\begin{array}{c}\text { Value. } \\
15\end{array}$ & Stern & $\begin{array}{c}\text { Value. } \\
\text { to }\end{array}$ \\
\hline Neck and chest ............ & 10 & Size $\ldots \ldots \ldots \ldots \ldots \ldots \ldots$ & 10 \\
\hline Back and loins ........... & IO & Symmetry and general & \\
\hline Legs and feet.............. & 15 & appearance ............ & 10 \\
\hline Coat and colour............. & 20 & & \\
\hline & 一 & & - \\
\hline
\end{tabular}

\section{Grand Total 100.}

Weight of dog from 85 lb. to Ioolb.; of a bitch, $75 \mathrm{lb}$. to $85 \mathrm{lb}$. 



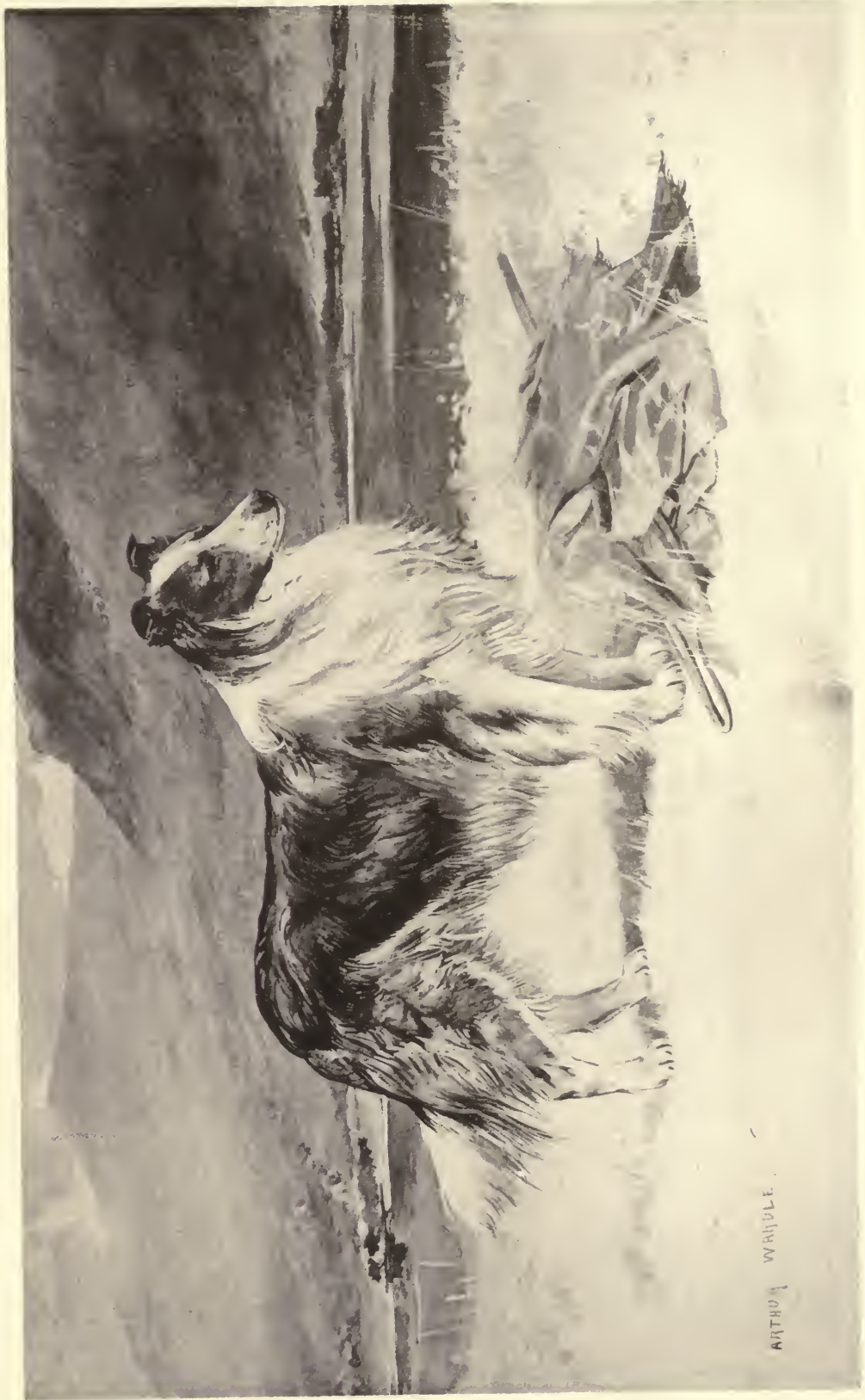




\section{CHAPTER IV. \\ THE COLLIE OR SHEEP DOG.}

Although the "Scotch collie dog," as he is so often called, has for many generations been one of the favourite varieties of the canine race, his fondest admirers of fifty years ago could scarcely have expected him to have achieved the popularity which he possesses at the present time, and has held for some fifteen years or more. He may share with the sprightly fox terrier the distinction of being the favourite dog of the people of the latter part of the nineteenth century. The St. Bernard has his admirers, so has the foxhound, but as neither is so suitable as a companion-the one on account of the size, the other for a variety of reasons, the collie and the fox terrier are likely to retain their good reputation for many years to come.

The sheep dog is usually called a "collie"; in reality a "collie" is an obsolete name for "such sheep as have black faces and legs," says the Agricultural Dictionary, published in I743, where 
it is spelled "colley," as it is sometimes even nowadays. As a fact, there is no rule for spelling the word, and as "colley" in many parts of the country is the name of a small fresh-water fish, the loach, the spelling "collie" for a sheep dog I take to be best.

Shakespeare uses the word in one or two instances with the meaning of dark or black, thus-

Brief as the lightning in the collied night.

The word collie is derived from the Anglo-Saxon "col," black, so the black-faced sheep of the North came to be called "colleys," and the dog that drove or preceded them came to be a colley dog. In due course the word dog was dropped, so, by easy transformation, "colley"-grown out of use as applied to the sheep-was adopted as a euphonious word for a variety of the dog, and so remains to this day. Bewick, the great wood engraver, calls this dog the "coaly."

But before Bewick gave us his charming illustrations the sheep dog or "shepherd's hound," Canis pastoralis, was held in esteem, and in the sixteenth century duly described by Dr. Caius. He says :

Our shepherd's dog is not huge, and vast, and big, but of an indifferent stature and growth, because it has not to deal with the bloodthirsty wolf, since there be none in England. . . . This dog, either at the hearing of his master's voice, or at the wagging of his fist, or at his shrill and hoarse whistling and 
hissing, bringeth the wandering wethers and stray sheep into the self-same place where the master's will and work is to have them, whereby the shepherd reapeth the benefit, namely, that with little labour and no toil of moving his feet, he may rule and guide his flock according to his own desire, either to have them go forward or stand still, or to draw backward, or to turn this way, or take that way. For it is not in England as it is in France, as it is in Flanders, as it is in Syria, as it is in Tartary, where the sheep follow the shepherd, for here in our country the shepherd followeth the sheep, and sometimes the straying sheep, when no dog runs before them, nor goeth about and beside them, gather themselves into a flock, when they hear the shepherd whistle, for fear of the dog (as I imagine), remembering that (if unreasoning creatures may be reported to have memory) the dog commonly runneth out at his master's warrant, which is his whistle. This have we oftentimes marked when we have taken our journey from town to town; when we have heard a shepherd whistle, we have reined in our horse and stood still a space to see the proof and trial of this matter. Furthermore, with the dog doth the shepherd take the sheep to slaughter, and to be healed if they be sick, and no hurt or harm is done by the dogs to the simple creature.

The above is one of the oldest records we have of the working of sheep dogs, and it is interesting because it almost exactly corresponds with their duty at the present day.

It must not be forgotten that the sheep dogs of other countries, and probably in England, when wolves and other wild beasts abounded, are and were much more ferocious and powerful creatures than our collies. The so-called Pyrenean guard dog we often see on our show benches, is a dog some 
one hundred and twenty pounds weight and more, roughish in coat, and with a docility of expression quite in keeping with the pastoral duties he has to perform, and with strength sufficient to grapple with a wolf successfully.

However, the largest type of foreign sheep dog I have met was one said to be from Thibet, and which was purchased from a traveller by a firm of live-stock importers in London, Messrs. Willson and Co., of Goodge-street, London, W. This was, perhaps, as tall a dog as I ever saw, measuring at the shoulders $33 \frac{3}{4}$ inches, and built proportionately. It was pale fawn in colour, with a close thick coat, inclined to be shaggy rather than smooth; his face was as kindly in expression as anyone would wish to see, and his appearance was not contrary to his nature, for he was a most affectionate dog. It was said at the time I had this dog brought to me, in 1892 , that a similar animal was to be seen at the Jardin des Plantes, in Paris.

This big dog is alluded to here in order to show what I have stated, that in other countries less civilized than our own, and where the flocks are likely to be disturbed by the attacks of various ferocious animals, the sheep dogs are of such a character as to be able to do full justice to their charges in the way of protection. 
In Scotland, many of the oldest natives consider that the deerhound, the collie, and the Scottish terrier, were one and the same animal originally; and in proof thereof point to the strange resemblance there is in the shape of head, expression, and ears of the three varieties. However, there is considerable difference in the colour and texture of the coats of the collie and the hard-haired terrier and the deerhound, the resemblance being between the two latter. Still, I have repeatedly seen types of the sheep dog with hard and wiry coats like that possessed by the deerhound, and something like two and twenty years ago, Mr. John Rigg, who then kept the Windermere Hotel, Westmoreland, had an extraordinarily good specimen, one good enough to win prizes at the ordinary shows at that time. Later, I have seen two or three dogs of similar type, though not so good-looking, competing successfully at sundry of the north country field trials.

Of the collie at the early part of this century, the Rev. W. Bingley, in his "British Quadrupeds," gives us an animal almost identical in type with what we have now. The illustration in the "Sportsman's Cabinet" is an excellent specimen of the old English sheep dog, rough and hard in coat, tail "semibob," or maybe it has been cut, and with lightcoloured eyes, that the artist, Reinagle, may have 
intended to represent "wall" or " china" eyes, a feature often found in this strain of dog, and one that is not supposed to be any detriment to him on the show bench.

There is no doubt that our collie or sheep dog is one of the most useful of the canine race, and within the last quarter of a century, he has likewise been made ornamental. The farmer and agriculturist can keep him without paying a licence to the State, as is the case with most other dogs, but care ought to be taken that the "unlicensed" sheep dog does not kill a rabbit or a hare, or assist his owner at a day's ferreting, else he at once becomes less distinctive, and, according to the working of the law, seven shillings and sixpence ought to be paid for the honour and pleasure of keeping him.

Although now as much a fancy dog as a worker, and the two qualifications have not yet been combined to any great extent, the collie is still numerous in the north of England and Wales, where the sheep are small, wild, and active, and the shepherd seldom leaves home without his dog or dogs at his heels. There is a story told of a tourist making inquiry as to the number of persons who attended the little church in one of the mountainous portions of the Cumberland lake district. "Why," was the reply, " t' last Sunday thar war ten cur dogs liggin' in 
't porch an' the churchyard," the inference to be deduced from the answer being that there were ten worshippers on the day in question, as each would be attended by his sheep dog- "cur," as he is usually locally known:

Such continued association between man and dog naturally tends to increase the sagacity and good sense of the latter, and so the shepherd's dog comes to be the most sensible of all dogs, but the animal kept for exhibition in this respect does not, as a rule, approach his working cousins. Stories of the former could be mentioned without number.

There is that of the Cumberland sheep-stealer hanged at Carlisle. Accompanied by a sheep $\mathrm{dog}$, he, in the daytime, frequented certain farms. Selecting sheep here and there, he pointed such out to his dog. At night the two went near the places, the dog was sent into the fields and drove out the sheep already chosen, which his dishonest master converted into mutton and then disposed of. Dogs have been known to drive sheep for many miles by themselves, and to distinguish between those that belonged to their master's flock and those of a neighbour's. The homing instinct is strong in the collie. A farmer friend of mine says a collie that belonged to him found its way from Norfolk back into Scotland. 
Hutchinson, in his "Dog Breaking," gives the following, which may be taken as being reliable as the names of the parties are given: "The late $\mathrm{Mr}$. John Bowstead, of Beck Bank, near Penrith, was in the habit of going every year into the Highlands of Scotland to purchase sheep, and in due course a man named James Johnston, who acted as shepherd for Mr. Boustead, was despatched to bring the sheep home. Many years ago, before railways became general, the sheep had to travel the greater part, if not the whole, of the way on foot, from two to three weeks being occupied on the journey, so that it was quite necessary for the shepherd to be provided with a good collie dog. On one of these occasions old Jimmy Johnston set off accompanied by his dog Yarrow, but whilst gathering up his sheep amongst the hills of Sutherland or Caithness, the two northernmost counties of Scotland, by some means or other he had the misfortune to lose his dog, and never saw him again during the rest of the journey. Some little time afterwards, however, while Mr. Bowstead's eldest son was standing by the kitchen fire, 'Yarrow' suddenly came running into the house, and wagging his tail jumped up at him, evidently delighted at having reached home again, young $\mathrm{Mr}$. Bowstead being equally pleased to see the lost dog once more, as it was a great favourite with him." 
As to the sagacity of the show collie, Mr. Rumball, of Birmingham, a well-known admirer of the breed, had a good-looking specimen that could play cards with considerable success. The common game of "Nap" was the one at which the dog excelled, and, indeed, he became so proficient as to be able to hold his own with anyone whom his owner challenged. I believe he played the game best when under the orders of Mr. F. Hinks, the well-known breeder of bull terriers, the sign by which it knew what cards to take, being a slight and almost imperceptible snap of the fingers. This dog, after being tried by a would-be purchaser, was sold to him for $£ 25$, on account of these accomplishments at cards.

There was a troupe of remarkably clever perform. ing collies at the Westminster Aquarium, London, towards the close of 1893 . These were all handsome sable and white dogs, doubtless bred from bench winners. After going through various leaping feats, walking whilst erect on their hind legs, on rolling barrels, skipping, \&c., one of them pushed on to the stage a fire escape. This was placed against the wall of a house supposed to be on fire. A child in its night-dress rushed out of the window and down the escape; the dog then ascended the ladder, went in at the window, and shortly re-appeared with 
a dummy baby in its mouth, with which it descended and placed in safety. The dog fell over on its side, evidently dead either through the smoke and fire or of its exertions. It was then placed on a stretcher, and eventually two other collies came on to the scene pushing an ambulance in front of them. The "fireman's" dead dog was placed thereon, and, to the tune of the "Dead March" from the orchestra, the curtain fell as the ambulance was being wheeled off the stage. The trainer of the dogs, "Professor" Duncan, had done his work well, and, throughout, the performance was one of the best of its kind I ever saw.

The first dog show that contained a class for sheep dogs was that at Birmingham in 1860 , when the late Mr. W. Lort and the late Mr. J. H. Walsh ("Stonehenge") awarded the prize, which they gave to a "pure Scotch bitch," exhibited by Mr. W. Wakefield, of Hurley, Warwickshire, who thus had the honour of taking the first show bench prize offered for a shepherd's dog. There were but five entries then, now in 1892 it is not unusual to find over 100 entries at our modern shows, and at Liverpool in 1892 the total reached 260; whilst at Ayr, in Scotland, in the same year, no fewer than 395 entries were made. Several of the dogs, in both cases, competed in more than one class, but 
at the Scottish show there were I53 sheep dogs benched, and in 1893 the entries were 287 , and the competitors I2 I.

Ten years after the institution of a class for them at Birmingham, there were but fifteen entries, and in 1870 , the second prize was awarded to a dog, Cockie, which the present generation will recollect as perhaps as good an all-round specimen of his race as was ever led into a show ring. He then belonged to Mr. W. White, Sherwood Rise, Nottingham, and I think with very slight exceptions, no modern collie of the prevailing type with any pretensions to excellence, is without some of the Cockie blood in his veins. He was not only a show dog but a worker, and that he looked both is manifest from the fact that he won prizes under shepherd judges and under the ordinary "circuit" judges alike.

He took the cup at Carlisle in 1870 , in a very strong class, farmer judges making the awards, and they all, as well as the spectators, said he was the best shepherd's dog they ever saw. Twelve years later, after some ups and downs, Cockie died peacefully at Great Bars, Birmingham, where he was well cared for by Mr. J. Bissel, who, a short time before, had purchased the poor dog for $£_{\mathrm{I}} \mathrm{O}$, this after he had been sold at a local mart for $£ 3$ only! 
Other good collies of the earlier days of shows were Mr. J. Holmes' Bob, Mr. Henry Lacy's and Mr. John Henshall's Mec; Mr. C. W. Wilson's Malcolm, and following them came Mr. S. E. Shirley's Shamrock. The latter was bred in the north of Ireland, but there is little doubt his ancestors came from Scotland; his sire is given as Mr. McCall's Shep, his dam Mr. C. Glasby's Bess. From Mr. Shirley's kennels also came Tricolour, Trefoil, and Hornpipe.

With the advent of the Cockie strain, and he formed a strain although his pedigree was unknown, and that of Mr. Shirley's, great improvement in the appearance of the collie became apparent. Trefoil was the sire of Mr. Bissel's Charlemagne (the most successful of all collies both at the stud and on the bench), from Maud, a daughter of Cockie's. The continuity of type handed down from these strains, points to their purity in the first instance, and one may well wonder what our present collies would have been had Trefoil and Cockie never had existence, or their excellence have remained undiscovered.

Charlemagne, a sable and white in colour, made his first appearance in public at Curzon Hall in I879, when, as a puppy, he received an honourable card only. Next year and for the four following years he won in his class and took the challenge cup 
likewise, nor was he beaten until the dark blackand-tan Rutland lowered his colours in I 885. Charlemagne was not much shown, so for an old dog he was comparatively fresh when he appeared at the Collie Club show in Holborn, in February, I 890, when he was once more given the prize as the best collie in the show. He died the following year, leaving behind a reputation as the most noteworthy collie of any time

Rutland, the dog that beat Charlemagne, had been bred by the Rev. Hans Hamilton, and after changing hands several times, he was purchased by Mr. S. Boddington, of Birmingham, from the selling, class at Warwick for $£ 5$, but just previously he had changed hands for half that sum. His new owner showed him well, and ultimately disposed of him to Mr. A. H. Megson, of Manchester, for $£ 250$.

From this time it seems that the collie gradually increased in money value, and as I write, a matter of a couple of hundred pounds for a perfect specimen would be considered by no means out of the way. At Manchester in I888, the gentleman who had bought Rutland, paid $£ 35^{\circ}$ at auction for a young dog called Caractacus, that his breeder and exhibitor Mr. J. J. Steward, of near Rugby, had entered for $£$ Ioo. This dog did little good afterwards, nor was he a good one. Again did $\mathrm{Mr}$. 
Megson open his purse, on this occasion paying, it is said, $£ 530$ to $\mathrm{Mr}$. Boddington for Metchley Wonder, a dog that I had engraved for "The Collie or Sheep Dog," published by Horace Cox in I 890. Wonder has been a remunerative investment in many ways, and as a fact, there is no better dog living at the present time, though others have been bought and sold for even higher prices.

The Messrs. Stretch, of Ormskirk, have been peculiarly successful with their collies, and in addition to those bred by themselves, they have displayed excellent judgment in the purchase of others. From Mr. Hamilton they obtained Christopher, a sable dog that did so well in the change of kennels that Mr. Mitchell Harrison, of the United States, paid the equivalent (in other dogs and cash) of $£ \mathrm{I}$ ooo for this handsome son of Metchley Wonder and Peggie II. Since then, Messrs. Stretch have sold individual dogs for several hundred pounds apiece-and, with one or two others, are considered about the most successful collie breeders of the present generation. They have had Ormskirk Memoir, Ormskirk Ormond, Ormskirk Golddust, purchased by them from Mr. Astley, who had claimed him for $£ 50$ at a small south country show, and many other dogs and bitches equally good. The extent of their 
kennels and the pitch to which collie breeding has reached, may be judged from the fact that it is said that during 1892 , something like two hundred and fifty bitches visited their dogs for stud purposes alone. And there are other notable kennels of collies at Manchester, Newmarket, Stratford-onAvon, and elsewhere, where results in a similar way, if not quite so extensive, are to the uninitiated somewhat astounding.

Whilst alluding to the prices of collies, I may say that the dogs have usually brought most money, still, sundry bitches have been sold for $£ 200$ apiece and more. Some of the best of this sex of late have been Ormskirk Dolly, Bleachfield Wonder, Bertha, Portington Beauty, Lady Christopher, Sefton Grace, Barwell Pearl, Matrimony, Parbold Phyllis, Ormskirk Memoir, Barwell Princess, but with so many high-class animals of both sexes now being shown it would be almost impossible to compile a perfectly complete list.

Messrs. Rae and Parsons have for a few years owned a particularly strong kennel of collies at Newmarket, and at the time of writing this in 1893, their Great Gun is by some judges considered the best $\mathrm{dog}$ at present before the public. He is a sable and white, a large, strong animal, whose expression might be improved, coat hard and profuse, 
which is not quite straight, but he excels several other notable dogs in carriage. In the spring of this year he beat Stracathro Ralph, a very excellent dog that had been successfully shown by his owner and breeder, Mr. Morton Campbell, of Dun House, near Montrose. The Scottish-bred dog had worked into the challenge class and was always an improving sort, and his opponent had also been the latter, for on previous occasions he had never found so great an honour in the prize lists. Stracathro Ralph is a son of Christopher, already mentioned.

But so many collies are bred for show purposes, that it is no wonder new faces of extraordinary merit appear to be cropping up every few months. Now, in I893, there are, no doubt, more good collies on the bench-many of them young ones -than had previously been the case. At the Manchester show in March, this was particularly apparent, and Mr. J. S. Diggle, of Chorlton, had a couple of bitch puppies there of very great merit. One of them, Parbold Phyllis, bred by Mr. Hugo Ainscough, of near Southport, who just at this time appeared particularly successful with his strain, is all-round perhaps the best collie bitch yet seen, a big one without being coarse, and a little soft and fluffy in coat, still in other respects she is almost perfect. However, she was but ten 
months old "when she made her debut-and early maturity I do not like to see. Still, she won the challenge trophy as the best collie in the show; beating Great Gun and all the other cracks, and was ultimately given reserve to a Newfoundland, who won the special awarded to the best nonsporting dog in the hall. Thus Phyllis was pronounced second best-a very high honour for a puppy to attain. Before this she had won several prizes at a collie show held at Birmingham.

Other of the more successful breeders are Messrs. Birch, Sefton, near Liverpool, their Sefton Hero being, perhaps, their crack, a winner of over one hundred prizes, a dog for which a large sum of money was refused, still I should place him a little lower in the scale than those previously alluded to.

In addition to the names given, the following have at one time and another obtained celebrity as owners of collies of special excellence, viz., Mr. C. H. Wheeler, Birmingham; Mr. R. Chapman, Glenboig; Mr. W. H. Charles, near Stratford-onAvon; Mr. H. Ralph, London; Messrs. Holmes and Halliday, Gainford, near Darlington; Mr. W. W. Thomson, Mitcham; Messrs. Birch, Seaforth; Mr. H. Ainscough, Parbold, Southport; Mr. H. Panmure Gordon; Miss L. Harvey, near Perth; Mr. H. Nimmo, Wishaw; Mr. B. R. Haigh, 
Portobello; Mr. M. H. Ashwen, Mr. T. Gilholm, and others. Nor must Mr. W. Arkwright, of Sutton Scarsdale, be forgotten, who for a time gave attention to producing the extremely handsome "mirled" collies, many of which had the china or wall eyes. These dogs abounded in character, and it was to be regretted that when the contents of Mr. Arkwright's kennels were disposed of at Aldridge's, the best dogs realised but small sums of money.

How admirably the collie is adapted as a companion we all know, and his sagacity in that department of life for which nature intended him, is equally well known. He is a different dog now when well attended and cared for, than he was when he had less value. That churlishness and snappishness which were prevailing features, appear to have almost entirely disappeared, and he does not rush out of the farmyard and seize the passing wayfarer by the calf of his leg, by the coat-tails, or elsewhere, as was his habit. Constant association with his superiors has improved his disposition immensely; he has quite risen to the occasion and to his aristocratic surroundings. His bark may now be taken to be quite as much a call of welcome as a cry of alarm or ill-temper.

I am not here going to write several pages as to the change in the appearance of many of the prize 
collies which has been produced through a craze for certain "points" or supposed excellences that are produced at the expense of others. This change is nothing new in other varieties of the dog. In the collie, unduly long heads, lean, narrow, and unintellectual, in many cases partaking of the greyhound type, or rather of that of the Borzoi or Russian wolf hound, have been sadly too prevalent. Indeed, these long-headed dogs were becoming so numerous that the cry raised against them had due weight, and I believe that in the future few or no such dogs will be seen coming on the show bench. A collie of all dogs should be sensible and sagacious. If he is so, he cannot in appearance be a fool-his character is stamped on his countenance - and many recent winners on the bench could be mentioned whose narrow foreheads, big eyes, and general appearance were indicative of idiocy rather than wisdom. Let us all hope, in our admiration for a noble dog, that what is said here and has been said elsewhere will prevent in the future a danger arising that might destroy the popularity of the collie.

Still more fault-finding. I do not know how it has been brought about, but somehow or other our collie in many cases arrives at maturity before he is out of his puppyhood-if such an expression may be used. At eight or nine months old he is well 
grown, his coat is profuse, if soft and fluffy, and he looks so well in the ring that the judge places him over older and better dogs. Still, he cannot gallop, he even walks badly; and when some eighteen months old or so, he has degenerated into a sorry object, and his show days are over. Few of the most successful dogs of modern times improve with age, as the old working collie and some of the earlier winners did. See Charlemagne, already alluded to, who beat all comers when eleven years old. Cockie, his grandsire, was a better dog at four years old than when he was less than half that age. Which dogs of the modern type will last so well as Mr. H. Ralph's Johnnie Norman, who, if a little grown in skull substance, was as full of collie character when we last saw him as he ever was. Someone stole this dog. Perhaps the three best dogs of the day that are likely to last are Metchley Wonder, Stracathro Ralph, and Great Gun. They may be seen winning perhaps two, three, or four years hence, and they are not puppies now. But of the hundreds of prize-winning collies now produced, with few exceptions their successes are but ephemeral, and it is quite as mischievous to breed for early maturity in a dog as it is to try to produce a head so abnormal in its length as to quite change the appearance of the unfortunate canine which carries it. 
It must not, however, be taken for granted that the collie as he is now seen, obtaining valuable prizes at our kennel exhibitions, is the exact counterpart of the dog met with on the sheep farms, and without which the shepherd could not get through his work. The former has been treasured for his beauty alone, and most likely for generations his ancestors had never known what it was to assist the farmer in his duties. So his descendants gradually drop out of the work, and when they do come to be trained, are not nearly so docile and intelligent as they would be had their progenitors been good workers.

We occasionally do see, at the various trials with sheep held in different parts of the country, a handsome dog that is a fairly good worker, but such is the exception, and I am sorry to write that; so far as the shepherd's work with the collie is concerned, the handsomest dogs are usually the worst workersat any rate in public. It was, however, gratifying to find at the Llangollen Trials in I 893, one descended from bench winners proving successful. This dog, Mr. R. S. Piggin's Ormskirk Charle, won the allaged stake there in excellent style, beating pretty well all the cracks in the country, and afterwards was awarded the Special as the handsomest dog on the ground. Ormskirk Charlie, bred by Mr. Richard 
Thornton, of Winmarleigh, Lancashire, and is by Christopher from Prim of Winmarleigh. The dam of Charlie was a good working bitch, and her pedigree goes back to the Trefoil blood on one side. Her owner considered Prim of Nateby, her granddam, as all round one of the best working bitches in Lancashire, being equally good with sheep and cattle. With the latter her intelligence was such that, when sent to bring in the cows to milk, she always separated the young from the old stock without assistance. Evidently Charlie has inherited some of her cleverness.

The collie has had several clubs established to increase his beauty and his popularity, and that they have been successful in so doing goes without saying. Such clubs have hitherto been sadly negligent as to the working merits of the dog, and any improvement that of late years may be noted in the latter must be set down to those associations in Wales, the North of England, and elsewhere, that annually hold competitive trials. The first meeting of the kind took place at Bala in North Wales in I 873 , and since that time such have been of annual occurrence, and in some districts they are received with great favour by the farmers and the shepherds.

No more interesting sight can be imagined than on a fine day to see a number of highly-trained 
shepherds' dogs one after another driving a little flock of sheep in a perfect manner. The country air is bracing and healthy on the hill sides, all the surroundings of the gathering are thoroughly rural and invigorating, and the good humour of the owners of the competitors appears in marked contrast to the jealousies so often present at competitions of other kinds. In 1889 , on a Royal visit to Wales, Her Majesty expressed extreme gratification with the working of the Welsh dogs that were given a trial in honour of the occasion.

As something ought to be said as to the management of such trials, I cannot do better than quote from what I have already written on the subject, and which will be found more fully described in Chapter VI. of the "Collie or Sheep Dog," and already alluded to.

"The arrangements are simplicity itself, and with two or three good managers undertaking the work in hand, the cost of the preliminaries is not great. In the first instance, suitable ground is to found. Of necessity this need not be in one field, but must be of an extent-of say, extending in one direction about half to three-quarters of a mile by about a quarter of a mile in breadth. From a note made by me at the time, I find that at the trials held at Gilsland, near Carlisle, in I885, the dogs had to 
drive their sheep something over 800 yards, and the trial ground covered about 90 acres. The latter, of course, not including the portions occupied by the spectators. Here, on our wild, bleak fells of Cumberland, the space to be obtained was almost unlimited. As circumstances occur, these estimates may be extended or decreased at will. Having secured such suitable ground, the next thing is to draw out a plan denoting the course over which the dogs have to drive their sheep, the positions where the worker of the dog, the judges, and officials are to stand, the location of the spectators, and the place where the pen is erected into which the competitors have to drive their flocks.

"The course is indicated by a succession of flags placed at intervals, on the far side of which the dogs drive the sheep, the time occupied and the manner in which the work is done being placed to the credit or otherwise of the competitors. The sketch on the opposite page will assist to convey an idea as to a plan of the ground.

"The sheep are liberated near A, the shepherd standing at $B$ sends his dog to the sheep, which are to be driven in the direction indicated by the arrows on the far side of the flags to $\mathrm{D}$, a pen of hurdles into which the sheep have to be driven. . The 
judges and officials stand at $\mathrm{C}$, a position from which they can observe all the work.

"This trial ground should not be level like a racecourse; it is better more or less undulating; with a footpath or two running across; a dry burn or ghyll to pass over; a gap or opening in a hedge or fence to be driven through. Roughish land is best of all, even if it lay along a hill side, a commencement of

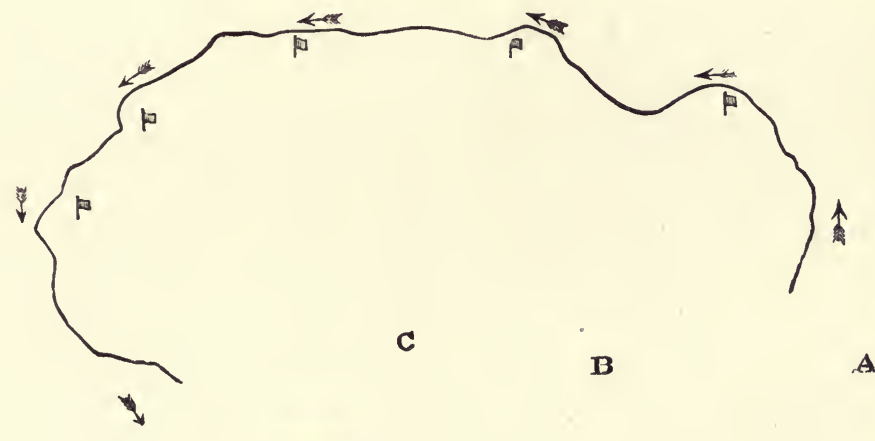

the task being to drive the sheep up the incline, and away from the shepherd. Then along the outside or far side of the flags to the boundary flag, which must be properly rounded, and so on the far side of other flags on the return journey, to three hurdles forming a pen, with the fourth hurdle away, leaving an opening. Through the latter the little flock has to be sent, the worker of the dog being allowed to 
assist as he likes, without, however, touching the sheep. Until now the shepherd has worked his collie from the spot where it was originally let loose, and sent to find the sheep which had been separated from a flock inclosed and out of sight. Were the whole of the sheep in view of those to be driven the latter would make back to them, and totally refuse to be taken as intended.

"As to the sheep: These ought to be either of the Welsh breed, the black or of some grey-faced Scotch variety, or Herdwicks, taken from various flocks. Each dog drives three different sheep, two being from one farm, and the third from another. This arrangement makes the task more difficult, the sheep not knowing each other, and when ont: breaks away, considerable skill is required to get it to its companions again. Sometimes the latter cannot be done, so the worker of the dog by whistling, calling, or by movements of the arms, lets his favourite know that the two must be driven to the one. This may prove successful, and by order the sagacious collie continues his task. Possibly the sheep may run away entirely, and, followed by the competitor, gallop until the latter is out of sight and out of hearing too. Then, after a tedious wait of a quarter of an hour or more, in the far distance the three sheep and their canine driver may be seen, 
the latter bringing his charge back to his owner, irrespective of course to be followed, or anything else. All he knows is that his duty is to fetch the sheep, and this he does.

"Another difficulty comes when one of the three sheep cannot move as fast as the others, and, being hard pushed, ultimately gives up entirely and lies down; in which case the best $\operatorname{dog}$ in the world cannot make it rise again until thoroughly rested and so inclined. One batch of sheep may almost of themselves go the course, and require little driving by the dog, whilst: au contraire, another lot may be just as stupid and wayward, willing to be taken in any direction but the right one. Sometimes the collie is unable to make a start at all through his perverse flock separating and trotting away in different directions immediately they are loosed from the liberation pen. Again the competitor may perform his driving task admirably, but is quite unable to consummate his work of making the sheep enter the pen at the end of the trial. Repeatedly at this penning the best work is shown, and the patience of the dog must be well supported by that of the shepherd.

"To be successful at these trials the dog must be sagacious, well trained, quick of hearing, and sharp in his sight, patient, and have a peculiar 
power in commanding his sheep. That some collies possess the latter important qualification to a greater degree than others I am confident, and, although there is a considerable amount of good or bad fortune in obtaining an easy, or the reverse, batch of sheep, still the very best dogs appear to make even the most stupid little "Welshman" or "Scotchman" know that no larking will be allowed, and that they must go exactly where the dog wishes. This is a power similar to that possessed by some men over animals-the performer in the menagerie over his lions or tigers to wit-and in breeding collies for working, I should certainly use those dogs which possessed this extraordinary and unusual gift to the greatest extent. A barking dog is useless at such meetings, and one that loses its temper, rushes at and attempts to bite his sheep is equally (or sooner) put out of the stake.

"In training or practising a collie for work of this kind, care must be taken that the lessons are given in both directions, i.e., the dog be taught to work from left to right and vice versa. I have seen an otherwise good dog make a wretched performance when it came to compete on a course which lay in a direction contrary to that in which its early lessons. had been given. The most difficult thing to teach is to make your dog drive the sheep away from you 
-any duffer almost will bring them up to you, but taking them away altogether for a half a mile or so up to a certain point, and then turning them towards the home journey, requires great skill, more so than is required at the pen when the trial is terminating."

So much for trials with sheep, which I should like to see adopted in every county, under proper and reasonable management and conditions. But I do not like to see the rule which is in force in many places, where the "shepherd working his dog is compelled to hold a rope in his hand, which allows him to go so far and no further, under pain of disqualification. If without such a silly rule a committee cannot make the handler keep within a prescribed area, they are certainly not fit to occupy the position they are supposed to so well grace.

At the Llangollen meeting a class is provided in which the shepherd has to work a brace of dogs together. Two lots of sheep are first gathered, then separated again, the one lot of three, marked with " ruddle,", having to be first secured, then the other lot, which numbers half a dozen, are to be driven within the hurdles in a similar manner. Personally I have not seen such interesting work when the two run together as I have done when working separately. 
I have sometimes wondered why the management at the Birmingham show, held three weeks or so before Christmas each year, does not provide special classes for sheep dogs that have won prizes or performed creditably at trials with sheep. This is the only one which gives special classes for field trial winning pointers and setters, and it would certainly be a feather in the cap of the executive were they to encourage working collies in a similar manner. If the committee of a dog show cannot afford to do this, why does not one of the much vaunted collie clubs come to the rescue? Talk to the members of such societies, and they will dilate upon the excellence of their own particular strain, so far as the work connected with shepherding is concerned; but I am sadly afraid that for the most part such is merely talk, and the real purpose of the collie clubs is to provide prizes for their own members, whether the dogs which win them are of any use in the field or not.

At the show at Curzon Hall, in November, 1893 , there were a lot of useful collies on view, and I was much struck with the awards, which, except in about one solitary instance, were made to dogs which from their appearance of docility and intelligence might be as useful in the field as they are handsome in the judging ring. 
As to the points and description of the collie, both the Collie Club of England and the Collie Club of Scotland have formulated their own scales and descriptions, and as they differ somewhat, both are reproduced here.

\section{The English Club's Standard.}

The skull of the collie should be quite flat and rather broad, with fine tapering muzzle of fair length and mouth the least bit overshot, the eyes widely apart, almond shaped and obliquely set in the head; the skin of the head tightly drawn, with no folds at the corners of the mouth; the ears as small as possible, semierect when surprised or listening, at other times thrown back and buried in the "ruff."

The neck should be long, arched and muscular, the shoulders also long, sloping, and fine at the withers; the chest to be deep and narrow in front, but of fair breadth behind the shoulders.

The back to be short and level, with the loin, rather long, somewhat arched, and powerful. Brush long "wi' upward swirl" at the end, and normally carried low.

The forelegs should be perfectly straight with a fair amount of flat bone, the pasterns rather long, springy, and slightly lighter of bone than the rest of the leg; the foot with toes well arched and compact, soles very thick.

The hind-quarters, drooping slightly, should be very long from the hip bones to the hocks, which should be neither turned inwards nor outwards, with stifles well bent. The hip bones should be wide and rather ragged.

The coat, except on legs and head, should be as abundant as possible; the outer coat straight, hard, and rather stiff, the under coat furry and so dense that it would be difficult to find the skin. The "ruff" and "frill" especially should be very full. There should be but little "feather" on the fore legs, and none below the hocks on the hind legs.

Colour immaterial. 
Symmetry.-The dog should be a fair length on the leg, and his movements wiry and graceful; he should not be too small, height of dogs from 22 inches to 24 inches, of bitches from 20 inches to 22 inches.

The greyhound type is very objectionable, as there is no brain room in the skull, and with this there is to be found a fatuous expression, and a long powerful jaw.

The setter type is also to be avoided, with its pendulous ear, full soft eye, heavily feathered legs, and straight short flag.

The smooth collie only differs from the rough in its coat, which should be hard, dense, and quite smooth.

\section{Scale of Points.}

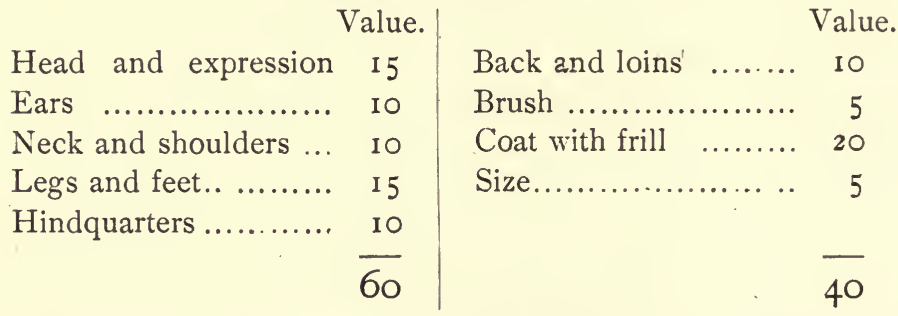

Grand total, 100.

Note.-Point judging is not advocated, but figures are only made use of to show the comparative value attached to the different properties; no marks are given for general symmetry," which is, of course, in judging, a point of the utmost importance.

\section{The Scottish Club's Standard.}

\section{Rough-Coated.}

Head moderately long in proportion to the dog's size, covered with short soft hair. Skull flat, moderately wide between the ears, and gradually tapering to the eyes. There should be a very slight elevation of the eyebrows, and very little stop. 
Muzzle of fair length, tapering to the nose, which, whatever the colour of the dog, should be black. The teeth, which are white and of good size, should not be over nor undershot. Both are faults, the latter the greater of the two.

Eyes, of fair size, but not prominent, are placed rather close together, and set obliquely in the head, which gives that cunning foxy expression so characteristic of the breed. Colour, any shade of brown, the darker the better, yellow eyes being a great fault. Dogs of a mirled colour should have a mirled or china eye, and sometimes both eyes are of this colour.

Ears small, placed rather close together at the top of the head, covered with short soft hair, and carried semi-erect when at attention; at other times thrown back, and buried in the frill.

Neck long, arched, and muscular.

Body rather long than short, ribs well rounded, chest deep and narrow in front, but of fair breadth behind the shoulders, which should be oblique. Loin rather long, and sightly arched, showing power.

Legs.-Forelegs straight and muscular, with a fair ämount of flat bone, the fore-arm moderately fleshy, the hind legs less fleshy, very sinewy, and hocks well bent. Pasterns long and light in bone. Feet oval in shape, the soles well padded, and the toes well arched and close.

Tail, moderately long, carried low when the dog is quiet, gaily when excited, and almost straight out when running.

Coat.-This is a very important point. The coat, except on the head and legs, should be abundant, the outer coat harsh to the touch, the inner coat soft and furry, and very close, so close that it is difficult on parting the hair to see the skin. The hair very abundant round the neck and chest; this is termed the frill. The mask is smooth, the fore-legs slightly feathered, the hind-legs below the hocks smooth. Hair on tail very profuse, and on the hips long and bushy.

Colour.-Any colour.

Size.-Dogs $2 \mathrm{I}$ inches to 24 inches at shoulder, bitches 2 inches less.

Weight.-Dogs $45 \mathrm{lb}$. to $60 \mathrm{lb}$., bitches $40 \mathrm{lb}$. to $50 \mathrm{lb}$. 
General Appearance.-A lithe active dog, with no useless timber about him, his deep chest showing strength, his sloping shoulders, and well-bent hocks speed, and his "bawsint" face high intelligence. The face should bear a sharp, doubtful expression. As a whole, he should present an elegant and pleasing outline, quite distinct from any of our other domesticated breeds, and show great strength and activity.

Faults.-Domed skull, high peaked occipital bone, heavy pendulous ears, full soft eyes, heavy feathered legs, short tail.

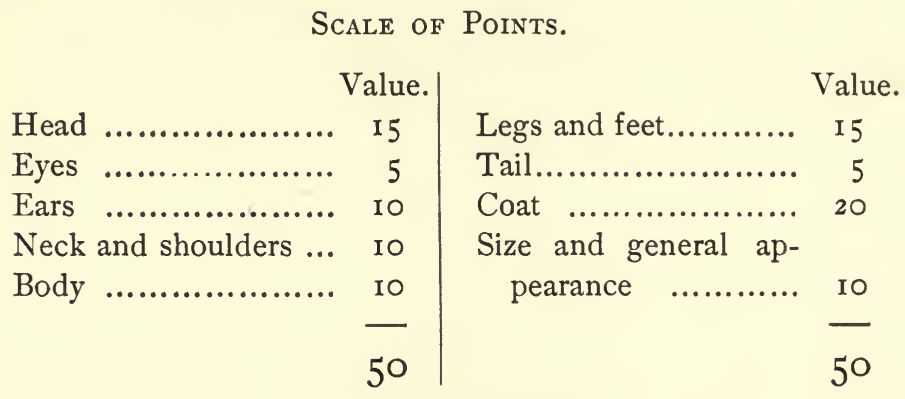

Grand Total 100. 



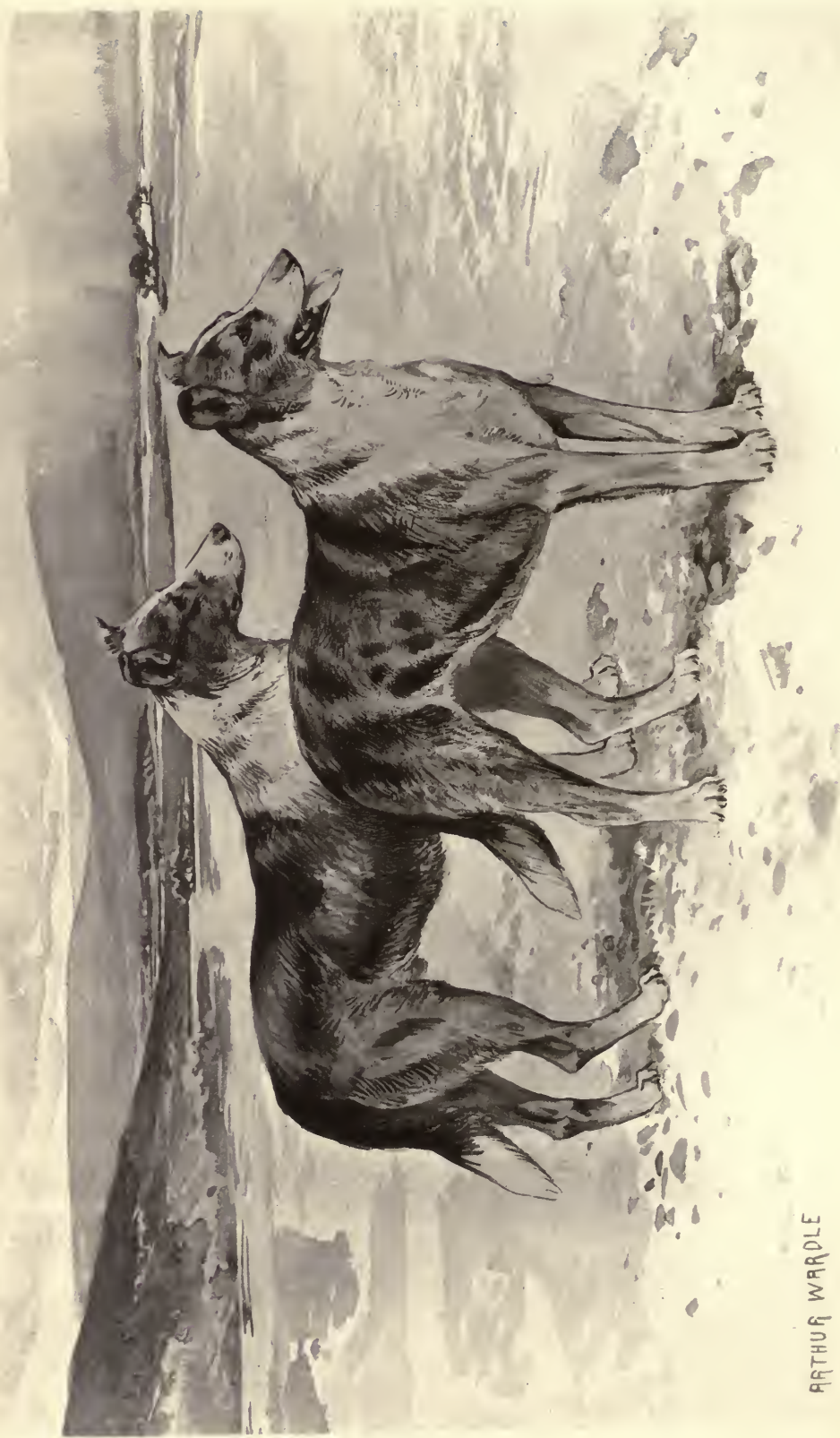




\section{CHAPTER V. \\ THE SMOOTH-COATED SHEEP DOG.}

THIS variety of the collie has mostly been produced in the north of England. Being less cumbersome in formation than the dog previously written about, it is better adapted for work on many of the hills, especially those where rocks and rough stones are more plentiful than heather and bent grass. The smooth sheep $\operatorname{dog}$ is a most active animal. I have seen one that could catch a hare single handed, and in intelligence and sagacity he is quite equal to his rough-coated cousin.

Some of them make excellent drovers' dogs, and at the time of writing, one of the very best cattle dogs in the London markets is a smooth sheep dog with half of its tail cut off.

One of the first dog shows to provide a class for this variety was the gathering that annually takes place at Darlington. This was in 1870 , and from that time until 1892 the best classes of smooth dogs were to be found there. The farmers round 
about prefer him to any other, and in the Weardale district many homesteads have their own strain, which, as well as being good-looking, are second to none in the performance of their duties with sheep. In Northumberland and in the districts both sides the Border, smooth collies are to be found in abundance, and when a specially good specimen appears at any of our southern shows, it may be taken for granted that it originally came from the north.

Perhaps the smooth collie. would be more popular were he less difficult to breed to perfection. In some strains the trouble comes in getting the coats sufficiently smooth, especially in many of the black and white Northumbrian dogs, that appear to me to be quite distinct from any of the other varieties. The black on such specimens has a tendency to appear blue when seen in a certain shade, the coat is rather longer and more open than is actually desirable, and therè should not be even the slightest tinge of tan or brown-a blue-black dog with more or less white on his breast, neck and feet. From time to time Mr. A. Hastie, of Newcastle, has shown excellent specimens of this strain, which he usually purchased in the northern cattle markets he is in the habit of attending.

Perhaps one of the best smooth collies I ever saw appeared at some of the local shows in Westmore- 
land about twenty years ago. This was a peculiarly coloured brown bitch with a natural bob-tail. She belonged to a butcher, and was quite as good in work with either cattle or sheep as her appearance would imply. No sheep dog I know now, had nearly the character or expression she possessed. Mr. W. W. Thomson about the same time had an excellent black, white, and tan called Yarrow; Mr. T. Swinburne's Lassie was another good one of similar type. More recently Mr. W. Arkwright had a bitch called Melody, which many good judges considered the best of her race, and Mr. E. Hutton, of Pudsey, near Leeds, has from time to time had animals of this variety above the average in quality. More recently Mr. A. H. Megson has had some good specimens. The best of these is undoubtedly Heatherfield Tip, who is by many persons considered the best of his variety yet shown. Anyhow, he has not met defeat up to the time this was written. He was pupped in August, I 892, is a dull sable and white in colour, possesses a coat neither too short nor too long, his ears and expression are very good, and all round he is most symmetrical and characteristic.

To my mind, the handsomest smooths are those " mirled" or "marbled" in colour, with "china" or wall eyes. This colour is sometimes intermixed 
with brown, giving an almost tortoiseshell - like appearance which, if rather odd, is extremely pleasing to the eye. An impression prevails in some localities that the vision of these "wall" or "china" eyes is stronger and more powerful than in the eyes of ordinary colour, and that they never contract cataract or opthalmia or other diseases of the optirs. Maybe this is an "old wife's tale," and its truth or otherwise will be difficult to determine at any rate I can say that I have not hitherto come across any china-eyed dog that had any particular disease of the eyes. The best "mirled" specimens have been owned by Mr. H. Mapplebeck, whose Fan was for a long time quite invincible on the show bench; Dr. James, Mr. John Powers, Mr. Megson; and Mr. F. Hurst, Heatherfield, Knutsford, have, perhaps, had the best collections of smooth-coated collies ever brought together.

Quite as intelligent as his rough-coated cousin, he is less popular because he is more difficult to produce in perfection, and when produced is not worth so much money. A County Court judge not long ago awarded only $£$ IO as damages for the loss of a dog which, by his intelligence, had probably saved his owner's life, and had young Gough when he was lost on Helvellyn had such a sensible animal with him, instead of a common little terrier, 
whose stupidity has been immortalized in verse, perhaps neither Wordsworth nor Scott's pathetic poems would ever have been written.

Mr. Ridley, a young farmer of Wolsingham, in Durham, was out on the fells looking after the sheep. Unfortunately he slipped and broke his leg. In great agony and unable to move, he lay at the foot of a crag for a considerable time in the expectation of someone approaching who could hear his cries and so render assistance. No one came. His faithful bitch Lassie lay by his side. Night was coming on; the young farmer thought it would be unpleasant and dangerous to lay out on the fells all night, so he attached a note to his dog's neck and bid her "Away home, Lassie." Although several miles from the farm, Lassie required no second order, and quickly was making a great to-do in the kitchen. Then the paper on her neck was noticed, and in due course assistance was sent to the injured farmer, who was rescued from an exposure that might have caused his death. And when Lassie, who was a show dog as well as a sensible creature, was stolen from some small exhibition, whose secretary was sued for her loss, the County Court judge gave Mr. Ridley $£$ IO as the full value of his dog. The original claim of $£ 50$ was, I take it, under the circumstances, an extremely moderate one. 
The smooth-coated collie differs only from the rough variety in coat, which in the former should be hard, dense, and quite smooth, so no special scale of points is required for him, but in judging care must be taken that the prizes are awarded to really "smooth or short-coated" animals that have no long hairs or feathers on their hind quarters and stern. I fancy it is there and on the neck that the cross with the rough-coated dog would become most apparent; and instances have been known where attempts have been made to win prizes in classes devoted to the smooth variety with rough-coated specimens in the process of "moulting," assisted by the trimming operations of their owners. A smoothcoated tri-colour is a handsome companion, though unfortunately not a fashionable one. 



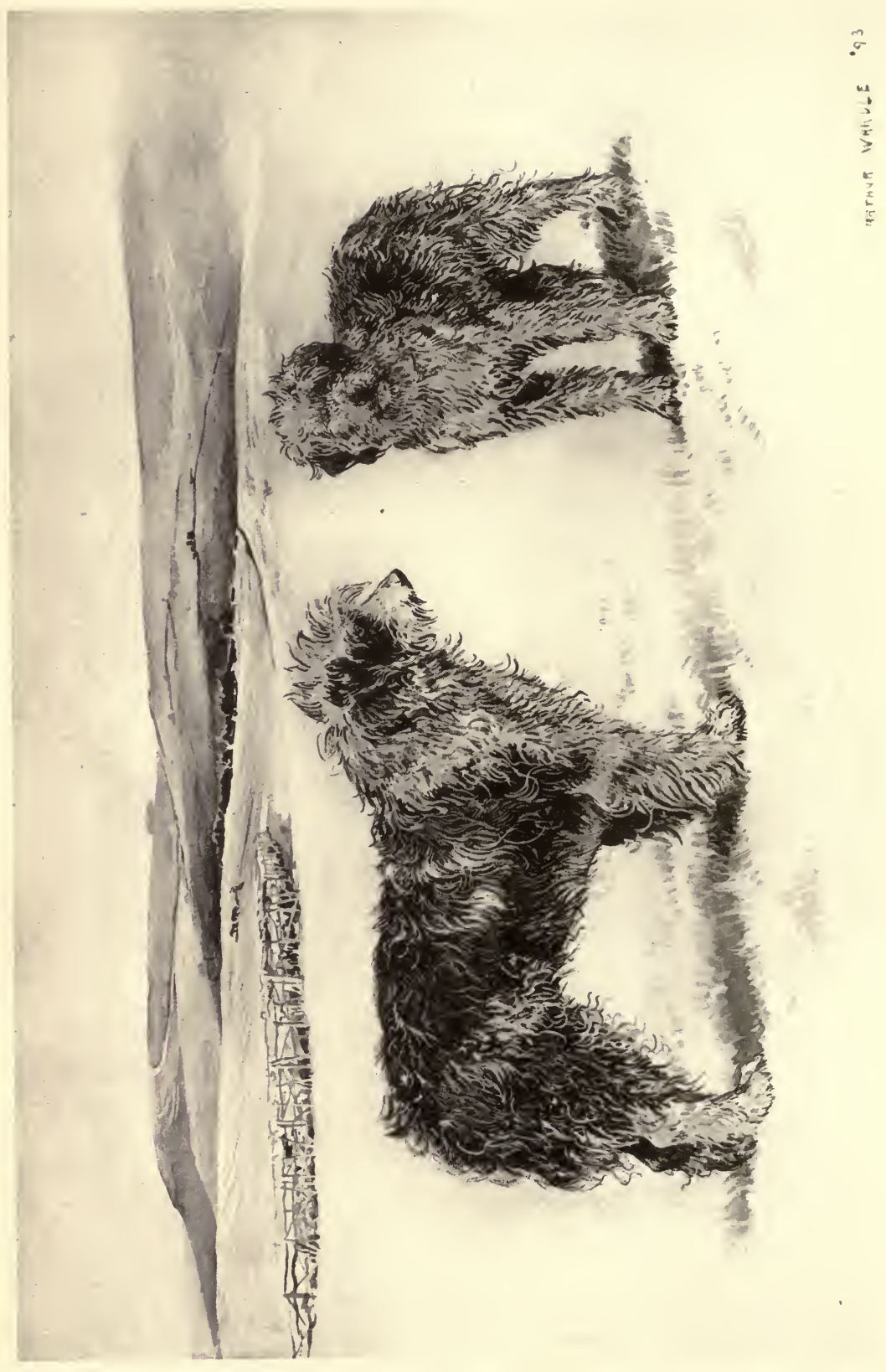




\section{CHAPTER VI.}

\section{THE OLD ENGLISH (BOB-TAILED) SHEEP DOG.}

OF late years there has been a strong attempt to re-popularise this quaint and representative creature, a dog that always reminds me of one of our shaggy ancient British forefathers we see in picture books. The collie clubs have not acknowledged him as one of their race at all, so it has the honour of having a club of its own formed by some few admirers of the variety who believe there is no other $\operatorname{dog}$ in existence with even half the good qualities possessed by their special fancy.

A useful creature in his way, with a certain amount of rugged, unpolished beauty, his disposition is often surly, he frequently prefers a fight to his ordinary agricultural duties, and although a faithful enough companion to his master, is likely to be ill-tempered with strangers, and will not stand quietly and be rebuked by others.

Possibly he is an older dog than the ordinary collie, nor has modern fashion as yet changed him 
so much as it has other dogs. Reinagle's picture in the "Sportsman's Cabinet," published very early in the present century, is a capital example of what the dog is to-day, and such a one as there pourtrayed, would now, if alive and in the flesh, take the highest honour at any of our leading shows.

In Scotland there is an old-fashioned sheep dog of the same sort called the "Highland or Bearded Collie," and although he is by no means common, classes are sometimes provided for him at local shows, and they usually attract a considerable entry. I certainly agree with the author of the "Dogs of Scotland," when he says that the two varieties as found in Scotland and England are identical, and if the former is usually seen with a long tail, it is only because his owners have refused to amputate it in order that it might have a so-called " bob-tail."

It has been said that the variety of old English sheep dog was originally of Welsh extraction. The indigenous Welsh dog is a little smoothcoated, mirled or tortoiseshell - coloured, wall-eyed creature, smart and active for the work on the Welsh hills, where the heavy, cumbersome "bobtail" would be out of place. As proof of the alleged Welsh origin of the bob-tail, it has been adduced that Mr. R. J. Lloyd Price, at Rhiwlas, Bala, has had a strain on his estates for some generations. 
So he had, but unfortunately for the argument of those who say the true Bob-tail is Welsh bred, such dogs were originally brought from the Southdowns, in Sussex, by Mr. Edward Lloyd, grandfather to the present Rhiwlas squire.

As a fact, the old English sheep dog is pretty common in almost every county in England, but is most often found as the dog of the farm in the midland and southern counties, and as assistant to the drover in the metropolitan and other cattle markets of our large centres. $\mathrm{He}$ is an excellent cow dog-not so good for sheep, and were the latter to turn and face him and stamp their little feet in anger at his shaggy face, as the Welsh and Scotch sheep often will do, quite as likely as not the "bob-tail" would use his teeth on the foolish creatures. In no degree has he the patience of the true collie, an attribute in which the latter excels above all others of the canine race.

One of the peculiarities of these dogs is that many of them are bred either without tails at all or with very short tails-tails ready docked in order to spare the mutilating process which their owners would have to undergo. It has been considered that these puppies born without tails are the purest bred, but this is another fallacy, for both "tails" and "no tails" are usually produced in the same 
litter of puppies. Then other admirers of the race say that they can tell a natural bob-tailed dog from one that has been "curtailed" by the manner in which the former "wags his hind-quarters" when pleased. He has no tail to wag, so he wags his buttocks say they. There is no doubt that the tails can now be so docked that not even the most skilful practitioner could, from outward examination, discover that such an operation has been performed.

Dr. Edwardes-Ker, of Woodbridge, Suffolk, is the great authority on the variety, he having bred and kept it for over twenty-five years, and at the same time made himself thoroughly acquainted with all the specimens to be found in his locality which, with portions of Dorchester, perhaps produces more old English sheep dogs than any other part of the kingdom. His opinion on experience as follows will no doubt be valued. He believes that

"Many hundred years ago, when our island was principally primeval forest, with but few clearings, it must necessarily have been infested with wolves, bears, and the lesser British carnivoræ, and to protect the flocks and herds it must have been requisite to have a large and powerful dog, able to cope with such formidable and destructive foes, able to undergo any amount of fatigue, and with 
a jacket to withstand all viciscitudes of weather, for his avocation was an everyday one; day and night, and in all weathers, was he watching and battling with heat and storm and marauding foes. What other dog but the old English sheep-dog possesses attributes necessary for the multifarious duties urged upon such a business?

"There we find the sagacity, the activity, the enduring strength, the dauntless courage, and the weatherproof jacket combined to such a degree in no other British dog. His origin is lost in the dim obscurity of buried centuries. To my mind his antiquity and concentration of purity of strain are fully shown in the fact, that if there be a strain of old English sheep-dog blood many generations back in any breed of dog, a typical specimen will every now and again show itself in the litter produced by utterly dissimilar breeds, no matter whether it be a retriever, lurcher, spaniel, or cur of low degree. Apparently not one drop of sheepdog blood for generations, and yet there is the unmistakable youngster-sometimes tailless, more often with a three-inch stump-brought into the world jet-black, with his characteristic white markings, and in a few weeks, chameleon-like, he gradually assumes the silvery-lilac livery of his ancient British ancestors, and makes his bow to 
the public as a pigeon-blue and white English sheep-dog, 'breeder and pedigree unknown.'

"With regard to the sagacity of this breed I consider it has few equals, and certainly no superior. In a large dairy farm I know of, there is a dog which will fetch up individual cows as they are required to be milked, distinguishing those which he has already fetched up, and after being milked are allowed to mix with the rest of the herd. When quite a lad I remember seeing an old grizzle and white sheep dog lying outside a farmhouse here in Suffolk, which three weeks or a month before was purchased in Dumfries; he worked a herd of bullocks all the way from his Scottish home to the eastern corner of Suffolk by road. After remaining comfortably for a fortnight in his new quarters, one day he was missing, and no tidings could be gleaned of him in the neighbourhood; and no wonder, for within the week his Suffolk purchaser received a letter informing him the old dog was safe back in Dumfries. This incident occurred to Mr. Edmund Tye, of The Moat Farm, Dallinghoo, Suffolk, who was my informant.

"As to the size of the original breed, I cannot help thinking he was a much larger dog than is seen nowadays. They have a dwarfed appearance; they are all 'little big 'uns,' and to obtain that 
characteristic there must have been the size sometime or other. And I confess I prefer the big ones, they have a grander appearance, a big blue and white dog of twenty-five inches catches the eye, and he can carry a heavy coat without looking like a smothered Yorkshire terrier or a door-mat-like Isle of Skye. Shepherds prefer the little ones, why? because they do not eat so much, and can dodge in and out of the furze bushes after rabbits. These men do not want sheep-dogs nowadays, they prefer whippets. The well-known dog, Sir Guy, who in his day was almost invincible on the show-bench, was once sold for two shillings because he fell head over heels over a rabbit: and to my idea that old dog, when in full coat, was the grandest sheep-dog in existence.

"An old English sheep-dog's coat should be shaggy, and all I can liken it to, is to that peculiar style of growth of hair frequently seen on a clodhopping countryman's head - in a word, shockheaded: one lock growing this way, and another that way; no curl, but a sort of head you could. wipe your boots on!

"Suffolk has produced most of the best show specimens of late years - to wit, Sir Guy, Sir Lucifer, Sir Lancelot, Mayor of Newport, Blue Ruin, Welsh Sensation, Welsh Marvel, Dame 
Dorothy, the American Dame Judith. Dame Margery, bought in Norwich Market sixteen years ago for half-a-crown, was the dam of the last Olympia Cup Winner, Sir Caradoc, and granddam of Sir Cavendish. Nellie II. is another sterling good bitch, great in size and style, a trifle soft in coat, but there is no poodle resemblance; her sire and dam were sheep-dogs of the type beloved by drovers, long and strong, and rough in body and mind. No doubt the best bitch of the variety we have at present is Dr. Locke's Gwen, a grey or blue and white, with a correct coat, which is, however, somewhat spoiled by being overgroomed for show-bench purposes. She has won a great number of prizes at most of our leading shows. For colour I prefer the pigeon-blue, not washed out, but well defined, standing out clearly against nice white markings, and, if possible, a wall-eye or two; but any shade of grizzle is equally correct. Sables and brindles and blacks are an abomination! Dogs twenty-four or twenty-five inches, or larger if possible. Bitches as big as one can get them, both sexes being strong and masculine in appearance, with length and strength, well knit, but not cloddy like guinea pigs; at the same time size should not weigh against type and quality. The more hair on the jaws the better; I mean hair, too, not wool. 
"I remember, as quite a boy, that the generality of old English sheep-dogs were grey or blue in colour, with white feet, and white head and neck. Nearly every drover had one, and every shepherd, for we had no collies then. An old drover who died here (near Woodbridge) in 1889 , at a very great age, named Chuffy Plant, told me that my dogs were the right stamp, but they were 'little ratdawg things'; too much quality; were not big enough or strong enough. I could not argue with the old man, as I felt he was an authority, but I explained to him that I had to breed for the showbench. Whereupon he anathematised the showbench with this remark: 'Drat it all, ye can allus breed minnifers; dround them and rear the big 'uns!' Minnifer or miniver signifies the weasel, but is a term applied in Suffolk to any small or weedy specimen of animals."

Sir Cavendish, now the property of Dr. Locke, of Tenby, but bred by Dr. Edwardes-Ker, I consider the handsomest and best of his breed hitherto seen; moreover, he possesses to a remarkable degree all the attributes required to approach perfection. He may well be considered the typical specimen of his variety, and, as such, particular trouble has been taken to obtain his full description, which, in combination with the general one 
already given, will enable those interested to know exactly the sort of animal required.

Sir Cavendish is a pigeon-blue and white dog, with a white collar and white blaze, $23 \frac{1}{2}$ inches in height at the shoulder, $5^{2 l b}$. in weight, with very small flat ears, almost entirely buried in coat, which is long, thick, and shaggy, free from either straightness or curl. It is I I inches long upon his loins and hind-quarter, whilst his face and legs are evenly and equally clothed with hair, the front of the legs carrying as much coat as the back part of the same. His tail is very short, natural stump, and when he "wags" it, he does so vertically, not horizontally, which his breeder says is a peculiarity he has looked for in vain in any other strain. His sire, Sir Caradoc, is well known as a pigeon-blue and white dog of large size, rather soft in coat, but showing remarkable character; both he and his son inheriting their beautiful colour and sheep-dog characteristics from old Dame Margery, who was also a "natural bob." Her strain is remarkable as most of the dogs and bitches bred therefrom possess double dewclaws upon one or both hind legs.

One other interesting fact remains to be told with regard to the way Dr. Ker hit off the pigeonblue colour. He had been breeding blue grizzle 
with blue grizzle for several years, hoping to produce the coveted pigeon-blue, but to his chagrin the puppies came darker with each succeeding generation, and smaller likewise. The thought then struck him of Jockey to get the size back-never dreaming about colour. Jockey was then mated to Dame Margery, and she bred two dog puppies at fourteen years old. One of these was of the long-coveted colour-he became Sir Caradoc; whilst the other was nearly white, with blue ears and a tan cheek.

A great portion of the above was printed in my book on the collie, but since it was published a couple of years ago, few really good specimens of the old English sheep-dog have appeared on the show bench; nor has the character or style of the dog been altered. The best of these have been Mr. Weager's Wall-eyed Bob and Brave Tory, Messrs. Birch's Invincible, Dr. Ker's Dame Caven- . dish, Mr. A. H. Megson's Sir Tatton, Mr. Freegard's Mayor of Newport, and Dr. McGill's Watchboy (one of the finest dogs I ever saw of the kind, some think him too big). Mr. T. E. Rees, Cardiff; Mr. R. Abbot, Norfolk; Mr. D. P. Thomas, Pontypridd; Mr. Freeman Lloyd, London; Mr. J. Thomas, London; Mr. A. C. Jackson, Bath, have also from time to time exhibited excellent specimens of the old English sheep dog. 
The following is the scale of points allowed in judging this variety :

\section{Scale of Points.}

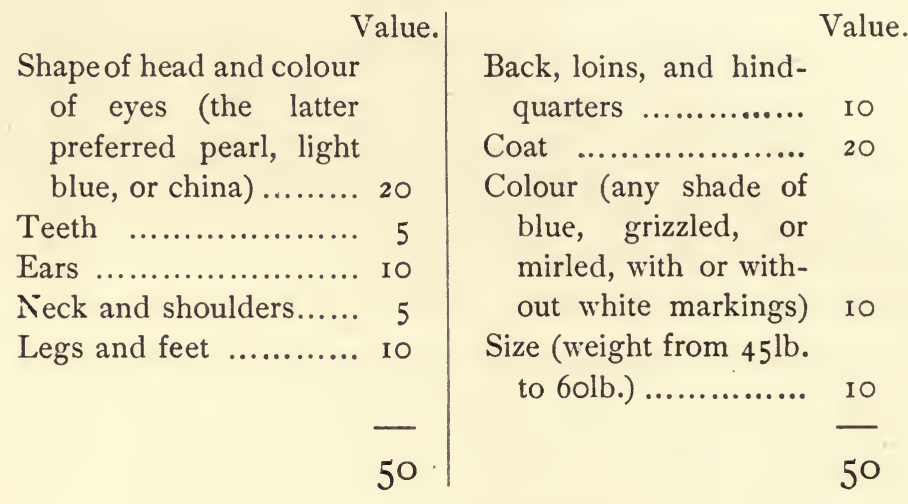

\section{Grand Total 100.}

Disqualifications : soft, curly, poodle-like coat, black and tan and brindled colours.

The special club to promote the interests of the old-fashioned English bob-tailed sheep dog was established in 1888 , and, not to be behind similar institutions, forthwith compiled a list of rules, and submitted the following description of the dog as he ought to be, with the scale of points by which he is to be judged. How far they coincide with what Dr. Ker has contributed, and what I have written, will, no doubt, be observed by those who trouble themselves to peruse this chapter. 
The description and points of the "Old English Sheep Dog," as adopted by the club, of which Dr. Edwardes-Ker, Woodbridge, Suffolk, is the secretary, are as follows :

Skull.-Capacious and rather squarely formed, giving plenty of room for brain power. The parts over the eyes should be well arched, and the whole well covered with hair as defined in "coat."

Faw.- Should be fairly long and square. The "stop" should be defined, but not to a great extent.

Eyes.-These, of course, vary in different colours of dogs. In the dark blue shades they should be dark brown. In the lighter colours they will be found to follow them, and become paler in shade, while where white predominates, a wall or marble eye may be considered very typical.

Nose.-Always black in colour, fairly large and capacious.

Teeth.-Strong and firm, and should be evenly placed in the jaw. Working dogs often have their incisors broken off. This is in no way detrimental.

Ears.-Medium sized and carried close to the head, coated with hair of a moderate length.

Legs.-The fore-legs should be straight and 
possess plenty of bone. They should remove the body a medium height off the ground, without approaching legginess. They should be well-coated all round.

Feet. - Moderately large; round; toes well arched and pads capacious and hard.

Tail.-This is a most important point in the Old English sheep dog. Without a doubt many dogs are bred without the slightest approach to a caudal appendage, while, on the other hand, some in the litters will be found with half, three-quarters, and whole length tails. The breeding of those without tails should be encouraged and persevered with, and be given preference to in judging, providing the dogs are good elsewhere. A tail of any length takes away the appearance and the corkiness of the dog. A docked dog can generally be detected by the bluntness at the end of stump.

Neck and Shoulders. - The neck should be fairly long, arched and graceful, and well coated with hair. The shoulders should be set on slopingly, and the dog generally be found to stand lower at the shoulders than on his hind quarters.

Body.-Rather short and very compact. The ribs should be well sprung, and brisket deep and capacious. The loin should be very stout, and 
to a certain extent arched, while the hind quarters should be bulky, and the hams densely covered with coat, "very often of a softer and more woolly description than is to be found on other parts of the body.

Coat.-Profuse and of good texture, i.e., fairly hard and strong. There should also be a double or under coat.

Colour.-Varies, but preference should be given to dark blue, light or pigeon blue, and steel grey dogs. The colours are generally intermixed with white, which imparts to the dog a more attractive appearance. White collars, legs, chest, and face should be encouraged.

Height.-Fair stand and measurement of the shoulder from 20 inches upwards. The bitches, of course, smaller than the dogs. Great height is not to be encouraged, for it takes away the corkiness and cobbiness of the dog.

General Appearance.- $-\mathrm{He}$ is a strong, compactlooking dog, profusely coated all over. He generally gallops with his head down, having a peculiar springing style of movement, and his whole make and shape of body should strike one as being very much after the style of a bear, an animal which people, not conversant with the breed, will generally quote as an analogy. 
Scale of Points.

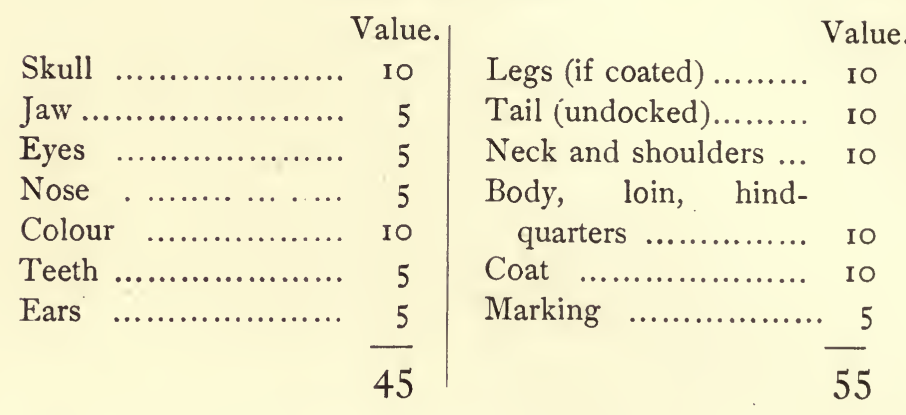

\section{Grand Total 100.}

The above description has not been received with any great degree of favour in some quarters, still I consider it, together with the scale of points, worth printing here. At any rate, they give some amount of completeness to what has been written on the subject. Without going into any minute criticisms of the matter the club has put together, I may take exception to what is said about the feet being moderately large, and also their particulars as to the tail. Personally I believe a skilful operator can reduce the stern of a puppy in such a manner as to make it an absolute impossibility for even an expert to tell whether this shortening be natural or otherwise, and we must not forget that natural "bob-tails" are less common than the artificial production. 



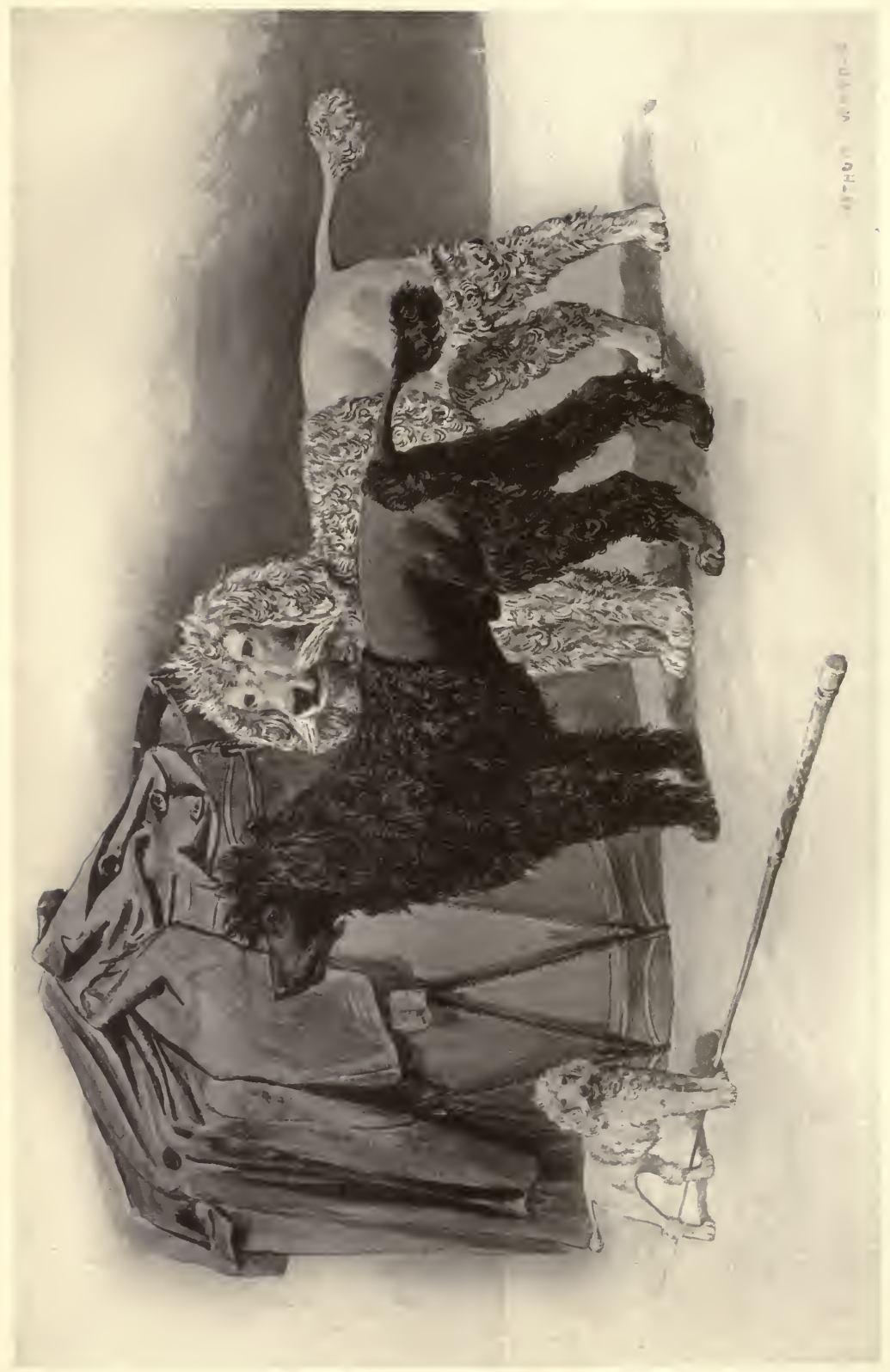




\section{CHAPTER VII.}

\section{THE POODLE.}

THERE used to be an impression abroad that there were two varieties of poodle, the Russian poodle and the French poodle; but the error, however it arose, is now corrected, and we know that the black and the white poodle are common to both nations, as they are to other countries in Europe. A huge black or brown dog occasionally seen in England, where it went by the name of the Russian retriever, was originally imported to cross with our own retrievers to increase the size of the latter. At any rate this was said at the time, but our retrievers were already quite big enough, and the so-called Russian dog was nothing more than a huge poodle.

As a fact, there are more than two varieties of the poodle, and I cannot bring myself to believe that this great big dog from Russia, 8olb. weight or more, is of the same variety as the little mite of a creature 6lb. in weight, or even less, which is well known and can be trained to perform sundry 
tricks, which it does pretty nearly as well as the bigger dogs. Indeed, that of standing on its head on the palm of its owner's hand could not be well done by a dog thirty or forty pounds in weight. Poodles of the last-named sizes are the most common, and they may be classed as the ordinary variety. Such are found coal black in colour, snow white-is there not a rhyme beginning? "A poodle, white as winter's snow"-chocolate or brown, brown and white, and black and white.

Then there are the ordinary curly-coated poodles, which it is customary to shave, and clip, and trim; and the extraordinary coated poodle, whose coat hangs down in cords of extreme length, that in a good specimen actually trail upon the ground. $\mathrm{He}$ is known as "the corded poodle," the other as the curly-coated poodle, and the latter is the more numerous and more popular animal of the two. The corded poodle is by many owners likewise subjected to the scissors and the razor. I never saw a brindled poodle or a fallow-coloured one with a black mark, and that such do not exist proves, I think, that the poodle is a very distinct variety of $\mathrm{dog}$, and one that at no time has been crossed with either the bulldog or mastiff, animals, which appear to have always perpetuated their colour in a greater or smaller degree. 
The poodle is certainly a dog of foreign extraction, but when he was first imported to this country from France or from Germany there is no record. But his sagacity, docility, amiability, and all the other complimentary "tys" applicable to a dog, and which had made him a great favourite on the continent, acted in a similar manner here, the poodle soon made a domicile amongst us, and as it were became one of ourselves. In France he had been used, and is still used in some localities, as a sporting dog, in much the same manner as we utilise a spaniel or a retriever; but with us he has always come under the non-sporting section, hence his appearance in this volume.

It has been said that the larger variety of the poodle (not the Russian monster) had been found useful in crossing with our water spaniels, especially the Irish variety. Whether this was so or not it is difficult to determine, but we have the fact that in the "Sportsman's Cabinet" ( 1803 ) there is an illustration of the "Water Dog" as totally distinct from the water spaniel, and which is neither more nor less than an ordinary curly-coated poodle, a black or brown with a white muzzle and four white feet; his coat is untrimmed, but the tail is cut. The letterpress tallies very much with Reinagle's excellent engraving, and there are 
elaborate instructions how to train the "water dog" (poodle) for sporting purposes. Youatt ( 1845 ) gives us another excellent drawing of a poodle-a white dog with dark ears and a few patches on his body, and not at all unlike that in the "Sportsman's Cabinet."

Jardine, in his "Naturalist's Library," alludes to the "Water dog or poodle," which, he says, was of German origin, "and in its most perfect state is not of British race. It rose into favour first in Germany, and during the revolutionary wars was carried by the troops into France, and only in the latter campaign became familiar to the British in Spain and the Netherlands." This is probably the case, but we fancy at no time in its history in this country was it used in connection with the gun to the same extent as it was on the continent.

A recent writer in Le Chenil says the poodle is undoubtedly a dog of very old family-one of our oldest races of dogs. As early as 30 A.D., the poodle was sculptured on bas-reliefs, partially clipped on his coat as he is to be found now; Conrad Gesner wrote of him in I555; he was put on canvas by the leading animal painters in the sixteenth century. In Martin de Vos's familiar picture, "Tobit and his Dog," there is no mistaking the shaved or clipped poodle, whilst even earlier than 
this, about I 490, Bernardino Pinturicchio painted his series of pictures, "Patient Griselda," in which a little poodle, prettily trimmed, is not the least interesting portion of the canvas.

"Stonehenge," in his "Dogs of the British Isles," gives a very interesting account of the poodle, the writer of which, I fancy, was Mr. Lewis Clement, who had considerable experience of the breed, especially as a sporting dog on the continent. He would divide the poodle into two grand classes, one including the dog used for sporting purposes, the other including performing, companion, and toy poodles, and each of these two classes comprises several different types. The writer then goes on to quote from "Der Hund und Seine Racen," by Dr. Fitzinger, who says there are six very distinct varieties of poodles, viz: der gross Pudel, der mittlere Pudel, der kleine Pudel, der kleine Pintsch, der schnür Pudel, and der Schaf-Pudel, besides other' and many varieties produced by crossing.

The author proceeds to describe these half-dozen varieties, the first of which, the great poodle, he says, originated probably in Morocco or Algeria.

$\mathrm{He}$ is always larger than the largest sized spaniel, which, however, he resembles in form. $\mathrm{He}$ is robust in build, and has a peculiarly thick and full covering of hair. His os occipitis is 
well pronounced, his head is round, his forehead is strongly arched, his muzzle is short, high, and stumpy, his neck short and thick; his body is compact and cobby, his legs are comparatively short and strong, and he is more web-footed than any other breed. The hair over his body is long, thick, soft, woolly, and entirely curled, even over the face, and especially the mouth, where it forms a decided moustache. On the ears and tail the hair is more knotty and matted. Specimens of this breed are white, light liver, liver, light grey, dark grey, dark liver, or black. Sometimes the markings are peculiar, inasmuch that, on a light ground, great irregular dark grey, or black patches occur. When the dogs are liver-coloured or black, there are white spots on their muzzles and throats, on the nape of their necks, on their breasts, bellies, feet, and tail. They are seldom cropped, but are almost invariably docked. The Italians call them can barbone; the French barbets, grands barbets, barbetons caniches; the English denominate them water dogs, water spaniels, finders, and poodles. Neither the Greeks nor the Romans appear to have known these dogs, and the old German authors of the middle ages do not mention them. In the sixteenth century they are, for the first time, mentioned by Conrad Gesner, who, in 1555 , gives a description and illustration of these dogs. The great poodle is most easily trained, and his peculiar adaptation for marsh work is not found in any such high degree in any other kind of dog.

His liveliness, attachment, and faithfulness, combined with his good temper, trust, and obedience, make of him a thoroughly good companion. He always looks for his master, likes to please him, and is never tired of doing all he can to further that end. $\mathrm{He}$ is a splendid swimmer, and the best of water retrievers. He grasps everything he is taught so readily that he is trained very quickly; hence he is a good performer in whatever pursuit his talents may be called into requisition.

Der mittlere Pudel, or medium-sized poodle, is only a variety of the great poodle. He has the same qualities and properties. Size is the only difference between them; he is sometimes twothirds, and sometimes only half, the size of his greater congener. 
There is no difference in their colour or markings, and the mittlere Pudel is also docked.

In Italy, France, or England no difference is made between this variety and the great poodle; they go by the same name. This medium-sized poodle, however, was known to the Romans, although no writing mentions it; but on certain pictures on antiques, from the time of the Emperor Augustus (last century before Christ), his portrait is found. He was not, however, known to the Germans of the middle ages. In many places he is used for finding truffles.

Der kleine Pudel, or little poodle. In this mongrel race the peculiarities of their ancestors are so pronounced that they are called "half bastards of pure crossing" (sic). They look like the medium-sized poodles, but are only half their size, and in make they are much lighter. Their heads are not so high, the muzzle is longer, the body slenderer, and the legs are comparatively thinner. The hair covering the body is long, fine, and soft; on body and legs more curled and more woolly; on head, ears, and tail it is decidedly longer and more knotty, but silky. The tail is carried straight, and sometimes its tip turns slightly upwards. On the face the hair is long, especially about the mouth. The colour is the same as for the previous classes.

The Italians call the kleine Pudel barbino, the French petit barbet, and the English little barbet (?).

Portraits of these dogs are also seen on antique monuments, but they are not mentioned in any German MSS. of the middle ages.

The little poodle is not pure, but a mongrel. He has, however, all the winsome qualities of the larger breeds. $\mathrm{He}$ is used as a lapdog by ladies, and can also be employed for finding truffles.

Der kleine Pintsch, or the little griffon (Aquaticus gryphus). The peculiarities of this mixed race lead to the supposition that it is a product of a cross between the little poodle and the Pomeranian (?). It has a long head, an arched forehead, a stumpy mouth, and very long hair on its body. In all other respects, and in colour, it is like other poodles. They are called barbet griffons and chiens Anglais by the French. 
Der schnür Pudel (corded hair poodle) is of pure breed, but seems to be some variation of the large poodle, from which, however, he differs in his coat. His size is quite that of the large poodle, the length of his body being sometimes $3 \mathrm{ft}$. (German), and in build, in all cases, he is very much like the large poodle. The characteristic feature of this breed is the peculiar nature of its coat, which is not only of great length, but which grows in a peculiar manner-i.e., the soft woolly hair does not hang down in ringlets or in curls, or in feather, but it comes down regularly in rows of straight cords, from the skull, from the middle line of the neck, and of the back; and it hangs down on both sides of the head, neck, and body, sometimes $2 \mathrm{ft}$. long, dragging on the ground, so that the legs are invisible. From the ears and tail the hair sometimes hangs to the length of $\mathrm{I} \frac{1}{2} \mathrm{ft}$. Only the face, muzzle, and paws are clothed in shorter hair. Generally these dogs are white; rarely are black ones to be seen.

The origin of this dog has been a matter of discussion among savants, some saying that he came from Spain or Portugal, and others from Greece. His qualities are like those of the great poodle, but he is much more valued, simply because he is very rarely met with.

Der Schaf-Pudel, or woolly-coated poodle. His similarity to the great poodle and the Calabrian (?) dog, induces Dr. Fitzinger to think that it is a double bastard, as it is a perfect link between these two breeds. He has the hair of the first; but his size and general appearance are like those of the second. $\mathrm{He}$ has a less arched forehead, and shorter and smaller ears, than the great poodle; his body is more tucked up, he is higher on legs, and his hair more thinly curled on the neck and belly; it is longest on the ears and shortest in front of the legs. On other parts of his body and face his coat is very woolly. His colour is generally white, and then sometimes he has a circle of bluish grey round the eyes, and the top of his nose is of a greyish or fleshy colour. Other specimens are light liver or grey, ticked or spotted, sometimes with patches of brown or black. The breed is generally found in the Campana of Rome. 
The writer of the article alludes to the skill with which the poodle, when used in France for duck shooting, collects the wounded game at night-time, in which work he shows skill and intelligence simply unsurpassable, in short, he is so well adapted for that sort of work that in French his generic name caniche, is decidedly derived from duck (canard). $\mathrm{He}$ is also called chien canne, which is quite as much a derivation; and in some districts where the ooze abounds the name barbet is applied to him, this word being a diminutive for barboteur, i.e., a mud-lark, a dog fond of paddling about in the mud. Some writers have, on the contrary, held the barbet to be a diminutive poodle, the toy of the variety in fact, but we must accept Mr. Clement's opinion, supported as it is by "Stonehenge," as most likely to be correct. It seems rather odd that these working poodles, which have to endure the cold water in winter, and the mud and the slush, for the most part have their jackets cut, the curls being taken closely off from the middle of the back to the hocks, and the remainder of the coat is more or less trimmed. Some of the continental fowlers likewise clip him on the face, leaving the moustache and an "imperiale," a quaint and odd idea, which in no way can add to the utility of the 
dog, whatever it may do so far as appearance is concerned.

Much more could be written about the poodle as a sporting dog, but as one of the Modern Dogs of Great Britain he is used only as a pet and companion, purely a fancy dog and as a performer on the stage, in the circus, or in the streets. $\mathrm{He}$ is a "show dog" in the proper acceptation of the term, and although there are other varieties of the canine race taught to perform tricks of various kinds, the poodle is accepted as the performing dog par excellence. It is he who stands on his head, climbs ladders, walks on rolling barrels, turns somersaults both backwards and forwards, feigns death, and performs a host of other accomplishments of which terriers are his imitators. Writers on dogs have always had anecdotes to tell of the sagacious poodle.

Even Colonel Hutchinson, in his excellent work on "Dog Breaking," cannot pass over the performances in Paris of a celebrated poodle named Domini, who not only made up any number that might be desired by selecting corresponding cards upon which numbers had been written, but told the time by the clock, played a good game at dominoes, and otherwise so astonished the gallant Colonel that he gives two or three pages and 
an illustration to this well-trained animal. This had happened something like fifty years ago, but long before that time dogs had been trained to perform certain parts in the circus or elsewhere. In the Bodleian Library there is a manuscript of the fourteenth century, upon which is drawn a performing dog, i.e., one sitting upon its haunches, and Strutt tells us that none of these early illustrations represent the $\mathrm{dog}$ in any other position than the above, when he is supposed to be in the throes of his performance. The Bodleian dog is, however, not a poodle; it might be a beagle or it might be a terrier, probably it represents the mongrel of that period. "Dogges that dance the morrice" appeared at Bartholomew Fair towards the end of the sixteenth century.

Early in I 700, there was a showman, Crawley by name, who performed in London and out of it, with a troup of poodles highly to the satisfaction of the curious at that time. "The Ball of Little Dogs" he called his exhibition; the dogs he said came from Louvain (even then we had a taste for something foreign), and had performed before Queen Anne, greatly to Her Majesty's delight. These dogs danced, two of them, with the grandiloquent titles of Marquis of Gaillerdain and Madame de Poncette, showing extraordinary 
training by the manner in which their movements kept time and cadence with the music which accompanied them.

When Sadlers Wells was a more fashionable place of amusement than is the case now, at the beginning of this century, much interest was taken in some performing poodles, one of which, dressed as a lady, was carried by two other dogs and seated at a table where a banquet was supposed to be spread, of which the "lady dog" and some others partook, their attendant waiters being canines of less aristocratic appearance. This same body of dogs concluded their performance in the part of soldiers, first attacking and then taking a toy fort by storm. This company is said to have consisted of about eighty animals, most of them small poodles, the remainder little spaniels.

However, all these feats are not one tithe better than may be seen at our shows and exhibitions at the present time. I have seen a poodle turn a double somersault, others turn somersaults either backwards or sideways at the will of their trainers; they can still "take a hand" both at cards and dominoes, and their tight-rope walking on the hind legs, or on all-fours with a monkey on their backs, and their steeplechases with monkey riders, are certainly ahead of anything in the way of poodle 
training presented before the public in olden times. Only the other day I saw two little poodles on the stage at Westminster Aquarium that gave an excellent bout at boxing, standing on their hind legs, the gloves being placed on their fore paws, and sparring and striking each other in the face and neck with as much pugnacity as two bipeds might display. As I write, I should say there are now in 1893, at least half-a-dozen troupes of performing dogs in the metropolis, and each contains several poodles.

The writer of "Stonehenge's" article lamented the fact that so few poodles were kept in this country at that time, although they had long been fairly established as a British dog. The Kennel Club Stud Book was first published in 1874 , and the following year poodles were included in its pages, but there were only half-a-dozen entries. Later, the variety became more popular, and now each year's registration contains on an average between thirty and forty poodles. This increase is, no doubt, owing to the establishment of a Poodle Club, which was done in 1886 . It contains a fair number of subscribers, whose object is, like that of other members of specialist clubs, to improve the dog and to encourage his exhibition at shows, where they provide special prizes for him. 
A well-arranged schedule would contain two classes for previous winners of three or more first prizes, i.e., one for blacks, the other for whites, and even these might be sub-divided according to sex. Then there would be separate open classes for black corded dogs and for bitches; the same for white corded dogs and bitches; and four distinct divisions for black or white other than corded. Although some admirers do not set great store by the brown and parti-coloured poodles, two classes should certainly be made for poodles any variety other than black and white. Perhaps in countries where the poodle is more numerous than is the case here, it might be advisable to make the classification according to weight.

Some of my readers may wonder why a dog with all the intelligence and faithfulness of the poodle is not the most popular of his variety. Scientists have told us that his "cerebral cavity is more capacious than in other dogs, that the frontal sinuses are fully developed, and that the general formation of the head and skull exhibit every indication of extraordinary intelligence." But the poodle is, like most dogs with curly coats, a rather strong smelling animal, and not always quite a pleasant companion to have in the house. In other 
respects no animal could be better adapted for the purposes of a companion, for he is sensible, a good follower out of doors, seldom fights or quarrels, moreover he is a perfect specimen of faithfulness. We have had our British mastiff guarding the body of an English gentleman on the field of Agincourt. During the Peninsular War, a French poodle accompanied an officer with his regiment. The battle of Castella was fought, the master fell fatally wounded, the dog remained by the body. The cross of the Legion of Honour glittering and sparkling on the breast of the fallen officer attracted the eyes of his enemies. As they stooped down to cut the treasure from its ribbons, the poodle flew at the thieves, and did not cease his attack until, pierced by cruel bayonets, he fell dead alongside his dead master. Anecdotes of the constancy of the poodle could be quoted to almost any extent, and those of my readers who would have some of them I must refer to works that deal more with "dog stories" than can be done in these pages.

As already stated, it has for many years been the custom to shave and clip the coats of some poodles, but whether this was originally done to, in a degree, destroy the strong smell their curly coats, when neglected, possessed, or merely for 
fancy purposes to make them resemble something Nature never made, we cannot tell. Some of the corded poodles are not subjected to this tonsorial process, or they would be shorn of a great portion of their excellence. The length of these cords is, perhaps, the chief object to be aimed at in the production of this variety, and the length such cords have been known to attain is, without exaggeration, phenomenal. The most extraordinary creature in this respect I ever saw was a comparatively small-sized poodle named Fairy Queen, shown by Mrs. Troughear, of Leeds, and for many years it stood almost alone in the variety classes. This was a white dog, and its cords were of such unusual length that they were many inches longer than the height of the animal. When lying at rest, a very close examination had to be made to discern which was the head and which the stern of the curious creature.

Another extraordinary corded poodle was the imported dog, Lyris, successfully shown for many years by Mr. C. Kemp, of Brook Green. This was a large dog, standing $2 \mathrm{I} \frac{1}{2}$ inches high at the shoulder, his head was $9 \frac{1}{2}$ inches in length, his ears measured 37 inches from tip to tip, including the cords on them, and on each side of his body the cords hung down to the length of 23 inches. 



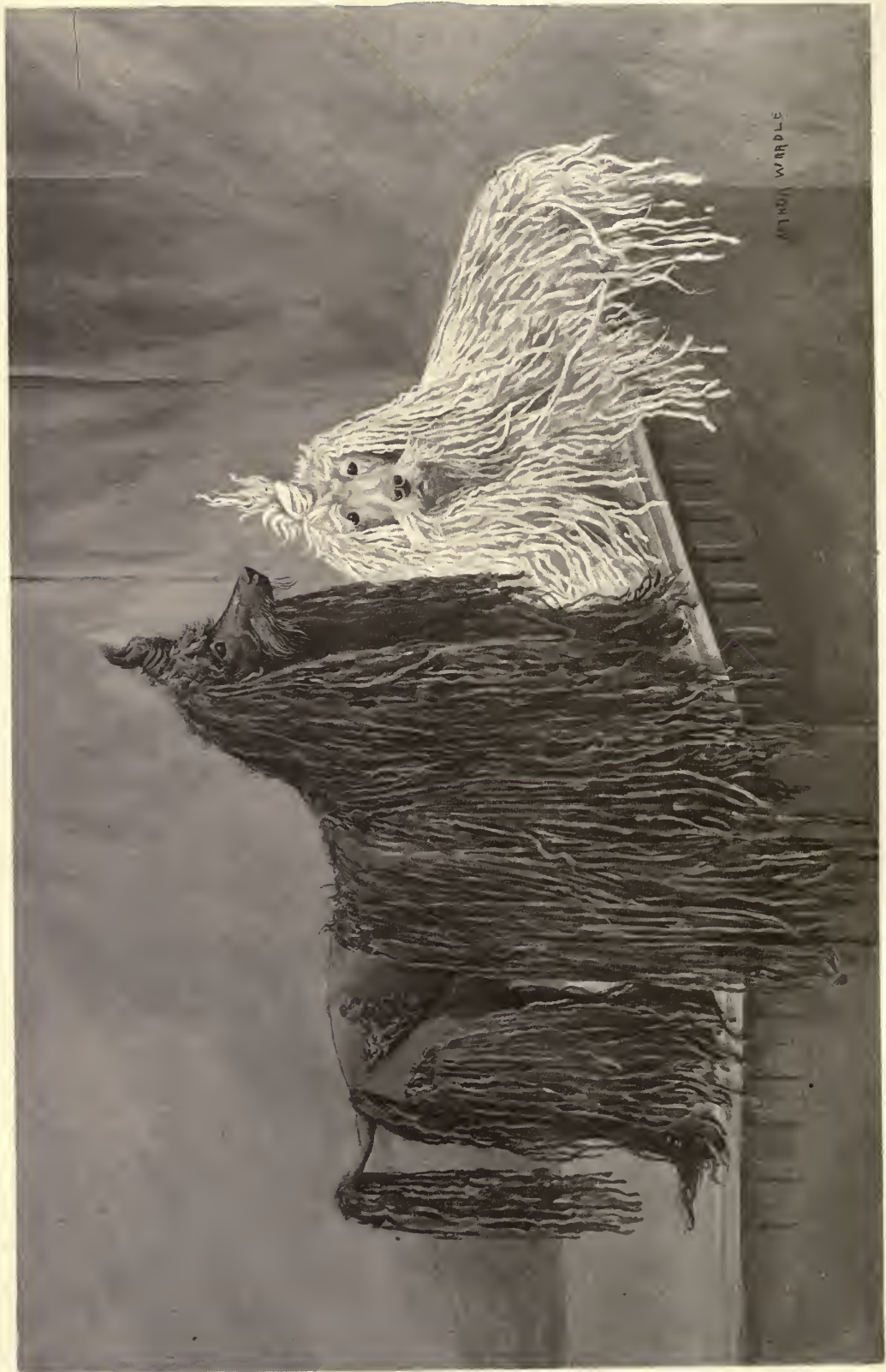


This remarkable dog weighed 64lb., and the measurements were taken after he had won the chief prize in the Kennel Club Show held in Jubilee year, 1887.

When Lyris was mated by Mr. Chance to his bitch Begum, a foundation was laid of a strain which has produced the bulk of the prize winners of late years. The most famous of the initial litter was Mr. Grave's Achilles, perhaps a larger and all round a better dog than his sire, the excellence of the latter notwithstanding. Achilles stands 23 inches high at the shoulders, his head is I I inches in length, many of his cords measuring 30 inches, and falling quite six inches below his feet. It need scarcely be said that Achilles has won pretty much all before him in the show ring.

There are but few exhibitors of poodles at our shows at the present time, and undoubtedly the best kennel of all is that of Mr. R. V. O. Graves, who has an unusually strong team, as a rule almost invincible, including, as it does, specimens both black and white. His Achilles, Witch, Lyribel, The Druidess, and The Ghost, are particularly good of their variety. Mr. H. Sanguinetti, Mr. C. Kemp, Mr. J. Brewer, Mr. J. T. Beaumont, Mr. A. Levey, and Mr. A. Dagois, have had, and still have, good specimens of the breed, and are understood to be 
leading so called fanciers of the poodle. Still, I believe the trouble to keep the coats in good order will always stand in the way of this intelligent variety of the dog being as popular as it might be under different circumstances.

I have already alluded to the fashion that obtains of clipping and shaving the poodle according to the ideas prevailing at the time, indeed, a well regulated and fashionably dressed poodle requires about as much attention to be kept in order as do the jackets of some of our choice little Yorkshire terriers. It is said that the custom of trimming the poodle arose through an anxiety to look after the comfort of the dog, because the long ringlets or cords interfered with the general health of the poor beast that nature caused to wear them. In winter they became matted with snow and dirt; in summer they were uncomfortable and harboured vermin; so it came about that the poodle had to be clipped, and trimmed, and dressed.

All this is done in various fashions, and there are "professors of the art," high in their line, who will dress your poodle for you, and tie him up with ribbons blue or yellow or white, for any charge varying from half-a-guinea to a couple of pounds.

A poodle ought to have his coat attended to even before he leaves his puppyhood. When four 
or five months old it is well for his comfort and appearance, say his admirers, or rather I should say for their fancy, to trim or clip the coat on the face and feet and on the hind-quarters from below the tail and about his buttocks. When he is eleven or twelve months old he should be properly clipped, but, as a matter of fact, it is best to have him clipped three or four times before he is actually what may be called finished, i.e., shaved. This ought not to be forgotten, as were the dog shaved before the skin had become in a degree hardened by exposure to the air, pain would be caused the dog, and perhaps some inflammation might arise, as the contact of the razor is by no means pleasant to the patient. When once matured, and having undergone the preliminary process, a poodle ought, if the desire be to have him neat and in nice condition, to be trimmed some six times in the year-about every two months.

Poodles are, notwithstanding their " clipping," apt to get dirty, the white specimens especially so. Still it does not do to wash them too often, as the water and soap are not likely to improve the coat, and there is considerable difficulty in drying the jacket. Once a month is frequent enough, even not so often as this, unless in the judgment of the owner the dog actually requires it. As a 
matter of fact, the well-known Lyris, alluded to earlier on, was repeatedly exhibited with success, and he looked well, too, without being washed immediately prior to the exhibition. He might be washed, say, and benched in January, and at another show held six weeks afterwards, he would again appear and look equally well without having had an additional tub in the meantime.

Whilst the coats, especially of the corded varieties require so much attention as to clipping, it is only natural that equal care is required to keep that part in order which does not come under the operation of the shears and razor. There is the "bedding" to be considered, for it will never do for one of these extraordinarily long-coated dogs to be on a bench covered with straw or shavings. The best bed is to fill a sack with clean straw or dry pitch-pine shavings, and sew up the ends; then this ought to be properly beaten, shaken, and aired daily, so that no dust remains thereon. The straw or shavings strewn loosely upon the bench in the ordinary fashion are too heating, and, besides, little pieces get into the coat and cause endless trouble to remove. Moreover, dirt of any kind quickly makes the coat matted, the ringlets sticking together near the skin, ultimately causing long tags, which drop off and leave bare 
places. As a matter of fact, too much attention and care cannot be given the poodle in the respect of tending and keeping his coat free from dirt, but he must not be combed or brushed, and the fingers must be used to separate the ringlets. Do not be afraid of soap and elbow grease, but beware of the first appearance of mange or skin disease. The latter is simply ruin to a poodle, at any rate for a time. Here, as in most other matters, prevention is far easier than cure.

When the ringlets, where they are allowed to remain, grow to such an inordinate length as to be in the way of the dog, either so far as exercise or sight is concerned, they ought to be nicely tied up all round. Then the coat of the black poodle has to be dressed with some emollient, and nothing is better for this purpose than a mixture composed of a quarter of a pound of vaseline to half a pint of paraffin. This should be put into a suitable receptacle, which is to be placed in a heated oven and kept there until the concoction is thoroughly blended. It may be scented with any perfume fancy suggests, and must then be placed in a jar, kept covered, and applied when cold.

This dressing, which will darken and brighten the coat of a black dog, is also suitable for brown poodles, as too much washing of the latter, trans- 
forms the dark chocolate shade into a somewhat mealy tint. Should the paraffin odour remain in the dog, an hour in the open air will soon remove any unpleasantness. The dressing should be applied about three times a week.

White poodles require equal care in washing, and a great authority on the breed tells me there is nothing that keeps the coat whiter, and in better order, than Hudson's extract of soap, applied in the usual manner.

In cases where neglect has caused the coat to become matted, it is best to cut off the unpleasant tags close to the skin. Particular attention, too, must be paid to cleaning the coat about and below the root of the tail. It should be frequently washed thereabouts-whenever it seems to be required.

If these instructions are attended to and the poodle be given a little cooling medicine, such as Epsom salts or magnesia, in his food occasionally, he will not be found to harbour anything offensive about him, nor will the smell from his skin or coat be more objectionable than it is in an ordinary long-coated terrier or collie dog. Indeed, one admirer and connoisseur of the variety will have me believe that his favourite dog has not naturally any offensive smell whatever, and that where such is perceived, it arises solely through neglect. 
Thus carefully have I entered into the management and keeping of the poodle as a house dog, because it is only used as such in this country, and because it is the dog above all others that, through neglect to its cleanliness, will become an eyesore, and offensive to its owner, when a little trouble will make it as pretty and as pleasant a dog as man or woman need desire. As to its intelligence and faithfulness, nothing further need be said by me.

Perhaps it may be fresh information to some who have kept poodles to know that this "wool" or "cords" can be used for manufacturing purposes, and although "poodle's wool" is not a mercantile commodity, the owner of a poodle can clip him, have the results made into yarn, and in due course converted into socks or similar articles of wear. One gentleman sent a sample of "poodle's wool" into Scotland, and forwarded me a specimen of the yarn spun from it. The dog from which it was taken yielded four pounds weight of wool, and many of the locks were eight inches in length and over, but the clipping was merely done in the first instance because the coat was falling off. As an old shepherd said when he was told of this, "Aye, aye, nea wonder sheep is sae cheap when these new-fangled dogs can grow four pound o' wool apiece." 
The sample of the yarn I saw was of a silky though rather hard texture, and the manufacturer called it "a very pretty wool;" the spinner said it was difficult to "teaze" because so badly matted, but he thought it likely to card and spin well. When made, the yarn is knitted into socks; the latter seem rather hard, and their wearer tells me, though they are "somewhat harsh and whiskery, they are calculated to create a healthy friction, and are well suited for a cold climate."

One variety of poodle, or at any rate a cross bred poodle, is known as "the truffle dog," although all truffle dogs are not poodles. "Stonehenge," in his "Dogs of the British Isles," gives an illustration of a "truffle dog," which appears to be a cross between a small curly-coated poodle and a terrier. These animals are trained for the purpose of finding truffles, an edible fungus that grows underground in some parts of this country. It is, however, commoner on the continent, in France, Italy, and elsewhere, where pigs are trained for the purpose of finding the dainty article. As a fact, almost all the truffles used in Great Britain are procured from the continent, though they are found in some localities of the south of England in considerable numbers, in Hampshire, Wiltshire, Dorsetshire, Oxfordshire (Windsor Forest was once 
a notable place), and Kent, but no doubt it is produced in other situations where the land is of a chalky nature and where beech trees flourish. This peculiar fungus is said to be a connecting link between the animal and the vegetable kingdoms, as like the former it absorbs oxygen and throws off carbonic gas. Otherwise it is a vegetable pure and simple, but it is of most value for high-class cooking purposes.

As an industry, the occupation of the trufflehunter is rapidly dying out. In Hampshire and elsewhere there are no young men springing up who seem inclined to follow in the steps of the old ones who have made a moderate living by gathering truffles for many years. This is especially notable in the Wiltshire villages, where a quarter of a century and more ago, families were supported by their heads who took trouble to train and keep their favourite strains of $\operatorname{dog}$ for the purpose. One of the chief truffle "hunters" at the time 'I" write is Isaac Bray, of Winterslow, and he, now an old man, has followed the occupation for years. His dogs are well known, and there is always a demand for the puppies, which, before they are trained, are worth $£^{2}$ or $£ 3$ each. Of course a properly trained $\mathrm{dog}$ is worth much more than that, and the owner of a really good one is 
naturally loth to part with his animal, as the livelihood of the family depends so much thereon.

Local traditions say that a Spaniard who settled somewhere in Wiltshire, about 250 years ago, first introduced the truffle-hunting dog, and since that time the industry, if it can be so called, has been carried on. The dogs are very much inbred, thus difficult to rear. They are of any colour, white, even black, and any intermingling of the two. The lighter coloured and white dogs are best for the purpose, as they are easier seen in the coverts and undergrowth. In some instances a black dog has a broad white collar or front placed around his neck, so that he may be better seen by his worker. The training of the dog should commence when he is about four months old, when he is taught to bring to his master a truffle which is thrown for him. This quickly done, his next task is to fetch one of them which is hidden, and following this a truffle is first covered with earth, and this, too, he is encouraged to find and take to his master. So gradually the lessons continue, until the puppy will be quite reliable in finding and bringing in fungi which have been buried by his master two inches or so underground, the dog being, of course, rewarded with some little dainty each time he does his duty well. So far perfect, 
he is now taken out to some place where truffles are known to be, and the dog will find them, thus his training is accomplished with less trouble than either a pointer or setter is broken to find and stand game.

Of course the little dog hunts keenly, and with his nose to the ground, his tail action and quickness on scent are quite equal to what are seen in a spaniel on the line of fur or feather. When a truffle has been "set" or found two or three inches below the ground's surface, the dog will scratch the soil away with his paws in the fashion common to canines, but the better plan, and the one usually followed, is for the owner to dig up the prize, and so prevent any risk of its being injured by the dog's teeth. I need scarcely state that a truffle dog must be thoroughly and entirely broken from his natural inclination to hunt game and vermin.

The truffle is in season in England from November until March, but it can be purchased in most shops where such things are sold, all the year round. As we have said, the occupation of truffle-hunting is little followed now in Great Britain, still I believe that it is one for which there is ample scope, and likely to prove remunerative to the labourer or working man who would commence such work. But he must have no poaching proclivities, else the love of the rabbits or hares amongst which he hunts, 
will induce him to leave his adopted "profession" for another that is against the law of the land.

So far for the poodle, and how useful a dog he is and may be made, I think sufficient has been written to prove, and perhaps the following description of the animal (with the aid of Mr. Wardle's illustrations), published by the Poodle Club, will enable any who do not know what such a dog is like to recognise a poodle when they see him in the streets or on the stage.

A "Poodle Club" was established in 1886 , and the following is the description issued by that body. The numerical points are, however, my own.

\section{"The Black Poodle.}

" General Appearance.-That of a strong, active, and very intelligent dog, cobby in build, and perfectly coated with curls or long ropey ' cords.'

"Head.-Long, the skull large and with plenty of room for brain power, wide between the ears and a slight peak, the parts over the eyes well arched, the whole thickly covered with curls or ' cords.'

"Muzzle.-Long (but not 'snipey'), strong, square, and deep ; the 'stop' should be defined, but not to a very great extent; the teeth should be perfectly level, strong, and white.

"Eyes.-Small, dark, and bright, with a very intel- 
ligent expression; they should be set at right angles with the line of the face.

"Nose.-Large, and perfectly black in colour, with wide open nostrils.

"Ears.-Very long, close to the cheek, low set on, and well covered with long ringlets or 'cords.'

"Neck.-Well proportioned, and very strong to admit of the head being carried high and with dignity. "Chest.-Fairly deep, but not too wide, strong, and well covered with muscles.

"Legs.-Forelegs perfectly straight, very muscular, and 'set on racing lines;' they should be long enough to raise the body well from the ground, but without legginess. Hind legs very muscular, but fairly bent, with the hocks well let down.

"Feet.-Large, strong, and rather wide, but standing well on the toes, and of good shape; the nails perfectly black, and the pads capacious and hard.

"Back.-Short, with body well ribbed up; the loins very strong and muscular, but without fat.

"Tail.-Carried at an angle of 45 degrees, having long ringlets or ' cords,' hanging down.

"Coat.-If corded, thick and strong, and hanging in long, ropey 'cords.' If curly, the curls close and thick, and hair of good quality.

"Weight.-Large, 6olb.; medium, 4olb. ; small, 2olb. and under. 
"The White Poodle and the Red Poodle.

"All the foregoing points hold good for these varieties of the breed, with the following exceptions:

"Eyes.-Yellow or wall eyes (light blue), free from black rims round the eyelids.

"Nose.-Red or liver colour.

"Nails.-Red or pink.

"Back. - The ticks (spots) on back should be red or liver, and the whole body should be free from black ticks.

"Only these three colours (black, white, and red) are admitted, and they should be without mixture.

"N.B.-Clipping or Shaving.-We very strongly recommend that only one-third of the body be clipped or shaved, and that the hair on the forehead be left on."

\begin{tabular}{|c|c|c|c|}
\hline \multirow{2}{*}{\multicolumn{2}{|c|}{ Value. }} & \multicolumn{2}{|c|}{ Value } \\
\hline & 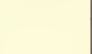 & Stern $\ldots \ldots \ldots \ldots$ & \\
\hline (including expression) & 15 & Coat . & 20 \\
\hline Neck and chest ............. & 10 & Colour $\quad \ldots \ldots \ldots \ldots \ldots \ldots$ & ro \\
\hline Back and loins . & Io & General appearanceand & \\
\hline Legs and feet... & 15 & symmetry $\quad \ldots \ldots \ldots \ldots$ & 15 \\
\hline & & & \\
\hline
\end{tabular}

Grand Total 100. 



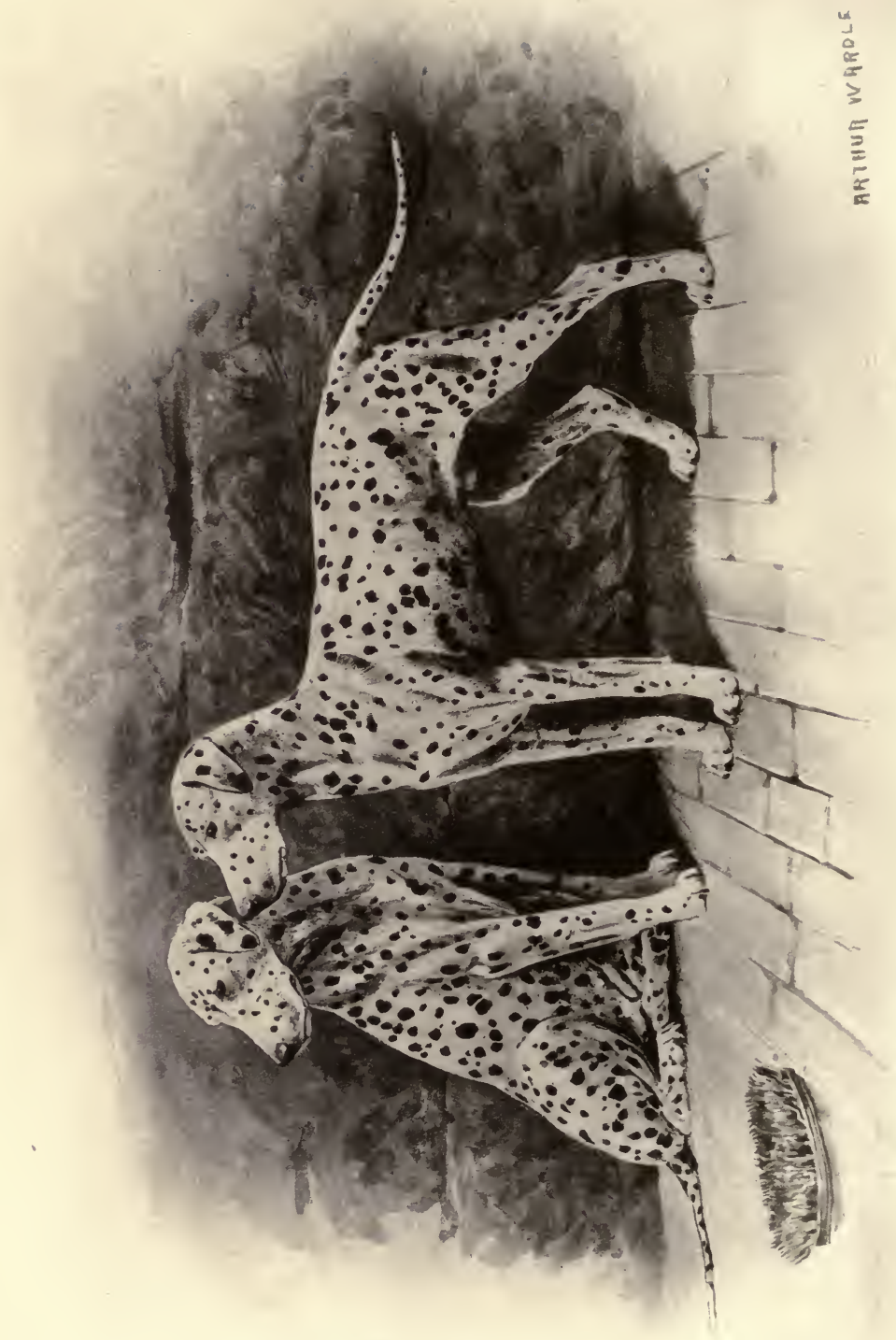




\section{CHAPTER VIII. \\ THE DALMATIAN.}

Some early writers have told us that this dog was used in Denmark to draw carts and other conveyances utilised by the thrifty Dane and his wife to take their commodities from place to place. Perhaps he or an animal something like him was trained for work of this kind, and consequently being a great favourite in that country, he easily obtained the name of "Danish dog," by which he is often alluded to, even by so recent an authority as Youatt.

Again, we are informed that he first came from Spain, and Jardine, in his "Naturalist's Library," mentions a picture of a spotted dog, time the middle of the sixteenth century, from which he believes our modern Dalmatian must have been descended.

Aldrovandus, whom I have had occasion to allude to on several occasions, and who wrote about the same date, gives us a picture of a dog which he 
calls "Canis sagax ad coturnices capiendas pantherinus"- a sagacious spotted dog for taking quails. Now, the dog depicted is spotted over the body with irregularly-shaped marks, and he has one patch on the back; he seems longish on his legs, has his tail shortened considerably, but in shape, character, and appearance of coat, he appears to be more of the setter type than that of the modern Dalmatian. Still, although used for taking quails, the name suggests that he might be the antecedent of the "spotted" dogs of a later date and of modern times: Especially when some writers have told us that the Dalmatian was, at one period of his history, trained for sporting purposes.

Another writer informs "us that this dog came originally from Bengal, when, his peculiar markings made him much admired by the wealthy and luxurious natives, whose establishments were not deemed to be complete without several spotted dogs in the kennels. Moreover, it was at that time (when?) commonly supposed that the dogs had originally been obtained from a cross with a tiger! And such stuff was believed. I am waiting to find that the Chinese had these same dogs many hundreds of years before Great Britain was invaded by the Roman conquerors. 
Leaving a somewhat fabulous statement like the above, and coming to more modern instances, we have our common "coach" dog likened to a bull terrier, and then to a pointer. Richardson says that he has seen one trained to do a pointer's work, and did it as well as the genuine article. This I doubt very much, for no Dalmatian could possess either the range, or pace, or nose, or natural intelligence where game is concerned, as a dog whose parents had been specially trained for a purpose for many generations.

There is little doubt that our modern " coach dog" originally sprang from Dalmatia, a province in the southern part of Austria, hence his name, but from there he might have gone over to Spain, or, perhaps, in the first instance some Spaniard might have sent him out to Dalmatia, where the enterprising inhabitants soon claimed him as their own. However, it does not matter much what country first gave him birth.

The Dalmatian is with us now, and towards the end of last century and up to the middle of the present one, he was usually seen following the carriages of those wealthy enough to keep such an ornament. He was fond of the horses, lived in the stables with them, was little or no trouble to the grooms, and the portly coachman did not think 
his master's equipage perfect unless it had a nicely spotted dog running under the carriage at the horses' heels. The Dalmatian differs thus much from other dogs that his attachment was to the carriage and horses, other dogs make friends with the human race.

Perhaps it was for this reason the coach dog obtained a reputation for stupidity which it did not deserve. It showed uncommon skill and sagacity in keeping close to the carriage in the busiest and most crowded thoroughfares, was seldom or never lost, and "Idstone" tells us of a celebrated performing dog of this variety which acted as clown, and the best of the kind he had ever seen.

The Dalmatian still often appears and assists to earn his master's living by performing on the stage ; many good ones of the kind I have seen, but he is too staid and sober to be a perfect " clown" dog, and go through such funny antics as that brown and white cross-bred creature "Professor" Wingfield has had so long as the leading member of his excellent troupe of performing canines.

When taken out of the stable into the house, our Dalmatian makes quite as good a companion as any other dog; he is kindly in disposition, by no means quarrelsome-indeed I cannot call to recollection the time when I saw one "have a turn" 
with a snarling neighbour-cleanly in his habits, and thoroughly tractable. Once it was the custom to cut his ears off, happily this piece of barbarity has long since been discontinued. Bewick, the eminent wood engraver, gives us a Dalmatian so mutilated, but in Reinagle's drawing in the "Sportsman's Cabinet" it is difficult to tell, owing to the position of the dog-he is galloping-whether the ears are on or off. I fancy they are off.

The latter illustration is a most typical one in the shape and form of the dog, but his spots might be more distinct on the body; on the stern his markings are about perfect, and far ahead of anything I know of at the present day. Reinagle's $\operatorname{dog}$ is, however, darkly marked on the body, and when this is the case, he is likely to be so on the stern likewise, the difficulty being to obtain a perfectly marked dog with a proportionate number of spots on his caudal appendage.

As to the modern Dalmatian, he is sometimes marked with brown or liver spots on the white ground, and these markings, when clearly defined, are quite as good as the pure black ones on a white ground. Again, he is frequently seen with what is called "china " or "wall eyes," a peculiarity frequently appearing in all varieties of the dog that have much white about them, and where the 
white is mixed with black, or what is often called "blue." Personally, I do not consider the "walleyes" detract from the animal's appearance.

In the club standard such is not alluded to, and I do not believe any judge who found a perfectly marked Dalmatian with this light-coloured eye would disqualify or even severely handicap him on its account. Mr. T. Newby Wilson, of The Landing, Newby Bridge, Ulverston, has at the present time the best kennel of Dalmatians, his liver spotted Prince IV.; his black spotted Acrobat and Landing Boy being perhaps his choicest specimens. Another excellent liver or brown marked dog is Doncaster Beauty, and amongst the first rank in black and whites his Berolina, Mr. A. E. Paley's Black Prince, and Mr. H. C. Hodson's Goblin must not be forgotten. Mr. Hugo Droesse, of London, the late secretary to the specialist club, has from time to time shown some excellent specimens. Mr. H. Mercer, Newcastle, Staffordshire; Mr. J. H. Foster, Cheadle Hulme, Cheshire; Mrs. H. Carthew, Ulverston; and Mr. R. J. Hartley, Bridgenorth, Salop, have lately owned and still own some very good dogs of the variety, which, however, are more used for show purposes and for the adornment of the benches than to run after their masters' carriages. Mr. James Fawdry, Sutton Coldfield, 
has always been a great admirer of the breed. His dog Captain was one of the best of his day, and at the earlier shows Mr. R. J. Lloyd Price used to win with a dog called Crib, which was quite equal to the best we have now. Another good one came from Kirkby Lonsdale, Dr. James' Spotted Dick, and about twenty-five years ago there were, perhaps, more of these coach dogs in the north of England than in any other part of the country, though in Staffordshire Messrs. Hales had a kennel containing many first-rate specimens.

The Dalmatian has not of late years proved particularly popular with the general public; he has been left to the care of the servants, and children jeered and called him "the plum-pudding dog." $\mathrm{He}$ has not deserved such treatment, and although I do not go so far as many of his admirers and vouch for his excellence as a sporting dog when trained for the purpose, I do believe that brought up as a companion to man, he proves quite equal to any other of the canine race.

Perhaps his lack of popularity (a special club was established in 1890 for the purpose of increasing his fading fortunes) may have been owing to the great difficulty in breeding perfectly marked specimens. Litter after litter may be produced, 
the progeny of the best parents, without a fairly marked puppy in the lot. Some turn out too dark, others too light; one may have heavy black ears, another may, when fully grown, look as if a huge bottle of ink had been emptied over him, and there does not appear to be any rule or guide by which to breed for perfect markings.

In poultry, something towards breeding for markings alone, can be done, as is the case with the black and white Hamburgs, silver spangled and silver pencilled. To get perfectly marked pullets you breed from one strain, to obtain equally good cockerels you breed from another. There does not appear to be any such rule with regard to the spotted dog, and in most cases when a good one is produced it is by a sheer fluke.

Another thing against his popularity is that it is hardly possible to tell when the puppies are born, nor for long after, how they will be marked when fully matured. For instance, they usually come into the world white. Occasionally some are thus early marked with faint spots, or black ears, or both; but this is not as things ought to be in a specimen that is expected to turn out perfect. About the tenth day after birth, the spots commence to make themselves apparent. There is a dark ridge along the belly, the ears blacken, the back becomes 
slightly darker, and about the third or fourth week most of the spots, though ill-defined, are visible on the body. So the markings continue to develop until the puppy is some three months old or so, at which period all the spots on the body should be pretty distinct.

However, the stern or tail generally remains white until about the fourth month, when, if there are to be spots thereon at all, such should begin to appear. Still, very often they are not even faintly visible until the twelfth month, and the quality and appearance of a Dalmatian puppy cannot be told definitely and as a certainty until it is twelve or fifteen months old-never earlier. So those who are in the habit of purchasing puppies at six weeks, when a Dalmatian is the object, must act in accordance with these facts. As a rule a breeder of the variety will not sell his puppies at so early an age. Did he do so, he might, for a couple of pounds or so, dispose of what might in the end turn out to be the best dog he ever bred, worth probably thirty or forty pounds. The latter is, however, an unusual sum to give for an animal of this variety, still one pretty nearly perfect might pay the purchaser at that amount, in stud fees, and prizes he might win. After writing the above, I need.-hardly say that occasions are not isolated 
where an owner of Dalmatian puppies has, on their birth, finding them without marks of any kind, ordered the whole litter to be destroyed.

Although the Dalmatian Club has been energetic, and has done good work since 1890 , when it was first inaugurated, it has not been able to popularise its special dog to any great extent. At our largest shows the club is in the habit of giving special prizes and causing separate classes to be provided for the black and brown spotted varieties, thus enabling the two to compete on their own merits. Still "even this has not been the means of increasing competitors to any great extent. At Cruft's huge show held at the Agricultural Hall in February, I893, although eleven classes were provided and seven special prizes, there were but twenty-three entries, and only thirteen dogs actually competed, several of them being entered in more than one class. Were it not for a few ardent admirers of the variety, I fancy that the " coach dog" might, in a few years, become pretty well extinct so far as this country is concerned.

The following is the description of the Dalmatian adopted by the club. It will be noticed that thirty points are allowed for colour and markings; still, if a dog were pretty well patched black and white, however perfect in other particulars, he 
would be disqualified, for the distinctness of the markings are here a sine qua non :

"The Dalmatian in many particulars much resembles the pointer, more especially in size, build, and outline, though the markings peculiar to this breed are a very important feature and very highly valued.

"In General Appearance the Dalmatian should represent a strong, muscular, and active dog, symmetrical in outline and free from coarseness and lumber, capable of great endurance combined with a fair amount of speed.

"The Head should be of fair length, the skull flat, rather broad between the ears, and moderately well defined at the temples, i.e., exhibiting a moderate amount of stop, and not in one straight line from the nose to the occiput bone as required in a bull-terrier. It should be entirely free from wrinkle.

"The Muzzle should be long and powerful; the lips clean, fitting the jaws moderately close.

"The Eyes should be set moderately well apart, " and of medium size, round, bright and sparkling, with an intelligent expression, their colour greatly depending on the markings of the dog. In the black spotted variety the eyes should be dark (black or dark brown); in the liver spotted variety they should be light (yellow or light brown). 
"The Rim round the Eyes in the black spotted variety should be black, in the liver spotted variety brown-never flesh-coloured in either.

"The Ears should be set on rather high, of moderate size, rather wide at the base and gradually tapering to a rounded point. They should be carried close to the head, be thin and fine in texture, and always spotted, the more profusely the better.

"The Nose in the black spotted variety should always be black, in the liver spotted variety always brown.

"Neck and Shoulders. - The neck should be fairly long, nicely arched, light and tapering, and entirely free from throatiness. The shoulders should be moderately oblique, clean and muscular, denoting speed.

"Body, Back, Chest, and Loins.-The chest should not be too wide, but very deep and capacious, ribs moderately well sprung, never rounded like barrel hoops (which would indicate want of speed), the back powerful, loin strong, muscular, and slightly arched.

"Legs and Feet, of great importance. The forelegs should be perfectly straight, strong, and heavy in bone, elbows close to the body, fore-feet round, compact, with well-arched toes (cat-footed), and 
round, tough elastic pads. In the hind legs the muscles should be clean, though well defined, the hocks well let down.

"Nails, in the black spotted variety, black and white, in the liver spotted variety, brown and white.

"The Tail should not be too long, strong at the insertion and gradually tapering towards the end, free from coarseness. It should not be inserted too low down, but carried with a slight curve upwards, and never curled. It should be spotted, the more profusely the better.

"The Coat should be short, hard, dense and fine, sleek and glossy in appearance, but neither woolly nor silky.

"Colour and Markings.-These are most important points. The ground colour in both varieties should be pure white, very decided, and not intermixed. The colour of the spots in the black spotted varietý should be black, the deeper and richer the black the better; in the liver spotted variety they should be brown. The spots should not intermingle, but be as round and well-defined as possible, the more distinct the better; in size they should be from that of a sixpence to a florin. The spots on head, face, ears, legs, tail, and extremities to be smaller than those on the body.

"Size.-Dogs, 55lb.; bitches, 5olb." 
Standard of Excellence.

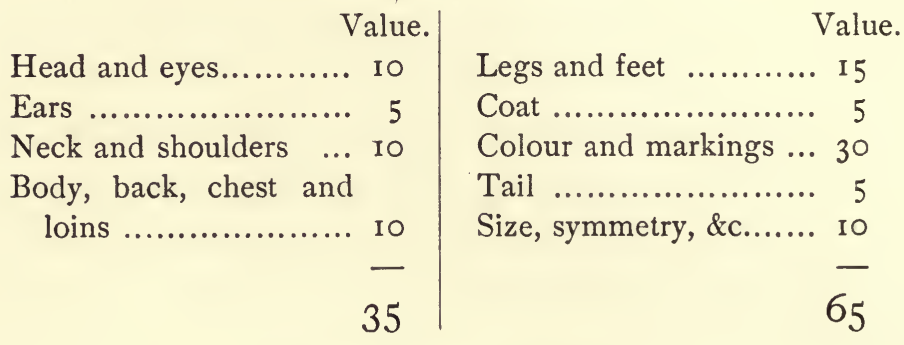

Grand Total, 100. 



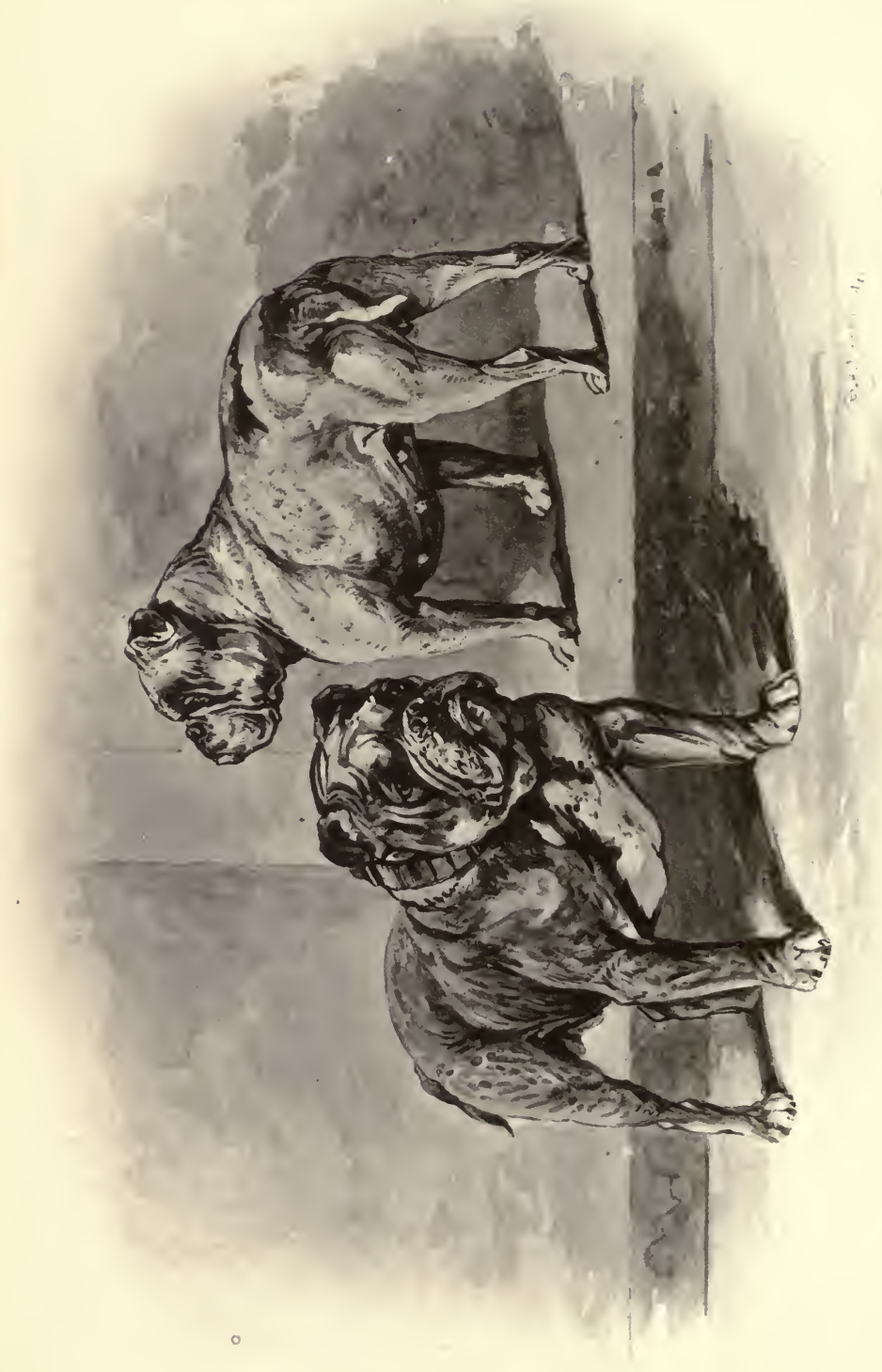




\section{CHAPTER : IX. \\ THE BULLDOG.}

Time is known to play grim jokes with historical monuments, but it probably has never burlesqued anything more than it has our national emblem, the British bulldog.

Evolved for a specific purpose-a purpose long since stamped out both by law and by sentimentthe present day examples can only be looked upon as the result of breeding for certain points not desired or found in any other kind of dog. That the bulldog can claim as great pretensions to antiquity as any other now so-called breeds is not to be denied; but to say that bulldogs are bred to-day on the same lines as they were even sixty years ago would be an assertion that could not by any evidence be defended.

Ancient writers have been quoted ad nauseam, but, interesting as these extracts may be as references to the early history of dogs in general, they bear no coherent testimony that the animals 
they refer to had more than a faint resemblance to the recognised type of bulldogs in 1893 .

Evidence which is far more reliable is at our disposal in the pictures published towards the end of the last and the beginning of this century-the epoch when bull-baiting was in vogue-and, judging from these pictures, the bulldog of that time was but a phantom-like shadow of the animal the fin de siècle bulldog enthusiast has by patience succeeded in breeding.

Thus to him who, nowadays, wishes either to breed or to own an up-to-date specimen, it will be so much useless and embarrassing learning if he hampers himself with any considerations as to the outline and general appearance of what has been handed down to him regarding the animals his ancestors looked up to as bulldogs. Should he decide upon breeding bulldogs he will find, in order to produce a specimen at all approaching the modern ideal, that, instead of wasting time in pondering over the old type, he will have to employ that particular style of dog which may at the moment be in fashion.

He need have no misapprehension that the type in general will in the future change much, if at all; nor need he fear that the goal he is striving for will be advanced. For it must be remembered that the 
standard laid down for this breed has not materially altered during the last twenty years, though judges' decisions may have sometimes been at variance with, if not diametrically opposed to, the standard type. The very fact of there being now two bulldog clubs is a guarantee that no radical change in the standard will ever be permitted, as one or other of the clubs is certain to hover round so safe an anchorage as an established type. If either club sanctions what sensible men must know is a departure from what is correct, it is only reasonable to suppose that in the fulness of time that club will sink in public estimation.

The miasma of the breed is that the bulldog in popular opinion has for so long been regarded as the butcher's able assistant and the ruffian's faithful companion; but, owing to the interest its peculiar conformation affords to the science of breeding, it yearly gains more ground in civilised society by attracting the attention of men of better education.

However, before going right into the description of what a modern bulldog ought to be, some few particulars of his early history may be desirable, and it is said that the first record of bulldogs in England was in $16_{3} 1$, when one Prestwich Eaton, from St. Sebastian, wrote to George Wellingham, of St. Swithin's Lane, London, for a mastiff and two good 
bulldogs. But I believe that there must have been bulldogs in England long prior to the seventeenth century.

Bulldogs were ostensibly dogs for bull-baiting, and as this brutal diversion. was known to be in vogue as early as I 209, there must have been bulldogs then. Such animals as were used for actual work were quite unlike the modern manufactured article, which has undoubtedly suffered by the discontinuance of the amusement. There was no use for him with bulls, so he had to be bred for fancy purposes alone. Huge, broad heads became the rage, legs widely bowed were in favour, and from an active dog, that was able to seize a bull by the nose and keep his hold there, he has come to be an animal that has to go in training at a seaside resort before he is able to walk four miles an hour.

I must write of dogs as I find them at the present time, and, to show the state to which an endeavour to breed for exaggeration in certain points has brought the bulldog, reproduce the following account of a walking match between two crack bench winners, which took place in the summer of 1893. There had been a brindled dog shown with extraordinary success at that time, for which his owner, Mr. S. Woodiwiss, was reported to have given $£^{250}$-the greatest amount of money ever 
paid for a dog of this variety. In the opinion of many persons he was so much a cripple as to be unable to stand properly in the ring, which was a fact. However, the judges under whom the dog in question came, appeared blind to his defects, and time after time he was placed over more perfect animals. Then a match was made between Dockleaf, the dog above alluded to, and another well-known prize-winning bulldog, called King Orry, owned by Mr. G. R. Murrell.

The novelty of the contest caused considerable interest to be taken therein, and it was arranged under the following conditions: "Each dog to be led and make the best of the way from the Roebuck Hotel, Lewisham, to Bromley Town Hall and back, the distance being about ten miles. The competitors might have as much rest as appeared desirable, but 'lifting' from the ground was disqualification. At seven o'clock, when the start was made, a big crowd was in attendance, a portion of which accompanied the dogs on their journey. King Orry went off with the lead, and was nearly 400 yards ahead when a mile or more had been traversed. Soon after Dockleaf showed signs of fatigue, but continued on his journey to a couple of miles from the start, when, being fairly beaten, Mr. Woodiwiss withdrew him from further competition; his opponent was then far in 
front, and 'going well.' Mr. Murrell's dog, after a rest of seven minutes, arrived at Bromley Town Hall, and then set off on the return journey, Lewisham being duly reached at 9.25 p.m. Both animals had been in training for the match, and the winner showed no signs of distress after the accomplishment of what some modern admirers of the bulldog consider a great feat, but which we consider any bulldog ought to do equally satisfactorily. The loser occupied a trifle under forty minutes in covering his two miles, and, exclusive of stoppages, the winner progressed at the rate of some four and a half miles in the hour."

So much for the activity and working capacity of a bulldog that has been pronounced by some parties to be one of the best of his race ever exhibited. However, all bulldogs are not so unable to walk at a fair pace as was the case with this dog; still, he must be given as an example of the evil of breeding for certain exaggerations which nature could never have produced without human assistance, and of the curious decisions that often take place in the show ring.

As already observed, with the discontinuance of bull-baiting, following the passing of an Act for the prevention of cruelty to animals, in the year 1835 , came a lull in the production of the breed, and we 
read that at the commencement of the present century the "true" bulldog was very scarce. I have in my possession a painting (of which engravings are extant, dated May 15 th, I809), by H. B. Chalon, representing three bulldogs, Wasp, Child, and Billy. Of these dogs it was said they belonged to $\mathrm{Mr}$. $\mathrm{H}$. Boynton, were of the late Duke of Hamilton's breed, and the only ones left of that blood. Such dogs were so great in estimation that $\mathrm{Mr}$. Boynton refused I2O guineas for Billy, and 20 guineas for a whelp before taken from the bitch. It was further asserted at the time that they were " the only real bulldogs in existence, and that upon their decease that variety of dog may be considered extinct." Well, it is evident a bit of puffing could be done in those days, for the bulldog is now far from extinct, though Wasp and Child and Billy have long since departed for a happier home. Indeed, there are more bulldogs in existence at the present time than has ever previously been the case in our history.

Mr. Boynton's bulldogs were typical specimens, and one or two of them would have passed muster today. There is a white one with erect ears; another lying down, white with a patch, with rose ears; the third - the best of the bunch-a dark brindle and white with fair ears, but not so heavy and cumber- 
some in body, head, and limbs as is the case with the modern type. Perhaps from these dogs came the historical Crib and Rosa, pictures of which are seen in almost all the print shops, and the original of which was published in r8I 7. Many bulldog pictures are extant. One of the best I know is a coloured print of three bulldogs in Sydenham Edward's work on "The Dog," published in London, August, I 800 . Bingley in his "Natural History" gives us a big white dog with a patch on him, not unlike some of the best specimens of to-day, especially in body. The "Sportsman's Cabinet," I 803, gives us the picture of a dark brindled and white dog with a gaily carried stern, erect ears, and, to our educated minds of the nineteenth century, but a half-bred animal at the best. Reinagle painted this dog, but it is not so good a specimen as Chalon's, which came out a year or two later.

The picture of a bulldog in Youatt's book ( 1845 ) is peculiar, to say the least. It represents a white dog as big as a mastiff, with bowed legs, a " roach" back, short whip tail, and cow-shaped hocks. Still, he looks strong enough to pin a bull. However, about that time considerable attention was being given to the production of the British bulldog; but there was little material to work on, though there were enthusiasts in the cause even then, 
who mostly lived in London and in other large manufacturing centres. When dog shows began to exist, an impetus was given to all varieties of the canine race, the bulldog amongst the rest. Jemmy Shaw had kept some of the best blood in London; and old Ben White, who preceded the celebrated Bill George in his kennels at Kensal Town; Jacob Lamphier, of Birmingham; Charlie Stockdale, William M'Donald, London; James Hinks, Reeves, and Mr. Percivall, of Birmingham; Mr. Ashburne, Mr. Turton, all gave them attention, and to such men as these enthusiasts - if most of them were dealers-we owe what good bulldogs there are at the present time.

I think there is little doubt that from the time of J. Lamphier's King Dick - a red smut dog of about 481b. in weight, and certainly the best of his day, and one of the best bulldogs that ever lived, who was whelped in $185^{8}$, and died when eight years old-until within about eight years ago we had our very best bulldogs. These were active animals, such as could run after a dogcart, or, perhaps, pin a bull if it were required. The craze for breeding for exaggerated points-huge skulls and heads, unduly low fore quarters, with shoulders set on at right angles, and standing wider in front than the bull himself-was not so pronounced as it came to be 
somewhat later. Take, for instance, such dogs as King Dick (already alluded to), Crib (known as Turton's Crib, a brindle and white dog of $64 \mathrm{lb}$. weight, and as good an all-round specimen as was ever produced), Mr. P. Eden's Bend Or, Captain Houldsworth's Sir Anthony, Mr. T. Verrinder's Slenderman, Mr. J. H. Joyce's Bacchus, Bumble (known as the penny show dog, because he was first exhibited at a penny show in Birmingham), Mr. Shirley's Sancho Panza, Mr. Oliver's Monarch, Mr. R. J. Hartley's Venom, and many more good, sound, and active bulldogs could be named which flourished within the teens of years prior to about I 882 .

Perhaps here it will be well to mention that at the earliest London show classes were provided for Bulldogs over I 8lb. weight, and for others under I $8 \mathrm{lb}$. weight; sometimes the regulation was under and over zolb. The classes which included the smallsized dogs, were as a rule very well filled, on an occasion there being over forty dogs and bitches in the one division. These as a rule were typical little animals, thorough bulldogs in every way, but most of them, not all, had more than a tendency to carry their ears erect in ugly fashion. Whether this was the reason they lost their popularity I cannot tell, but gradually these small-sized bulldogs ceased to 
attract, and about i 870 the classes for them were discontinued. The London fancy mostly had had them in hand, Harry Orme, Bill Tupper, W. M'Donald all at one time or another showing good specimens; Violet, Floss, Frank, Tiny, and others being the chief prize winners. It has been said that some of our French visitors took a great fancy to these miniature emblems of British pluck, and through Tupper and Orme secured all the best specimens. Be this as it may, there are few under 2olb. bulldogs in Great Britain at the present time, whilst in the land of the Gaul such are by no means uncommon, and quite recently an endeavour has been made to reintroduce the strain here under the misleading name of "Toy Bulldogs." Now as our acknowledged weight of a toy dog is not more than from seven to eight pounds at the very most - six pounds is much the more correct weightI am surprised that there are show committees who will provide classes for these French bulldogs to be called "toys," going up to 23 lb. each in weight. At least this was the limit at a recent exhibition. The foreign specimens shown had enormous spoon-shaped ears, some of the exhibits were fairly well shaped as bulldogs though their expression more favoured the Schipperke. They were but sorry representatives of the type Billy Tupper was so fond of in the 
sixties. If we require these little bulldogs, there is better material at home for providing them than anything our French neighbours can send "perfidious Albion." A few excellent little animals of native growth are still to be found; moreover, there was that little bitch of Mr. Cyril Jackson's, Sally Scattercash, about 23lb. weight, who was proved sufficient of a bulldog to win prizes in her ordinary class. She had no bat ears and Schipperke characteristics, but did possess a pedigree, being by Monarch III., from his own mother, Skittles. Sally was bred by Mr. C. Bartlett, of Bath.

In the "good old days," about Sheffield and Birmingham, dishonest practices were in force, which were said to improve the face and muzzle of the bulldog. Cruel contrivances called " jacks" were fixed on to the muzzle in such a manner as to drive the nose back. Sometimes, too, the ears were cut, and the more recent case of the disqualification of Monarch when shown by Mr. D. S. Oliver at Birmingham, in 1880 , is not yet forgotten. Monarch had been shown successfully the year before, and was again awarded similar honours. After the judging, attention was called to the dog's ears, upon which were found certain marks which led to the animal's disqualification. Subsequent inquiry took place, and at a meeting held on. December 16 several experts 
were examined, who were unanimous in their opinion that the marks had been wilfully made whilst the dog was in the show, and Mr. Oliver was exonerated from all blame in the matter. He, however, took the dastardly action so much to heart as to completely sever his connection with the bulldog "fancy." Another dog of note known to be "faked" was F. Lamphier's Tiger, for which Mr. George Raper gave $£ 45$, well aware of the defects of his purchase, but he considered him cheap at the money for breeding purposes.

About this time, which may be called the middle period of the modern bulldog, Mr. F. Adcock-a most earnest admirer of the race-was upon the scene, and sometimes he had thirty or forty bulldogs in his kennels. He had an opinion that the British bulldog was degenerating physically and otherwise. He believed that the original bulldog was a heavy animal, and, as he could not find one to his liking in this country, took a journey into Spain. As the West had produced the wise men, so it was said Spain had produced the best dogs. Mr. Adcock brought back with him an immense animal, which he called Toro.

Now this dog was not so "black" as many persons painted him. Mr. Adcock had been yearning after big bulldogs, and even his great dog Ajax, 
which scaled 65 lb., and was good enough to win at Birmingham in 1872 , did not satisfy him. So, as before hinted, he went to Spain to seek for a bigger animal, with the result above stated. However likely Toro was to improve the bulldogs of this country, and his appearance led one to believe that he would do so, at stud he proved a complete failure. This was unfortunate, for then, an introduction of new blood would have been very useful, especially so far as improving the activity and strength of the modern article. And Toro was an active dog. He may have been a "fluke" somehow or other, for if his parents, or one of them, or his uncles or aunts, or grandparents had been as good as he, he must have got better stock than was actually the case. Personally, I considered Toro an exceptionally fine dog, and would prefer him to many of the leading winners of the present day. What he resembled will be seen from the following description from the Field at that time: "Toro is a huge, massive dark chestnut or 'carroty' brindled dog, with blackish muzzle; he has very deep flews, high temples, large nostrils, and is very much underhung, and, for his size, short in the face. His eyes are tolerably full, and a good deal of the white is shown; the 'stop,' or indentation between the eyes, is large and deep, and runs high up the head. The skin about 
the head is very loose, and falls into wrinkles and folds when the ears of the dog are erected; and a deep double dewlap runs from the angles of the mouth to the sternum. His ears have been cut out, very little of the burr being left, and this greatly detracts from the apparent size of his head. His neck is arched, short, very thick and muscular, and covered with quantities of loose skin; the shoulders broad and flat at the top, standing well out from the ribs, and very muscular; the elbows well out from the ribs; the forearm very thick, and slightly bowed; feet large and round, and furnished with very strong claws; the chest is great, and not only broad, but deep, and the ribs are very round. There is a considerable fall at the shoulders, and from that point the loins begin to rise, the arch terminating at the insertion of the tail. This is placed very low, has a downward crook at the root and another at the end, is very short and fine in bone, and is never erected so high as the level of the dog's back. The loins are strong and muscular, as are also the hind quarters, the stifles turning out slightly, and the hocks rather close together. The whole of the hind quarters are small, as compared with the fore quarters, and are considerably higher. The coat is very fine and smooth, and the hair very hard in texture. In showing condition Toro weighs golb. The follow- 
ing are his exact measurements: Head, 22in.; chop, close up to eye, I 4 in.; length of face from corner of eye to tip of nose, $2 \frac{1}{2}$ in.; from corner of eye down to angle of mouth, 5 in. ; between eyes, $2 \frac{3}{4}$ in.; from ear to ear across forehead, $5 \frac{1}{2}$ in.; from top of nose to

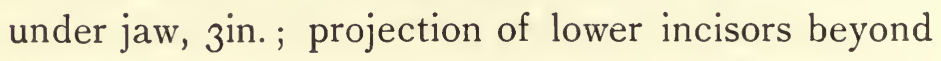
those in the upper jaw when the mouth is closed, in.; between canines in upper jaw, $2 \frac{3}{16} \mathrm{in}$.; in lower jaw, about 2in., being broken; round neck, Igin.; length of neck, 5 in.; round ribs, 3 Iin.; across chest, I 3 in.; between forelegs, 9in.; length of neck and body from apex of skull to root of tail, 3oin.; round forearm, $8 \frac{1}{2}$ in.; round loins, $2 \mathrm{I}$ in.; height at shoulder, $22 \mathrm{in}$; from point of elbow to ground, I in.

"Toro, although very forbidding in appearance, is exceedingly quiet and docile, and is possessed of great intelligence; he retains all the peculiar attributes of the ancient British bulldog-such as size, courage, \&c. He will only pin an animal by the head, and when fighting is perfectly silent and utterly regardless of pain. $\mathrm{He}$ is rather slow in his movements, has a rolling kind of gait, and carries his head low."

Although Toro has not handed down any of his excellent qualities to present generations, I should say that heavy weight bulldogs are more numerous now than was the case then. At the leading shows 
we see some half dozen bulldogs or more that vary from $55^{\mathrm{lb}}$. to $65_{5} \mathrm{lb}$. in weight, and these big dogs, which usually have special classes provided for them, if not proportionately so massive in head as the medium-sized animals, are, as a rule, more active on their legs and smarter generally in their movements. Of course, in dwelling so much on the matter of activity, I do not mean to infer that a bulldog should be as lithe and smart in his action as a fox terrier. Still, he must be able to walk and run a bit, which he does with a peculiar roll, which is all his own.

About the same period-a little later and a little earlier perhaps-that Mr. Adcock was proving unsuccessful in producing bulldogs as big and active as he desired, others were working away on a somewhat different line, and with greater success. These were, in addition to those already named who came earlier, Messrs. Bill Page, Frank Redmond, Rivers Wilson, and Billy Shaw, of London; Messrs. Peter Eden and John Henshall, of Manchester; Mr. W. H. Tyser, Mr. R. Fulton, Mr. T. Verrinder, Mr. H. Layton, Mr. A. Benjamin, Mr. J. W. Gurney, with Messrs. R. J. Lloyd Price, S. E. Shirley, G. Raper, J. W. Berrie, J. Ure, Dundee; H. Munro, Hull; R. J. Hartley, \&c. At one time or another, and during a period extending over almost two generations, the British bulldog must be indebted to the 
above gentlemen for the position and excellence it holds at the present time.

Some of them were dealers, others were amateurs; but all worked with the same object in view, and, I should say, have attained their end. Jacob Lamphier at one time had the lead, and, at any rate, he made his mark by possessing two such good dogs as King Dick and Romanie, the latter purchased by Mr. Lloyd Price for $£^{\mathrm{I}} 5^{\mathrm{O}}$-an enormous sum then for a bulldog, as it is now. Unfortunately, Mr. Price was not so successful as he deserved, for, after winning first prize at Birmingham in $186_{5}$, on his journey to the next show poor Romanie was found smothered in the guard's van. F. Lamphier's Crib (brindled), Jesse Oswell's Dan (a white dog, particularly handsome for a bulldog), Mr. John Henshall's Duke (another white dog, bred by the Duke of Hamilton), Mr. R. Fulton's Falstaff, Mr. Lloyd Price's Michael the Archangel (another white $\mathrm{dog}$, and historical in his way because eaten during the siege of Paris in $187 \mathrm{I})$, Mr. Clement Butler's Stead, Mr. Henshall's Juno, Mr. F. Lamphier's Meg and Rush, Mr. G. A. Dawes' Maggie Lauder, Mr. Verrinder's Poll, were about the best specimens that flourished from twenty to twenty-five years ago, and there are few modern bulldogs, if any, which do not contain the strain of one or another of them. 
Coming a little later, we find such good dogs as Mr. Sellon's Diogenes and Mischief, Mr. G. Raper's Rustic King and Rustic Model, Mr. J. H. Ellis's Grabber (who died at the good old age of twelve years as this is being written), Guido and Saleni, Mr. S. Woodiwiss's British Monarch and Dryad, Mr. P. Beresford Hope's Bedgebury Lion (who went to America, where he did not survive many months), M. J. B. Gheud's (Brussels) Leonidas, Mr. Benjamin's expatriated Britomartis, Mr. G. Fowler's Monkey Brand, Mr. Cassel's Facey Romford, Mr. Smith's Ruling Passion, Mr. Drew's Kitty Cole, Mr. J. Morris's (afterwards Mr. Sellon's) Queen Mab, the black and tan marked King Orry, Mr. W. G. Smartt's Punch, Mr. H. Pebody's Found It, and there may be others pretty nearly as good as some of the above, the names of which will be found in any show catalogue.

So much for some of the most notable dogs I have known, and, however incomplete the list may be, it is, at any rate, sufficient to prove that the British bulldog is not in any danger of becoming extinct, so far as this country is concerned. If further proof of the popularity of the bulldog be needed, such will be found in the carefully compiled volume of bulldog pedigrees, the editors of which - Messrs. Cyril Jackson and E. H. Bowers-tell us 
they have catalogued the names of about 6000 bulldogs. The difficulty of tracing the pedigrees of many of these may be inferred from the fact that the volume contains no fewer than sixty-five bulldogs that bear or have borne the well-known name of Crib. We may, indeed, be able to draw fresh crosses from the United States, for, of late, admirers of the race there have purchased some of our best specimens - including the bitch Britomartis and Bedgebury Lion and Leonidas.

A word must be said as to one or two matters relating to the variety which have caused considerable difference of opinion amongst admirers of the bulldog, and first and foremost comes the question of so-called "Dudley faces." Dogs that have flesh-coloured noses, with which light-coloured eyes and generally yellowish-looking countenances are often associated, are called "Dudley" because such animals originally came from that part of the Black Country known as Dudley, which is in Worcestershire. Personally, where a dog is otherwise good, I would not disqualify him for his Dudley markings; but I must confess to being in the minority whilst holding such an opinion. Then occasionally split-nosed or double-nosed bulldogs are met with, and where such is the case I would do no more than severely handicap the dog bearing the blemish. As a fact, I 
would far rather have a Dudley marked or split-nosed dog that could move well, than the most perfect bull$\mathrm{dog}$ in the world whose locomotion is about equal to the pace of a man with gout in both feet.

From time to time the bulldog has been used as a cross, with an idea of putting extra courage in other varieties of the dog which it was thought required pluck to a greater extent than they possessed in their purity. This has in part only proved successful, and I should say where it was tried in the case of greyhounds proved entirely unsatisfactory. With the terrier it has been more useful, resulting in the modern bull terrier-a handsome white dog, which for gameness, good nature, and adaptability as a companion has no superior.

As a sporting animal-i.e., as a vermin destroyer, and as a hunter after hares or rabbits-our bulldog is a failure. Not that he is quite without the use of the ordinary olfactory organs, for he can hunt the footsteps of his master pretty well as cleverly as any other dog, but they are not so fully developed as in the case of hounds, terriers, \&c. Still, Charles St. John in his "Highland Sports" tells of a hunting bulldog that was once in his possession. As his is such an unusual story of an animal of this kind, I'will allow the author, who was always so reliable, to tell his tale in his own words. 
He says: "I at one time had an English bulldog who accompanied me constantly in deer stalking. He learned to crouch and creep up to the deer with me, never showing himself, and seemingly to understand what I wished him to do. When necessary, I could leave him for hours together alone on the hill, when he would never stir until called by me. If a deer was wounded, he would follow the track with untiring perseverance, distinguishing the scent of the wounded animal, and singling it out from the rest, never making a mistake in this respect. He would also follow the stag till he brought him to bay, when, with great address in avoiding the horns, he would rush in and seize him either by the throat or the ear, holding on till I came up, or, as he once did, slaughtering the animal, and then coming back to show me where he had left it."

This pleasant writer then describes how this bulldog hit the line of the wounded stag after other dogs had failed to do so, how he ran the scent, and ultimately returned bleeding to his owner, and with an ugly gash in his side. Then he took the party through thick woods, over rough ground, to where the stag, with his throat torn open, lay dead at the foot of a rock. Those of the party who had declared the dog fit only to "kill a cat or pin a bull," were now lavish in their praise of him, would have given 
almost untold gold for him, but, said St. John, "we were too old friends to part, having passed many years together, both in London, where he used to live with my horses and run with my cab, and also in the country, where he had accompanied me in many a long and solitary ramble over mountain and valley." Mr. F. Adcock says that some of his bulldogs would hunt a hedgerow as well as a terrier, and were equally as good at retrieving from water.

The above prove that the bulldog, which has obtained such an evil character for ferocity, may, under proper training and surroundings, become as companionable as any other dog. $\mathrm{He}$ is very faithful to his master, and his appearance is certainly worse than his disposition. When he has the chance he is quite as sociable as most dogs, his temper is reliable, and, on the show bench, he may be petted and caressed by the stranger with far less likelihood of being bitten than would be the case with the terriers and collies. Then he is not addicted to barking too much, is not liable to run away, when kept in the country, on hunting excursions; but he is not built on the proper lines to follow a dog cart or run after a bicycle.

So far as companionship with man is concerned the bulldog's lot has not always been a happy one. In his early days, as I have said, he was kept for 
the purposes of bull-baiting, it being a popular fallacy that "bull beef" was tenderer and more palatable when cut from a bull that had been made angry and worried by dogs. As a fact, in some localities such meat was not allowed to be displayed for sale without being labelled "bull beef," unless the animal from which it came had been "baited" prior to being slaughtered. In modern days the bulldog is valued for amusement and for show purposes, and when making his living on the benches he is, in nine cases out of ten, kept in a kennel along with other dogs of the same breed, and seldom given the social advantages which fall to the more fortunate St. Bernard, terrier, or collie. Perhaps there may be a happier day for the British bulldog in this particular, especially that he has now a couple of well supported specialist clubs to look after his welfare.

One thing there always will be against the actual popularity of the bulldog, and that is the great difficulty there is in breeding first-rate specimens, and, with very few exceptions, our best bitches are wretched mothers, in some cases refusing to breed at all, in others failing to suckle the puppies, and in others the puppies often enough are born dead. Inbreeding, huge heads, and malformation of chest and forelegs are no doubt responsible for this state of 
things, nor is it likely matters will improve in this particular at any early date. Two of the most notable exceptions to this difficulty in breeding from good bitches are to be found in Mr. T. Ball's Susan and Mr. E. Farman's Ruling Passion, whose success where other equally good bitches have failed make them worthy of mention here.

The principal collection of bulldogs to be found in this country is the exhibition periodically held by the Bulldog Club (established in 1875), who held their twentieth gathering in 1893 . Here an entry of something like a couple of hundred is usually found, containing, no doubt, all the best dogs of the day. The classification is, of course, particularly complete, and includes divisions for dogs $45^{\mathrm{lb}} \mathrm{b}$ weight and over; classes for bitches $35 \mathrm{lb}$. weight and over, and light weight classes below the above standards There are divisions for dogs over $55 \mathrm{lb}$. for bitches over $45 \mathrm{lb}$.; for dogs between these two weights and for bitches between $35 \mathrm{lb}$. and $45 \mathrm{lb}$; others for dogs under $45^{\mathrm{lb}}$. weight and for bitches under $35^{\mathrm{lb}}$. Such is the usual weight classification, but there are other divisions provided, in which no weight is stipulated. The Bulldog Club has also four challenge cups, two of them worth fifty guineas each, and two of the value of twenty guineas each. 
The British Bulldog Club, established in I892, already a strong body, is likewise great in special prizes, having two $£ 50$ challenge vases and two $£ 25$ cups, and two Io-guinea goblets for puppies. Both clubs are well to do so far as membership is concerned, and in other particulars, whilst each has carefully drawn up a distinct description of what a bulldog should be.

For the following very complete description of a typical bulldog I am indebted to Mr. Cyril F. W. Jackson, of Bath, who also kindly assisted me in the early portion of the chapter.

"In judging a bulldog the general appearance is of all importance, for, though it is of course necessary to give each point in detail, still the eye once accustomed to the impression made by the appearance of a dog of this breed true to type, will almost unconsciously recognise the following salient points. The immense skull, the protruding under jaw, the grotesque facial angle, to be seen in no other breed, the massive neck, and the extraordinary disproportion of the girth of the brisket as compared with that of the waist, the prodigious width of chest, the shortness of the body, the roach back, the shortness from the elbow to the pastern, the malformation of the tail, and, lastly, the disparity in weight of the fore part with that of the hind, all contributing to build 
up a dog, probably presenting to the casual observer more individuality than any other breed, save perhaps a bloodhound or a basset hound. The habit of some judges of allowing themselves to be biassed by one point of superexcellence in the specimen they have to pass their opinion on, is distinctly wrong, as a show specimen should be of uniform merit throughout, and should not excel in one point more than another.

"The head is one of the important characteristics of the variety; its appearance should be one of striking massiveness in proportion to the animal's size as well as compared with that of any other animal. It cannot be too large so long as it be square, that is to say, it must not be wider than it is deep; it should be of great depth from the occiput to the base of the lower jaw, of as great circumference as possible, squarely shaped, and must not be in any degree wedge shaped, dome shaped, or peaked. Of course the head of a female is never as large or so well developed as that of the male, and this remark applies to nearly every point throughout. The jaws should be broad, massive, square, and powerful. The lower jaw should project considerably beyond the upper jaw, though I regret that this point is by no means insisted upon by many judges, as some notable prize winners lately have been almost level jawed. 
"Whilst casting history to the winds, it appears to me that points emblematic of the now obsolete function should be preserved, and it is very certain that a protruding under jaw was a point very strongly insisted on by old time breeders, as it enabled their dogs to breathe whilst pinning the bull's nose. It must be admitted that when carried to excess this feature is very unsightly on the show bench, which probably accounts for the growing tendency to countenance 'froggy' specimens. The face, by which is meant all that part of the animal which is in front of the eye, should be extremely short, with broad truncated muzzle, distinctly inclined upwards, which must occur if the formation of the lower jaw is correct. By the expression "froggy" is meant a dog with level jaws, that is to say, not underhung, though in some few cases it even amounts to being overshot. The terms "wry faced" or "twisted jawed" are synonymous, and denote that the lower jaw has the appearance of being contorted. This deformity, though a great eyesore, does not exist in the bone, but in the soft structures forming the lower half of the face. I have proved this by examining the skulls of "wry faced" dogs, in none of which was there assymmetry. I believe this "wry face" to be caused by injury at the time of the birth of the puppy, and that it is not hereditary. 
"The face should be broad in proportion to the skull, otherwise the animal is called 'pinched faced,' and deep through the muzzle, or otherwise the animal is what is called 'monkey-faced.' When viewed in profile it should appear as if the tip of the nose would just touch an imaginary straight line drawn from the extremity of the lower lip to the frontal eminence between the brows. The bones of the lower jaw in specimens which have the desired appearance, known as 'upturn' and 'lay back,' are found to have the contour of a segment of a circle. No other colour looks well for the lips than black, and nothing spoils the appearance of a white dog so much as not having entirely black lips.

"'The upper lip, called the 'chop,' should be very thick and deep, hanging completely over the lower jaw at the sides, but only just joining the lower lip in front, yet quite covering the teeth, otherwise the dog is said 'to grin.' On the thickness of the 'chop' depends the amount of 'cushion,' a point very much sought after by modern exhibitors. Some, however, are of opinion that it is very undesirable to have the chops large to the point of being pendulous. For my part I think that the appearance of a dog is enhanced by very deep chops, so long as they are of a good thickness; but what spoils the appearance of a dog is having long thin 
chops like a bloodhound's flews. The teeth should be large and strong, the tusks should be wide apart, the front teeth between the tusks should be regular, which they very rarely are, and in most bulldogs the incisors of the lower jaw are mere apologies for teeth.

"The nose must lie well back, the tip being set nearly back to the 'stop,' and should be broad, large, deep, and perfectly black. Of all the bulldogs I have seen all have had smooth noses if they have been in health, and the only authority I know of who admires a rough nose in a bulldog is $\mathrm{Mr}$. Frank Adcock. The nostrils should be large and wide, with a well-defined straight line visible between them; but a split septum or nostril may be taken as an absolute disqualification under any judge nowadays, and what is very much more common is a defect in one wing of the nose, which makes the two nostrils dissimilar, and is looked upon by many judges as a serious blemish. A parti-coloured nose, which is called a 'butterfly' nose, handicaps the animal, while few judges would have the temerity to place a dog with a 'Dudley' or flesh-coloured nose in the prize list.

"What is known as the 'stop' is the indentation in the bone at the junction of the forehead and the face. It is a point of great importance, and should 
be very deep. From this 'stop' there should be a deep, broad furrow, extending upwards between the brows, gradually disappearing when the occiput is reached.

"The expression 'well broken up' is used where this 'stop' and furrow are well marked, which, if accompanied with a quantity of loose and wellwrinkled skin about the head, give the animal's expression style and finish. The term 'lay back' is often confused with what is meant by 'stop.' 'Lay back' is the facial angle, and can only be properly ascertained by viewing the dog side face, whereas 'stop' can only be appreciated looking a dog full in the face, or, better still, by feeling the skull with one's two thumbs. The brows should be prominent, square, broad, and high. The occiput should be flat from ear to ear; the forehead large but flat, not overhanging the face, and of great breadth when compared with the height from the nasal bone to the occiput. The cheeks rounded, extending laterally beyond the eyes, and the cheek tumps well defined-points which probably are not fully developed until the third year.

"There is only one style of ear admitted by judges as being correct nowadays, and that is the shape known as 'rose,' which, by the way it is folded, laps in an outward direction, exposing some 
part of the burr of the ear. The most objectionable form of ear is undoubtedly the 'button,' in which the tip falls forward, hiding the inside of the ear, as with fox terriers. What I consider a far less objectionable ear is the pricked or 'tulip' ear, because until quite recent years all the best specimens had them, and, moreover, in many cases they merely betoken a very large development of muscle in the jaw, whereas the 'button' ear, being invariably a coarse one, is diametrically opposite to what is by general consent required, viz., smallness and thinness. The ears must be placed at the top edges of the skull, far from the eyes, and wide apart, so as to give an appearance of breadth to the skull between them, but if they are placed too low there is always a slight look of 'appleheadedness.'

"A good deal of a bulldog's appearance depends on whether his eyes are correct or not, though most writers appear to treat the subject as an unimportant one, contenting themselves by simply saying they should be dark. First, as regards position, they should be placed low down, but quite in front of the forehead, as far from the ears, from the nose, and from each other as possible so long as their outer corners are within the outline of the cheeks. They must be at right angles to the furrow before described, and only a little above the level of the 
base of the nasal bone. They should be quite round, fairly large, neither sunken nor protruding, and intensely dark, showing no white when looking directly forward; in fact, in the correct bulldog eye the dark brown colour of the iris seems to have run into the sclerotic, which fact accounts in some measure for the white of the eye not being seen.

"There is another phenomenon which is very typical of the breed that deserves notice, and that is an indescribable dark blue glare, seen especially when a bulldog is excited. I believe that the best word to express this is opalescence. The light hazel or yellow eyes that are now becoming prevalent are to be deprecated, there being a strong connection between them and Dudley noses. The deformity known as 'wall-eyed,' i.e., one eye of a lighter colour than the other, or eyes in which the iris is whitish, very light grey, or defective in colour, or eyes in which the whites are very large or distorted, is now very rarely seen, probably because it has been so persistently stamped out for many years.

"What is required in the neck is that it should be thick set, deep, muscular, and short, but of sufficient length to display an arch. The more it is furnished with thick loose skin forming a double dewlap for some distance downwards from 
the under jaw, the greater is the degree of character imported to the dog. The ribs should be of great depth and breadth, being well sprung, and should come far down between the fore legs to give ample space for the lungs and heart. The chests of many specimens lately exhibited have been of amazing width, an appearance added to by the immense development of the deltoid muscles, and this is certainly a point in the breed which every owner is anxious to produce even to exaggeration. Unless the shoulder blades are put on low, it is obviously impossible to obtain the desired width across the chest, therefore in good specimens it is found that the tops of the shoulder blades are never touching or even close together. Contrary to what is required in other breeds, the shoulder blades of a bulldog should slope considerably and not be vertical.

"The belly should be well tucked up, and not pendulous, a small narrow waist being greatly admired, it being a great object to obtain a large circumference just behind the shoulders, and the smallest possible one round the waist, which forms the appearance called 'cut up.' The back rises from behind the shoulders in a graceful curve, which curve reaches its summit over the top of the loins, and thence falls away rapidly to the stern, thus 
forming what is known as the wheel or roach back, which is essentially a characteristic of the breed, though very often wholly absent from many of the most successful dogs of the present time; and worse still is the endeavour to palm off dogs which are ' rump high' or 'stern high' as being 'roached ' backed, whilst the difference is that the 'stern high' dog rises in an almost straight line from behind the shoulder to the setting on of the tail.

"It is very noticeable that bulldogs are bred year by year shorter and shorter in the couplings, entirely replacing the long, low shape of former years by one as compact as possible. The tail should be set on low, deflecting slightly downwards, moderately short, thick at the root, tapering quickly to a fine point, should be devoid of 'feather,' not curved upwards at the end, called 'ring tailed,' and should be incapable of being raised above the level of the backbone, which is called a 'gay' carriage, a feat only possible to such tails as have no 'kınks' (kinks are really congenital dislocations of the joints of the tail). The screw tails, which are so peculiar to the breed, are objected to by a few authorities as indicating excessive in-breeding, an assumption which I venture to doubt.

"Of the limbs and feet the forelegs should be as wide apart as possible, very thick, stout, and strong, 
straight, and short. This great strength, muscularity, and immense bone are innovations of modern times, as our forefathers who kept bulldogs apparently were satisfied with limbs no thicker than pipe stems. How much of this abnormal growth of bone is the result of rickets in puppyhood is hard to say.

"Here again is evidence of a departure from what was admired, and sought after, but a very few years ago. I refer to what was called 'a pear-shaped front,' an expression which signified that the dog's chest across the shoulders when viewed from in front was very wide, that his fore legs appeared as if bowed, and that his pasterns nearly touched. But such a conformation is now denounced by nearly every judge of the breed, though I myself regret that 'pear-shaped fronts' are now deprecated so strongly. I admit that a dog so formed is bound to have a 'wobbly' action when travelling, but it was a characteristic of the breed. Further, it had this advantage, that a dog so shaped in front was always allowed to stand naturally in the ring, whereas nowadays it is quite common to see dogs with their front legs deliberately propped as far apart as possible by their owners in the judging ring, so much so that judges have to lift dogs gently off the ground in front by their chain and collar, so as to allow their front legs to assume a 
natural position. The bitch Ruling Passion, and the dog Royal Rogue, were typical specimens of the "pear-shaped front."

"The elbows should be set on low, turned outwards, standing well away from the ribs, so as to permit the body to swing between them, and giving the legs the appearance of being loosely tacked on the sides of the body. It is probable that the great depth of the ribs between the forelegs makes the forelegs look shorter than they really are. The thick covering of muscle which is found on the outside of the forelegs of many of the most typical dogs conveys.a suspicion of bow leggedness, which would be a great fault. The knee in an adult animal is hidden by a thick coating of flesh and muscle. The pasterns should be short, stout, straight, upright, and strong, not everted so much as in many of the wide-chested but knock-kneed dogs. The fore feet straight, round, rather large, not turning inwards in the least, and turning outwards only very slightly, with toes thick, compact, and well split up to the knuckles, the latter being prominent and high.

"The hind legs, though of slighter build than the forelegs, should be strong and muscular; they are distinctly larger than the forelegs so as to elevate the loins above the level of the top of the shoulders. The stifles should by their covering of muscle 
appear rounded, and should stand slightly away from the body, thus inclining the hocks inward and the hind feet outward, but not 'cow hocked,' which is always a sign of bad rearing, and is a serious impediment to freedom of movement. The hocks should be well let down, moderately straight and low, giving great length from the hip to this joint, and making the pastern short, but not so short as those of the fore legs. The hind feet rather smaller than the fore feet, and turned decidedly outward; they are generally supposed to be required round and compact, but, as a matter of fact, are nearly always longer and more hare footed in shape than the fore feet. The toes certainly look best if split up and if the knuckles are prominent.

"The coat should be of fine texture, close and smooth; silky when stroked from head towards tail and hard, owing to its closeness, but not wiry when stroked in the reverse direction. There have been cases lately where dogs have been shown with peculiarly long hair about the withers, but this is decidedly ugly.

"The colour ought to be brilliant, and preferably should contain one of these colours either pure or mixed, viz., white, brindle, red fawn, or fallow, but the two last are considered by, some as 'weak' colours, and a whole coloured dog is most generally 
admired. Some authorities maintain that black and tan should absolutely disqualify, though such opinion has not lately always been upheld; thus a black and tan awarded a prize by one judge has been disqualified by another. It is not possible to dispute a dog being a black and tan if he has 'beauty' and 'kissing' spots. With the exception of black and tan, black and white, black, blue slate, all of which are objectionable, colour is a matter of little importance, and in cases of equal merit in other respects anyone may be guided by his own fancy. In cases where the predominating colour is white with only small patches of black and tan, I myself see no reason why the dog should be discarded.

"In looking at the symmetry, carriage, and gait of a bulldog from in front one should be struck by the great breadth and depth of its fore parts, which should gradually taper off to the stern, as the bulldog should present as much as possible to view in front of his shoulders and as little as possible behind them.

"A bulldog in stature should be low on the ground, more so in front than behind, the body being carried between and not on his forelegs. The height of its toreleg, from the ground to the elbow, should not exceed the distance from the elbow to the centre of the back between the shoulder blades. Consider- 
able weight attaches to the freedom and activity displayed by the animal in its movements as well as the extraordinary roll in its gait; by activity is meant. not that of a terrier but a freedom of movement proportionate to the massiveness of the animal's formation, and, although there is a peculiarly constrained manner of gait natural to the breed, which is caused by the big, heavy head, chest, and shoulders, and by the greater height of the hind legs as compared with that of the fore legs, still, surely it is not too much to expect an animal whose progenitors were capable of performing such deeds of daring and endurance, unless deserving of being called a cripple, to be able at least to follow his master in his daily walks. Anything approaching deformity, weakness, or crippledness is rightly considered highly objectionable, though this point does not appear to be always clearly ascertained.

"The average weight of bulldogs is now from 4 olb. to 5 olb., and of bull bitches $35^{\mathrm{lb}}$. to $45^{\mathrm{lb}}$., but dogs have been shown as heavy as $65 \mathrm{lb}$. within the last three years.

"In disposition the bulldog is never treacherous; if he is savage there is no disguise of the fact, and he is then a very undesirable possession. If well brought up he is the best of companions, safe with children, and most forgiving of their tricks, capable of 
being taught to retrieve by land or water, and by his perfect manners ingratiating himself in any household. That most bulldogs are impulsive and impetuous at any sudden emergency there is no doubt, but they are easily restrained, and obey commands. A bulldog without animation, apparently disregarding insult or injury, is a pitiable object."

The numerical points would be as follows :

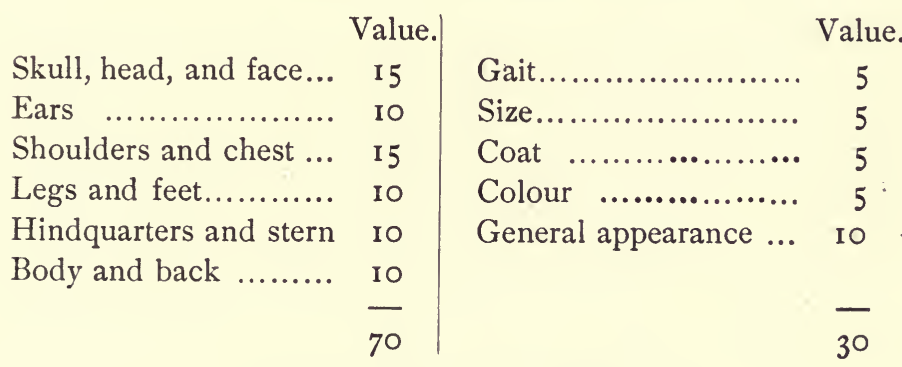

Grand Total, 100.

Following the precedent I have formed in other chapters, I give the description the leading specialist club (the Bulldog Club) have issued of their special variety :

"In forming a judgment on any specimen of the breed, the general appearance-which is the first impression the dog makes as a whole on the eye of the judge-should be first considered.

"Secondly should be noticed its size, shape, and make, or rather its proportions in the relation they 
bear to each other (No point should be so much in excess of the others as to destroy the general symmetry, or make the dog appear deformed, or interfere with its powers of motion, \&c.) Thirdly, his style, carriage, gait, temper, and his several points should be considered separately in detail, as follows, due allowance being made for the bitch, which is not so grand or as well developed as the $\operatorname{dog}:-$

"I. The general appearance of the bulldog is that of a smooth-coated, thick-set dog, rather low in stature, but broad, powerful, and compact. Its head strikingly massive, and large in proportion to the dog's size. Its face extremely short. Its muzzle very broad, blunt, and inclined upwards. Its body short and well-knit; the limbs stout and muscular. Its hind quarters -very high and strong, but rather lightly made in comparison with its heavily made foreparts. The dog conveys an impression of determination, strength, and activity similar to that suggested by the appearance of a thick-set Ayrshire or Highland bull.

" 2 . The skull should be very large-the larger the better-and in circumference should measure (round in front of the ears) at least the height of the $\operatorname{dog}$ at the shoulders. Viewed from the front, it should appear very high from the corner of the 
lower jaw to the apex of the skull, and also very broad and square. The cheeks should be well rounded and extended sideways beyond the eyes. Viewed at the side, the head should appear very high, and very short from its back to the point of the nose.

"The forehead should be flat, neither prominent, nor over-hanging the face; and the skin upon it and about the head very loose, hanging in large wrinkles.

" 3. The temples or frontal bones should be very prominent, broad, square, and high, causing a deep and wide groove between the eyes. This indention is termed the 'stop,' and should be both broad and deep, and extend up the middle of the forehead, dividing the head vertically, being traceable at the top of the skull.

" 4. The eyes, seen from the front, should be situated low down in the skull, as far from the ears as possible. Their corners should be in a straight line at right angles with the stop, and quite in front with the head. They should be wide apart as possible, provided their outer corners are within the outline of the cheeks. They should be quite round in shape, of moderate size, neither sunken nor prominent, and in colour should be very darkalmost, if not quite black, showing no white when looking directly forward. 
" 5. The ears should be set high in the head-i.e., the front inner edge of each ear should (as viewed from the front) join the outline of the skull at the top corner of such outline, so as to place them as wide apart, and as high and as far from the eyes as possible. In size they should be small and thin. The shape termed 'rose ear' is the most correct. The 'rose ear' folds inward at its back, the upper or front edge curving over outwards and backwards showing part of the inside of the burr.

"6. The face, measured from the front of the cheekbone to the nose, should be as short as possible, and its skin should be deeply and closely wrinkled.

"The muzzle should be short, broad, turned upwards, and very deep from the corner of the eye to the corner of the mouth.

"The nose should be large, broad, and black, its top should be deeply set back, almost between the eyes. The distance from the inner corner of the eye (or from the centre of the stop between the eyes) to the extreme tip of the nose should not exceed the length from the tip of the nose to the edge of the under lip.

"The nostrils should be large, wide, and black, with a well-defined straight line between them.

" 7. The flews, called the 'chop,' should be thick, 
broad, pendent, and very deep, hanging completely over the lower jaw at the sides (not in front). They should join the under lip in front, and quite cover the teeth, which should not be seen when the mouth is closed.

" 8. The jaw should be broad, massive, and square, the canine teeth, or tusks, wide apart. The lower jaw should project considerably in front of the upper, and turn up. It should be broad and square, and have the six small front teeth between the canines in an even row.

"The teeth should be large and strong.

"9. The neck should be moderate in length (rather short than long), very thick, deep, and strong. It should be well arched at the back, with. much loose, thick, and wrinkled skin about the throat, forming a dewlap on each side from the lower jaw to the chest.

"The chest should be very wide laterally, round, prominent, and deep, making the dog appear very broad and short-legged in front.

" Io. The shoulders should be broad, slanting, and deep, very powerful and muscular.

" I I. The brisket should be capacious, round, and very deep from the top of the shoulders to its lowest part where it joins the chest, and be well let down between the fore legs. It should be large in 
diameter, and round behind the fore legs (not flatsided, the ribs being well rounded). The body should be well ribbed up behind, with the belly tucked up, and not pendulous.

" I 2. The back should be short and strong, very broad at the shoulder, and comparatively narrow at the loins. There should be a slight fall in the back close behind the shoulders (its lowest part), whence the spine should rise to the loins (the top of which should be higher than the top of the shoulders), thence curving again more suddenly to the tail, forming an arch-(a distinctive characteristic of the breed)-termed 'roach-back,' or more correctly 'wheel-back.'

"' 3 . The tail, termed the 'stern,' should be set on low, jut out rather straight, and then turn downwards, the end pointing horizontally. It should be quite round in its own length, smooth, and devoid of fringe or coarse hair. It should be moderate in length-rather short than long-thick at the root, and tapering quickly to a fine point. It should have a downward carriage (not having a decided upward curve at the end or being screwed or deformed), and the dog should, from its shape, not be able to raise it over its back.

"I4. The fore legs should be very stout and strong, set wide apart, thick, muscular, and straight, 
with well-developed calves, presenting a rather bowed outline, but the bones of the legs should be large and straight, not bandy or curved. They should be rather short in proportion to the hind legs, but not so short as to make the back appear long or detract from the dog's activity, and so cripple him.

"The elbows should be low, and stand well away from the ribs.

"The ankles, or pasterns, should be short, straight, and strong.

"The fore feet should be straight, and turn very slightly outward, of medium size, and moderately round.

"The toes compact and thick, being well split up, making the knuckles prominent and high.

" I 5. The hind legs should be large and muscular, and longer in proportion than the fore legs, so as to elevate the loins.

"The hocks should be slightly bent and well let down, so as to be long and muscular from the loins to the point of the hock.

"The lower part of the leg should be short, straight, and strong.

"The stifles should be round, and turned slightly outwards away from the body. The hocks are thereby made to approach each other, and the hind feet to turn outwards. The latter, like the fore feet, 
should be round and compact, with the toes well split up and the knuckles prominent.

"From his formation the dog has a peculiar heavy and constrained gait, appearing to walk with short quick steps on the tip of his toes, his hind feet not being lifted high, but appearing to skim the ground, and running with the right shoulder rather advanced, similar to the manner of a horse in cantering.

"16. The most desirable size for the bulldog is about 5 olb.

"I 7. The coat should be fine in texture, short, close, and smooth (hard only from its shortness and closeness, not wiry).

"Its colour should be whole or smut (that is, a whole colour with a black mask or muzzle). The colour should be brilliant and pure of its sort. The colours in their order of merit, if bright and pure, are, first, whole colours and smuts-viz., brindles, reds, white, with their varieties, as whole fawns, fallows, \&c. ; second, pied and mixed colours." 



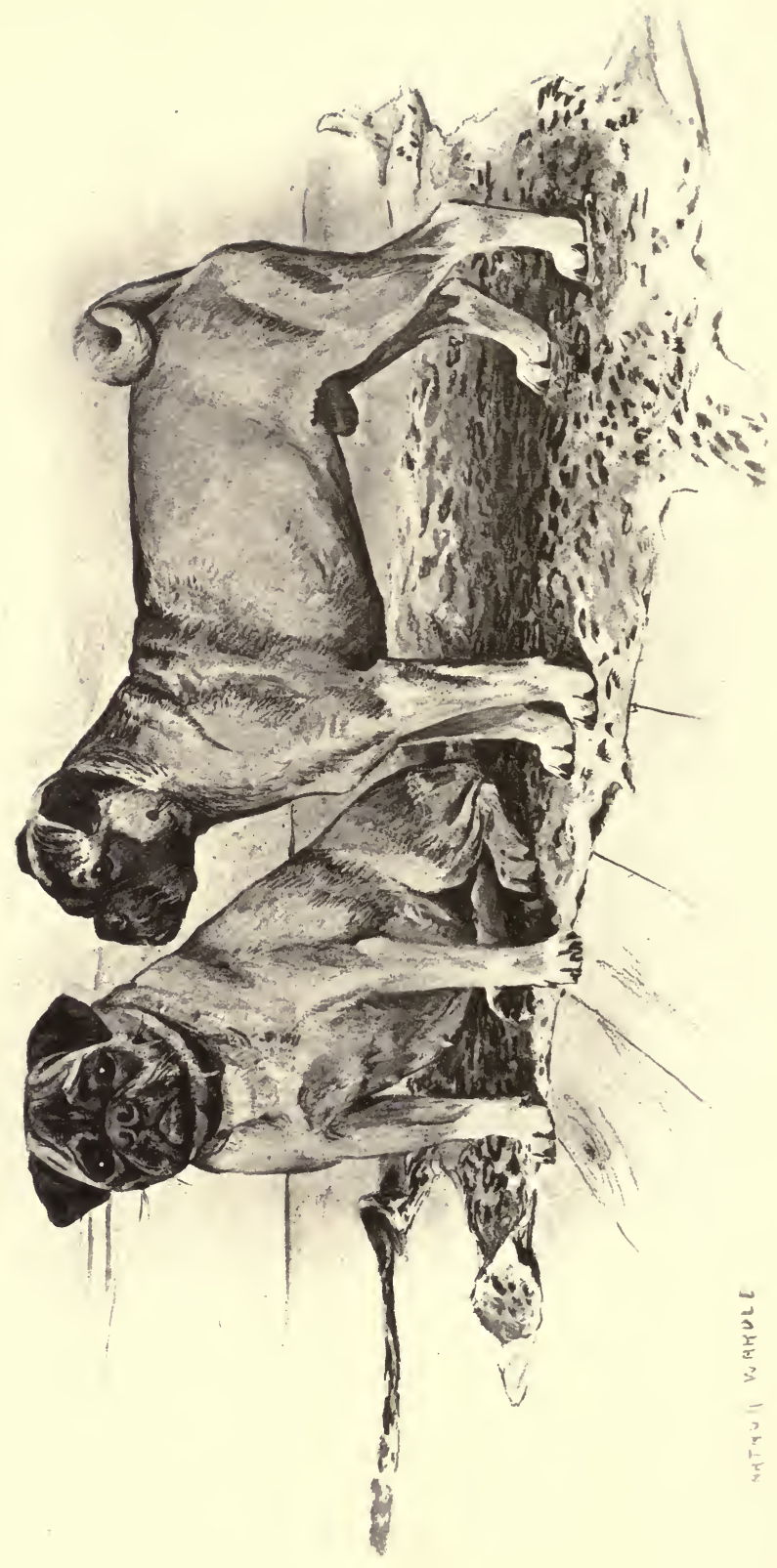




\section{CHAPTER $\mathrm{X}$.}

\section{THE PUG.}

Notwithstanding what some writers have said to the contrary, I believe that little change has been made in the appearance and in "the points" of the pug during the past forty years. Twenty years ago "Idstone" (the Rev. T. Pearce) said there were not half a dozen good specimens to be found in the country, and that a quarter of a century before he wrote the pug was the rarest of all "toy dogs."

I must, however, take exception to the remarks of that pleasant writer, for when he published his book of the dog, pugs of great excellence were to be found in considerable numbers throughout the length and breadth of the land, nor at any time within the present century have they been so rare as either the Italian greyhound, the Maltese terrier, or even as the Yorkshire terrier. Unfortunately, prior to the introduction of dog shows, cruel custom had insisted that the pug dog looked most lovely when robbed of its ears. They were not merely cut off and artistically 
trimmed, as is the common practice with the bull terrier and one or two other varieties at the present time, the pug's ears were shorn off, and rounded close to the head; so close, indeed, in some instances, as to give the impression, which was curiously believed to be correct, that they had been torn out by the roots. The vagaries of fashion are certainly most difficult to comprehend, and why a delicate lady's pet dog should have been tortured in this way there is not the slightest reas on to show Fighting dogs had their ears cut off to prevent their offering a hold for the teeth of an opponent; ears of terriers had been cut to produce a smarter and brighter appearance, and perhaps the tail had been docked in the first instance under the vulgar superstition that the "distemper worm" was thereby destroyed! A pug with the ears shorn off was rendered hideous, though may be its profile thus looked more like the shadow of a clenched fist than it would with the ears on; the pug no doubt obtaining its name from the Latin word pugnus, a fist.

The pug has never been claimed in this country as a native breed, but was supposed to have been a native of Holland, and even to this day is sometimes called the Dutch pug. As it happens, at present more of them are with us now than is the case in any other country on the Continent, although the pug 
has a wide range, extending pretty much from the east to the west of Europe. In France and Italy it is a favourite with the ladies, and at one period of its existence, but for a short time only, it was known in the former country as the Carlin, owing to its black mask or muzzle, a name given it in honour of a popular harlequin named Carlin. This, of course, was but a passing fancy, and prior to Carlin's popularity they had been known as doguins or roquets, but afterwards they obtained the commoner, if less euphonious name of pugs.

The "Sportsman's Cabinet" ( I 804) gives an illustration of the pug drawn by Reinagle: a cropped dog with a black mask, curled tail, and toying with a much smaller specimen, which, also being cropped, cannot well be a puppy. Thus the inference is conveyed that when the drawing was made there were pugs of two quite distinct sizes, one of which may probably have been $\mathrm{I} 4 \mathrm{lb}$. or more, the other not more than half that weight. Unfortunately, the letterpress accompanying the illustration is meagre in the extreme, if not actually vague. It says that it is asserted by some that the "genuine pug was introduced to this island from Muscovy, and they were originally the undoubted natives of that country. Others assert the pug to have been produced by a commixture between the English 
bulldog and the little Dane, calling such races simply mongrels, as coming from the mixture of two pure races. . . In the whole catalogue of the canine species there is not one of less utility, or possessing less the powers of attraction than the pug dog. Applicable to no sport, appropriated to no useful purpose, susceptible to no predominant passion, and in no way remarkable for any extra eminence, he is continued from era to era for what alone he might have been originally intended-the patient follower of a ruminating philosopher, or the adulating and consolatory companion of an old maid."

The above is rather rough on the poor little pug, but such an unfair and ungallant description could only have emanated from the brain of a rough sportsman of the old school, whose chief delights would lay in badger drawing, bull baiting, and cock fighting. The pug dog has its uses in society, and possesses credentials as a lady's dog that cannot be excelled, of which, however, more later on.

With such a comparatively modern $\operatorname{dog}$ as the pug there should be inore about him to be learned, but history is silent on the subject. Some say that he is descended from the bulldog; others that the bulldog has been improved by an infusion. of pug dog blood into him. I have never met anyone who has made the cross either one way or the other, but 
I should not be surprised to find that during the early part of this century some of the small-sized bull bitches were mated with a pug dog in order to produce that fawn or "fallow smut" bulldog which some fanciers admire very much indeed. But if the cross ever was there, such has been so carefully bred away that nothing of it remains, excepting, may be, in the hue of our national canine representative. Such bulldogs as Guido and Queen Mab have, perhaps, as nearly as anything approached the pug dog in hue, but although they are fallow or fawn smuts, there is nothing about their character or appearance to indicate in the slightest degree that pug blood might be running in their veins.

As to the origin of the pug, Buffon, one of the most unreliable of naturalists, says that the pug is but a "modified bulldog" from the Cape of Good Hope, it being imported into Holland when the Cape was a Dutch settlement, and soon became a favourite pet with the ladies. That the country which has since been responsible for the Schipperke also gave us in the first instance our pugs, I have no doubt whatever. It was very fashionable in England soon after the accession of our William III., he and Queen Mary II., no doubt bringing sundry specimens over with them as part and parcel of their retinue. History tells us that 
the pug became first favourite at the Dutch Court in the time of the father of our William III. who, like others, had enemies. One night, whilst camping out, he was wakened by the scratching and barking of his pug dog, which had been aroused and rendered furious by the appearance of a party of pikemen, who sought the life of the Prince. Two of his attendants were killed, but otherwise the murderous attempt was baulked through this watchfulness and vigour of the canine guard. If such were the case, and history is not always truthful, there is little to wonder at the favouritism of the pug, although it did no more than any other dog would have done under similar circumstances. The quaintlooking, courtly little dogs were quite the rage for a time, but I fancy that for one reason or another they did not make a great deal of headway in Britain, possibly because in-breeding had made them delicate. However, every now and then some fresh blood was introduced from both France and Italy, as well as from Holland, and so the breed was continued, although it did not become particularly common; still, there were plenty of pugs to be found up and down the country, and they were fairly installed one of our own varieties.

About the time Hogarth, the great painter, flourished, Dutch pugs were as fashionable as black 
pages, and no lady of title was considered to be fully equipped unless she had both in her following. Although the painter himself cannot be said to have been a man about town or a creature of fashion, still he kept his pug dog-at least, it is generally understood that the dog which appears in the best known portrait of the artist is intended to be a pug, and the fashionable breed in that day; to me it seems but a nondescript creature.

In due course special strains came to be produced, and Lady Willoughby de Eresby, of Grimsthorpe, near Lincoln, and Mr. Morrison, of Walham Green, gave particular attention thereto. Of those strains "Stonehenge" says :-

"After a great deal of trouble a dog was obtained from Vienna which had belonged to a Hungarian countess, but was of a bad colour, being a mixture of the stone fawn now peculiar to the 'Willoughby strain,' and black; but the combination of these colours was to a certain extent in the brindled form. From accounts which are to be relied on, this dog was about twelve inches high, and of good shape, both in body and head, but with a face much longer than would be approved of by pug fanciers. In I 846 he was mated with a fawn bitch imported from Holland, of the desired colour, viz., stone fawn in body, with black mask and trace, but with no indi- 
cation of brindle. She had a shorter face and heavier jowl than the dog, and was altogether in accordance with the type now recognised as the correct 'Willoughby pug.' From this pair are descended all the strain named after Lady Willoughby de Eresby, which are marked in colour by their peculiar cold stone fawn, and the excess of black often showing itself, not in brindled stripes, but in entirely or nearly entirely black heads, and large 'saddle marks' or wide 'traces.'

"But coincidently with this formation of a new strain was the existence of another, showing a richer and more yellow fawn, and no tendency to excess of black. This strain was possessed by the late $\mathrm{Mr}$. Morrison, of Walham Green; the late Mr. H. Gilbert, of Kensington; the late Mr. W. M'Donald, and some others. According to Mr. Morrison's statement to me, this strain was lineally descended from a stock possessed by Queen Charlotte, one of which is painted with great care in the well-known portrait of George III. at Hampton Court; but I could never get him to reveal the exact source from which it was obtained. That he himself fully believed in the truth of this story I am quite confident; and I am also of opinion that he never hazarded a statement of which he had the slightest doubt. Although he never broadly stated as much, I always inferred that 
the breed was obtained by "back-stair influence," and on that account a certain amount of reticence was necessary; but, whatever may be the cause of the secrecy maintained, I fully believe the explanation given by $\mathrm{Mr}$. Morrison of the origin of this breed of pugs, which is as commonly known by his name as that of Lady Willoughby de Eresby by hers. His appeal to the Hampton Court portrait, in proof of the purity of his breed from its general resemblance to the dog in that painting, goes for nothing in my mind, because you may breed up to any type by careful selection; but I do not hesitate to indorse his statemeut as to the Guelph origin of his strain, because I have full confidence in his truthfulness, from having tested it in various other ways. I need scarcely remark that both strains are derived from the Dutch-'the Morrison' coming down to us through the three Georges from William III., and 'the Willoughby' being, as above described, a more recent importation direct from Holland and Vienna."

I need scarcely say that neither of the above strains is to be found in its purity at the present day, no pains having been taken to keep them distinct, but there are as many good pugs now as ever there were. In the family of the Willoughby de Eresby's no pugs have been kept for ten or a 
dozen years. An early edition of "Dogs of the British Isles" contains an engraving from a painting, of two pugs, the original stock from which the "Willoughbys" were bred. They are both fair specimens, perhaps standing rather higher on the legs than is liked at the present day, but otherwise quite typical animals, and they have their ears cropped. About fifteen years ago there was a newspaper warfare, in which one side argued that the pug had already degenerated or was degenerating; but as is usual in controversies of this kind, nothing of interest appeared, although perhaps some good resulted by attention being drawn to the great size of many of the leading winning pugs. Dogs from $20 \mathrm{lb}$. to perhaps $24 \mathrm{lb}$. weight or more were often enough seen at the head of the prize lists, which of course was not to be borne quietly by those who were showing animals not more than $18 \mathrm{lb}$. in weight, which as a fact is quite big enough, and it is gratifying to find that the Pug Dog Club, which was established in 1883 , expresses an opinion strongly against the over-sized specimens.

Although pugs had classes provided at the first show which included non-sporting dogs at Birmingham, in I86I, strangely enough there was no competition, but since then divisions arranged for them have been respectably filled. In 1885 , and 
with one exception ever since, the pug club has had a show of its own, though sometimes it has taken place in amalgamation with that of other Toy Dogs and Toy Spaniels. In I 886 classes were provided for dogs under and over I $8 \mathrm{lb}$. weight each, and for bitches under and over I 5 lb., but at the more recent gatherings the restriction as to size isdogs, I 5 lb. weight, and bitches I 4 lb. weight, thus completely ousting the bigger animals, which are certainly out of place as pugs, for there is no elegance in a large-sized specimen of this variety. In $1887 \mathrm{Mr}$. H. G. Foster's Comedy, known as the immense Comedy, which weighed probably 24lb., was given the first prize at the National Show at Birmingham.

I think a pretty good idea of what a pug should be, is given in the drawing by Mr. Wardle which precedes this chapter. As a companion in the house, and for an occasional run into the country, no dog is better fitted than the pug. $\mathrm{He}$ is cleanly in his habits, has a pretty, soft coat, and nice skin; no foul smell hangs about him, and he is gentleness itself. He shows no ill-temper or moppishness, and the objectionable lolling out of the tongue and unpleasant snorting, which at one time were so common in this variety, is quickly disappearing. Of several pugs that I have owned or known, not more 
than one of them was addicted to either of these unpleasant habits. All were lively and tractable, and if not actually as intelligent as a highly-trained poodle, one pug I knew was quite accomplished in many little tricks he used to perform. No doubt had a professional trainer taken this little dog in hand it would have been able to earn more than its own living on the stage. Again, a pug can remain sweet and healthy on less open-air exercise than any other dog, and two of them will play about the dining room or nursery and amuse themselves as much as two terriers would by a scamper in the green fields.

The pug is not a hunting dog, except so far as tracking the footsteps of his fair mistress is concerned, but he has been known to take to the unladylike occupation of killing rats, which he has done as well as a terrier. Still, it is no part of the duties of a lady's lap-dog to soil his pretty mouth by contact with the most obnoxious of creatures, because we all know that perhaps the next minute he may be fondled and caressed by his owner. Although I have said a pug dog can do with comparatively little out-door exercise, still, he is better for as much as he can be given, for no dog has a greater tendency to put on fat, and reach a state of obesity, than the one of which I write. Whoever 
saw a pug dog thin and gaunt, with its ribs and backbone almost sticking through the skin? He always looks smooth, contented, and comfortable, eats well, and he should have as little meat and fat-producing food as possible. Some writers have given him the reputation of stupidity, but I do not believe him deserving of such an epithet. In the house and out of doors he is as sensible as any other dog, follows well in a crowd when properly trained, and is no more liable to lose himself than an ordinary terrier. Some friends of mine had what they called a pug, but she was not more than half or three-parts pure bred, who was particularly sensible. She would retrieve, kill rats, was fond of the gun, and liked a ride on the 'bus or tramcar so well that she continually would take one on her own account, which the kindly conductor allowed her to have gratuitously, the conditions of the "tram" company notwithstanding. This dog had the curly tail, fawn colour, and general appearance of a pure-bred animal, excepting that she was rather long in face. She lived to a great age, but as a rule the pug is not the longest lived of the canine race.

For a long time there was a fallacy abroad that the sex of the pug could be determined by the carriage and curl of the tail, the dog having his over on the right side and the bitch on the left. As a 
matter of fact, I have repeatedly observed dogs with the curl to the left, and bitches with theirs to the right. Sundry peculiarities in the pug are that it is essential for the toe nails to be black (this is often overlooked by the judges), and that they should have a black mole or spot on each cheek. Of course, all dogs have the latter, but in the pug it is much more clearly defined than is the case in other varieties. The dark trace along the back is another peculiarity, as is, of course, the quaintly-curled tail.

During the past few years the best specimens have been bred by, or in the hands of, Mr. J. Nunn, London; Mrs. Mayhew, Twickenham; Mrs. Bligh Monk, Coley Park, Reading; Mrs. J. Foster, Bradford; Miss Lea, near Chichester; Mr. W. L. Sheffield, Birmingham; Mrs. Hartley, Nelson; Mrs. Westfield, near Sheffield; Mrs. T. Proctor, Leeds; Mrs. Horner, near Kirkby Lonsdale; Mrs. C. Houlker, Accrington; Mr. R. T. Linton, Edinburgh; the Rev. G. C. Dicker, Birkenhead; Mr. T. T. Craven, Leeds; Mr. H. Maule, Scarborough; Mr. W. B. Garniss, Ashbourne; Mr. T. Dunn; Miss Hamilton, Seend, Wiltshire; and Mrs. Brittain, Durham.

The Pug Dog Club has issued the following description and points of the variety; such must be taken as the standard, and a very good standard, too. The club is a thoroughly representative body, 
and has two twenty-five guinea challenge cups at its disposal, as well as other valuable trophies.

Symmetry.-Symmetry and general appearance, decidedly square and cobby. A lean leggy pug and a dog with short legs and a long bory are equally objectionable.

Size and Condition.-The pug should be multum in parvo, but this condensation (if the word may be used) should be shown by compactness of form, well-knit proportions, and hardness of developed muscle. Weight from I 3 lb. to i $7 \mathrm{lb}$. (dog or bitch).

Body.-Short and cobby, wide in chest and wellribbed up.

Legs.-Very strong, straight, of moderate length, and well under.

Feet.-Neither so long as the foot of the hare, nor so round as that of the cat; well-split-up-toes, and the nails black.

Muzzle.-Short, blunt, square, but not upfaced.

Head:-Large, massive, round--not apple-headed, with no indentation of the skull.

Eyes.-Dark in colour, very large, bold and prominent; globular in shape, soft and solicitous in expression, very lustrous, and, when excited, full of fire.

Ear.-Thin, small, soft, like black velvet. There are two kinds-the "rose" and "button." Preference is given to the latter. 
Markings.-Clearly defined. The muzzle or mask, ears, moles on cheeks, thumb-mark or diamond on forehead, back-trace should be as black as possible. Mask. - The mask should be black. The more intense and well defined it is the better.

Wrinkles.-Large and deep.

Trace.-A black line extending from the occiput to the tail.

Tail.-Curled tightly as possible over the hip. The double curl is perfection.

Coat.-Fine, smooth, soft, short and glossy, neither hard nor woolly.

Colour.-Silver or apricot-tawn. Each should be decided, to make the contrast complete between the colour and the trace and the mask.

\section{The Standard Points.}

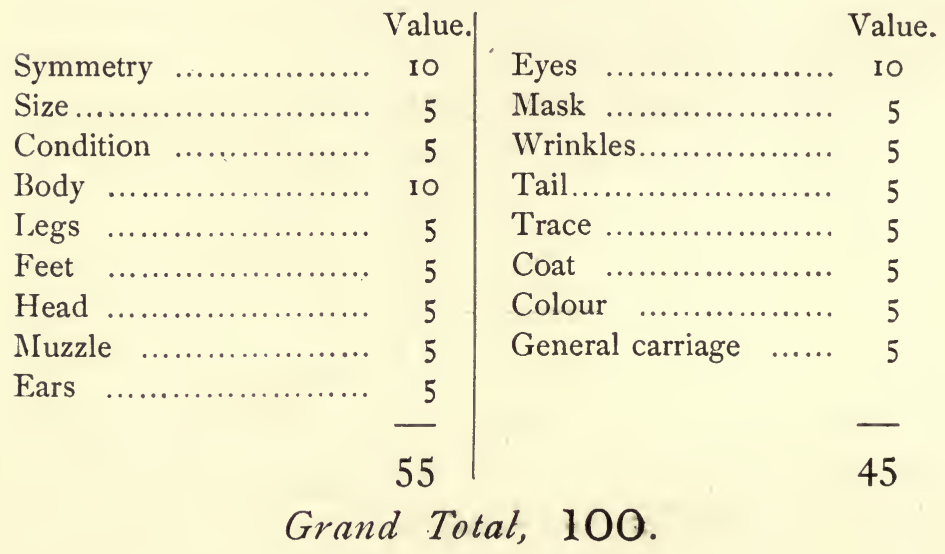





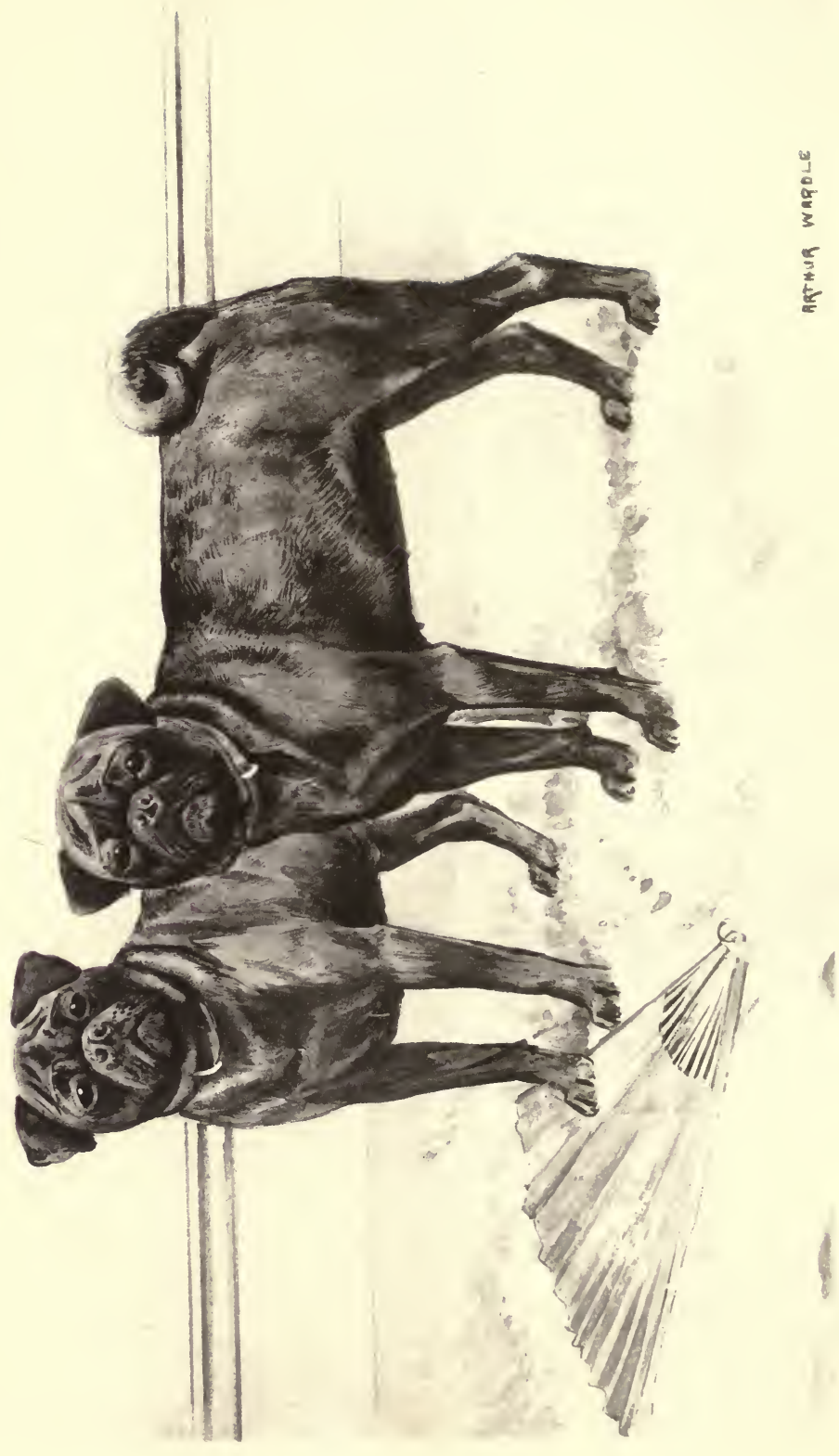




\section{CHAPTER XI. \\ THE BLACK PUG.}

HERE is a new variety, which has certainly appeared and obtained identity as such within the past two or three years, although we must go back a little further for the time when a few specimens were occasionally exhibited in our show rings; these being the property of the late Lady Brassey, and they were first shown at Maidstone in 1886 . Perhaps to form a direct contrast to these early specimens, some kind of an attempt had been made to produce white pugs; but herein success was not achieved, the nearest approach thereto being one that a couple of years ago was shown in New York, and another sent to the Birmingham show in 1892 , by Miss Dalziel, of Woking, but neither was of that snowy whiteness which one would require, and both I should take to be more "sports" than anything else. Still I do not see any reason why white pugs could not be produced by judicious crossing with the palest fawn specimens, with a slight dash of white bulldog or bull terrier to assist matters. However, this is digression. 
It seems strange that with such a modern variety of dog there should be serious doubts about its origin, and there are certainly differences of opinion on the matter. On one side it is stated to have come from the North of China, and that Lady Brassey brought a specimen therefrom when she was touring round the world in her yacht, the "Sunbeam." Again it is said the breed first sprang up accidentally, it being a "sport" produced in the north of London by one of the working fanciers in that locality, who had a particularly dark-coloured strain of the ordinary pug. Mrs. W. H. B. Warner, of Northallerton, at the close of 1893 , showed a little black dog which she had brought from Japan, where it was said to be of a rare and choice breed. This is nothing else than a long-coated pug-i.e., pug in character and shape, but with a jacket such as is seen on a Pomeranian. But there is no reason to doubt that in the East there are as many varieties of the $\operatorname{dog}$ as we have here. However, it is only in place that this latest of importations should be mentioned here. In, however, suggesting that our black pugs may have come from some such dog as this, it must not be forgotten that they have very short and thin jackets, the antipodes of this little fellow of Mrs. Warner's.

Personally, I believe there may be truth in both 
statements, that a black pug was accidentally produced, and at the same time a specimen or two had been brought from the East. Although Lady Brassey makes no allusion to a black pug in her published journals of the voyage of the "Sunbeam," still I know as a fact that two or three similar dogs were on her yacht, but whether they were then called black pugs is another question. More likely they were known as Chinese pugs.

A writer in a recent number of Black and White says: "It is rather unfortunate that the late Lady Brassey should have allowed the origin of the new pug to remain a mystery, but there seems little doubt that it hailed from China, as in a weekly contemporary, only the other day, I saw a copy of an advertisement which had been appearing in the North China Daily News: 'Lost, near the Hong Kong and Syezchen Roads, last evening, a small Peking Pug, black body and head, white paws. Anyone finding same will be rewarded on bringing it to Kelly and Walsh, Limited, Shanghai:' The white paws were evidently uncommon, and were the lost dog's distinguishing marks. I have also learned that a lady in the West End bought a black pug bitch from a sailor on one of the cargo ships just in the docks from China. Another lady at Willesden also bought 
one in the same way. This one was, however, unfortunately burnt in a fire, and before the purchaser had bred from her; but it is an undoubted fact that these pugs came off a Chinese vessel just arrived in port, and were sold to them as Chinese pugs. One lady describes hers as 'very short in face, good curl tail, and a beautiful jet black'-a perfect pug in points. Again, I have heard of a 'Chinese pug' being bought at Portsmouth from a ship calling there.

"It is, therefore, not improbable that Lady Brassey's black pugs Jack Spratt and Mahdi were brought home from China by Lady Brassey, and were of the breed mentioned in that stray advertisement for a lost pet, viz., a 'Peking ' pug."

That the variety is, at any rate, now quite a distinct one I do not doubt at all, for the following reasons. Mrs. Fifield, of Eastleigh, Southampton, who has some excellent specimens, which originally came from the Brassey strain, says that when blacks are mated together they breed true to type and colour, although in almost every litter a perfectlymarked grey specimen appears, but Mrs. Fifield never bred a black one from grey parents. Most of the blacks have, however, a little patch of white on the chest or toes, but others are perfectly black. Miss "Mortivals" (Miss M. D. 
Robinson), Takeley, Essex, writes in a similar strain, and as these two ladies have had a greater experience of black pugs than any one else, their opinions must be highly valued. Indeed, they, with Mr. Alfred Bond, of Gravesend, appear to be the only persons who have given much attention to the variety, and to them all credit is due for the improvement brought about in the appearance of the animal since it first came upon the scene.

The black pug is now a more cobbily and thickly-made dog than was the case three or four years ago; he is lower on the legs, and his head, face, and skull are more characteristic of our own pug dog, and he is likely in the future to breed quite as true to type as any other of our modern varieties; thus in due course he will popularise himself.

Although it was not until 1886 that black pugs first appeared at our shows, long before this time Lady Brassey had them at Normanhurst. A pair were given to a lady in Liverpool. Lord Londonderry was likewise presented with a specimen, and later I hear that Her Majesty the Queen took one, amongst her other canine companions, to Balmoral, on the usual royal visit to the Highlands. The royal pug, which bore the name of "Brassey" in honour of its donor, died at Windsor in $189 \mathrm{I}$, and, so 
far as I can learn, not one of these four animals left any progeny behind.

After Lady Brassey's tragical death in the Southern seas in 1887 , several of her black pugs were purchased by Mr. A. Bond, already alluded to. One of these dogs was Jack Spratt, who is said to he pretty well the progenitor of the present strains, though of course other blood was introduced. Mr. Bond had the misfortune to lose Jack Spratt in 1888 , both he and Bessie Spratt falling victims to that scourge of the pet dog, inflammation of the lungs. Fortunately, ere this occurred, Mr. Bond had been successful in rearing Lino, from Jack and Bessie Spratt, a handsome black dog, which he subsequently sold to Mrs. Fifield, of Southampton, and which has since sired the notable Doatie Darling and Black Gem, two of the best blacks we have had. What had become of Nap. II.-Lady Brassey's especial favourite-and his sister Black Bess, no one could find out, until the Crystal Palace Committee, in their show for I 89I, provided two classes for black pugs. Then for the first time Normanhurst Nap, who had become the property of Miss "Mortivals," met his brother, the Gravesend Lino, who beat the old favourite. Singularly, the first prize went to quite an outsider, believed to have come from the East End of London, as breeder and pedigree were stated 
unknown and the type had nothing of the Jack Spratt about it.

This dog, Nigger, now better known as Surprise, attracted, however, the attention of the judge, and its black coat, tightly curled tail, coupled with a smart carriage, quite overbalanced his somewhat long, terrier-like face, and placed him first in the open class for dogs, in which there were twelve entries. The other dogs shown, the true lineal descendants of Jack Spratt were so shy as to render themselves ridiculously unassertive, their tails dangling under their bodies, so they were quite out of the running. Nap II., however, was consoled by winning the first stud medal ever given to a black pug, he being awarded one of the two bronze medals offered by the Crystal Palace for stud pugs. These two wellfilled classes of odd-looking, but remarkably handsome, jet black pugs created considerable attention, and since that time classes have been provided for them at our leading exhibitions. Such is all that is known as to the history of the black pug.

I have already alluded to their breeding true to type, and Miss "Mortivals" says that "two of the original pair, Nap II. and Black Bess, never produced any puppies but black ones, which had usually a small white mark on their chests, and some of them had white on their toes, others on 
their under lip. A fawn bitch mated with Nap invariably threw half the litter wholly black, the others very clear coated-never fawns-with dense markings. I found the breeding, difficult, so about eighteen months ago I made up my mind to breed out for fresh blood, and accordingly purchased a first-class fawn bitch, combining the blood of Loris, Stately, and Diamond, and mated her with Nap II. At the same time I sent out a black daughter of Nap's to the fawn dog Confidence.

"From these alliances have been produced puppies either entirely black or entirely silver fawn, and not so mixed in coat as the show dogs of two fawn ancestors. Never yet has there appeared anything curious in the breeding, the sole reason for introducing the fresh blood being to make the blacks more like the fawns in quality, in shortness of face, better in body and lower in the leg. The issue from the Nap II., Loris, and Confidence alliances or blend, retains the colour, but have better coats, thicker in texture than that of the old blacks, and more inclined to ruffle, while the domed head is disappearing and giving place to wrinkle; sturdy limbs are supplanting the long taper legs of the original blacks, and the nose, instead of having a downward tendency, is becoming more snub.

"From the two cross alliances six puppies came, 
four of which were dense black, one pure silver, and one silver fawn of the loveliest colour possible. The coats and 'pug points' were much improved, and with one exception all had excellent jackets, characteristic of the fawn pug (the black had nearly always bad coats), and with loose skins. One of the strange things in this cross is that whole colours usually appear, and that black and fawn or tri-coloured puppies have not yet been born."

Mrs. Fifield and Miss "Mortivals" both accord the black pugs excellent characters. They say they are hardier than the fawn, especially when past puppyhood, and even when young they are not much trouble to rear. Oily food suits them best, and Miss "Mortivals" gives hers linseed once a week, it improving their coats and making them appear smarter and cleanlier than they would without it.

Mrs. Fifield writes that "the black pugs differ materially from the fawns; firstly they are not so susceptible to cold. The prettiest sight I remember was seeing the delight of an exquisite litter of black puppies in their first snowstorm; they simply revelled in it. They are much more tenacious in affection, for, while the fawns freely make friends, no enticements will induce the blacks to leave their owners, and, although very timid, they are wonderfully intelligent and easily learn tricks. They are cleanly 
in their habits, but, whilst the fawns are proverbially greedy, the blacks are extremely dainty feeders. A combination of such excellent traits makes them the most perfect companions ladies can possibly wish for."

I think I have produced sufficient evidence to satisfy carpers that no wrong has been done in introducing in this volume the Black Pug as a distinct variety. The evidence of those who keep him proves this, not only because the blacks are, even in disposition, unlike the fawns, but because the former breed equally true to type as the latter.

So far as the points and description are concerned, excepting in colour the two should be alike, but whether by introducing the "fawn" strain one or two of the distinguishing traits in the blacks may be ultimately lost is a question upon which there may be two opinions. The blacker the black pug is the better; he should be free from white, and any brown or bronze tinge is a very severe handicap when being judged in the ring. 



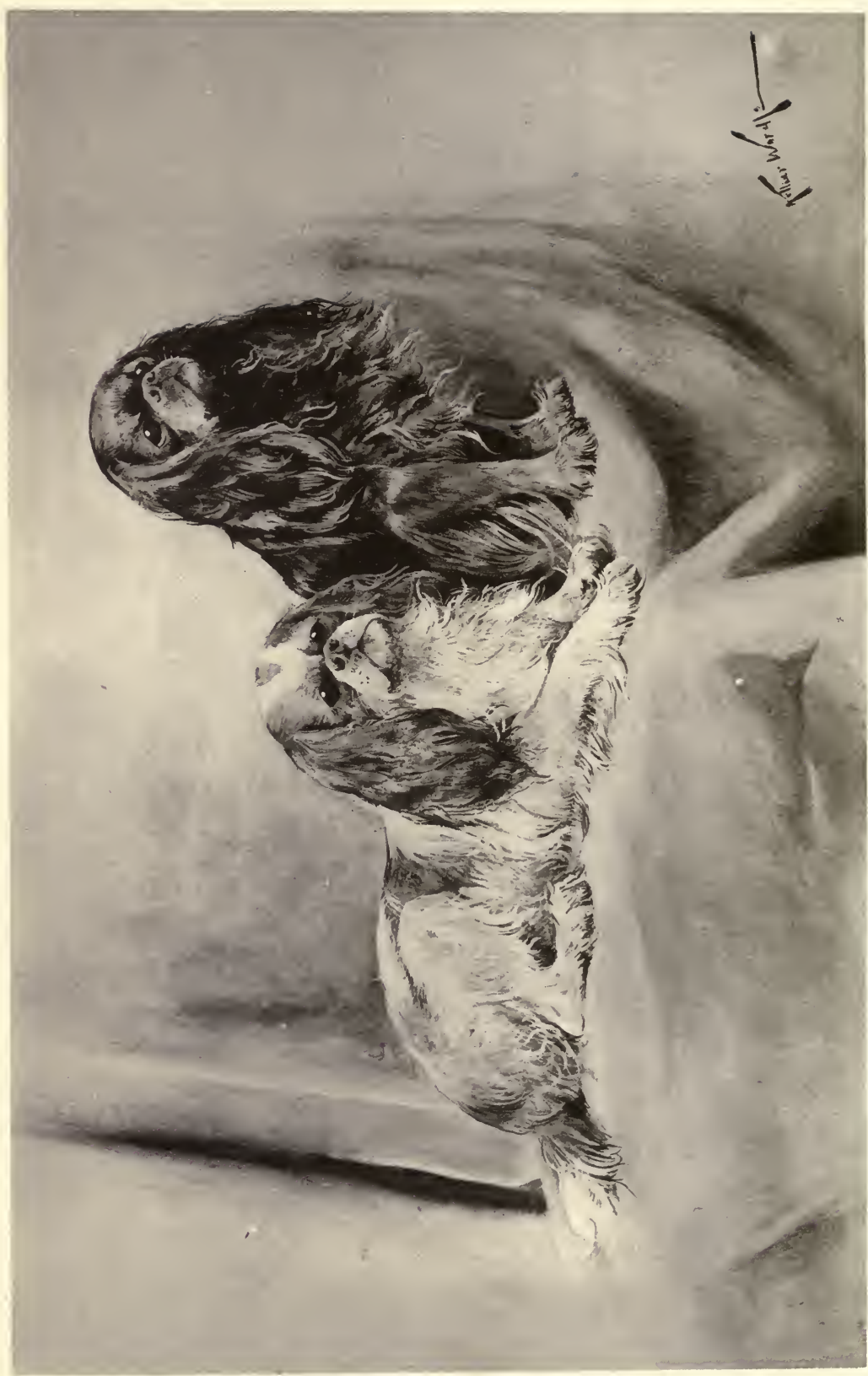




\section{CHAPTER XII.}

\section{ENGLISH TOY SPANIELS.}

NotwithstANDING recent introductions and popularisations of other canine pets, the toy spaniels appear to well hold their own in favouritism; one even fancies they are increasing in numbers, as they certainly are in quality. The original toy spaniels were black, tan, and white in colour; and orange or red and white, the former known as the King Charles, and later the latter as Blenheims. The King Charles were called after the second monarch of that name, who had so great a partiality and fondness for such creatures; and the Blenheims obtained their designation from the family seat of the Dukes of Marlborough, where at one time they were bred to perfection and kept with great care.

However, I imagine that long before the restoration of the Stuarts ( 1660 ), toy spaniels were general favourites with the aristocracy. A story is told that James II., on one occasion fleeing from a sinking ship, suddenly discovered that some favourite 
spaniels had been left behind, for which he would have the boat return, though previously he would not consent to put back to rescue his sailors, some of whom were drowned. One could scarcely believe even a monarch of the stamp of James II., guilty of so cruel and inhuman an action. But toy spaniels have not been fortunate in their connection with Royalty, for Mary Queen of Scots' favourite dog was a little black and tan spaniel, and it was found almost heartbroken, curled up in her royal mistress's gown a short time after her melancholy death at the axe of the headsman. About that time and a little later the toy spaniel became fashionable because he was a royal favourite, docile in disposition, and intelligent withal. Towards the close of the sixteenth century Dr. Caius alludes to him as "the Spaniell gentle, otherwise called the Comforter," but does not say much in his favour. He, however, alludes to such lap or toy dogs as "good to assuage the sickness of the stomach," being applied thereto as a preservative plaster, and as being likewise useful when borne in the bosom to keep in "moderate heat diseased and weak persons." Caius follows with a lot of other rubbish, but in his day the little dogs were pampered and petted much as they are now, and, no doubt because they afforded pleasure to their fair mistresses, who kissed and fondled 
them, obtained the name of Comforters; moreover, a vulgar superstition prevailed that if these little dogs were carried about the person of anyone suffering from disease, the disorder became transferred from the individual to the $\mathrm{dog}$, which usually died in consequence!

Some writers have said that the King Charles spaniel was originally brown and white in colour, but I have not been able to find anything to establish the truthfulness of such a statement; still I have no doubt that the original toy spaniel was much more like a little cocker spaniel than it is at present, and in addition to being used as a "comforter," was occasionally trained to hunt the coverts, beating out the pheasants and woodcocks, stirring up the hares and the rabbits just as the rustic biped with the long stick does at the present day.

Writers on canine matters at the early part of this century have little to tell about the King Charles and the Blenheim spaniels, excepting as to their value and sagacity. Sir William Jardine, as late as I 843, in his "Naturalist's Library," says of the King Charles that it is "a beautiful breed, in general black and white, and presumed to be the parent of the cocker;" but in I 820 John Scott wrote in the "Sportsman's Repository" that "the very delicate and small carpet spaniels have excellent noses and 
will hunt truly and pleasantly, but are neither fit for a long day or for a thorny covert. The "Sportsman's Cabinet" (1803) has little more to give about the King Charles spaniel, but mentions one that in 1792 belonged to a gentleman, in De Vere-street, Clare Market. This gentleman went with his family to Drury Lane theatre, about 5.30 in the afternoon, leaving the little dog locked up in the dining-room. At eight o'clock the door was opened, the dog escaped, found its way to the theatre, and although the house was crowded at the time, ferreted out its master, who was sitting in the centre of the pit. I am afraid none of our modern toy spaniels could perform such a feat as this.

The Dukes of Norfolk at one time had an exceptional strain of spaniels, which were valued highly, so much so that when a friend of one of the dukes asked as a favour for a puppy, his Grace haughtily replied, "Which of my estates would you like, sir?" Indeed, of this Howard, who bore no good name, it was said he valued these "trumpery little dogs more than he did his tenants, and, rather than present any of them with a puppy, either destroyed those for which he had not room, or fed his hawks with them."

Richardson, in a little handbook about dogs which he wrote in 1845 , says that "in London the King 
Charles and Blenheims are bred with great care and to the highest perfection. The Blenheim is frequently crossed with the Charles, so that the variety of colour, on which the difference in nomenclature depends, often appears in the same litter." After writing a lot of nonsense as to this cross, Richardson goes on to say that "Several 'Spaniel Clubs' have been formed to promote the careful breeding of these dogs, and of some of these His Royal Highness Prince Albert is patron, both Her Majesty and the Prince being enthusiastic admirers of these beautiful little creatures. His Royal Highness has, at no sparing outlay, erected a superb kennel for them at Windsor."

"The members of these spaniel clubs subscribe a small sum each, and with the amount contributed a handsome collar of silver, with gold entablature, is purchased; a particular day is then named, and judges are appointed, when each member brings to the club-room a dog of his own rearing, and that dog adjudged to possess the greatest number of good points attains the collar as a prize. King Charles and Blenheims have been known in London to fetch the price from I 50 to 200 guineas."

The above extracts are particularly interesting, as they give a clue to the early inter-breeding of two breeds from which we now obtain two other 
varieties, and the reference to the early establishment of dog clubs is likewise useful. Possibly some of the handsome collars won at these early club shows are still to be found, and I am certain they would compare more than favourably with the valueless silver medals some of the modern champions have to be contented with, as provided by show committees, although our popular Toy Spaniel Club appears to be unusually liberal in the prizes it provides for its own members.

No doubt from continual in-breeding, the peculiarly short faces and round skulls so much admired in the modern type of toy spaniel are procured, and not from any cross with the still shorter faced Japanese spaniel, which has been with us for a considerable number of years, nor with the pug dog, as has been suggested in some quarters. So far as I can make out there are not the remotest grounds for such statements. Our toy spaniel has been bred within its own variety, and possesses attributes distinct from those of the pug and of any other strain, with which an out cross would no doubt have interfered.

As I have said, the present King Charles spaniel must be black and tan, deep in black, and rich in tan, and the Blenheim is an orange and white marked dog, which ought to have an evenly coloured face, with a white blaze up the centre, widening 
towards the top of the skull, upon which should be an orange spot or mark called the "lozenge" or "spot." Several of our modern Blenheims are without this spot, but it is an old fancy, difficult to produce, and, although not of the slightest use, I do not care about seeing Blenheims devoid of it-a beauty mark, in fact.

One recent writer, alluding to the Blenheim spaniel, says: "Strange as it may seem to those who only know the Blenheim spaniel as the tiny lap dog with its retroussé nose, goggle eyes, and abnormally prominent brows, which properties are so admired by their lady owners, that animal was originally a sporting $\mathrm{dog}$, and I have reason to believe that there is a family connection, of remote period, between the Blenheim and the old fashioned liver and white spaniels that are to be found in the eastern counties. I am borne out in this opinion by the fact that, hung over the mantelpiece in the library at Elsenham Hall, the seat of Sir Walter Gilbey, is a portrait of one of the late Duke of Marlborough's spaniels, painted by Stubbs. This dog is represented to be curly-coated, with a long nose, and probably weighed upwards of 3 olb. This was no doubt the type of Blenheim spaniel that was known as a sporting dog, and has now been entirely lost sight of." However, such Blenheims as have 
recently been at Woodstock are pretty much the toys now admired, though by no means first-rate specimens from the modern point of view. The Duchess of Marlborough sent four to the Birmingham show in 1882 , but they were larger than the winners, and neither so short in face or round in the skull as they. Still, these Marlborough Blenheims were active, well formed little dogs, the biggest certainly not less than fourteen pounds weight.

A word or two may not be out of place here as to the earlier open dog shows, such as took place in London at Ashburnham Hall, Chelsea, and elsewhere, in the sixties. Divisions for King Charles and Blenheims were provided at all of them, and the former were usually well filled, the Blenheims not being so numerous. The King Charles were for the most part divided according to size, sometimes for dogs and bitches over $7 \mathrm{lb}$. weight, and for such under $7 \mathrm{lb}$. Then the division was for King Charles not exceeding $\mathrm{r} 2 \mathrm{lb}$. and under $7 \mathrm{lb}$., and in all cases the classes for the little dogs were best filled, there being as a rule approaching twenty entries or more. For the most part these divisions were supported by the London fancy already alluded to, and the best specimens came from Mr. Garwood, Mr. McDonald, Mr. W. Tupper, Mr. R. Mandeville, and Mr. J. W. Guppy. 



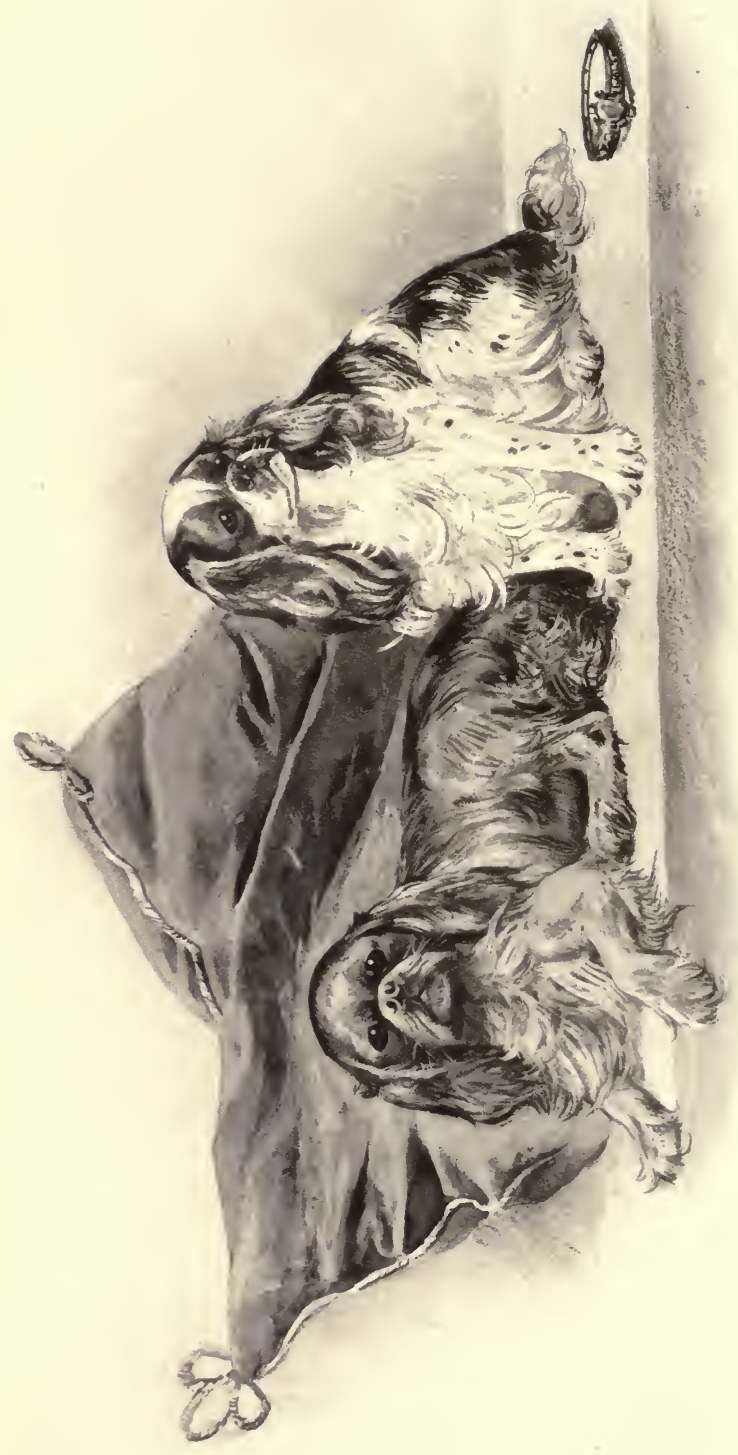


Of late years, in addition to the above two varieties, there have been classified the Prince Charles, which are black, tan, and white, and the Rubies, which are entirely red. Although at the present time these are rarer than the original strains, no doubt in a few years they will be equally popular. As a fact, the tri-colours are older than either the black and tans or the orange and whites; but it is only since the establishment of the Toy Spaniel Club in 1885 that they have obtained the distinguishing name of Prince Charles. Still, Landseer had immortalised them on his canvases long before, and his "Cavalier's Pets" and the "Lady and Spaniels" convey an excellent idea of the dog of which I write. The reds are the rarest and choicest of all the varieties, and although specimens were occasionally cropping up in litters of black and tans, such were not valued by the fancier, and attracted little attention. However, two or three particularly choice specimens were exhibited, and again the Toy Spaniel Club came to the rescue, named them aptly, and obtained them inclusion in the "Kennel Club Stud Book," where they were first classified in 1892 . Long before then, special prizes had been given for both tri-colours and Rubies, and at the Kennel Club Show held at the Crystal Palace in 1886 , several nice specimens of both varieties were shown by 
Mr. R. T. Linton, Mrs. Beavan, and Mrs. H. E. Jenkins. In November, the year previous, the first exhibition of the Toy Spaniel Club took place at the Westminster Aquarium, where there were eighty-four entries, and classes for King Charles, Blenheims, Prince Charles, Rubies, and "Toy Spaniels," were included in the schedule. The latter was for specimens not more than $7 \mathrm{lb}$. in weight, and the first prize was won by the red Ruby Princess, second by Mr. Lindsay Hogg's Japanese Ching Mhow.

As all these English toy spaniels are made so much on the same lines, and, in a certain degree, inter-bred with each other, it is not my intention to separate them under different heads any more than I have already done. I may remark that of the four varieties the Blenheim appears to be the most active; some I have known recently were not at all adverse to having a scamper after a rabbit, and no doubt had such been brought up in the country would have taken as kindly to the gun and the covert as a terrier or a cocker. Mr. W. C. Bennett, of Dublin, the solicitor to the Irish Canine Society, tells me that Mrs. Bennett has a Blenheim which is quite useful amongst the rabbits.

In my early days there were at least two persons in the north of England who kept King Charles spaniels, black and tans, with shortish faces and with 
as much coat and feather as the winners of to-day. All these dogs hunted by the water's edge, and would kill rats fairly well; but at the same period, and that would be thirty-five years ago, an old lady of my acquaintance had a couple of black and tan spaniels as fat and wheezy and incapable of exertion as the most distorted specimens of modern times. Of course this difference was brought about through the rearing and general surroundings.

As to the breeding and inter-breeding of the varieties there appears to be some difference of ideas, but none can be higher or more valued than the opinion of Mrs. Forder, of Southsea, one of the oldest breeders, and of Mr. Hugh Collis, of Rusham, honorary secretary to the Toy Spaniel Club, who have kindly contributed the following information.

They say that the Rubies are not a distinct variety, but in the first instance specimens came from the ordinary King Charles. Then it was sought to perpetuate or improve them by crossing with the Blenheim, but this proved a failure, as when Ruby puppies were born they had more or less white about them, and at one period it was actually impossible to get a Ruby spaniel without white, especially on the forehead or chest. By altogether leaving the Blenheim alone and keeping 
up the crossing with the King Charles the white disappeared, and at the present time there are sufficient Ruby dogs and Ruby bitches to breed from Ruby parents on both sides-so long as neither parent has Blenheim blood in its veins. Thus easily has this choice and handsome variety become perpetuated.

The tri-colours have always been, but by continual in-breeding with the darker coloured black and tans the latter are usually born free from white, although many of the best specimens even now have a few white hairs sprinkled up and down the coat and on the chest. Mrs. Forder is of my opinion, that the short noses are the result of in-breeding, which by that process, like any other deformity, can be accentuated.

Blenheims and tri-colours are sometimes bred together, with a result that you obtain the two varieties from the one litter; but when the black and tan and the Blenheim are crossed the most probable result is not the two varieties, but King Charles with white on them in the shape of a patch on the breast, on the forehead, or on the feet. There is no doubt that at the present time, with the material at command, there is not the slightest reason to make any crosses between the varieties; all are sufficiently distinct and representative, thus by freedom from 
breeding between relatives, and by judicious mating, there is no reason why the toy spaniels in their four varieties should not increase, multiply, and improve.

Within the past two or three years the abnormally short nose and the protruding, lolling tongue have certainly not been encouraged, and anyone attending the periodical exhibitions arranged by the Toy Spaniel Club cannot fail to be charmed with the pretty dogs that are there benched. These lovely specimens are not always from the homes of the noble and the wealthy, for in the. East End of London, where the labourer dwells, many of our best toy spaniels have been produced. Such little dogs are well adapted for cottage homes, as they take up less room than the bigger terrier, and are kept in good health with less exercise. Our English toy spaniels have for generations been favourites with the working man fancier, and his wife will attend to their comforts when she has put the children to bed. On the Saturday night, when his work is over for the week, this working man has a show of his own at his favourite "public round the corner," where, on the parlour table, his little beauties are placed to compete against those of his neighbours. The prize is generally a useful article of small value, given either by the landlord or by a friend. At such shows as these the choicest toy 
spaniels originally appear, and a good "stock" Blenheim or King Charles will bring in quite a little income to his owner. These working men often enough refuse $£^{20}$ and $£ 30$ apiece for their favourites, and it is indeed a moderate specimen that will not bring more than a five pound note.

I believe to the working classes of the East End we are indebted for the present excellence and popularity of the toy spaniels. Few are bred of any note whatever either at Blenheim Palace or in the neighbourhood of Marlborough. The Dukes of Norfolk have not taken any interest in them for a generation or two, and they are no longer favourites in the royal home at Windsor. Still, the breed survives, and under the fostering care of the specialist club will no doubt continue to improve. At their shows now, over a hundred specimens may be exhibited, and if such do not bring sums so exorbitant as the more fashionable collie and fox terrier, not long ago $£ 80$ was given for the King Charles Spaniel Laureate, and I know one or two Blenheims which are worth quite as much-Mr. Garrod's May Queen II., for instance.

Retracing our steps a few years, we find in I87 I Mr. C. Dawson's Frisky, Mrs. Lee's Jumbo, and Mr. Garwood's Hyllus, all animals of high stamp, and three years later Mr. Forder brought out a King 
Charles called Young Jumbo, which beat all before him for a time. Mr. Buggs succeeded not long after with Alexander the Great, then came Bend Or, Bend Or II., and Mrs. Forder's Jumbo, all of which attained to the dignity of champions. The following came later, and take us up to the present date, $\mathrm{Mr}$. Arnold's Grace Darling; Mrs. Graves' Little Gem, Golden Ben, and Sunbeam; Mr. Yates' Minerva; Mrs. W. H. B. Warner's Queen of the Toys and Laureate; Mr. R. Spencer's Olivette; Mrs. Collis' Donovan; and Mrs. Pestell's Paymaster.

The best Blenheims are Duke of Bow; Mrs. Jenkins' Bowsie and Flossie; Mr. Collis' Pompey and Ermine; Mr. Garrod's Excelsior and May Queen II.; Mrs. Blamey's King Stormy of Homerton; Mrs. Graves' Tiny Tots ; and Mrs. Forder's Haidee. In addition to the above, which have taken the leading prizes of late, from Mrs. Leeke's Sweet May Blossom I. and II. and her Lola, which run back as direct descendants from the Duke of Bow, have been produced many of the best Blenheims of the present day. Nor must Mr. J. W. Berrie's (afterwards Mrs. Booth's) The Earl, and Mr. J. H. Dawes' Prince, and Charlie be forgotten.

The most successful tri-colours or Prince Charles up to date are Mrs. Jenkins' Prince of Teddington, Day Dream, Mozart, and Zingra II. ; Mrs. Collis' 
Scamp; Mrs. Graves' Mother Bunch; and Miss Young's Lady Vivian. Before tri-colours were called Prince Charles, Miss Violet Cameron showed successfully a pretty little dog called Conrad.

The Rubies are yet in few hands, but several particularly choice specimens have appeared on the benches lately, and I rather fancy that of all the toy spaniels my admiration has been mostly extended to Mr. S. J. Thompson's exquisite Ruby Princess, and to Mr Garrod's equally choice Blenheim, May Queen II., neither of which would scale $7 \mathrm{lb}$. weight, and are almost perfect in other respects. Mrs. Jenkins and Mrs. Woodgate own the best strains of the Rubies, and the former's Ruby Prince and Golden Phiz, and the latter's Jasper, England's Best, and Carbuncle, with Mr. Knight's Turret Queen, are examples of a lovely variety of dog which anyone must feel proud in owning.

Many persons have decried these pretty toy spaniels of ours because it is said they are dirty, snappish, strong smelling, and generally disagreeable as house dogs and ladies' pets. This is not at all the case, and when there is any foulness from the breath or skin such arises through ill-health and neglect. The Blenheim, as already hinted, is the most sprightly and lively of the breed of toy spaniels, sweet in disposition, sensible, cleanly, and an admir- 
able follower in the crowded streets when properly trained. There is no guile about him, and if he prefers to pay attention to all the movements of his fair mistress, and is ever ready to be fondled in her lap, he never forgets to come to a stranger and give him welcome, and no doubt expects a word of praise in return. He is not so liable to become fat and podgy as the King Charles, and in most respects the Ruby Spaniel takes after the Blenheim in disposition and character.

The black and tan and the tri-colour are alike in general conduct and behaviour, and appear to be less dainty as to their food than are the other varieties, and so have a tendency to become obese. This they should not be allowed to do, as it interferes with the glossiness of their coats, and I am inclined to believe has a tendency to make the jackets become curlier and not so straight as would be the case under healthier surroundings. This tendency for the coat to lose its straightness with increasing age is one of the great drawbacks to the King Charles spaniel, and in this respect a modern fouryear-old dog is not to be compared with a puppy of twelve months or so. Some of these toy spaniels have a habit of lolling out their tongues, which is bad; others have indifferent sets of teeth, which is equally bad. Level mouths are the best, but in many 
instances breeding for the abnormally short noses appears to have produced undershot mouths, i.e., where the lower row of teeth protrudes in front of the upper row. The mouth of the toy spaniel should be as level and uniform as that of a terrier.

All toy spaniels require their toilet attending to, or the feather becomes matted, and the little creature loses the gloss on his coat. An ordinary hair brush and an ordinary comb will answer all purposes admirably, and if your little pet has these used on him pretty regularly once a day, and he is given a "tubbing" when he requires it, is not fed too highly, and is occasionally doctored with a gentle dose of magnesia, he will repay the trouble by being sleek and healthy, and as engaging a little companion as anyone need desire.

The following are the descriptions and points of the four English varieties as drawn up by the specialist club :

\section{Points of Toy Spanieis (English).}

"Head.-Should be well domed, and in good specimens is absolutely semi-globular, sometimes even extending beyond the half-circle, and absolutely projecting over the eyes, so as nearly to meet the up-turned nose.

"Eyes.-The eyes are set wide apart, with the 
eyelids square to the line of the face-not oblique or foxlike. The eyes themselves are large, so as to be generally considered black; their enormous pupils, which are absolutely of that colour, increasing the description. From their large size, there is almost a certain amount of weeping shown at the inner angles; this is owing to a defect in the lachrymal duct.

' Stop.-The 'stop,' or hollow between the eyes, is well marked, as in the bulldog, or even more so, some good specimens exhibiting a hollow deep enough to bury a small marble.

"Nose.-The nose must be short, and well turned up between the eyes, without any indication of artificial displacement afforded by a deviation to either side. The colour of the end should be black, and it should be both deep and wide, with open nostrils.

"Faw.-The lower jaw must be wide between its branches, leaving plenty of space for the tongue, and for the attachment of the lower lips, which should completely conceal the teeth. It should also be turned up or 'finished,' so as to allow of its meeting the end of the upper jaw, turned up in a similar way as above described.

"Ears.-The ears must be long, so as to approach the ground. In an average-sized dog they measure 2oin. from the tip to tip and some reach 2 in. or even a trifle more. They should be 
set low on the head, and be heavily feathered. In this respect the King Charles is expected to exceed the Blenheim, and his ears occasionally extend to 24 in.

"Size.-The most desirable size is from 7 lb. to Iolb.

"Shape.-In compactness of shape these spaniels almost rival the pug, but the length of coat adds greatly to the apparent bulk, as the body when the coat is wetted looks small in comparison with that dog. Still it ought to be decidedly ' cobby,' with strong stout legs, broad back, and wide chest. The symmetry of the toy spaniel is of importance, but it is seldom that there is any defect in this respect.

"Coat.-The coat should be long, silky, soft, and wavy, but not curly. In the Blenheim there should be a profuse mane, extending well down in the front of the chest. The feather should be well displayed on the ears and feet, where it is so long as to give the appearance of their being webbed. It is also carried well up the backs of the legs. In the King Charles the feather on the ears is very long and profuse, exceeding that of the Blenheim by an inch or more. The feather on the tail (which is cut to the length of about three and a half or four inches) should be silky, and from five to six inches in length, constituting a marked "flag" of a square shape, and not carried above the level of the back. 
"Colour. - The colour varies with the breed. The King Charles is a rich, glossy black and deep tan; tan spots over the eyes and on cheeks, and the usual markings on the legs are also required. The Ruby spaniel is a rich chesnut red. The presence of a few white hairs intermixed with the black on the chest of a King Charles spaniel, or intermixed with the red on the chest of a Ruby spaniel shall carry very great weight against a dog, but shall not in itself absolutely disqualify; but a white patch on the chest or white hairs on any other part of a King Charles or Ruby spaniel shall be a disqualification. The Blenheim must on no account be whole coloured, but should have a ground of pure pearly white, with bright rich chesnut or ruby-red markings, evenly distributed in large patches. The ears and cheeks should be red, with a blaze of white extending from the nose up to the forehead, and ending between the ears in a crescentive curve. In the centre of this blaze there should be a clear 'spot' of red, of the size of a sixpence. The tri-colour, or Charles the First Spaniel, should have the tan of the King Charles, with markings like the Blenheim in black instead of red on a pearly white ground. The ears and under the tail should also be lined with tan. The tri-colour has no 'spot,' that beauty being peculiarly the property of the Blenheim. 
"The only name by which the tri-colour, or black, white, and tan, in future shall be recognised is 'Prince Charles.'

"That in future the all red toy spaniel be known by the name of 'Ruby spaniel.' The colour of the nose to be black. The points of the 'Ruby' be the same as those of the 'King Charles,' differing only in colour."

\section{Scales of Points.}

King Charles, Prince Charles, and Ruby Spaniels.

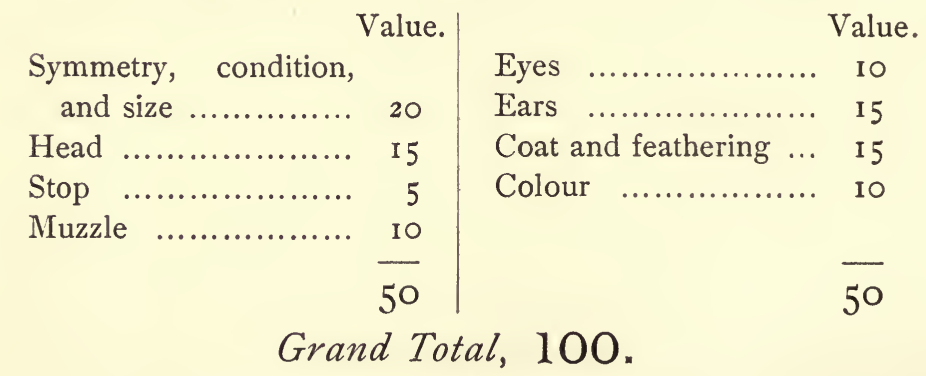

Blenheim.

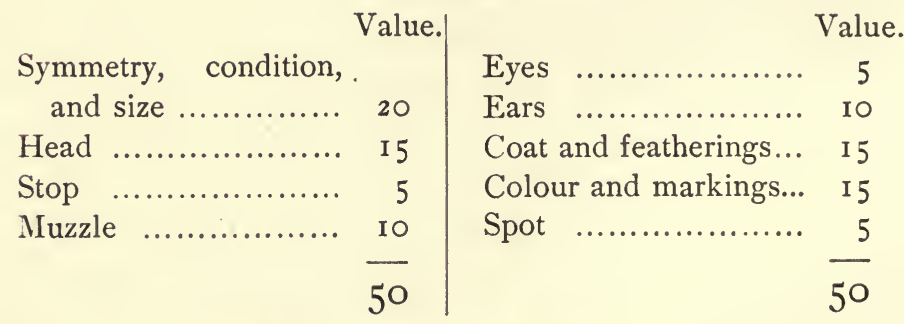

Grand Total, 100. 



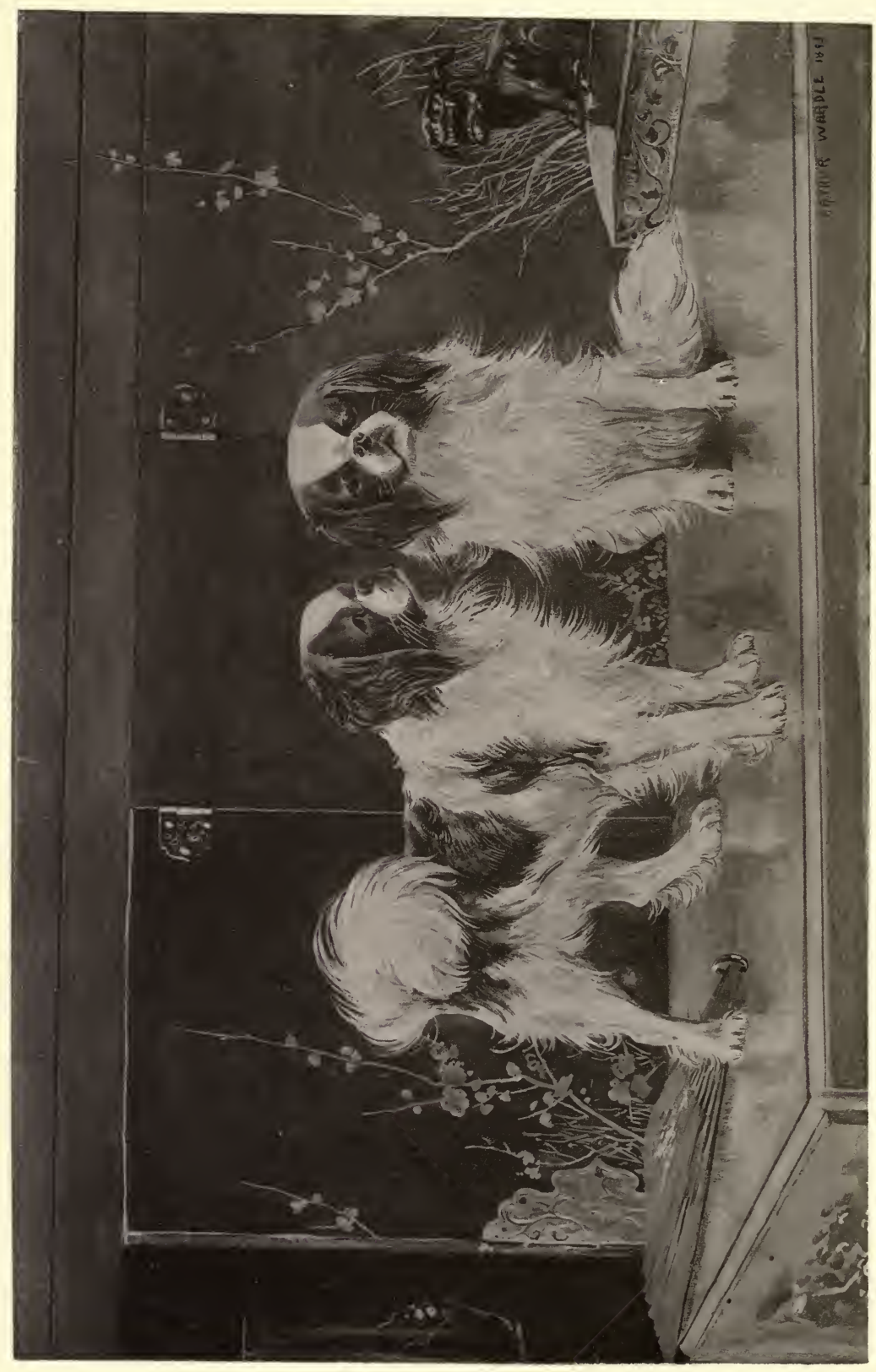




\section{CHAPTER XIII.}

THE JAPANESE SPANIEL.

IN some quarters an impression prevails that the Japanese spaniel is quite a modern introduction. This is, however, not so; and at one of our very earliest dog shows-that held in the Holborn Horse Repository in $1862-a$ class was provided for Japanese, which at that time were oftener called pugs than spaniels. There were then nine entries, and Mr. C. Keller, Camberwell, won first prize with a black and white dog called Caro.

The Japanese themselves claim great antiquity for these little dogs, going so far as to be rivals with the Maltese in that respect, and declaring that our own toy spaniels were originally produced from the Japanese. But, as I have had to say repeatedly, the origins of the varieties of the dog cannot be traced. We have them and so should be contented.

These little dogs are now called and identified as Japanese spaniels because they are supposed to 
have originally been brought from Japan. From what I have been told, and from what I have read, I believe them to be equally indigenous to the northern and other parts of China. In the Field over twenty years ago there was an excellent article on the dogs of China, in which the writer states that there is the "Pekin pug, remarkable for its diminutive size, sometimes so small as to be carried in the sleeves of a Chinese coat. Hence they are called sleeve dogs. Some resemble the old-fashioned short-bow-legged pugs, which may have been originally introduced into Europe from China by the Portuguese, and hence called Portuguese or Spanish pugs. These dogs are generally smooth skinned. There are other kinds, resembling Scotch Skye terriers, which might, in some exaggerated instances, be considered equally handsome in their extreme ugliness, in having their faces concealed by long hair, and a line of division running along the back, the hair on each side reaching to the ground. All these kinds are remarkable for the shortness of their nose, giving rise to the supposition that it was the result of mechanical interference with the proper growth of the head, as in the case of the artificially produced distortion of the feet of the Chinese women, but such is not the case, as all who have seen the little puppies of the species can testify. . . . 
These small dogs were originally derived from Corea, and are continually imported from that country into China, where, especially in the north, they are much valued, where they are to be found in the houses of the wealthy."

The above, as being written by an authority on Chinese dogs, I think well worth reproducing, but whether admirers of the Japanese dogs will recognise much resemblance to their favourites in the dogs described, is a matter for them to determine. In I 870 a black and white Japanese spaniel, such as we have now, was entered at a Crystal Palace dog show by Mr. P. Gordon. It was called a Mandarin pug, and said to be one of the four taken at the sacking of the Summer Palace at Pekin. This little dog was about twelve years old when shown in England.

In their native country the "Japs" are called "sleeve dogs," because it is, or was, the fashion for the Japanese swell of the period to carry his little toy dog about with him hidden in one of the sleeves of his flowing garment. Thus the smaller the dogs the better, and specimens not more than three pounds weight are cherished exceedingly. It is said that to keep the dogs as minute as possible, it is customary when young to give them a liquor called "saki," which retards their growth. Such 
an idea is quite as fallacious as is the belief at one time common with us, that our diminutive toys were made so by potions of gin given at stated periods. Elsewhere I have alluded to a similar system which was said to be carried out with the Maltese dogs.

There appears to be a little difference of opinion here as to what size a Japanese spaniel ought to be, and I consider that a specimen $6 \mathrm{lb}$. weight or so is quite small enough for anything. When smaller dogs are produced they are delicate and sickly, uncertain breeders, and for these reasons are not desirable, and those judges who would give a prize to a very diminutive specimen, which, so far as locomotion is concerned, is as a dwarf at a penny show compared with a full-grown man, are certainly not going the right way towards perpetuating the breed in this country. Still, where one of the most diminutive creatures is as perfect and active as the larger specimens, the latter must on the occasion take, as it were, a back seat.

On the subject of size, Mr. C. F. Grindrod, of Malvern, wrote to a weekly paper not long ago :-

"Japanese spaniels are of almost any size from even under $4 \mathrm{lb}$. weight to over $20 \mathrm{lb}$. Specimens are fairly healthy from 6lb. or 7 lb., bur usually much more so from $8 \mathrm{lb}$. to I $2 \mathrm{lb}$. Where, however, the weight is reduced to $4 \mathrm{lb}$., of which we have had 
several examples at late shows, it means the product of breeder's tricks, which it is wrong to encourage.

"These tiny specimens, again, have not got the points of the larger ones, though they are undeniably very pretty-also undeniably useless, except for the shows. No possessor of a female specimen of these attenuated Toys dare run the risk of breeding from it-a sufficient proof of nature gone wrong.

"Apart from this, I maintain that the true charms of the species, the admitted points, are lost in these tiny examples. To take one point alone, no one ever saw a grand head in a very small-bred Jap; and this, according to the Toy Spaniel Club's description (from which, by the way, at least as regards colour, a native of Japan would hardly recognise his own breed), ought to rank first of all, yet counts very little with most judges.

"To the only defensive argument raised by the ladies for diminutive Japs, that Toys should be as small as possible, I reply that health should count before a fad, and I also ask, 'How about King and Prince Charles, some of the best of which have weighed from I $2 \mathrm{lb}$. to $20 \mathrm{lb}$, , and which are probably own cousins to the Japs?'

"One cannot dictate exact weights in any breed, 
but my own belief is that Japanese spaniels are best all round at about 81b., and that if you breed them much under this weight you sacrifice both strength and beauty to a foolish and even cruel fad. That the breed is not naturally so small is proved by the fact that if you leave nature alone you cannot produce diminutive specimens, and I challenge anyone to dispute this assertion. I have seen some very small ones bred, and they have either died young, or been 'effeminate' indeed.

"I write this from no personal interest, for I possess a prize Jap of 6lb. weight, and another prize one of I 2 lb., but in the hope-not a very great hope, since the ladies are against me-of saving what I regard as the most beautiful breed of small dogs in the world from the fatal danger of attenuation.

"May I add that the dogs, though called, and doubtless rightly called, spaniels, are not a bit like typical spaniels in their nature, being the liveliest, sauciest, almost maddest-spirited little dogs in creation; but, then, to be this they must not be dwarfed beyond the limit Nature demands for healthy organism."

There is a good deal of common sense in the above extract, and coming from a great authority on the variety, is the reason of its reproduction here, 
and especially as there is at the present time a slight run in favour of the Japanese spaniel.

Our big shows now provide classes for them, although, after the exhibition held in $186_{3}$, already alluded to, such was not done for a considerable period. In due course, we shall doubtless see the variety included under its own head in the Kennel Club's Stud Book.

Although the usual colour of the "Jap" is black and white, fawn or yellow and white and wholly fawns or yellows are sometimes seen, specimens of the latter colour being, however, extremely rare. All varieties, no doubt, come from the same parents, and Mr. Grindrod writes me that he has just had two litters from black and white parents, good specimens and prize winners, and three out of the ten puppies born are lemon and white in colour, the remainder being beautifully marked black and white; Mr. Grindrod further remarks that the lemon and white when mated together, include black and white in their progeny.

The same authority says: "The Japanese spaniels are a very distinct breed. In character they are intensely affectionate, and do not readily take to strangers. They are likewise noted for their cleanly habits; some of them clean their faces in the same manner as cats do, and, besides, they are a little 
feline in their peculiar ways and nimble action, in cases eating like cats in a dainty, slow, pecking manner.

"As to type, there are many varieties of this breed in Japan, some large, some small, some shorthaired, some long-haired, others thick-legged, others very fine-legged. To describe a typical specimen, I should say from 6lb. to $12 \mathrm{lb}$. in weight; black and white in colour, black ears. the colour nearly or quite meeting across the back of the skull, with a broad, white blaze on the forehead; in nearly all specimens the eyes are broadly edged with black, which is continued from the ears, leaving the muzzle white; body either richly broken black and white, or white pointing into black behind, or saddle marked; white tail like an ostrich feather, curling tight over the back; legs white, well feathered, and feet well tufted; ears short, being well forward and long feathered; face very short, with deep stop behind the nose; eyes large, lustrous dark-brown, rather prominent; skull broad and high vaulted-in bitches more flatly arched than in dogs; body square and cobby-shaped, not too long; legs shortish, fine in bone; the feet delicately pointed and very flexible, with deeply divided toes, in fact, the feet are like large pads, and this is a leading characteristic in the breed; the coat should be very long, silky in texture, 
and not curly. In the best specimens the jaws are square, the head massive, with overhanging forehead; but this is only to be seen in the larger dogs, those of $\mathrm{Iolb}$. or $\mathrm{I} 2 \mathrm{lb}$. weight. In very tiny specimens the face is more pointed and foxlike."

Such is Mr. Grindrod's opinion of what a Japanese spaniel should be in size, colour, \&c.; but I consider that fawns marked in a similar manner are equally as good as the black and whites, and the whole or selfcoloured fawns equal, if not superior, to either.

Mrs. W. H. B. Warner, Northallerton; Mrs. Grindrod; Miss V. Thomas, Ealing Dean; Mr. L. Edwards, Brixton; and Mr. Lindsay Hogg, London, have from time to time had good specimens of this variety, whilst some years ago, Mr. T. Marples, of Stockport, showed with great success a Japanese called Ming Seng, which weighed glb.

The following are the points and description of the variety as issued by the Toy Spaniel Club :

Points of Japanese Toy Spaniels.

"Head and Neck.-Should be large for size of animal, very broad, and with slightly rounded skull. The neck should be short and moderately thick.

"Eyes.-The eyes should be large, dark, lustrous, rather prominent, and set wide apart.

"Muzzle.-Must be strong and wide, very short 
from eyes to nose. The upper jaw should look slightly turned up between the eyes; the lower jaw should be also turned up or 'finished' so as to meet it; but should the lower jaw be slightly underhung it is not a blemish, provided the teeth are not shown in consequence.

"Nose.-Very short in the muzzle part, the end or nose proper should be wide with open nostrils, and must be the colour of the dog's marking, i.e., black in black marked dogs, and red or deep flesh colour in red or lemon marked dogs.

"Ears.-Should be small and V-shaped, nicely feathered, set wide apart, and high on the head, and carried slightly forward.

"Body.-The body should be very compact and squarely built, with a short back, rather wide chest, and of generally 'cobby' shape, the body and legs should really go into a square, i.e., the length of the dog should be about its height. The dog should rival the pug dog in this, and also in its carriage, which should be particularly smart.

"Liegs.-The bones of the legs should be small, giving them a slender appearance, and they should be well feathered.

"Feet.-These should be small, and shaped somewhat like a cat's, i.e., the dog stands up on its toes somewhat. If feathered, the tufts should never 
increase the width of the foot but only its length a trifle.

"Tail.-This must be carried in a tight curl over the back; it should be profusely feathered, so as to give the appearance of a beautiful 'plume' on the animal's back.

"Coat.-The coat ought to be profuse, long, straight, rather silky; it should be absolutely free from wave or curl, and not lie too flat, but have a tendency to stand out, especially at the neck, so as to give a thick mane or ruff, which with profuse feathering on thighs and tail gives a very showy appearance.

"Colour.-These dogs can be whole coloured in either of three colours, viz., black, red, or white, but they are preferable parti-coloured, either black and white, red and white, or lemon and white. The most ordinary and favourite colour is, however, red and white, lemon and white, black and white, in the order named. In all parti-coloured specimens the ground colour should be a pure pearly white, and the other colour be in large evenly distributed patches over the body and over the ears and cheeks. Sometimes the markings are those of a Blenheim spaniel, including the spot; but more colour on head and large saddle on back with coloured tail is equally usual, as are several other distributions of 
colour, the Blenheim markings are, however, the most showy. All variations of markings are correct providing the colours remain distinct, well defined and distributed in fairly even proportions over the body.

"Size.-The size desirable is from $4 \mathrm{lb}$. to glb. weight, the smaller size are preferable if of good shape."

\section{Scale of Points.}

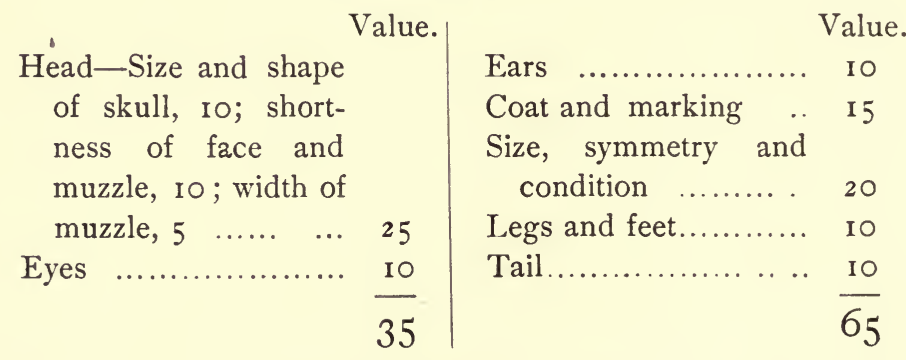

Grand Total, 100. 



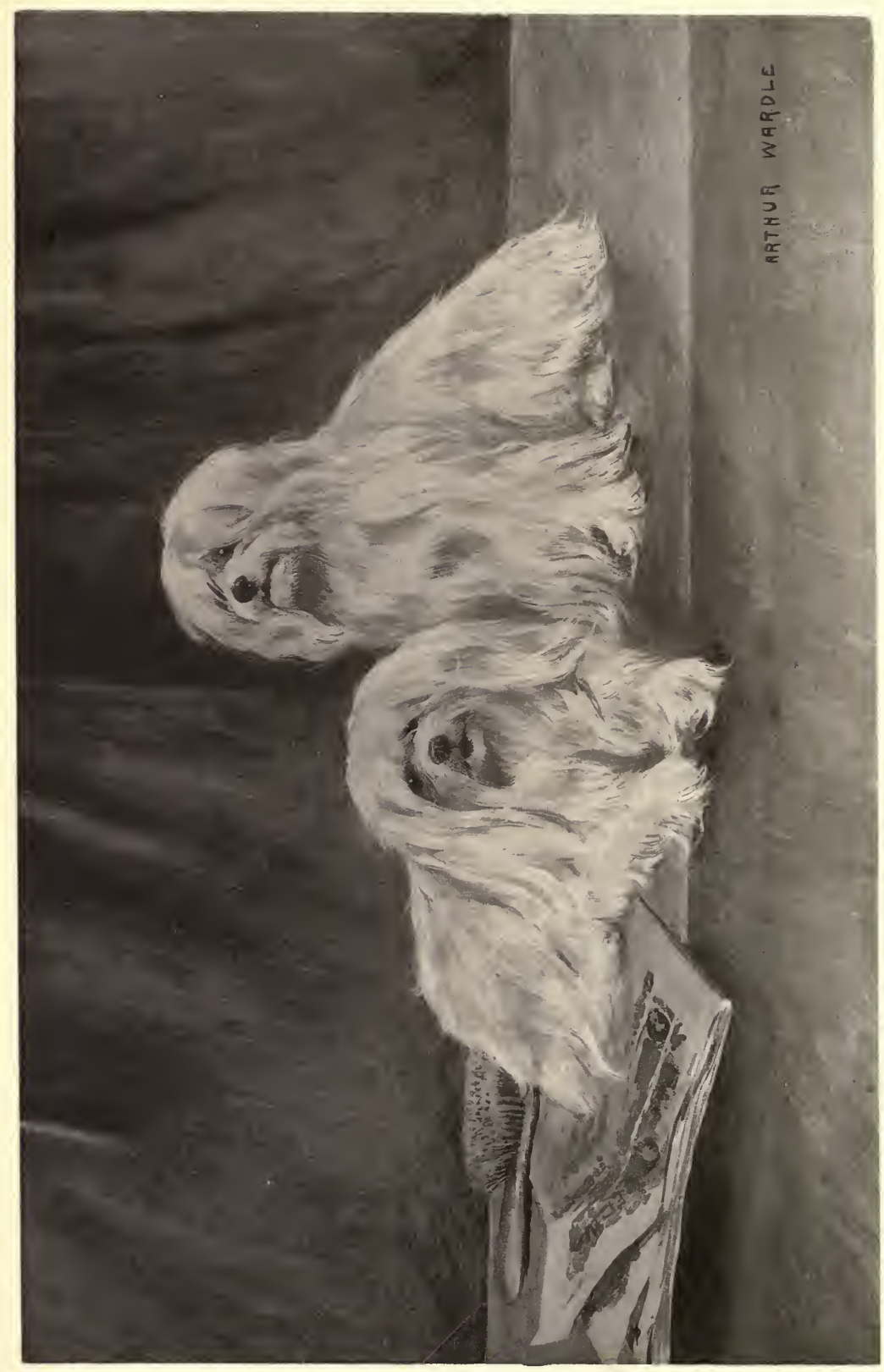




\section{CHAPTER XIV.}

\section{THE MALTESE.}

Sometimes this charming little dog is called a terrier, on other occasions a spaniel, whilst in many quarters it has been known as the Lion dog of Malta. Sir Edwin Landseer painted it as the latter about 1838 , from a specimen stated to be the last of the race. This picture does not appear to be very well known, but as representing a typical Maltese of the present day it must be noticed here. The Maltese "Lion dog" is reclining on a table, upon which a hound is resting its head, the latter no doubt introduced by the great artist to show the diminutiveness of the principal object in the picture, which it undoubtedly does most satisfactorily. The original painting was, I believe, the property of the late Duchess of Kent.

Whatever doubt there may be as to whether the Maltese dog is a terrier or a spaniel (I do not consider it either), there is no question whatever as to its being by far the oldest of our toy dogs, as it is 
the rarest at the present time, and, Landseer notwithstanding, the day of the last of the race has not yet been reached. Two thousand years ago and more the dainty creature was nestled in the laps of the ladies of Greece and Rome, where he was said to divide attention with the dandies and bucks of that day, or, as they were then called, "puppies," a name which still clings to them as occasion requires.

Many early writers have mentioned these little dogs of Malta. Aristotle did, and he died 322 B.C., whilst the elder Callimachus, who was almost his contemporary, likewise alludes to them, and has something to say as to hounds and dogs generally in his poem to Diana. No doubt those Canes Melitæi were pretty much identical with the long-haired, white little dog which is the Maltese of the present day, and that he was of an ancient race even then is evident from the fact that there appears to be some confusion as from whence he came. There are two islands bearing the name of Melita, from either of which this dog may have been originally introduced.

The one island was Melita in the Adriatic, near Dalmatia; the other Melita in the Mediterranean, near Sicily, and the Malta of to-day. Callimachus, already alluded to, and who was undoubtedly an authority on dogs in his day, says the little animal originally came from the Melita in the Adriatic, and 
the learned Bochart, in his "Hierozoicon," quotes him as likely to be right in his statement. Others have said the dog first came from Melita in the Mediterranean, which island is at the present time generally acknowledged, though I believe wrongly, to be the native country of the Maltese toy dog.

However, the most complete record of the early history of the Maltese $\operatorname{dog}$ is to be found in the Natural History of Ulysses Aldrovandus, who died in 1607. His great work, which was in Latin, was published after his death. He says there are two varieties of this Maltese $\mathrm{dog}$, one of which was comparatively short in its coat, the other long; and as he was unable to say which was correct, he gave us illustrations of each. Both are identical, excepting so far as coat is concerned, that with the longer jacket being pretty much the same $\operatorname{dog}$ as we find to-day. The second is the smaller of the two, and, although by no means short-coated, is not so long in the jacket as the other. Aldrovandus quotes pretty freely from other writers, especially as to the origin of this little dog, Blondus ascribing it to Spain, and Gesner to Lyons. However, we must be contented that it came from Malta. In the seventeenth century we are told the best colours were white and red (? fawn), but some were black and white. The smaller they were the better and more valuable they 
became, although they bore the reputation of being ferocious and ill-natured. The Italians sometimes called them botoli, because, though small, they were ferocious and bad-tempered, botolo being an old I talian word meaning a quarrelsome little cur, or a worthless, degenerate little dog.

The value of a good specimen of this animal was such that Aldrovandus says he had seen one sold for $£ 400$ ! 'This was, probably, at Bologna, during our Elizabethan period. But the value of money at that time and in that place is no criterion as to its value in English money at that date or now.

The same author also furnishes us with some interesting little pieces of information as to the breeding and rearing of these diminutive creatures, giving an insight into the arts of the dog fancier of that day, which appeared to be plied with as much care and skill as is the custom at the present time, the Kennel Club notwithstanding.

In the first place it is said that owing to the smallness of the best Maltese dogs, they could with difficulty be induced to breed, and when such was the case they were fed on hot foods. Then the bitches often died during pupping, and care was taken in breeding that only the very tiniest dogs were used to bigger animals of the opposite sex. A quaint idea was in vogue that when the bitch, in whelp, 
was allowed to sleep upon and have her bed of a sheep-skin or fleece of wool, the puppies were born with longer coats and manes more lion-like than would have been the case if the bitch's bed was of straw or shavings - filios jubatos instar leonis. Thus we have at once the origin of the name the "lion dog of Malta."

Some time after being born, no doubt when they were getting on to their legs, they were given as little exercise as possible, being kept in tin canisters or boxes in order to keep them small in size and as the fancier required them to be; the best specimens being said to be no bigger in body than a rat or a weasel. Then the dietary was carefully guarded, they eating little food, and that of a particular quality. The favourite diet was "liver or lights, dried and sprinkled with the pared fresh bark of the wild fig tree," the drying operation taking place in a warm room provided for the purpose. Queens, it was said, fed the dainty little creatures with the choicest cuts from the breasts of fowls, which were served out of golden vases.

Here is another choice little bit for our modern dog fanciers, for old writers say that when the Maltese puppies were born it was the custom to twist the "rostrum" (the upper nose) with the fingers "in 
order that they may seem more elegant in the sight of men." Surely after this operation-which, for anything we know to the contrary, may have been performed before the Christian era-who can say there is anything new under the sun; and the bulldog men who manipulate the noses and muzzles of their "beauties" are only following on the lines of their brother fanciers who preceded them in more barbarous times.

I think I have written enough to prove that the Maltese dog was a valued canine commodity and companion long before England was a great nation. Since she has become so, this dog, with others, has doubtless improved somewhat, though at the present time I should scarcely know where to place my hand on a perfect specimen. We must have them immaculately white, a fawn mark being a great blemish, and a black one, I fancy, has not been observed for a long time. Thirty years ago there were more of the variety to be found than is the case to-day; but if they were difficult to breed three hundred years since, unless special trouble had been taken to improve them in that respect - certainly not by confining them in boxes and feeding them on dried liver-which does not appear to have been the case, the wonder is the breed survives at all. 
The late Mr. Robert Mandeville, of London, about 1860 and later, had a very excellent strain of the variety, and so had Mr. W. Macdonald, also of London; then came the Hon. Mrs. Bligh Monk, of Reading; Lady Gifford, of Redhill ; and Mr. J. Jacobs, of Oxford, all of whom at one time or another owned the most perfect specimens that have been produced during the present generation. Mr. Mandeville's Fido and Lady Gifford's Hugh were particularly choice in their way, "white as driven snow, coat like floss silk, less than $5^{\text {lb. }}$ weight each, and with not a dark hair on their bodies." At the early shows the classes given to this variety were far better filled than is the case now when competition usually appears to be restricted to two or three animals. At the Holborn Show in London in 1862 there were twenty Maltese entered, there were forty-one in the same year at Islington, and two years later eighteen of the little dogs were present at Ashburnham Hall. Most of these entries were made by the London fancy, but W. Mandeville was usually at the top, as he continued to be for many years, even so recently as 1870 at the Crystal Palace, when the competition had dwindled to seven competitors, and it appears to have continued to slacken and become less ever since. 
Mr. J. W. Watts, of Birmingham, owns perhaps the best dogs of this race $\mathrm{I}$ at present know, in Prince Lily White and Flossie; but these dogs do not reach the perfection of such specimens as Hugh and Fido, already mentioned, their coats being neither so good in texture nor so perfectly white as the past champions of their race. Mr. Jacobs, of Headington Quarry, near Oxford, at times shows two or three very good specimens, some of which are of Mrs. Bligh Monk's strain.

The unpopularity of the Maltese dog must be ascribed to the difficulty in breeding him to perfection, and the trouble which follows to keep the coat in order. The latter requires brush and comb two or three times a day, washing not too often but just often enough, and their jackets are of such a length that it actually ruins them and spoils the dog if exercise is given in dirty weather, or if when out they get caught in a shower. They are just such dainty creatures as the indolent women of the Roman period would cherish and fondle, but are scarcely likely to be popularised in our more matter-of-fact days. They had the reputation of being ferocious and bad tempered. Now such cannot be said of them, though they are somewhat more inclined to be snappish with strangers than are other pet dogs. 
The general form, shape, and character of the Maltese dog may be obtained from the illustration preceding this chapter. In weight he should be not more than from, say, $7 \mathrm{lb}$., and about $5 \mathrm{lb}$. is preferable; colour, all white, with long silky hair, quite unlike that on any other dog, more of the consistency and appearance of "spun glass" than of anything else ; it must be straight, quite free from curl, and the length of hair on a perfectly coated specimen will certainly not be less than seven inches. The nose and eyes must be black. There is usually a redness of the hair under the eyes made so from the eyes watering; the less of this the better, but I am afraid it cannot wholly be avoided. The tail ought to be carried turned or doubled into the coat of the back, and not gaily erect like the rags at the end of a mopstick. The ears should be small and dropping, well clad with hair, and scarcely discernible on a good coated specimen. In disposition the dog should be sprightly; the mouth must be level and the teeth white. It is very seldom we now see a dog of this variety with a nose perfectly black, but if obtained it is most desirable; ears with pale fawn marks covering the whole or part, are likewise much too common, and should form a severe handicap to the dog bearing such a defect. 
I would place the numerical points of the Maltese dog as follows :-

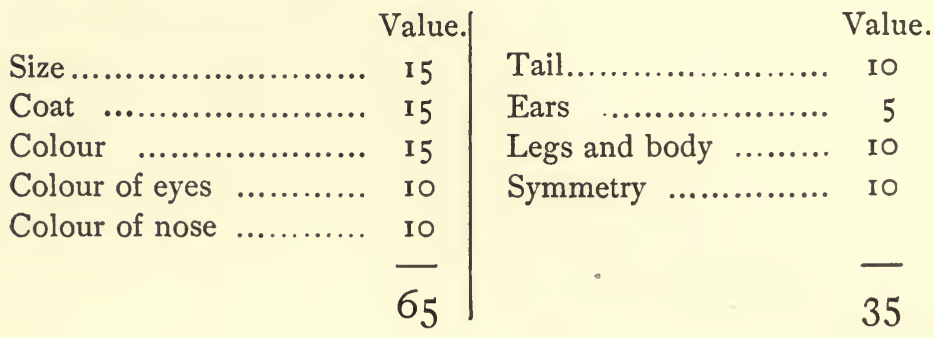

Grand Total, 100. 



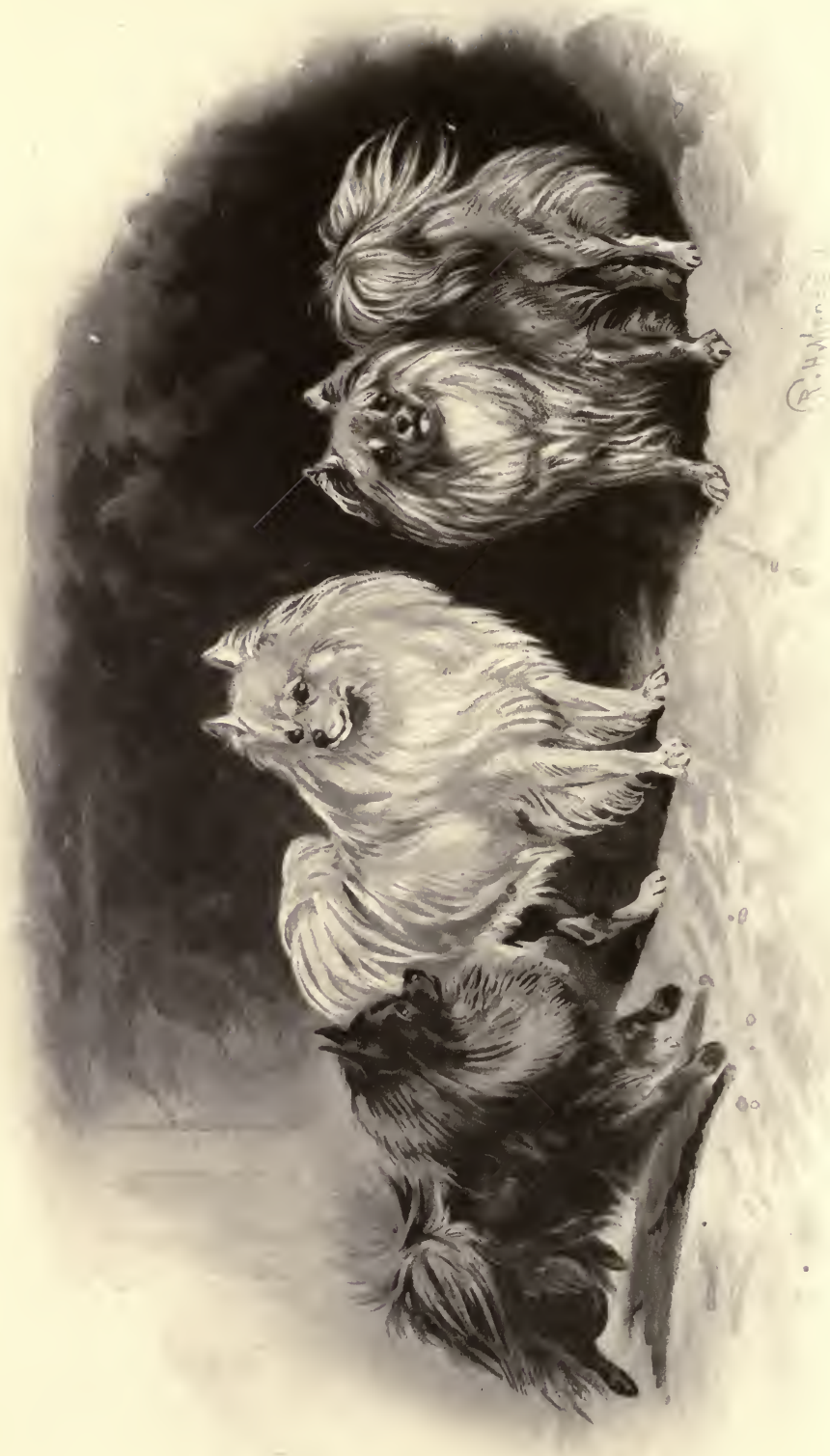




\section{CHAPTER XV. THE POMERANIAN.}

THIS dog has from time to time been known and recognised under many different names, as the Spitz, Loup-Loup, Pomeranian, Wolf dog, Fox dog, and may be by others. There is little doubt that he more nearly approaches in appearance, and in a certain shyness which occasionally prevails in some specimens, such semi-domestic animals as the dogs of the Arctic regions, including the Samoyedes and the smaller varieties of the Esquimaux, than any other of our European dogs. One of the Samoyedes owned by H.R.H. the Prince of Wales very much resembles a white Pomeranian excepting in coat, which on the first-named is comparatively short as compared with that of the other.

The Pomeranian, or Spitz dog, as it was until quite recently called, was no doubt originally brought from Pomerania, a country which lies on the shores of the Baltic Sea; when he first became acclimatised with us there is nothing to show; that he 
has been one of us for a great number of years there is no doubt whatever.

Amongst the earliest writers who have described the variety must be noticed the author of the "Sportsman's Cabinet" (1803), who gives the animal a bad character, as he does most other varieties of the canine race that are not used for sporting purposes. Assuredly the Pomeranian is not a sporting dog. The "Sportsman's Cabinet" says: "The dog so called in this country is but little more than I8in. or zoin. in height, and is distinguished by his long, thick, and rather upright coat, forming a most tremendous ruff about the neck, but short and smooth on the head and ears. They are mostly of a pale yellow or cream colour, and lighter on the lower parts. Some are white, some few black, and others, but very rarely, spotted; the head broad towards the neck, and narrowing to the muzzle; ears short, pointed, and erect; nose and eyes mostly black; the tail large and bushy, and invariably curled in a ring upon the back. Instances of smooth or short coated ones are very rarely seen. In England he is much more familiarly known by the name of fox dog, and this may originally have proceeded from 'his having much affinity to that animal about the head; but by those who in their writings describe him as a native of Pomerania, 
he passes under the appellation of the Pomeranian dog.

"In general opinion as a house dog he is held in but slender estimation, being by nature frivolous, artful, noisy, quarrelsome, cowardly, petulant, deceitful, snappish and dangerous with children, without one prominent property of perfection to recommend him. This breed is common in Holland, and has occasionally been introduced as a hieroglyphic by the caricatured partisans of the House of Orange (in opposition to the pug) to ridicule the patriots in their political disputes. . . The largest of these dogs are used for draught purposes in different countries, and it may with wellfounded reason be presumed that to these or a race somewhat similar may be attributed Took's account of dogs in his view of the Russian Empire."

The account in question describes the usual Esquimaux as they are used for drawing sledges, and which have been and still are found so useful by Arctic explorers.

Until within the past half dozen years or so, the White Pomeranian was the only variety known to any great extent in this country, and this was a pure white dog some $20 \mathrm{lb}$. or so in weight. He did not bear a great reputation for amiability, and his best friends could not say that he was anything more 
than snappish and particularly ill-tempered with children and with strangers. A few years ago there was a mad dog scare in New York, and in some quarters the origin was said to be traced to the Spitz dogs, a great many of which were destroyed without any proof being forthroming either one way or the other. Still, I do not think it was altogether on account of their ill-temper that they have never popularised themselves in this country, but white specimens of excellence were most difficult to produce, especially when accompanied by dark hazel eyes and a perfectly black nose. Fawn or fallow marks on the ears were continually appearing, and red noses were far more common than black ones. Then there was the difficulty in washing and in getting them up for show, in which latter respect white dogs are always more troublesome than coloured ones.

R. D. Blackmore in one of his charming stories introduces a pretty character in Bardie with her "Pomyoleanian dog," and the novelist must, in so agreeably alluding thereto, have held a better opinion of the Pomeranian than do the majority of people.

Classes have been provided for the variety at early shows, but they were, as a rule, badly filled, and continued to be so until recently. Still, in the first 
volume of the "Kennel Club Stud Book," they are allowed a classification, and no fewer than fortythree dogs and bitches are entered, a large majority of which have no pedigree whatever, nor is anything said as to their being bred abroad. These early Pomeranians were, I take it, in the hands of private individuals, who took no trouble to keep records of the puppies so far as either sire or dam was concerned. After the shows of the sixties, in most cases the Pomeranians had to compete in the variety classes, and perhaps the most notable dog, and the handsomest of his day, was Mr. J. Fawdrey's Charlie, indeed, I do not recollect having seen so perfect a white specimen since his day, excepting perhaps. Miss Creswell's Little Snow, winner at a recent show of toy dogs held at Westminster.

A great change has, however, been recently brought about in the Pomeranian so far as this country is concerned; the whites have had their noses put out of joint, their places being more than supplied by the black specimens, and others fawn or pale red in colour, chocolate or brown, and occasionally these hues are diversified by parti-coloured specimens. I do not believe that all these Pomeranians of different colours recently produced, have sprung from one stock, whatever may have been the case a hundred or more years ago. Most 
of these charming black, or red, or chocolate specimens are much smaller than the original whites, $4 \mathrm{lb}$. and $6 \mathrm{lb}$. weight each being not unusual, and moreover these "toys" are not snappish and ill-natured, their temperament and disposition being more what one likes to see in a companionable dog.

That these comparatively new varieties, at any rate new to this country, have a future before them I do not doubt at all; they are in enthusiastic hands and a specialist club has been formed to look after their interests, which is giving particular attention to the smaller varieties. Her Majesty the Queen has a companionable and handsome little fellow, a beautiful red sable called Marco, and the Right Hon. W. E. Gladstone's favourite dog is a little black specimen which glories in the name of Fritz. Not long ago the club, established in $189 \mathrm{I}$, combined with the Toy Spaniel and other clubs, and had a show of its own, no fewer than fourteen classes for Pomeranians being provided, and these attracted sixty odd entries, including a number of the most charming specimens ever brought together.

The royal favourite Marco is now about five years old. This is what Mr. T. Marples, who specially interviewed the little dog at Osborne for the British Fancier, says of him :-

"From a fancier's or exhibition point of view 
Marco occupies a high position, and, in short, may be described as a most typical specimen of his race. In substantiation of this we may point to the fact of his having at the late Kennel Club Show, the first time he was ever exhibited, carried off not only first prize in his class, but also the gold medal given by the Pomeranian Club. In colour, Marco is a deep red sable, excepting on the tail and hind feathering, which merges into a very pale tint of the same hue, almost white. In build he is proportionate and symmetrical, scaling probably about $\mathrm{s} 2 \mathrm{lb}$. in weight. $\mathrm{He}$ has the correct coat, which is both straight and profuse, especially about the neck, where it forms a dense frill or mane. He is heavily feathered about the thighs, and his caudal appendage, which is quite orthodox in its carriage, is covered with a profuse quantity of hair, which, fountain-like, flows over his back. His eyes, in colour, match the colour of the dog's body, and he is bright, sharp, and intelligent looking, with small, erectly carried ears, which appear sensitive to every sound.

"Fortunate in being the recipient of such Royal care and companionship, Marco is a most attractive little fellow and doubtless deserving of the caresses lovingly bestowed upon him by his Royal mistress."

Her Majesty has, however, other Pomeranians, which are more or less fawn and white in colour, 
including a particularly charming specimen, bred at Windsor, and winner of leading prizes wherever shown, called Fluffie. This beautiful little creature appeared, with several other of Her Majesty's Pomeranians, at Cruft's show in I892, where they carried away a great number of prizes. At this gathering there were ninety-four Pomeranians entered, although not nearly that number of dogs were benched, many being entered in more than one class. All were of the small size, and possibly in the course of a few years the royal example will be followed, and the Pomeranian become a fashionable variety.

At the present time Miss Hamilton, of Seend, Wiltshire, has a particularly choice and interesting kennel of Pomeranians, including several good whites, some charming blacks, and specimens of other colours, many of which have been bred by her. The diminutive orange and white dog Prince of Orange is especially choice, weighing about $5 \frac{1}{2} \mathrm{lb}$. This exquisite little creature was first shown by Mrs. Gordon Lynn, of Southsea, who at one time possessed an excellent collection of Pomeranians. Indeed, honours in this respect may be said to have been pretty equally divided between Her Majesty, Mrs. Gordon Lynn, Mrs. Thomas, and Miss Hamilton.

Mrs. Thomas, of Ealing Dean; has at the present time a valuable and an unique kennel of the variety. 
Here we find only blacks and an occasional chocolate and fawn or two; her Schatzel, Black Boy and Queen Bee; with Lady Dinah, but $3 \frac{1}{2} \mathrm{lb}$. weight, being perhaps the best. Most of Mrs. Thomas' dogs have been imported from Germany, and there is considerable risk in so doing, as many of them die before becoming acclimatised, but when once nicely settled down they are healthy and strong, and quite as able to withstand the rigours of our fickle climate as our own toy spaniels and delicate terriers.

The points and description of the Pomeranian, as drawn up by the club, are as follows :

"Appearance.-The Pomeranian in build and appearance should somewhat resemble the Chow Chow, but the head must be much finer and the ears closer together, and in coat he should be almost a duplicate of a well-coated Scotch collie, with the difference that his coat should be softer in texture, long and lustrous, with a fluffy under-coat, and standing out from the body more than does the collie's. He should be a compact, short-coupled dog, well knit in frame, with his tail curled tightly over the back, and covered with long, flowing hair. His head and face should be foxlike, with small, erect ears that appear sensible to every sound; he should exhibit great intelligence in his expression, 
docility in his disposition, and activity and buoyancy in his deportment.

"Head.-Somewhat foxy in outline, or wedgeshaped, the skull being large in proportion to the muzzle, which should finish rather fine, and be free from lippiness. The head in its profile may exhibit a little 'stop,' which, however, must not be too pronounced, and the hair on head and face must be smooth or short-coated.

"Eyes.-Should be medium in size, rather oblique in shape, not set too wide apart, bright and dark in colour, showing great intelligence and docility of temper. In a white dog black rings round the eyes are preferable.

"Ears.-Should be small, and carried perfectly erect or pricked, like a fox's, and, like the head, should be covered with soft, short hair.

"Nose.-In black, black and tan, or white dogs the nose should be black; in other coloured Pomeranians it may more often be brown or liver-coloured, but in all cases the nose must be self and not particoloured, and never white.

"Neck and Shoulders.-The neck, if anything, should be rather short, well set in, and lionlike, covered with a profuse mane, and frill of long, straight, glossy hair, sweeping from the under jaw, and covering the whole of the front part of the 
shoulders and chest, as well as flowing on the top part of the shoulders. The shoulders must be tolerably clean, and laid well back.

"Body.-The back must be short, and the body compact, being well ribbed up and the barrel well rounded. The chest must be fairly deep and not too wide.

"Legs.-The fore legs must be perfectly straight, of medium length, not such as would be termed either 'leggy' or 'low on leg,' but in due proportion in length and strength to a well-balanced frame, and the fore legs and thighs must be well feathered.

"Tail.-The tail is a characteristic of the breed, and should be well twisted right up from the root tightly over the back, or lying flat on the back slightly on either side, and profusely covered with long hair, spreading out and flowing over the back.

"Coat.-Properly speaking there should be two coats, an under and an over coat, the one a soft, fluffy under-coat, and the other a long, perfectly straight, and glossy coat, covering the whole of the body, being very abundant round the neck and fore part of the shoulders and chest, where it should form a frill of long, flowing hair, extending over the shoulders, as previously described. The hindquarters above the hocks should be similarly clad with long hair or feathering from the hocks down- 
wards, like the collie. The hair on the tail must be, as previously described, profuse, and flowing over the back.

"Colour.-The following colours are admissible: White, black, blue, brown, black and tan, fawn, sable, red, and parti-colours. The whites must be free from lemon or any colour, and the blacks, blues, browns, black and tans, and reds free from white. A few white hairs in any self-colours shall not disqualifv, but should be discouraged.

"Size.-No dog over 2olb. weight shall be eligible to take a prize; the smaller specimens to be encouraged, and, where practicable at shows, the classes to be divided by weight, viz., 'under' and 'over' 7lb."

Scale of Points.

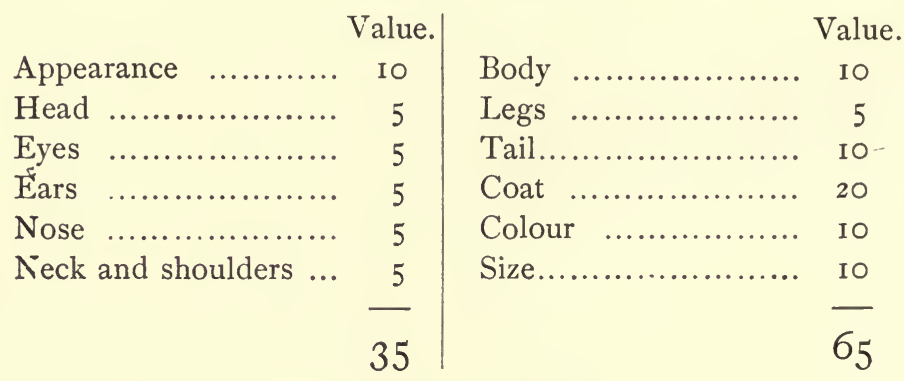

Grand Total, 100. 



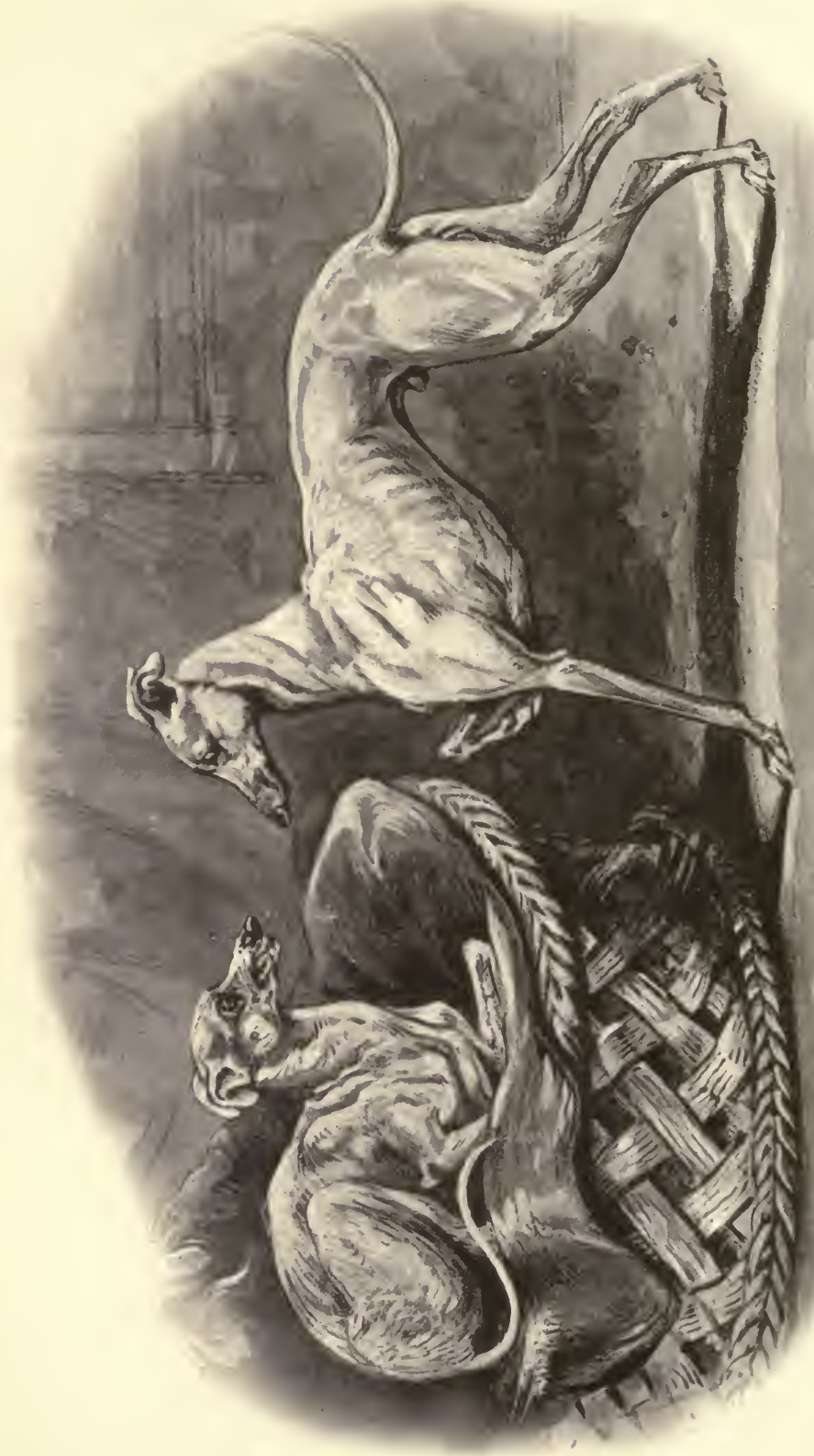




\section{CHAPTER XVI. \\ THE ITALIAN GREYHOUND.}

THIS graceful and fragile little creature, with the equally choice Maltese dog, may not survive long in this country. He has never been a particularly great favourite, owing doubtless to his delicate constitution and the great difficulty there has always been to produce perfect specimens of the ordinary English greyhound in miniature, which the so-called Italian variety undoubtedly ought to be, though in proportion the limbs of the latter are more slim, and were never ordained by nature for rougher work than playing on the lawn, or having a romp in the dining room.

Here is what a writer at the commencement of the century says of what he calls "a diminutive native breed, which seem only calculated to sooth vanity and indulge frivolities: these dogs are so deficient of the spirit, sagacity, fortitude, and selfdefence of every other sort of the canine race as not to be able to officiate in the services of domestic 
alarm and protection; and in consequence are dedicated only to the comforts of the tea table, the fire-side carpet, the luxurious indulgences of the sofa, and the warm lap of the mistress. As a proof of the delicacy of this little animal, it is averred that if held up by its legs the texture of the skin is so exceedingly fine when interveningly opposed to the sun, or a strong light, that the distinct chain of the intestinal canal is truly perceptible to a nice observer." The fallacy of this must be apparent.

When the Italian greyhound became fashionable in this country there is nothing to tell us, but that it was a favourite at Court in the time of the Stuarts there is no doubt whatever, though I fancy at that time it was a bigger and stronger animal than it came to be at the early part of this century. In the picture gallery at Hampton Court there is a portrait of the Queen of James I. in the act of mounting a horse attended by a black servant. In the picture are included several Italian greyhounds, some of them fawn in colour, others blue and blue and white, and they are undoubtedly going to accompany their royal mistress on her equestrian excursion. These dogs, although much of the make and build of the Italian greyhounds of the present day, appear to be somewhat larger, going perhaps up to $\mathrm{r} 6 \mathrm{lb}$. in weight; still they are unmistakably of the same 
stamp we have now, and their appearance in the picture is sufficient proof that such dogs were fashionable very early in the seventeenth century, for James came from Scotland to be King of England in 1603 .

It has been said that the Italian greyhound was a native of the South of France as well as of the country from which it takes its name. Never particularly numerous in England, it was more so once than is the case now, and when it was utilised to cross with the terrier in the North of England for the purpose of providing dogs for "running races" and for " coursing rabbits," it was not difficult to procure specimens, especially in Lancashire and in parts of the Black Country. Many of these "running dogs" were not more than $\mathrm{I} 2 \mathrm{lb}$. or I $4 \mathrm{lb}$. in weight, and I have seen such that must have contained at least three parts Italian greyhound blood. Some of the original crosses produced little dogs scarcely strong enough in the jaws to hold a rabbit, but such could go at a rare pace for from one hundred to a couple of hundred yards. These were again crossed with the terrier, and in due course the variety now acknowledged as the "whippet" was produced. I am alluding to the smaller-sized "whippet," for the larger specimens are undoubtedly the product of the ordinarv greyhound and some other variety, bred 
continually to the greyhound until little more than greyhound remains. However, the whippet is still known in many localities as an "Italian," which he assuredly is not, although, as I have said, the blood of the fragile race runs in his veins.

At our early shows classes were, as a rule, provided for Italian greyhounds, but even in those days. of large entries, not more than a dozen or so. appeared on the benches, and these were mostly in the hands of the dealers. The first volume of the "Kennel Club Stud Book" had forty-one entries of Italian greyhounds, the last published, that of 1893 , had but three new entries. Their delicacy is, of course, the cause of their rarity, and this, I fancy, has been emphasised by the mischievous custom prevalent thirty years or so ago of producing them as small as possible. Mere mites some of them were, not more than $4 \mathrm{lb}$. or $5 \mathrm{lb}$. weight, with legs. thinner than the shank of a Broseley straw pipe, skull round or apple-headed, and a mouth or jaw very much overshot. Most of the smallest specimens were so, and even that extraordinary little creature Molly, so successfully shown by the late Mr. W. McDonald, was very much overshot. Still she was one of the choicest specimens ever produced, and, I believe, did not live to be beaten. She was just under $5^{\mathrm{lb}}$. in weight. But she, like all 
others of her race, was very delicate, which no doubt arose from continued in-breeding. $\mathrm{Mr}$. McDonald's Duke was larger, but equally good in other respects, and for a time these two won first and second at all the shows where they competed; this was about twenty to twenty-three years ago.

"Stonehenge" alludes to one dog, Gowan's Billy, the best of his day, about 1857 , where grandsire, great grandsire, gg. grandsire, ggg. grandsire, and gggg., were all the same dog. He was a lovely specimen in appearance, but, as would certainly be the case under such circumstances, his stock was delicate in the extreme.

As a rule, the males of the Italian greyhounds do not approach the females in diminutiveness and elegance of form; thus the bitches beat the dogs when they meet, which they usually do in the same class, the entry in which is always so meagre as to preclude the possibility of two divisions being made.

The best classes of Italian greyhounds of recent years have, with slight exceptions been found at the Scottish shows, where Mr. Bruce, Dundee Court, Falkirk, was accustomed to exhibit some beautiful little dogs, which were certainly in advance of any we had this side of the border, his Wee Flower, 
Crucifix, Bankside Daisy, and others, being quite celebrities in their way. Mr. Bruce's entries have been missing of late, but in his place Miss H. M. Mackenzie, of New Cross, has come into prominence, and so far as I can make out, at the present time possesses the finest and most valuable kennel of Italian greyhounds in the country, and appears to be quite invincible in the show ring. Occasionally a smaller dog, as Mr. Turner's Larkfield Shrimp, has been placed at the top of the prize list, but the latter, to my mind, shows unmistakable signs of recent terrier cross. Miss Mackenzie's Juno, Sappho, Como, Dido, and Carlo, are undoubtedly very firstrate specimens, and I am told by their owner that her strains are quite as strong, hardy, and intelligent as other toy dogs, or even more so; the smallest of Miss Mackenzie's choice little creatures weighs $5 \frac{1}{2}$ lb. This is her beautiful bitch Dido, which, I need hardly say, has won several prizes, and is a grand-daughter of Jack, mentioned later on. Sappho and Carlo weigh 9lb. each in good condition, Como $6 \frac{3}{4} \mathrm{lb}$., and Juno is $6 \frac{1}{2} \mathrm{lb}$., which I take to be quite small enough for the purposes for which they are required.

In a conversation with Miss Mackenzie, I learned that there are, at the time I write, some dozen or so Italian greyhounds in her kennels, and all are 
strong and hardy, full of life and play, are never sheeted, and can stand a shower of rain as well as any other dog. Moreover, they are remarkably free from illness or disease, and no case of distemper has ever occurred in her kennels. The bitches suckle and rear their own puppies from four to six at a time, and are no more trouble than are other dogs on similar occasions. The great difficulty Miss Mackénzie finds is in obtaining fresh blood of the real Italian greyhound, such I mean as does not contain terrier cross however remote. The latter is shown where puppies come black and tan, whilst in the real article, only whole coloured or perhaps fawn and white or red and white young ones are born.

It may be interesting to note that the parent of Miss Mackenzie's kennel was a dog called Jack, purchased in 1879 in Smithfield Market from a labouring man for ten shillings. He was a beautiful dog, about I I lb. in weight, strong, symmetrical, active, thoroughly healthy, and pretty well on to eighteen years of age when he died; he never sired a badly coloured puppy. From the butcher purchaser in the market, Jack went to Miss Mackenzie, with whom he died. Of course there was no pedigree. However, ten years or more after at one of the Birmingham shows, a visitor introduced himself to 
Miss Mackenzie, admired her tiny dogs which were sired by Jack. Now comes the curious fact of the matter. The man, who came from the neighbourhood of Rugby, said his late master had, about the time that Jack was purchased, lost a dog in London similar to him in every way. The dog had been his constant companion both in the country and in town, and on the night when he was lost, had slipped out of the carriage whilst a purchase was being made, much to the regret of the master who quite failed to trace the lost dog. From certain marks and peculiarities, no doubt the Smithfield ten shilling purchase was the dog in question, indeed, so convinced was Miss Mackenzie that such was the case, that an offer was made to restore the dog to his former owner. Unfortunately, the gentleman in question had then been dead two or three years.

The parents of this dog Jack had both been brought from Italy, his sire being about $12 \frac{1}{2} \mathrm{lb}$. in weight, and said to be so strong and swift as to gain successes as a rabbit courser in Warwickshire.

No doubt the health of Miss Mackenzie's specimens is due to the fact that they are sprung from big dogs and bitches, and that no attempt has been made to cross them with the delicate, 
diminutive toy terrier. At present the specimens of her strain are growing smaller, but so long as pains are taken to breed from healthy, sound parents, there is no reason to doubt that the Italian greyhound in such good, careful hands may become fashionable. In a perfect specimen elegance is "caninified," if such a word may be used, and it is to be regretted that there are not more persons who at present take any interest in the variety. So far as I can make out, a Mr. Anstice, of Hammersmith, is about the only other person who of late years has given much attention to their breeding. I believe he has not hitherto exhibited any of his dogs.

That the Italian greyhound can be appreciated by others not so civilized as ourselves, is proved by the statement which recently appeared in the papers, that the Matabele monarch, Lobengula, before he became our enemy, quite fell in love with an Italian greyhound he saw at Johannesburg. For a long time its owner, Mr. Luscombe Searelle, refused to part with his favourite, but in the end struck a bargain, he receiving two hundred head of cattle for his little dog. The black king was very much pleased with the exchange, which he left in charge of two of his chiefs, with the orders, should any evil happen to the dog, the chiefs' lives would be forfeited. 
The latter came to pass soon after, as the men fell in battle, but what became of the dog we are not told.

In disposition the Italian greyhound is kindly and affectionate, and in temper equitable. $\mathrm{He}$ is little use as a watch dog, nor will he kill vermin; he is just a pet and an ornament and nothing more, though he can do with more exercise than many of the toy spaniels, and from the time he leaves his dam ought to have unlimited run, and be free from confinement. This is the only means by which his unique elegance of form can be obtained and perpetuated. In weight he ought to be not more than $9 l b$. at the most, the smaller the better, so long as he is strong and robust, and not apple-headedsome modern specimens are the latter to an alarming extent, which to my mind shows a terrier cross, as does a compact, well-ribbed, houndlike body. The Italian greyhound in shape, and in everything else but in colour, should be like an ordinary greyhound, but throughout much slimmer, less muscular, and more fragile, even taking size into consideration; head, ears, eyes, feet, body, shape, \&c., such as are to be found on a miniature Master McGrath or Fullerton. Tulip or erect ears are bad and ugly. Colour, self or whole coloured, fawn in various shades is the most common, black we seldom see, 
white not more frequently, and, although blue or slate is most acceptable as a hue, it is long since I have seen a specimen of such a colour. Red I do not care for, and when pronounced in darkness, to my way of thinking, points to an off cross. Dark shadings are undesirable, and a little white on the breast or on the feet, is no more than a slight handicap; I mean that if judged by points, a white or pale chest, a white foot, or even two white feet, where in other respects the colour was good, and the general formation perfect, the dog so marked should have precedence over a dog worse in formation and character, even though such be perfect in colour.

Like all other varieties, the Italian greyhound has a distinctive character of its own, which is strongly displayed in its high and haughty action when walking, trotting, or galloping. Dr. Walsh called this peculiar action "prancing," nor did he describe it otherwise than correctly, as he did all things he took in hand. The Italian greyhound proper was never bred from any of our ordinary greyhounds, or even crossed with them, although a lot of nonsense inferring such has been the case I have seen published. He is as much a variety of the canine race as the St. Bernard, mastiff, and foxhound. 
I should apportion the points as follows:

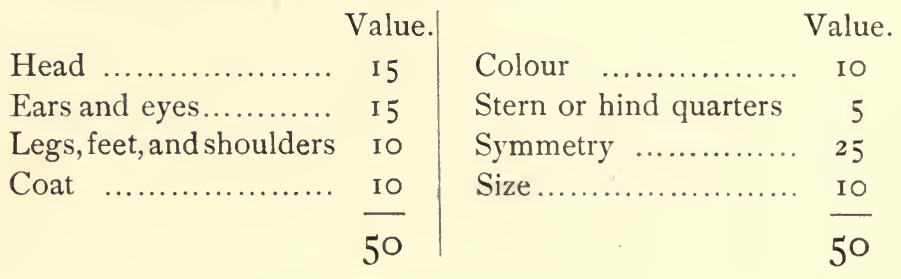

Grand Total, 100. 



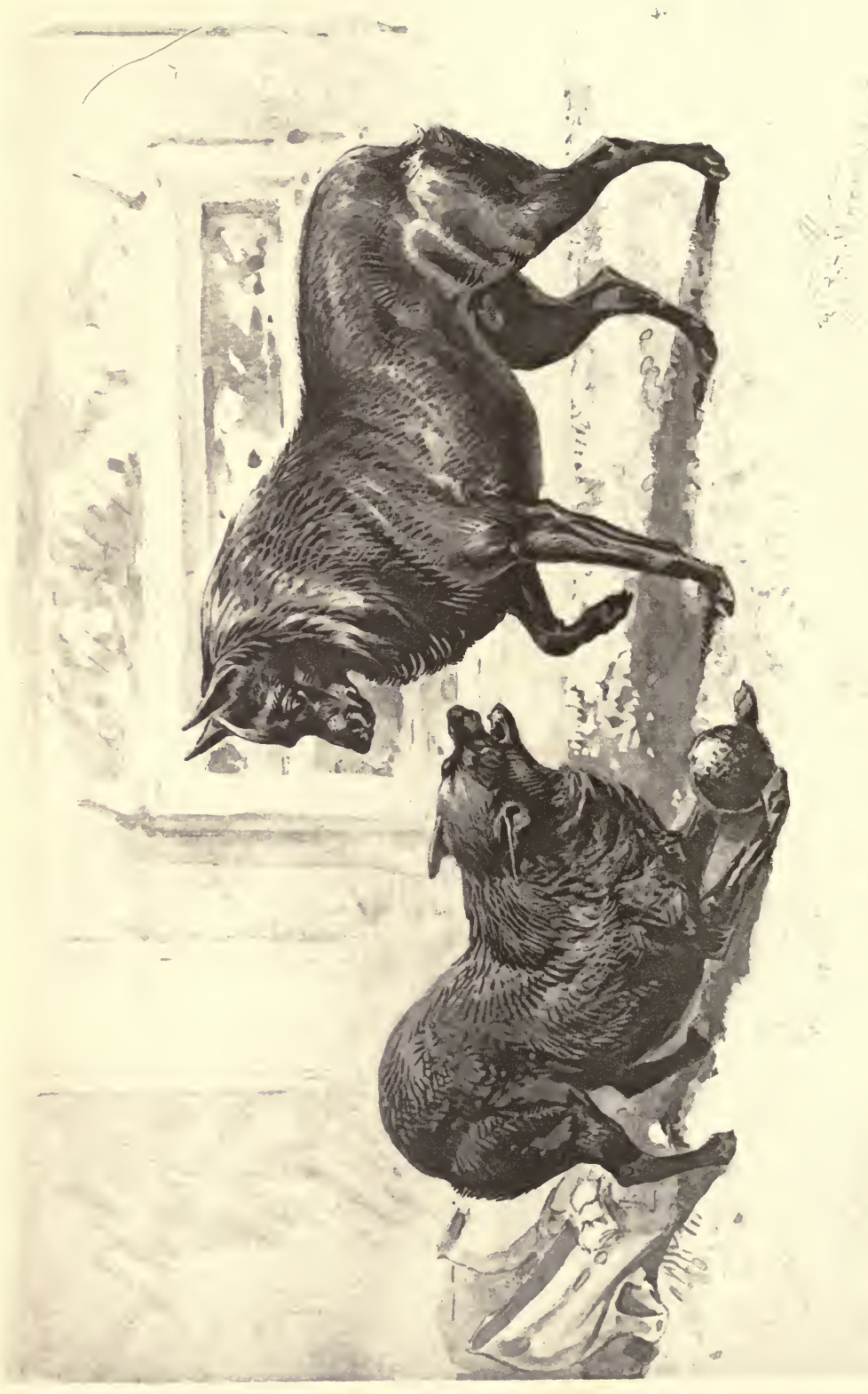




\section{CHAPTER XVII.}

THE SCHIPPERKE.

HERE is a quaint Dutch little dog which since its introduction into this country, about four years ago, has become one of ourselves, and I fancy will now stay with us and develop into one of our British dogs as the Italian greyhound and the German boarhound have done. Pronounced "Skipperkee," when at home, he is found in the Dutch canal boats, where with the captain he rules the crew, hence his name. He there acts as a careful watch and guard, will kill rats when required so to do, and generally proves himself to be an engaging little companion.

That he is undoubtedly the latter there can be no doubt whatever; none of our native breeds are livelier or perkier than he; few so lively; and ever on the alert, it is no doubt on this account that he has taken the fancy of such a dog loving nation. as ourselves. The Schipperke ought to be born without a tail, or at any rate with a merely rudimentary stump, but when he is produced with the 
caudal appendage intact it is of course cut off, and as the operation is performed skilfully, not even an expert can tell whether he is naturally or but artificially tailless. In Holland there is a dark fawn-coloured variety of the breed, but here nothing but black is acknowledged, though I consider those fawn in hue are by no means displeasing to the eye, and possess quite as much character as the blacks. The latter breed true to colour, and it is very unusual for one of any other hue to be produced from black parents, still this does occur at times, but such as are "off" colour and have much white about them should be at once destroyed, as they are in most instances.

A friend of mine who keeps several Schipperkes in conjunction with his deerhounds, gives the former a very high character. He says they make " excellent house dogs, being capital guards, ever on the alert and always busy, the latter being one of their prevailing characteristics. As companions they are affectionate and docile, will take the water freely, are good swimmers, and can kill rats and hunt rabbits almost as well as some of our terriers. When properly kept and attended to, they are absolutely free from any offensive odour. In constitution they are hardy and healthy, and altogether most desirable as house dogs." 
This is a good character, but I do not know that it is more than they deserve. Their size-about $\mathrm{I} 2 \mathrm{lb}$. -makes them particularly adaptable as house dogs, and so does their colour, especially in towns, where a white dog requires repeatedly tubbing if it be desired to keep his jacket clean and in good order. Of late there has been a tendency to increase the size of the Schipperke, and on more than one occasion prizes have gone to animals considerably over the stipulated standard. In Belgium two sizes appear to be recognised, the smaller varying from about $9 \mathrm{lb}$. to $\mathrm{i} 2 \mathrm{lb}$., the larger from $\mathrm{I} 2 \mathrm{lb}$. to $2 \mathrm{olb}$. I do not like the big ones at all, and I hope such will never obtain the support of the Schipperke Club in this country. Twelve pounds is quite big enough, and it is such a weight as can be continued and established without losing constitutional strength, bone, and general symmetry. Still, the specialist club in Belgium, which was established in 1888 , encourages the two sizes, and at the exhibitions in that country each has a separate classification. The English club to look after the interests of the variety was established in I890, and the Kennel Club granted an entry in the "Stud Book" three years later.

The following are the points and description of the Schipperke as adopted by the English club: 
"Head.-Foxy in type, skull should not be round, but broad, and with little stop. The muzzle should be moderate in length, fine but not weak, should be well filled out under the eyes.

"Nose.-Black and small.

"Eyes.-Dark brown, small, more round than oval and not full ; bright and full of expression.

"Ears.-Shape-Of moderate length, not too broad at the base, tapering to a point. CarriageStiffly erect, and when in that position, the inside edge to form as near as possible a right angle with the skull, and strong enough not to be bent otherwise than lengthways.

"Teeth.-Strong and level.

"Neck.-Strong and full, rather short, set broad on the shoulders and stiffly arched.

"Shoulders.-Muscular and sloping.

"Chest.-Broad and deep in brisket.

"Back.-Short, straight, and strong.

"Loins.-Powerful, well drawn up from the brisket. "Fore legs.-Perfectly straight, well under the body, with bone in proportion to the body.

"Hind legs.-Strong, muscular, hocks well let down.

"Feet.-Small, catlike, and standing well on its toes.

"Nails.-Black. 
"Hindquarters. - Fine compared to the foreparts, muscular, and well developed thighs, tailless, rump well-rounded.

"Coat.-Black, abundant, dense, and harsh, smooth on the head, ears, and legs, lying close on the back and sides, but erect and thick round the neck, forming a mane and frill, and well feathered on back of thighs.

"Weight.-About I alb.

"General Appearance.-A small cobby animal with sharp expression, intensely lively, presenting the appearance of being always on the alert.

"Disqualifying Points.-Drop or semi-erect ears. "Fauits. - White hairs are objected to, but are not disqualifying.

\section{Standard of Points for Judging.}

\begin{tabular}{|c|c|c|c|}
\hline \multicolumn{2}{|c|}{ Value. } & \multicolumn{2}{|r|}{ Value. } \\
\hline Head, nose, eyes, teeth & 20 & Hind legs ............... & 5 \\
\hline Ears …............... & IO & Feet $\ldots \ldots \ldots \ldots \ldots \ldots$ & 5 \\
\hline Neck, shoulders, chest & 10 & 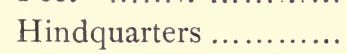 & 10 \\
\hline Back, loins....... . ...... & 5 & Coat and colour ...... & 20 \\
\hline Fore legs $\ldots \ldots \ldots \ldots \ldots$ & 5 & General appearance ... & 10 \\
\hline & & & \\
\hline
\end{tabular}

Perhaps no other variety of dog has so soon been acknowledged by our English $\operatorname{dog}$ lovers as this. 
Most of the leading shows now provide classes for him, the club gives challenge and other special prizes to its members, and already there are many persons who keep quite large kennels, most of the best specimens therein having, however, been purchased on the continent. Mr. I. Woodiwiss and Mr. E. S. Woodiwiss (Derby) have both owned and still own excellent specimens; Mr. W. H. Singer, Frome; Mrs. Hyacinth Cosier, London; Mrs. E. Heard, Greenhithe; Mr. W. R. H. Temple, Streatham; Mr. E. H. Fuller, Mr. J. H. Hill (honorary secretary to the club), Mr. G. R. Krehl (one of their very earliest admirers), Mr. E. Joachim, Mr. B. W. Moore, Derby, have all at one time or another proved their admiration for the black little dog by owning and exhibiting on our show benches specimens good enough to win prizes. The Schipperke Club held special shows of their variety in conjunction with the Toy Spaniel and other clubs at Westminster Aquarium, in 1892-3, where there were about thirty competitors on each occasion; and there were nineteen entries at the Kennel Club gathering which took place at the Crystal Palace in 1893 . 



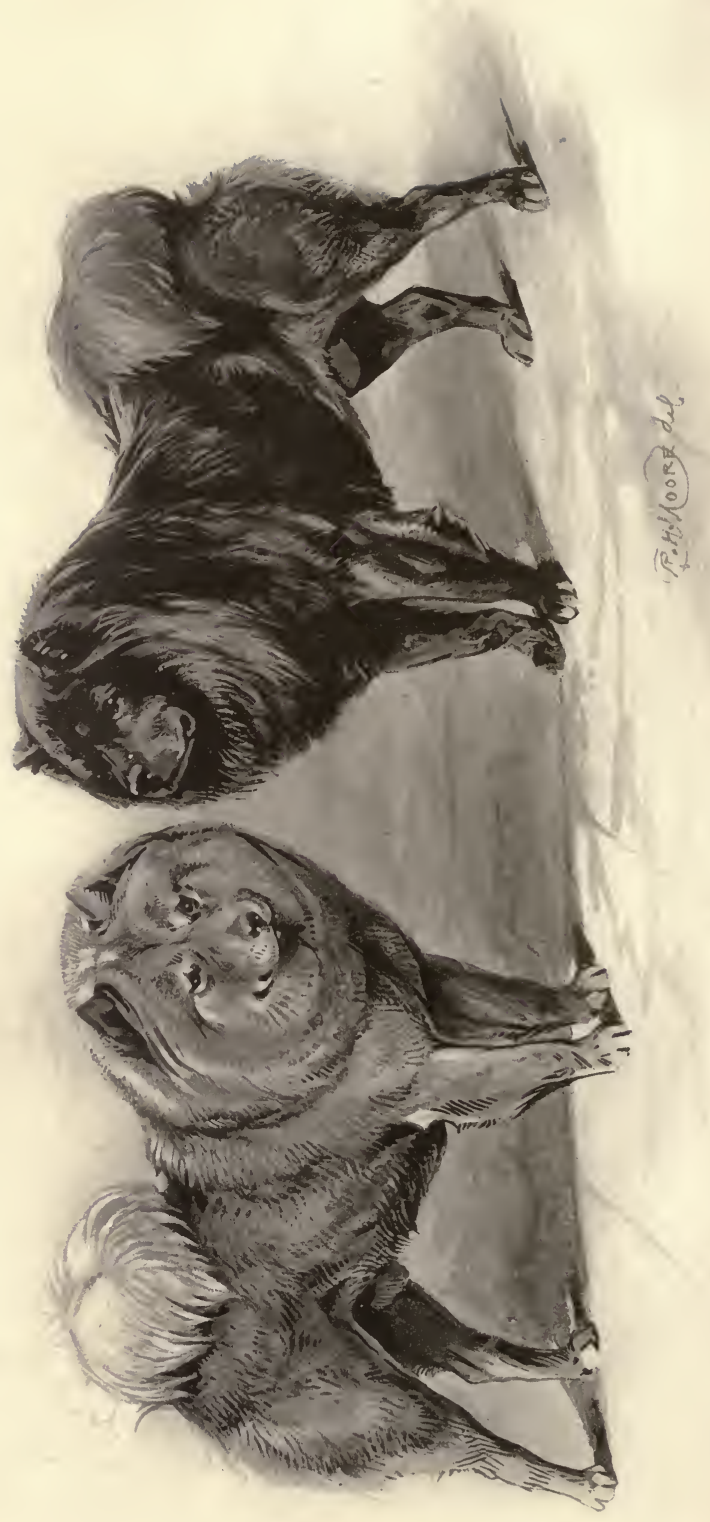




\section{CHAPTER XVIII. \\ THE CHOW-CHOW.}

Perhaps I may be taken to task for introducing the above Chinese dog in a book purporting to deal with British modern varieties. However, the Chowchow is now so common amongst us, he has classes specially provided for him at our leading exhibitions, that he could not with any degree of satisfaction be passed entirely over. Mr. Moore shows by his pencil what the dog is like in the flesh as we have him here, but not as he is butchered and hung up for sale in his native country.

Our Chow-chow - a native of the Celestial empire -is so called because he is used edibly, "chowchow" being a " pigeon English" expression for food. At home he is common for that purpose, is butchered in the usual fashion, and may be seen any day hanging up in the meat shops in Canton and elsewhere; and the flesh looks very nice and dainty too. As a fact, the Chinese do not give their dogs so much animal food as we give ours, feeding them 
mostly on rice. They believe that the flesh of the dog possesses unusual medicinal properties, but what these properties are we barbarians here have yet to learn. Alongside these carcases of dogs may be seen the four paws of poor pussy, which, suitably cooked, are considered a great delicacy, and evidently as much esteemed by the Chinese as pigs' feet are by the English and the natives of other countries. It is strange somewhat that whilst only the paws of the cat are eaten, the whole of our friend the dog is converted into food.

The restaurants in Canton and in other large centres mostly provide dog soup; other savoury stews and ragouts are concocted from his flesh, and I am told that such are by no means unpleasant, and form in a great measure the usual food of the middle classes.

Mr. W. K. Taunton, who is the great authority in this country on foreign dogs, kindly forwards me the following notes :-

"In China are found several different breeds of dogs, many of which bear a very close resemblance and are probably identical with some of the breeds. of other countries. As an instance, there can be little doubt the hairless dog of China is the same as the Mexican hairless dog, and the crested dogs bear a striking likeness to the dogs which have 
lately been exhibited and described as African sand dogs. There are also small spaniels which, though differing in type from our present toy spaniels, are in all probability distantly related to them.

"The variety of Chinese dogs which is best known in this country is the one most commonly to be met with in its native country. This is the edible dog, sometimes described as the wolf dog, but better known here as the Chow-chow. They are undoubtedly a very old breed, in many respects resembling the Esquimaux and the dogs of the Arctic regions, especially in the carriage of tail, ears, and general expression. Scientists would find it an interesting inquiry to determine whether the Chinese dogs are bred from the canine race of the Arctic regions and Northern Europe or vice versâ.

"Many of these dogs have a very keen scent, and in the north of China, where I imagine they are of a somewhat larger size than elsewhere, they are used in packs for hunting purposes.

"The orthodox colours of the Chow-chow are jet black and dark red. I have, however, seen many good specimens of a lighter colour, and at one time I owned a black and tan dog which was an exceptionally typical specimen. Whether this colour was the result of crossing the black and red I do not know, but as I have been frequently asked my ex- 
perience of breeding the colours together, I may say here that I have found the puppies come either a distinct black or red.

"A writer in the Field some time ago said that white specimens were not uncommon, and he described these Chow-chows as useless excepting as guards or watch dogs, and said they were great cowards. It may be interesting to mention that some years since a well-known breeder and judge of Scottish terriers, residing in Scotland, was good enough to tell me of a pair of puppies which had just arrived by vessel, and which were supposed to be Esquimaux. I decided to buy them, but on arrival I saw they were crossed with something, and on examining their mouths was satisfied there was Chinese blood in them. These puppies were a very light fawn. When old enough I mated the bitch with a black dog of my own. In due course she presented me with five puppies, all jet black, but my disappointment was great on finding that not one of them possessed the special feature of the breed-a black, or rather blue-black, tongue. My first impulse was to destroy the litter, but fortunately I did not adopt this course, as in a short time I observed small black spots, which gradually increased till the tongue became the correct colour. This, however; is not always the case, and in many 
instances an otherwise good dog is useless for show purposes through the tongue remaining red, as at the time of birth, or only turning partially black. It will be evident from this that anyone attempting to produce these dogs should endeavour to retain the dark tongue so peculiar to their breed, a peculiarity which I believe would quickly be lost without care in breeding. Other qualities which should be aimed at are a broad forehead, nose rather broader than the Esquimaux, small erect ears, carried well forward, small black eyes, a thick coat, coarser than the Pomeranian, small round feet, the tail curled over the back, and straight hocks.

"The Chow-chow is a very companionable dog, and shows great affection for his owner, though many of them have a will of their own, and are more quarrelsome with other dogs than many other of the foreign races. It is frequently thought that these and other foreign dogs require special. feeding and treatment, but I have never found it so, and mine are fed the same as my mastiffs and bloodhounds. In China, where the natives eat these dogs, they are fed largely on rice.

"There is a short-coated variety of the Chowchow, but in this the nose is rather more pointed, and the coat resembles the under coat of the Esquimaux. Chow-chows live to a good age, and 
are hardy dogs, but many are carried off by distemper, from which they appear to suffer more severely than our native British breeds."

From the inquiries I have made elsewhere, and from my own experience, I can endorse all that $\mathrm{Mr}$. Taunton has said of the variety. Both the black and the red Chow-chows, when in full coat, are very handsome animals, in this respect comparing favourably with our native varieties - the collie, for instance. $\mathrm{He}$ has, howevèr, a somewhat wild-looking appearance, and his resemblance to the quasi-domesticated dogs of the Arctic regions is somewhat against his popularity. A few years ago the mate of a trading vessel, with whom I was acquainted, brought home with him from Pekin a very handsome specimen of the Chow-chow, a black one with a lovely tail and a coat like deep pile velvet. In those days I kept more dugs than I do now, and approached the sailor with the view of purchasing the importation. He would, however, not consent to part with his favourite, for which he had formed a great attachment, for he said "there never was a more faithful dog than he." On the very first day of landing in Liverpool the mate, sailor-like, went into the town to enjoy himself, as only sea-faring men can do after a lengthened absence from home. The dog, however, got tired 
of the public-houses, and slipped away. His owner was almost disconsolate at its loss. However, on returning to the vessel next day, the Chowchow was the first to greet him as he stepped on deck, having found its way from the centre of the busy seaport along the docks, and to his own vessel, where he had remained until his master returned. Of course on hearing this I was more anxious than ever to secure the $\mathrm{dog}$, but on making further application was informed it had been poisoned for biting a little child who was trying to pull its tail out of curl.

Perhaps here it might be well to mention that, as a rule, these foreign dogs, Chinese and Esquimaux, require no special feeding. They do well on the same food as our own, and Mr. Taunton tells me that he gives his cooked paunches and stale bread. Those, however, from the Arctic regions are very fond of fish, and in some cases it is wise to give them some occasionally. None of these foreign dogs are so quarrelsome as our own varieties, especially as the terriers, though perhaps the Chowchows are more inclined to be snarly than the Esquimaux. Of course the dingoes from Australia are not included in this character, they being actually wild, and are never thoroughly tamed and domesticated. 
A Chow-chow is from 4 olb. to about $55^{\mathrm{lb}}$. in weight, and his numerical points may be given as follows :-

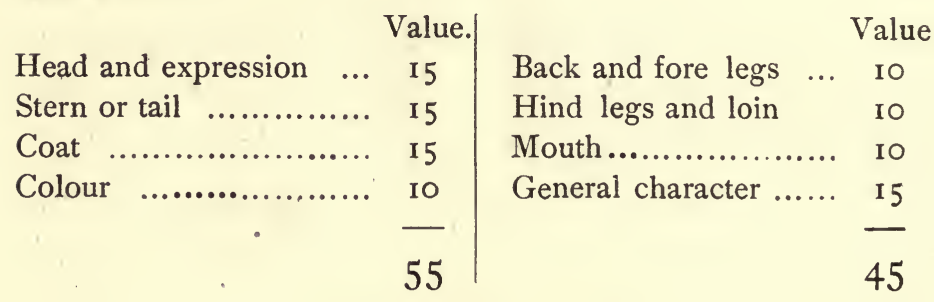

Grand Total, 100. 


\section{N D EX.}

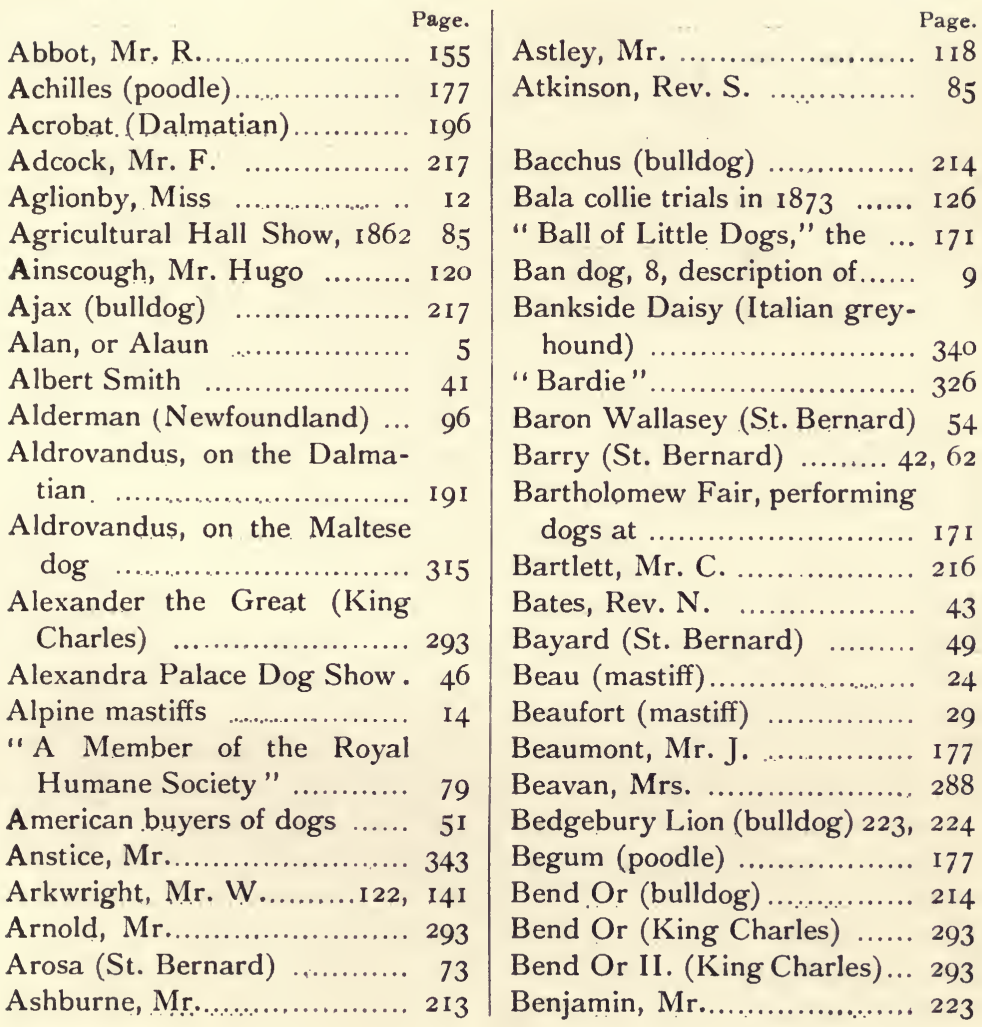


Bennett, Mr. W. C. ......... 289

Bergman (St. Bernard)........ 70

Bernard (St. Bernard) ........ 44

Bernard de Menthon and his dog, painting of

66

Berolina (Dalmatian) ........ 196

Berrie, Mr. J. W. ............. 293

Bessie Spratt (black pug)...... 274

Betterton, Mr. H. I. ... .... 49, 5 I

Bewick's drawings of the Dalmatian ...................... I 95

Bewick's drawings of the sheepdog ..................... I06

Billy (bulldog)................. 2 I I

Bingley, Rev. W. ............ Io9

Bingley's "Natural H'story" 82

Birch, Messrs.................. I2I

$\begin{array}{llll}\text { Birmingham Show in } 1880 & \ldots & 85\end{array}$

Bismark (Newfoundland)...... 96

Bissel, Mr. J. ................... I I 5

Black and White on the black pug ......................... 27 I

Black Bess (black pug)........ 274

Black Boy (Pomeranian) ...... 33I

Black Gem (black pug)........ 274

Blackmore, Mr. R. D. ........ 326

Black Prince (Dalmatian) $\quad \ldots \quad 196$

Black Prince II. (Newfoundland) ......................... 96

Black pug, a distinct variety.. 278

Blamey, Mrs. ................. 293

Blenheim Palace, few spaniels bred there.................... 292

Blenheim spaniel catching rabbits ....................... 289

Blenheim spaniels .............. 28 I

Blenheim spaniels in the early shows.
Bloge.

Blenheim spaniel, originally

a sporting dog.............. 285

Blenheim spaniels killing rats 289

Bligh-Monk, Hon. Mrs. ..... 319

Blösch, Major Fritz .......... 72

Boddington, Mr. S. .......... I I 7

Bodleian library, early por-

trait of dog in ............... $17 \mathrm{I}$

Bond, Mr. A. ................. 274

Bowers, Mr. E. H............ 223

Bowsie (Blenheim) ............. 293

Boynton, Mr. H................ 2I I

Brassey (pug) .................. 273

Brassey, Lady.................. 268

Brave Tory (bob-tailed sheep-

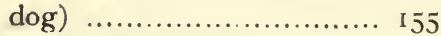

Bray, Isaac, truffle hunter $\ldots$ I85

Brewer, Mr. J. ............. 177

British Fancier, the, on the Pomeranian ................. 328

British Monarch (bulldog) ... 223

"British Quadrupeds "........ Iog

Britomartis (bulldog) .....223, 224

Brittain, Mrs. .................. 266

Bruce, Mr. .................... 339

Buffon on the pug .............. 257

Buggs, Mr. .................... 293

Bulldog, antiquity of the ..205, 207

Bulldog as a companion ...... 227

Bulldog Clubs .................. 228

Bulldog Club Shows .......... 229

Bulldog, a description of, by the Bulldog Club ........... 245

Bulldog, difficulties in breeding 228

Bulldog fanciers ................ 221

Bulldog, looked down upon ... 207

Bulldog, Mr. Cyril Jackson's description of ................ 230 
Bulldog pedigrees, volume of . 223

Bulldog, pictures of

212

Bulldog; points for judging ... 245

Bulldog stalking deer

226

Bulldog, the modern 206

Bulldog Toro, description of... 2 I 7

Bulldogs in France. 215

Bulldogs about Sheffield and Birmingham, dishonest practices 216

Bulldogs at the early shows ... 214

Bulldogs ard bull baiting, 2 10, 228

Bulldogs, match between two 209

Bulldogs, Spanish

Bulldogs, the best 213

Bulldogs, Bill Tupper's.

Bulldogs (toy) 215

Bulldogs used as crosses ...... 225 Bulldogs with "Dudley faces" 224 Bumble (bulldog) ............. 214 Burgess, Mr. T. .............. 85

Butler, Mr. Clement .......... 222

Cabot (Newfoundland)........ 85

Caius, Dr. 7,280

Caius, Dr., on the shepherd's dog 106

Callimachus 314

Cameron, Miss Violet 294

Campbell, Mr. Morton ......... I 20

"Canes Melitæi" 314

Canton, dogs in 353

Captain (Dalmatian) 197

Caractacus (collie) ............. 117

Carbuncle (Ruby spaniel) $\quad \ldots \quad 294$ Carlo (Italian greyhound)..... 340 Caro (Japanese spaniel) ...... 301 Carter, Rev. Arthur 47,73
Carthew, Mrs. H.

Page.

Cassel, $\mathrm{Mr}$. I 96

Cato (Newfoundland) ....... 85

Cato saving his master ........ 86

Cats, paws of, eaten by the Chinese 354

"Cavalier's Pets," by Landseer

Chalon's (Mr. H. B.j picture of bulldogs ................ 2 II

Charlemagne (collie)..... I I 7, I 24

Charlie (Blenheim) .......... 293

Charlie (Pomeranian) ........ 327

Child (bulldog) ............... 2 I I

"China" eyes in dogs ........ I4I

"China," or Wall-eyes ....... 195

Ching Mhow (Japanese spaniel) ....................... 288

Chow-chow, anecdote of ..... $35^{8}$

Chow-chow, Mr. W. K. Taunton on the ............. 354

Chow-chow, origin of name of the......................... 353

Chow-chow, points for judging 360

Christopher (collie) ........... I I 8

"Chuffy Plant's" opinion on "bob-tails" "................. 153

Clement, Mr. ................. 169

Club, an early dog ............ I 183

Coates, Mr. W. ................ 88

Cockie (collie) ................. I1 5

Collie clubs .................... I 26

Collie, early maturity of ...... I 23

Collie, English Club's standard I 35

Collie, English Club's scale of points ...................... $\quad 136$

Collie, origin of name....... . 105

"Collie or Sheepdog" ........ I I 8 
"Coge.

"Collie or Sheepdog," extract from ................. I 26

Collie playing "Nap" ........ I 13

Collie, sagacity of the show ... II 3

Collie, Scottish Club's scale of points I $3^{8}$

Collie, Scottish Club's standard I 36 Collie, smooth, anecdotes of ... I43 Collie smooth, the best colours I4I Collie, some good bitches ...... I I 9 Collie, the.................... I05

Collie, the smooth ............. I 39

Collie trials with sheep ........ I 125

Collie (unlicensed) .............. I Io

Collie, value of smooth, in a County Court ................. I I 42

Collies, anecdotes of ........... I I I

Collies at the shows ........... II 14

Collies in $1893 \ldots \ldots \ldots \ldots \ldots \ldots$ I 20

Collies of the earlier shows ... 116

Collies, owners of specially good ones .................... I 2 I

Collies performing at the Westminster Aquarium I 33

Collies, Scottish 146

Collies (Welsh) 146

Collis, Mr. 293

Collis, Mr. Hugh ............ 289

Collis, Mrs, 293

Comedy (pug) 263

Como (Italian greyhound) ... 340 Confidence (black pug)........ 276

Conrad (Prince Charles) ..... 294 Cosier, Mrs. Hyacinth ....... 352 Couchez (mastiff) ............ 17

Courtier (Newfoundland) ...... 96 Crabtree, Mr. John .......... I3 Craven, Mr. T. T. 266
Crawley, a performing dog showman .................... I 7 I

Cremorne Gardens, dog show at, in 1863

Creswell, Miss. 327

Crib (bulldog) 212

Crib (Dalmatian) 197

Crib (F. Lamphier's bulldog) 222 Crib (Turton's bulldog) ..... 2 I4 Crown Prince (mastiff) ........ 23 Crown Prince strain of mastiffs 2 Crucifix (Italian greyhound) 340 Crystal Palace Dog Show, i 870 303,319

Crystal Palace Dog Show in I 886 287

Cunningham, Mr. C. W...... 95

" Cur," sheepdog known as II I Curzon Hall Collie Show, I 893 I34 $\begin{array}{llll}\text { Curzon Hall Show in } 1891 & \ldots & 87\end{array}$ Czar (St. Bernard) .......... 73

Dagois, M. A................. I 77

Dalmatian, appearance of spots on.................... 198

Dalmatian, causes of want of popularity.................... 198

Dalmatian, description of, by the club....................... 200

Dalmatian Dog Club ...... 197, 200

Dalmatian, fabulous stories about the .................. 192

Dalmatian, origin of the modern ..................... 193

Dalmatian, place of origin of the ......................... 192 Dalmatian, points for judging 204 Dalmatian, the, as a pointer 193 
Dalmatian, Dalmatian, the early writers on I9I

Dalmatian, performing ........ 194

Dalmatians, anecdotes of ...... I 94

Dalmatians as companions ... 194

Dalmatians, drawings of ..... I 195

Dalmatians, prices they fetch 199

Dalziel, Miss ................... 269

Dame Cavendish (bob-tailed sheepdog) ................... I55

Dame Margery (bob-tailed sheepdog) I 52, I 54

Dan (bulldog) 222

Darlington Dog Show in I87o 139

Dawes, Mr. G. A. ............ 222

Dawes, Mr. J. H. 293

Dawson, Mr. C. 292

Day Dream (Prince Charles) 293

Deer stalked by a bulldog ... 227

"Der Hund und seinen Racen" ".................... 165

"Description of the mastiff," 26

Devonshire, Duke of .......... I 3

Dicker, Rev. G. C. .......... 266

Dido. (Italian greyhound) ..... 340

Diggle, Mr.J. S. ............. I 20

Diogenes (bulldog)........... 223

Dishonest practices with regard to bulldogs 216

"Distinguished Member," A 86

Doatie Darling. (black pug) 274

Dockleaf (bulldog)............. 209

"Dog Breaking" ........ I I 2, I 70

Dog not allowed within the precincts of forests........... 7

"Dogges that dance the Morrice" I 7 I

Dogs expeditated

"Dogs. of .Scotland"
"Dogs of the British Isles,"...

Page.

I $5,83,165$ engraving of pugs in ........ 262

Dogs, performing ............ 170

Domini (poodle) .............. I 7 I

Doncaster Beauty (Dalmatian) ........................ I96

Donovan (King Charles) ..... 293

Drew, Mr. .................. 223

Droesse, Mr. Hugo .......... I 196

Druidess (poodle), the ....... I77

Dryad (bulldog).............. 223

"Dudley faces "............... 224

Duke (bulldog) ............... 222

Duke (Italian greyhound) .. 339

Duke of Bow (Blenheim) ..... 293

Duke of Leeds (St. Bernard) 47

Duke of Marlborough (St.

Bernard) ................... 49

Dunn, Mr. T.................. 266

Dür, M. H. H. .............. 49

Dutch Prince saved by a pug $25^{8}$

East-end of London, toy spaniels in .................. 29 I

Eden, Mr. P. ................. 2 It

Edward, Sydenham .......... 2 I 2

Edwards, Mr. L. ............ 309

Edwardes-Ker, Dr., on the old

English sheepdog .......... I48

Ellis, Mr. J. H. .............. 223

Emmott, Mr. J. K............. 48

England's Best (Ruby) ........ 294

English sheepdog ............. I09

Eresby, Lady Willoughby de 259

Ermine (Blenheim) ........... 293

Excelsior (Blenheim)........... 293 
Facey Romford (bulldog) ..... 223

Fairy Queen (poodle) ........ I 76

" Faked," bulldogs ........... 2 I6

Falstaff (bulldog) ............. 222

Fan (smooth collie) ........... I42

Farquharson, Mr. H. R. ... 88, 95

Fawdrey, Mr. James ......196, 327

Feeding foreign dogs .......... 359

Fido (Maltese) ............... 319

Field, The .......... I, 43, 83, 302

Fifield, Mrs.................. 272

Fifield's, Mrs., description of the black pug ............... 277

Fitzinger, Dr., on the poodle.. ${ }^{1} 6_{5}$

Flossie (Blenheim)............ 293

Flossie (Maltese) .............. 320

Forder, Mrs. ............290, 293

Foreign dogs require no special feeding 359

Foster, Mr. H. G. ............. 263

Foster, Mr. J. H. ............. I96

Foster, Mrs. J. ............... 266

Found It (bulldog)............ 223

Fowler, Mr. G. ............... 223

Fox dog .................... 323

Frigga Secunda (mastiff) ..... 29

Frisky (King Charles) ........ 292

Fritz (Pomeranian) ........... 328

Fuller, Mr. E. H. ............ 352

Fulton, Mr. R. .............. 222

Garnier, Capt., on the mastiff I5 Garniss, Mr. W. B. .......... 266 Garrod, Mr..........292, 293, 294 Garwood, Mr............. 286, 292 Gemmi d'Arth (St. Bernard) 70 George III., portrait of, with pug
George's (Bill) kennels ........ 2 $\mathrm{I} 3$

Gheud, Mr. J. B. ............. 223

Ghost (poodle), the .......... I 77

Gifford, Lady .................. 319

Gilbert, Mr. H. ............... 260

Gilbey, Sir Walter ............. 285

Gilsland, collie trials at ........ I 27

Gladstone, the Right Hon.

W. E.

328

Goblin (Dalmatian) .......... I96

Golden Ben (King Charles)... 293

Golden Phiz (Ruby spaniel)... 294

Gondola (St. Bernard) ....... 53

Goodge, Barnaby ............. 9

Gordon, Mr. P. ............... 303

Gowan's Billy (Italian greyhound) .................... 339

Grabber (bulldog) ............ 223

Grace Darling (King Charles) 293

Graves, Mr. R. V. O. ....... I 177

Graves, Mrs. ............ 293, 294

Gravesend Lino (black pug).. ?74

Great Gun (collie) ........ I I9, I 24

Green, Mr. T. H. ............. 50

Gresham, Mr. F. ............. 46

Gresham, Mr. F., on the St. Bernard ...................... 56

Greyhound, Italian............. 335

Greyhound, Italian, at the early shows .................. 338

Greyhound, Italian, best classes at Scottish shows ... 339

Greyhound, Italian, characteristics of.

Greyhound, Italian, cross running and rabbit coursing ... 337

Greyhound, Italian, described eighty years ago 
Page.

Greyhound, Italian, in the time of the Stuarts .......... 336

Greyhound, Italian, points for judging. 346

Grindrod, Mr. C. F., on the Japanese spaniels 304

Griselda (mastiff) 29

Guide (St. Bernard)

Guido (bulldog)

Gustner (St. Bernard)

Guppy, Mr. J. W.

Gwen (bob-tailed sheepdog) .. $\quad \mathbf{I}^{2}$ Gyr (St. Bernard) ............. 7 I

Haidee (Blenheim)

Haldenby, Mr. C

Hamilton, Miss

Hamilton's (Miss) kennel of Pomeranians

Hamilton, Rev. Hans

Hampton Court, painting of Italian greyhounds at........ 336 Hanbury, Mr. E. 2 I Hanlon (Newfoundland) ..... 96 Hargreave, Capt. ............ 54 Harrison, Mr. Mitchell ........ I 18 Hartley, Mr. R. J. .........196, 214 Hartley, Mrs. .................. 266 Heard, Mrs. E. ............... 352 Heatherfield Tip (smooth collie) . 14 I Hector (St. Bernard) …... 59 "Helvellyn" I 42 222 Henshall, Mr. John Heresbach, Conrad

Her Majesty's Pomeranians... $33^{\circ}$ Her Majesty's pug. 273 "Highland or Bearded Collie" I 46
Page.

" Highland Sports" .......... 225

Hilbre House Kennels (St.

Bernards)................. 45

Hill, Mr. J. H. ............. 352

Hinks, James, the late ....... 2 I 3

"History of the Mastiff " ...3, I3

Hodson, Mr. H. C. ........ 196

Hogarth, pugs in the time of 258

Hogg, Mr. Lindsay ...... 288, 309

Holborn Dog Show in 1862 ... 85

Holborn Horse Repository

Show ...................... 30 I

Holborn Show (Maltese at)

in $1862 \ldots \ldots \ldots \ldots \ldots \ldots . . . \ldots . \ldots 319$

Holda (mastiff) ............. 29

Holland, pugs imported from 257

Hope, Mr. P. Beresford ..... 223

Horner, Mrs. ................. 266

Hospice Pluto (St. Bernard) 67

Hospice, St. Bernards at the... 64

Hotspur (mastiff) ............ 29

Houldsworth, Capt. ........... 2 I 4

Houlker, Mrs. C. ............ 266

Hugh (Maltese) .............. 319

Hutchinson, Colonel .......... 170

Hutchinson on the sheepdog... I I 2

Hurst, Mr. F................. I I 2

Hutton, Mr. E. ............... I4I

Hyllus (King Charles) ....... 292

"Idstone," ...........42, I94, 253

Inge, Lieut.-Col. ............ 85

Invincible (bob-tailed sheepdog) ........................ I55

Italian Greyhound ............ 335

Jack (Italian greyhound) history of 
Page.
Jack Spratt (black pug) 272, 274 Jacobs, Mr. J.

"Jacks," the 216

Jackson, Mr. A. C. I 55

Jackson, Mr. Cyril 216,223

Jackson (Mr. Cyril) on the bulldog 231

James, Dr. 42,197

James I., King 6

James II. and his spaniels ... 279 Japan, pug brought from 270 Japanese Pugs, giving them saki to keep them small..... 303 Japanese. Spaniel, not a modern introduction

Japanese Spaniel, points for judging ....................... 31 2 Japanese Spaniel, points of ... 309 Japanese Spaniel, proper size 304 Japanese Spaniels ............. 30 I Japanese Spaniels, a distinct breed 307 Japanẹ̦e Spaniels, classes for 307 Japanese Spaniels, colours of 307 Japanẹse .. Spaniels, many varieties in Japan ........... 308 Japanese Spaniels, Japanese opinions on ................... $30 \mathrm{I}$ Japanese Spaniels, Mr. C. F. Grindrod on................. 304 Jardine, Sir William .......... 28 I Jasper (Ruby) 294 Jenkins, Mrs. 293 Jenkins, Mr. H. E............. 288 Joachim, Mr. E. .............. $35^{2}$ Johnnie Norman (collie) ...... I 24 Joyce, Mr. J. H.............. 214 Jubilee Show, June, I 887
Jumbo (Mrs. Forder's King Charles) .................... $z_{93}$ Jumbo (Mrs. Lee's King Charles)...................... 292 Juno (bulldog) ................ 222 Juno (Italian greyhound) ..... 340

Keeper (St. Bernard) ....... 53

Keller, Mr. C................... 30 I Kemp, Mr. C.................. I 76 Kennel Club Show, July I885 90 "Kennel Club Stud Book"

I 73, 287, 327

King Charles Spaniel hunting 28I King Charles Spaniel in the early shows ................ 286 King Charles Spaniel, sagacity of . 282

King Dick (bulldog)..... 213, 222 Kingdon, Mr. H. D....... 5, 1 I King-Patten, Mr. ............ 48 King Orry (bulldog)..... 209, 223 King Stormy of Homerton (Blenheim) 293

Kitty Cole (bulldog) .......... 223

Knight, Mr................... 294

Krehl, Mr. G. R. ........... 352

"Lady and Spaniels," by Landseer .................... 287 Lady Dinah (Pomeranian) ... 33I Lady in Waiting (Newfoundland) ...................... 96 Lady Mayoress (Newfoundland) ...................... 95 Lamphier, Jacob ..........213, 222 Lamphier, Mr. F. ............ 217 I anding Boy (Dalmatian) ... 196 
Page.

Landseer Newfoundland ...... 98

I andseer's pictures of spaniels 287

Larkfield Shrimp (Italian

greyhound) 340

I.assie (Mr. Ridley's) ....... I4 43

Lassie (smooth collie) ........ I4I

Laureate (King Charles) 292, 293

Laycock's dairy-yard........... 86

Laycock's dairy-yard (dog show) ...................... 44

Lea, Miss 266

Lee, Mrs. $29,95,292$

Lee, Mrs. Cunliffe ............. 94

Leeke, Mrs.

293

Legh, Sir Peers ................ I 2

Leila (St. Bernard) .......... 47

Leo (Newfoundland) ........... 88

L.eo V. (Newfoundland) ..... 97

Leonidas (bulldog)............. 223

Levey, Mr. A................ I 77

Lienhardt, M. Fritz

Life-saving by a Newfoundland

Linton, Mr. R. T. ........ 266, 288

"Lion dog of Malta" ....... 3I 7

Little Gem (King Charles) ... 293

Little Snow (Pomeranian) ... 327

Llangollen trials (collies) ...... I 125

Lloyd, Mr. Edward .......... I47

Lobengula's. (Italian greyhound) 343

I ocke, Dr. I 53

Lola (Blenheim) 293

Londonderry, Lord 273

Lord. Bute (St. Bernard) ..... 52

Loris (black pug) ............ 276

Lort, Mr. W.

I 14

Loup-Loup

[Vor. II.]
Lukey, Mr. H. V.

Page.

Lyme Hall mastiffs .......... Io

Lynn, Mrs. Gordon .......... 330

Lyribel (poodle) .............. I 77

Lyris (poodle) ............. 76 , I 80

Macdona, Mr................ 44

McDonald, Mr. W. ..... 319, 338

Mackenzie's (Miss H. M.)

Italian greyhounds .......... 340

Madame de Poncette (poodle) I 7 I

Maggie Lauder (bulldog)..... 222

Mahdi (black pug) ............ 272

Maltese, the.................. $3 \mathrm{I} 3$

Maltese, Aldrovandus on the.. 3 I 6

Maltese, as a companion ...... 318

Maltese, characteristics of..... 32 I

Maltese, colours in the seventeenth century ................ 3 15

Maltese, difficulty in keeping them in order 320

Maltese, "faking," in times gone by .................... 316

Maltese, method of keeping them small .................. 317

Maltese, points for judging \& 322

Maltese, Sir Edwin Landseer's painting of

Maltese, the oldest of toy dogs 313

Mandarin pug .................. 303

Mandeville, Mr. W. ..... 286, 319

Mansfield, Mr. T. E..... 87, 90

Mansfield's (Mr. T. E.) kennel of Newfoundlands

Mapplebeck, Mr. Howard 88, I 42

Marco (description of the Queen's Pomeranian) ...... 328

Marengo (St. Bernard)........ 53

B B 
Page.

Marlborough Blenheims ..... 286

Marlborough, Duchess of ..... 286

Marples, Mr. T. 309, 328

Marquis of Gaillerdain (poodle) I 7 I

Master Jumbo (Newfoundland)

Mastiff, the

Mastiff, characteristics of ......

Mastiff classes, decadence of ..

Mastiff Club's general description of dogs

Mastiff Club, Old English ...

Mastiff Club, points for judging

Mastiff, Crown Prince, strain of

Mastiff, deterioration of.........

Mastiff fighting a lion

Mastiff, noteworthy dogs ......

Mastiff, origin of.................

Mastiff, origin of Mr. Lukey's

Mastiff, the, in ancient times..

Mastiffs at Chatsworth ....

Mastiffs at Lyme Hall .........

Mastiffs at 'Trentham...........

Mastiffs, a breeder and exhibitor's opinion 23 to 32

Mastiffs, cropped

Mastiffs, development of under-jaw......

Mastiffs, good specimens ......

Matthews, Mrs.

Maud (collie)

Maule, Mr. H.

Max (St. Bernard)

Mayhew, Mrs.

Mayor of Newport (bob-tailed sheepdog)

May Queen II . (Blenheim), 293, 294

May Queen (King Charles)... 292
96

I

21

25

$3^{2}$

32

36

2

I

6

30

2

14

3

I3

10

13

I 4

27

23

96

I 16

266

$7 \mathrm{I}$

266

4

M'Donald, Mr. W Page.

Meg (bulldog).................. 222

Megson, Mr. A. H. ..... II 7, I4I

Melita, uncertainty as to which island is meant ............. 314

Melody (smooth collie) ........ I4 I

Menthon (St. Bernard)........ 46

Mercer, Mr. H. ................ 196

Metchley Wonder (collie) I I 8, I24

Michael the Archangel (bulldog)

222

Minerva (King Charles) ..... 293

Ming Seng (Japanese spaniel) 309

Minting (mastiff) ............ 29

Minton, Mr. A. .............. 85

Mischief (bulldog) ............ 223

Mistress of the Robes (Newfoundland) .................. 96

Moll, Mr. R. W................. 88

Molly (Italian greyhound) $\ldots 338$

Molossus, the ................. 5

Monarch (bulldog)........214, 2 I6

Monarque (St. Bernard) ... 45, 56

Monk, Hon. Mrs. Bligh... 266, 319

Monk (St. Bernard) .......... 43

Monkey Brand (bulldog) ..... 223

Mont Blanc (panorama) ..... 4I

Moore, Mr. B. W. ............ 352

Morris, Mr. J................. 223

Morrison, Mr. .................. 260

" Mortivals," Miss ........ 272, 274

"Mortivals" (Miss) description of the black pug ........ 275

Mother Bunch (Prince Charles) 294

Mozart (Prince Charles) ..... 293

Muller, M. Seiler ............ 69

Murchison, Mr. J. H. ........ 46

Murrell, Mr. G. R. ......... 209 
Page.

Nap II. (black pug) .......... 274

“Naturalist's Library"......... I64

Nelson I. (Newfoundland) 94, 95

Nellie II. (bob-tailed sheepdog) 152

Nettleship, painting of mastiff by

Newfoundland as a companion

Newfoundland (black), description of

Newfoundland Club

Newfoundland Club's description of Newfoundlands IOI

Newfoundland Kennels of the present day 94

Newfoundland, points of ...... 104

Newfoundland, swimming powers of the .................

Newfoundland, the, as a life saver

Newfoundland, the, as a show dog

Newfoundlands a century ago

Newfoundlands as beasts of burden

Newfoundlands at Birmingham in 1860

Newfoundlands at the shows

Newfoundlands in Newfoundland

Newfoundlands, owners of good specimens

Newfoundlands, rearing

Newfoundlands, the Landseer

Nichols, Mr. E. ... 21, 88, 94,

Nigger (black pug)

Nigger (Newfoundland)

Norfolk, a Duke of, and his spaniels
Normanhurst Nap (black pug) 274

Nunn, Mr. J. ..................... 266

"Old Bushman" .............. 83

Old English Sheepdog Club points .................. 156, 160

Oliver, Mr. D. S. ....... 214, 216

Olivette (King Charles) ...... 293

Orlando (mastiff) ............. 29

Orme, Harry ................... 215

Ormskirk Charlie (collie)...... I25

Ormskirk Golddust (collie) ... I I 8

Ormskirk Memoir (collie) ... I I 8

Ormskirk Ormond (collie) ... I I 8

Oswell, Jesse ................... 222

Paley, Mr. A. E. ............. 196

Parbold Phyllis (collie) ......... I 20

Paterson, Mr. W. ............. 97

"Patient Griselda" (picture) I65

Patten, Col. Wilson ........... I3

Paymaster (King Charles) ... 293

Pearce, Rev. T. ............... 253

Pebody, Mr. H................ 223

"Peking " pugs ................ 272

Pekin pug carried in the sleeve 302

Pekin pugs, description of ... 302

Percival, Mr. ................. 213

Pestell, Mrs. ................... 293

Piermaster (Newfoundland) 97

Piggin, Mr. R. S. .............. I25

Pintsch, der Kleine ........... I67

Pirate King (Newfoundland) 97

Plinlimmon (St. Bernard) ... 47

"Plum-pudding" dog, the ... 197

Poll (bulldog) ................... 222

Pollux (St. Bernard) ........... 7 I

Pomeranian, the.............. 322 
Page.

Pomeranian as a housedog ... 325

Pomeranian, description of $\ldots 324$

Pomeranian, club points and

description

Pomeranians, black 327

Pomeranians, fawn, or fawn and white, chocolate ... 327, 330, 33I

Pomeranians, toy .............. 327

Pomeranians, white ........... 325

Pompey (Blenheim) .......... 593

"Pomyoleanian Dog," a ..... 326

Poodle, anecdotes of..... I 70, I 75

Poodle as a companion ......... I 74

Poodle at the battle of Castella 175

Poodle Club, the............... I 173

Poodle, the corded.............. 176

Poodle, corded variety of ...... I 80

Poodle, necessary attention to coat of ...................... I 78

Poodle, points of white ........ I90

Poodle, points of black ......... I 88

Poodle, probable origin of...... 165

Poodle taught to play tricks... I 70

Poodle, time for clipping ..... 179

Poodle, the ..................... I6I

Poodle, the, as a retriever..... 169

Poodle, the Russian ........... I6 I

Poodle, varieties of............. I 162

Poodle "wool" ................. I 83

Poodles, trimming ............. I 76

Portuguese pugs ................ 302

Pratt, Mr. C. A................ 5I

Preston (Lancashire) Show in

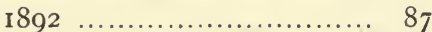

Preston Show of $\mathrm{I} 892 \ldots \ldots \ldots \ldots$ 9I

Price, Mr. R. J. Lloyd, 146, 197, 222

Prim of Nateby (collie).
Prince Battenberg (St. Ber-

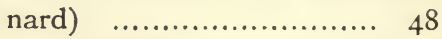

Prince (Blenheim) ............ 293

Prince Charles Spaniels ..... 287

Princess Florence (St. Bernard) $\ldots \ldots \ldots \ldots \ldots \ldots \ldots \ldots, \quad 52$

Prince IV. (Dalmatian) ..... 196 Prince Lily White (Maltese) 320

Prince of Orange (Pomeranian) ..................... 330

Prince of Teddington (Prince Charles) .................... 293

Prince of Wales, H.R.H..... 323

Proctor, Mr. T. ................ 266

Procurator Cynegii ........... 3

Pudel, der Gross ............. I 65

Pudel, der Kleine ............. I67

Pudel, der Mittlere ........... 166

Pudel, der Schaf................ I68

Pudel, der Schnür ............. I68

Pug as a companion ........... 263

Pug as a lady's pet............. 264

Pug, a very sensible ........... 265

Pug, black (in Black and White) ...................... 27 I

Pug breeders ................... 266

Pug, Buffon on the ............ 257

Pug classes at the shows ..... 262

Pug, cutting the ears of the ... 253

Pug, descent not known ..... 256

Pug, descriptions of the black

275,277

Pug Dog Club description of

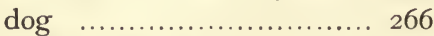

Pug, doubtful origin of theblack 270

Pug drawn by Reinagle ..... 255

Pug in the "Sportsman's cabinet " 
Page.

Pug saving a Dutch prince ... 258 Pug, supposed place of origin 254 Pug, the 253

Pug, the Black 269

Pug, what it should be like ... 263 Pugs, Chinese ................. 27 I

Pugs, first appearance of the black, at shows 273

Pugs in the time of William III. 258

Pugs imported from Holland 257 Pugs, Lady Brassey's ........ 269

Pugs, Lady Willoughby de Eresby's 259

Pugs, points of 268

Punch (bulldog) 223

Pothecary, Mr. W. M

Powers, Mr. John I 42

Pyrenean guard dog I07

Queen Bee (Pomeranian)..... 33 I

Queen Charlotte's pugs........ 260

Queen Mab (bulldog) ........ 223

Queen of the Toys (King Charles) 293

Rae and Parsons, Messrs. ... II 9 Ralli, Mr. C. C. ................. 96 Ralph, Mr. H. I 24 Raper, Mr. George ..... 217, 223 Rector (St. Bernard) 49

Rees, Mr. T. E. I 55

Reick, Mr. W.

52

Reinagle IO9

Reinagle's drawing of the Dalmatian I95

Reinagle's drawing of the pug 255 Reinagle's picture of sheepdog 146 Rice, Mr. C. C.
Rich, Miss .................. 97

Richardson on toy spaniels $\ldots 282$

Rigg, Mr. John .............. I09

Robinson, Miss M. D. ........ 272

Romanie (bulldog)............ 222

Rome, mastiffs taken to ..... 3

Rosa (bulldog) ............... 2 I 2

Rosebud (Newfoundland) ... 99

Royal Rogue (bulldog) ........ 24I

Royle, Mr. J. ................ 49

Ruby Princess (Ruby) ........ 294

Ruby Princess (red spaniel)... 288

Ruby Spaniels.................. 287

Ruby Spaniel, breeding, the... 289

Ruby Spaniels, the best strains

of ............................ 294

Ruling Passion (bulldog) 223, 24I

Rush (bulldog) ............... 222

Rustic King (bulldog) ........ 223

Rustic Model (bulldog)........ 223

Rutland (collie) .............. I I 7

Sadler's Wells Theatre, performing dogs at ............. 172

St. Bernard breeders........... 50

St. Bernard Club .............. 47

St. Bernard Club's description of St. Bernard........... 75

St. Bernard, Landseer's picture of ....................... 40

St. Bernards of $1893 \ldots \ldots .53,54$

St. Bernard, points of ....... 77

St. Bernard puppy, instinct of $4 \mathrm{I}$

St. Bernard still used for finding bodies 74

St. Bernard, the .............. 37

St. Bernard, the first specimen in England 
St. Bernards as beasts of burden

St. Bernards at the Hospice... 64

St. Bernards in Switzerland

(Mr. J. F. Smith's account)

St. John, Mr. Charles, on the bulldog

Saleni (bulldog) 225

(bullog.... 223

Sally Scattercash (bulldog) ... 216

Samoyede dog................. 323

Sancho Panza (bulldog) ...... 2 I4

Sanguinetti, Mr. H. .......... 177

Sans Peur (St. Bernard) ..... 49

Sappho (Italian greyhound)... 340

Schatzel (Pomeranian) ........ 33 I

Save (St. Bernard) .......... 49

Scamp (Prince Charles) ..... 294

Schipperke, character of the... 348

Schipperke Club Shows at the Aquarium................... 352

Schipperke, the points for judging ....................... $35^{\mathrm{I}}$

Schipperke, English Club's description and points ..... 349

Schipperke, origin of name $\ldots 347$

Schipperke, the, at home ..... 347

Schumacher, Mr. H........... 60

Scotland, old-fashioned sheepdogs in ....................... 146

Scotland, sheepdogs in ........ I09

Scott, John .................... 28 I

Searelle, Mr. Luscombe ..... 343

Sears, Mr. E. B................ $5^{\mathrm{I}}$

Sefton Hero (collie) ........... I2I

Sellon, Mr. ..................... 223

Shamrock (collie) ............. II 6

Shaw's (Jemmy) bulldogs...... 21 3

Sheepdog, anecdotes of the, II I, $15^{\circ}$
Page.

Sheepdog, coat of I5I

Sheepdog, colours of the old

English 152

Sheepdog, old English, Dr.

Edwardes-Ker on the ...... I48

Sheepdog, Hutchinson on ...... I I 2

Sheepdog in Thibet .......... I08

Sheepdog, old English or bob-

tailed...................... I45, I4 8

Sheepdog, points of bob-tailed ${ }^{5} 6$

Sheepdog, the smooth-coated. I 39

Sheepdog, unlicensed ........ I I

Sheepdogs, anecdotes of old

English ...................... $15^{\circ}$

Sheepdogs, an old drover's

opinion of ................... 153

Sheepdogs as guards .......... 107

Sheepdogs at church ........... I I

Sheepdogs bred in Suffolk ... 151

Sheepdogs in Scotland ........ Io9

Sheepdogs, tailless ............. 147

Sheffield, Mr. W. L. ........... 266

Shefford strain of St. Bernards 46

Shirley, Mr. S. E. ........ I66, 214

Siegmund, Dr. .............. 72

Simplon Hospice, dogs at

the ............................ 69

Singer, Mr. W. H............ 352

Sion, the convent of, defended by dogs ..................... 39

Sir Anthony (bulldog) ........ 214

Sir Bedivere (St. Bernard) ... $5^{\circ}$

Sir Caradoc (bob-tailed sheepdog) ....................... 154

Sir Cavendish (bob-tailed sheepdog ................... $15^{2}$

Sir Guy (bob-tailed sheepdog) I5I Sir Hereward (St. Bernard)... 54 
Page,

Sir Tatton (bob-tailed sheepdog)

Sleeve dogs, Japanese I55

Slenderman (bulldog) 302

Smartt, Mr. W. G.

Smith, Mr. J. F.

Smith, Mr. S. W. $49,51,53,59$

Spaniel, the English toy

"Spaniell gentle," the ........ 280

Spaniel, Japanese ............. 301

Spaniels painted by Stubbs ... 285

Specht's painting of St.

Bernards

Spencer, Mr. R.

293

Spitz dog ...................... 323

"Sportsman's Cabinet " .. Io9, I46 I63, I64, I95, 21 2, 255, 282, 324 “Sportsman's Repository" ... 28 I

Spotted Dick (Dalmatian) ... 197

Stead (bulldog)

Steiner, M. 222

Steward, Mr. J. J. 70

Stockdale, Charles I 7 213

" Stonehenge" ..I65, I69, I73, 339

"Stonehenge" on the pug ... 259

Stracathro Ralph (collie)..I20, I24

Stretch, the Messrs. ........... I 8

Stubbs, painting of spaniels ... 285

Summer Palace of Pekin, dogs taken from 303

Sunbeam (King Charles) ..... 293

"Sunbeam," pugs on Lady

Brassey's yacht $27 \mathrm{I}$

Surprise (black pug) 275

Susan (bulldog) 229

Sweet May Blossom I. 293

Sweet May Blossom II......... 293

Swinburne, Mr. T.
Switzerland, Mr. J. F. Smith in

Switzerland, St. Bernard saving life in

Switzerland, the dogs at Mont

St. Bernard ...

Sybil (Newfoundland)

Taunton, Mr. W. K.

Taunton, Mr. W. K., on the

Chow-chow 354

Tell (St. Bernard) ........ 44, 56

Temple, Mr. W. R. H....... $35^{2}$

The Earl (Blenheim) ......... 293

"The Dog," by S. Edwards 2 I 2

Thibet Mastiff.................. I5

Thibetan Sheepdog ........... I08

Thomas, Mrs................ 330

Thomas, Miss V. ........... 309

Thomas, Mr. T. E............ I55

Thompson, Mr. S. J........... 294

Thompson, Mr. J. W. ....... I3

Thomson, Mr. W. W. ....... I4I

Thor (St. Bernard) ......... 57

Thornton, Mr. R.' ........ 47, 125

Tiger (bulldog) .............. 2 I 7

Tiger (mastiff) .............. 2 I

Tiny Tots (Blenheim) ........ 293

"Tobit and his Dog" (picture) ..................... I64

Toro (bulldog), Field description of .................... 2 I9

"Toy Bulldogs" ............... 2 I 5

Toy Spaniel Clubs........ 283, 287

Toy Spaniel Club exhibitions 29I

Toy Spaniels at the Westminster Aquarium ........... 288

Toy Spaniels as pets .......... 294 
Page.

Toy Spaniels, colours of ..... 284 Toy Spaniels, English kinds of 279 Toy Spaniels in the East End of London 29 I

Toy Spaniels, novel use for ... 280 Toy Spaniels, points of the English varieties. 296 Toy Spaniels, points for judging.....

Toy Spaniels, prices of

Trefoil (collie)

Troughear, Mrs.

"Truffle Dog," the

Truffle hunting

Turk (mastiff)...

Tupper, Mr. W.

Turner, Mr. Turret Queen (Ruby spaniel) 294

Turton, Mr. 300 283 I 16 176 I 84 I 85 I 2 286 340 Tye, Mr. Edmund $2 \mathrm{I} 3$ I5O

Verrinder, Mr. T. $2 \mathrm{I} 4,222$

Villatica (dogs)

Venom (bulldog)

8
2 I 4

Wales, H. R. H., the Prince of

Wales, sheepdogs in

Wall Eyes

Wall-eyed Bob (bob-tailed sheepdog)

Wall or "China" Eyes I 55

Walsh, Dr. J. H. ... I I 4, 320, 345

Warner, Mrs. W. H. B.

Wasp (bulldog) $270,293,319$

Watch (St. Bernard)
Watchboy (bob-tailed sheepdog) ......................... I55

"Water Dog," the............. I $6_{3}$

Weager, Mr. .................. I55

Wee Flower (Italian greyhound) 339

Westfield, Mr. T. ............. 266

Westminster Aquarium Toy Dog Show.................... 288

" Whippet," the .............. 337

White's (Ben) kennels ........ 2 I 3

White, Mr. W. ................ I I 5

Wildman, Mr. S. W. ........ 88

William III. brings pugs to England ...................... 257

Willoughby de Eresby, Lady 259

Willoughby pugs ............. 259

Wilson, Mr. T. Newby......... I 66

Windsor Castle, Pomeranians at ........................... 330

Witch (poodle) .............. I 77

Wolf $\operatorname{dog} \ldots \ldots, \ldots \ldots \ldots \ldots \ldots . . . . . . .323$

Woodgate, Mrs............... 294

Woodiwiss, Mr. E. S. ....... 352

Woodiwiss, Mr. I. ............. 352

Woodiwiss, Mr. S. ..... 208, 223

Wynn, Rev. M. B. ..... 3, 5, I3

Yarrow (smooth collie) ........ 14I

Yates, Mr. .................... 293

Youatt's picture of a bulldog 2 I 2

Young Bute (St. Bernard) ... 52

Young Jumbo (King Charles) 293

Young Plato (St. Bernard) ... 70

Zingra II. (Prince Charles) 293

Zoe (Newfoundland) .......... 97 
Advertisements.

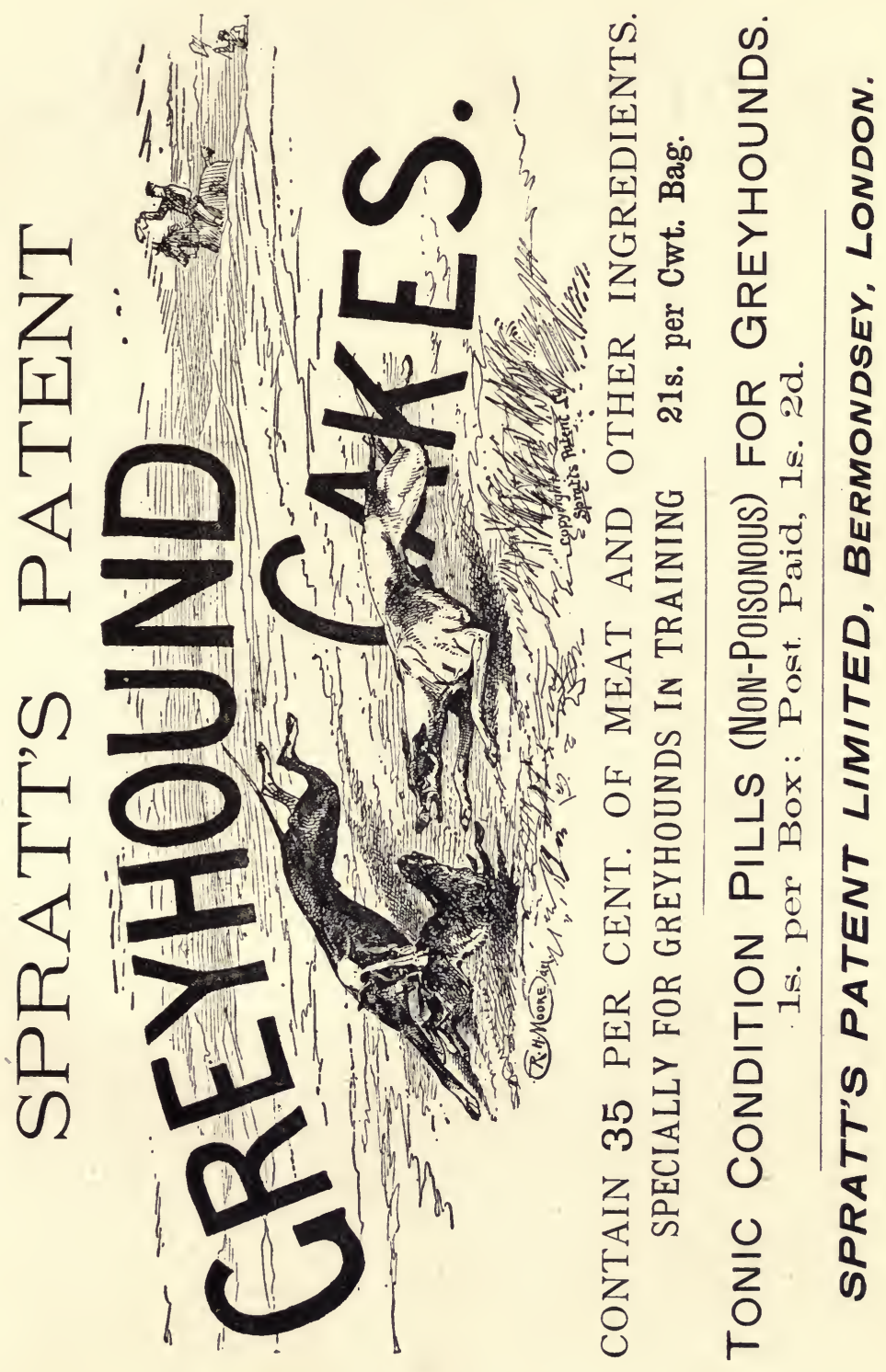


THE ORIGINAL MAKERS OF KENNELS, POULTRY HOUSES, AND APPLIANCES.

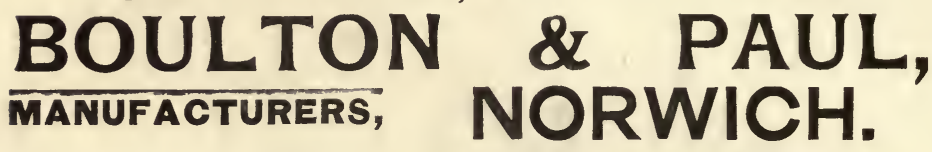

OUR ORIGINAL REGISTERED DOG KENNEL.

Reduced Cash Prices, Carriage Paid, including Registered Sliding Bench :

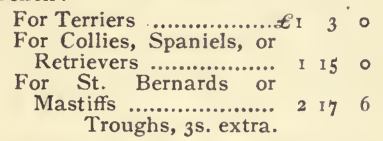

These Kennels are well made, and highly finished. All parts are accessible for cleaning and disinfecting. The sliding bench is an important addition, and adds greatly to the comfort of the dog.

No. 63. DBL. FERRET KENNEL WITH RUNS. No Foot Rot. No Disease.

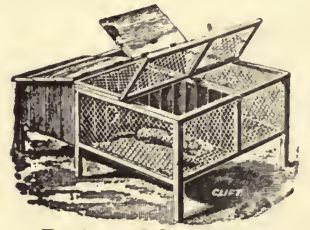

Registered Copyright.

\section{CAST-IRON DOG TROUGHS.} No. 1.

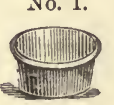

Galvanised. 10in. dia., 2/12in. dia., $3 /-$

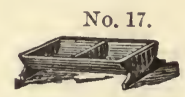

Painted.
$4 \mathrm{ft}$. long, 3ft. wide, 2ft. high, 18in. long ... each $4 \mathrm{~s}$. £1. 15s.; larger size, £2.5s. 24 in. long ... each $5 \mathrm{~s}$.

No. 87. WROUGHT-IRON KENNEL RAILING.

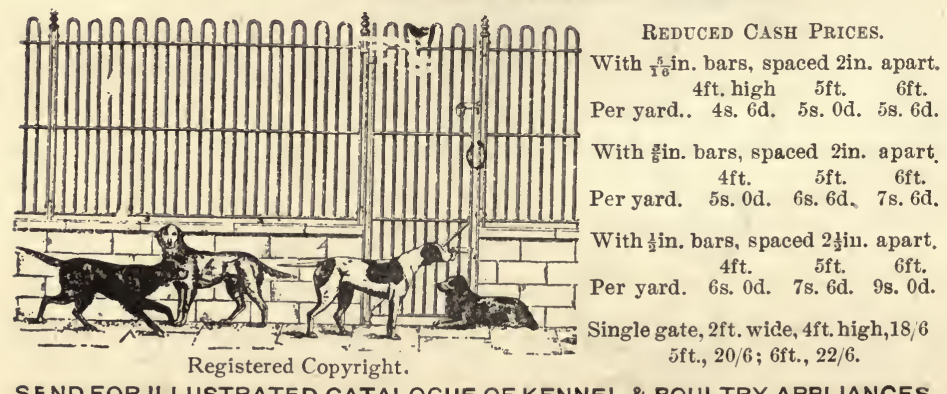

SEND FOR ILLUSTRATED CATALOGUE OF KENNEL \& POULTRY APPLIANCES. BOULTON \& PAUL, NORWICH. 
Advertisements.

\section{SCOTT ADIE,}

LADIES' AND GENTLEMEN'S TAILOR,

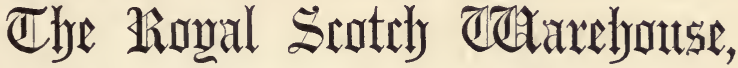

115 \& 115A, REGENT ST., LONDON, W.

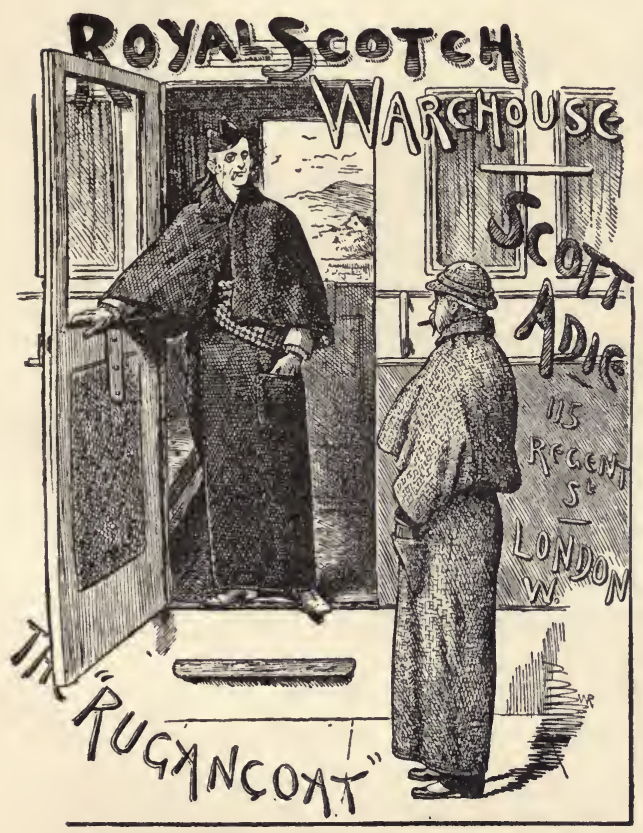

This novel and useful garment is a unique departure from the old-fashioned rug, comprising, as its name indicates, a combined rug and coat; it may be used as either. It will be found useful for Fishing, Deer Stalking, or Driving; it is light and inexpensive. After it has been in use as a rug on a railway journey, and one has to face a five or six miles drive in an open carriage at night, nothing could then be more comforting than the "RUGANCOAT," used as a coat. Every sportsman and tourist should use one, as they are a perfect protection against wind and weather.

\section{SCOTT ADDIE,}

SOLE MANUFACTURER.

Highland Shooting Suits.

Highland Dress Suits. Highland Jewellery.

Inverness Capes. Stalking Capes.

Travelling Ulsters.

RUGS, MAUDS, SHAWLS, AND WRAPS OF EVERY DESCRIPTION. HARRIS AND SHETLAND HOMESPUNS.

HAND-KNIT STOCKINGS AND SOCKS. TARTAN SILK AND RIBBONS.

Gye liowal Srotch Tatarefouse,

REGENT STREET AND VIGO STREET, LONDON, W.

Telegrams : "SCOTT ADIE, LONDON." 


\section{CHAMBERLIN'S PHEASANTS' FO0D,}

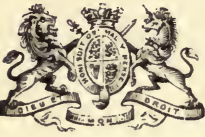
AROMATIC SPANISH MEAL, CAYCAR EXCELSIOR,

DOUBLE-SUPER MEAT GREAVES,

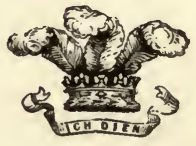

Obtained the only Award for Game Food, PARIS INTERNATIONAL EXHIBITION, 1878.

Bronze Medal, Mannheim, 1880;

Silver Medal, Cleves, 1881; Silver Medal, Antwerp, 1885; Honourable Mention, Paris Exhibition, 1889.

Supplies constantly forwarded to Her Majesty's Royal Parks, H.R.H. the Prince of Wales at Sandringham, and to all the Noblemen and Landed Proprietors in the United Kingdom, France, Germany, Holland, Belgium, Sweden, \&c.

Write for the New Book of Prices, with Treatise on Pheasant Rearing, Free by Post.

\section{E A I Y Y D F, \\ A VOlAtile POWDER.}

The only cure for Gapes in Pheasants and Poultry.

Price 2s. 6d. per tin, Post Free.

\section{JAMES CHAMBERLIN \& SMITH,}

Game, Poultry, and Dog Food Warehouse,

POST OFFICE STREET, NORWICH. 


\section{CHARLES FRAZER'S EXORS., PALACE PLAIN WORKS, NORWICH.}

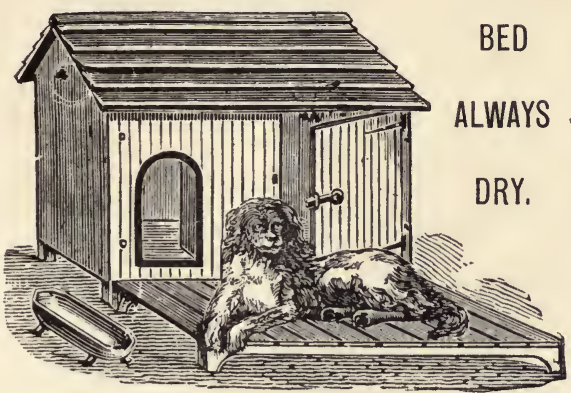

No. 136.

PORTABLE DOG KENNEL AND RUN.

REDUCED CASH PRICESCARRIAGE PAID.

For Terriers (with $5 \mathrm{ft}$. Run and Bench)

For Collies (with $7 \mathrm{ft}$. Run and Bench) ... For Mastiffs (with gft.

Run, all iron, and

Bench)

$£$ s. $d$.

276

$317 \quad 6$ 5176

Wood Floor for Runs, 8s, 6d., 10 s., and 15s., extra.

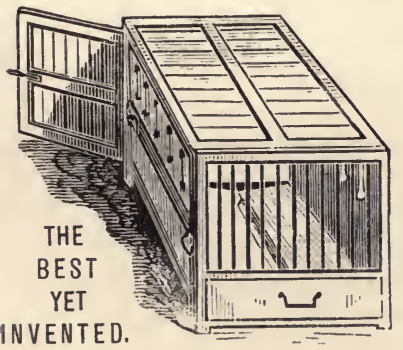

No. 83. PORTABLE DOG KENNEL.

Strongly made of seasoned Red-wood and well finished.

REDUCED CASH PRICES.

Carriage Paid on 40s. value.

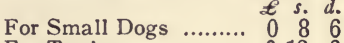
For Terriers ................. 0186

For Collies, Spaniels, \&c. .................... 1150 For Mastiffs, \&c.......... 2100

Outside Platforms for Dog to lay upon, $4 \mathrm{~s},, 5 \mathrm{~s}$, , \& $7 \mathrm{~s}$ 6d,, extra. Food Trough, 3 s.

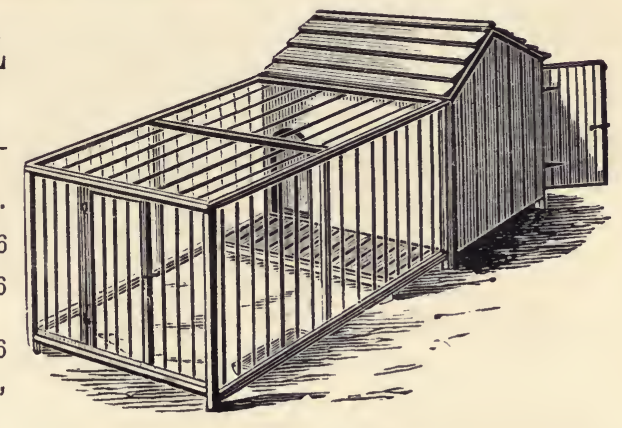

No. 137. NEW TRAVELLING BOX FOR DOGS.

Specially constructed with a view to the Dog's comfort whilst travelling. Improved system of drainage and ventilation.

CASH PRICES-Carriage Paid on 40s, value. LENGTH. WIDTH. HEIGHT. 27 in. by 20 in. by 24 in. ................... 0 . 150

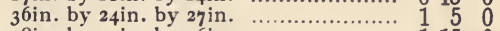

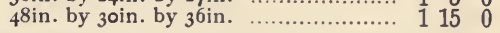

For long journeys a Draiwer is provided, as per illustration, for Food and Water, at 2 s. $6 \mathrm{~d}$., $3 \mathrm{~s} .9 \mathrm{~d}$., and 5 s., extra.

Large Illustrated Catalogue of Conservatories, Greenhouses, Poultry Houses, Dog Kennels, Portable Buildings, Entrance Gates, and all Garden Requisites, Post Free for Six Stamps. 


\section{WILLIAM FORD,}

\section{SPORTING GUN AND RIFLE MAKER,}

\section{PRACTICAL GUN-FITTER AND GUN-BARREL BORER,}

Borer of Five Winning Guns in the London Gun Trials, i875.

Awarded Gold Medals and Gold Cross for Superiority

in Boring Guns and Giving Highest Penetration on Record in i879.

MAKER OF GUNS FOR SOME OF PHE

PRINCIPAL AND MOST SUCCESSFUL PIGEON SHOTS IN ENGLAND, AMERICA, AND AOSTRALIA.

\section{SPECI A L I T I E S :}

FORD'S PIGEON GUN, FOR TRAP OR GAME SHOOTING.

(Hammer or Hammerless.)

FORD'S PATENT EJECTOR GUN.

FORD'S “ECLIPSE" DOUBLE GUN, 28-BORE.

Weight from $4 \mathrm{lb}$. to $5 \mathrm{lb}$. as required. Adapted for use by elderly gentlemen, ladies, and youths requiring a light and effective gun.

FORD'S BALL AND SHOT GUN,

With invisible rifling, for use abroad; a most effective weapon for Big Game.

See letter in Field, with Illustrations, January 2oth, I894.

FORD'S PATENT ADJUSTABLE TRY GUN, FOR ASCERTAINING AND SECURING A PERFECT FIT.

FORD'S PRIVATE SHOOTING GROUNDS.

Replete with every requisite for testing guns, defective aiming, and peculiarities in shooting, and also for TEACHING AND PRACTISING THE ART OF SHOOTING at inanimate birds or live pigeons, under the personal instruction of WILLIAM FORD.

Notices, a day or two previously, of intended visits to the grounds are necessary to avoid disappointment.

Guns converted, rebored, regulated, adjusted, and fitted to every requirement and peculiarity in shooting, and upon the most improved principles.

GUN REPAIRS OF EVERY DESCRIPTION EXECUTED.

EVERY VARIETY OF GUN CASES, IMPLEMENTS, \&C., TO ORDER.

ILLUSTRATED PRICE LISTS, ESTIMATES, AND QUOTATIONS, FREE BY POST UPON APPLICATION.

ECLIPSE WORKS, LOVEDAY STREET, BIRMINGHAM. Telegraphic Address: "Eclipse," Birmingham. 
Advertisements.

\section{THE LIVE STOCK AGENCY.} Established 1887.

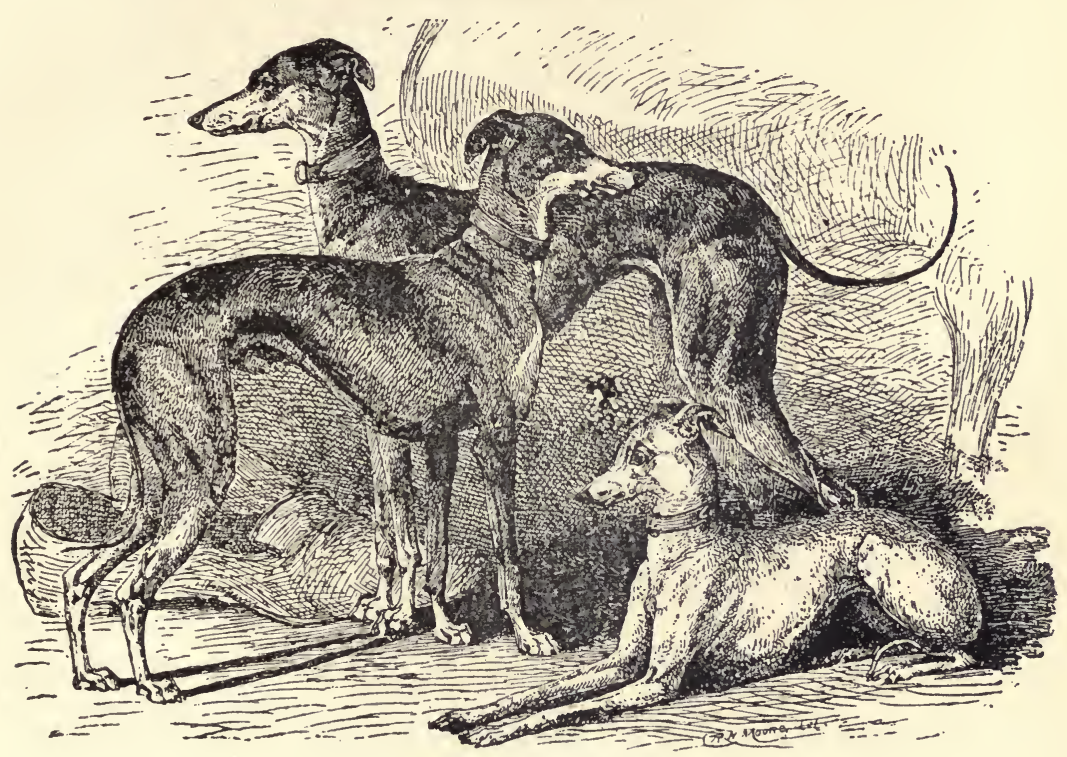

ITALIAN GREYHOUNDS.

Prince Charming, Princess Zeta, and The Lady Grace.

The property of Mrs. F. E. Anstice.

EVERY SPECIES OF ANIMAL OR BIRD, AND EVERY DESCRIPTION OF

PEI, AISO SPOITING DOGS, CATTLE, PONIES, HORSES,

\section{AND}

LIVE STOCK PROCURED AND SHIPPED ABROAD.

\section{Live Stook Sales Attended.}

Address the Manager,

WESTMINSTER CHAMBERS, 3, VICTORIA STREET, LONDON, S.W. BANKERS - THE LONDON JOINT STOCK. 
Advertisements.

Thomas \& Sons Bnickerbocker

Breeches

have stood the

test of many years, and still

hold their own by reason

that they will never be sarpassed for comfort and utility. can be made

in any material, or to match coat.

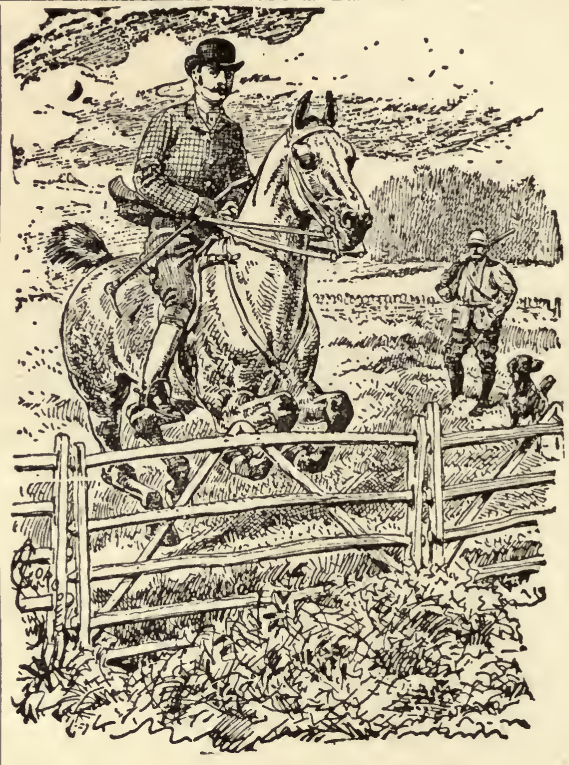

$$
\begin{gathered}
\text { Sporting } \\
\text { Clothes } \\
\text { of every } \\
\text { description } \\
\text { made in a } \\
\text { thoroughly } \\
\text { practical } \\
\text { manner, } \\
\text { including } \\
\text { many } \\
\text { specialities } \\
\text { unobtainable } \\
\text { elsewhere. }
\end{gathered}
$$

THSTIMONIAI.

Vide the "Field," January 10, 1885.

" Shоoting Clothes. - In reply to 'Tartan,' when having shooting clothes made. let me advise him to try THOMAS AND SONS' Knickerbocker Breeches, as advertised in the Field. They form the most comfortable garment for the legs ever invented. Whilst giving the same freedom at the knee that ordinary knickerbockers do, they gire firm protection and warmth below it, Everyone who wears them knows what a nuisance knickerbockers are if one has occasion to ride when having them on. Now, THOMA's way of making them renders them equally comfortable for riding or walking."-OMNıBUs.

hunting, Racing, and Polo Breeches, Perfect in STYLE AND FIT.

Separate Department for Ladies' Riding Habits, d c., dic.

\section{THOMAS \& SONS, SPORTING TAILORS AND BREECHES MAKERS. 32, BROOK STREET, W. (corner of SOUTH MOLTON STREET)}

AND AT 60, CASTLE STREET, LIVERPO0L.

Telegraphic Address: "Sportingly, London." 


\section{Advertisements.}

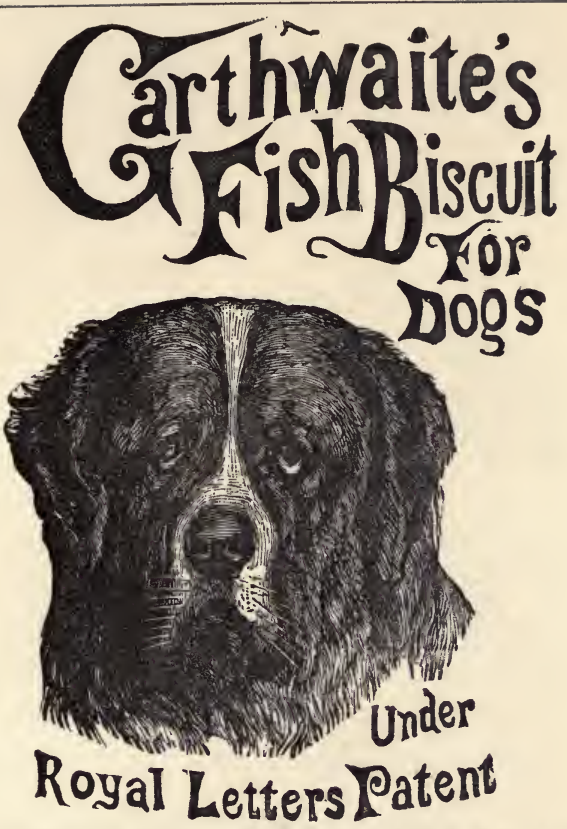

THE ONLY BISCUITS WHICH ALL DOGS LIKE AND EAT READILY. Mr. J. G. HARvex, Huntsman to Her Majesty, writes: "I must say for hounds I would not be without them."

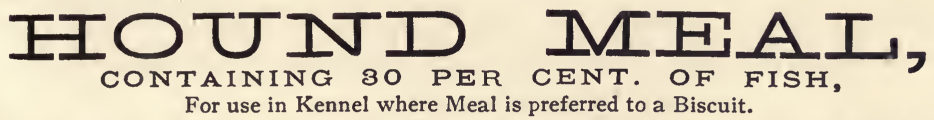

PRICE 17 S. PER CWT., HALF CWT. 9 S.

W. R. TEMPLE, ESQ., WRITING DECEMBER IST, I891, says:-

"I sent six dogs to the late Palace Show, and took one First, three Second, and two Third Prizes. All the dogs were fed entirely upon your Fish Hound Meal."

\section{IMPERIA工 \\ MEAT FIBRE DOG CAKES. WITH VEGETABLES AND BONE MEAL.}

These Biscuits guaranteed free from greaves, and containing a large percentage of Pure American Meat, are the most nutritious and easily digested Meat Biscuits made; they are used with great success in many Kennels alternately with our Garthwaite's Fish Biscuits. Each Cake is stamped "Imperial Meat Fibre," with a Crown in centre.

Price 17s. Per CWT., Half CWT. 9s.

Above prices include Carriage. Special quotations for quantities.

Pamphlet, with particulars and testimonials, post free.

THE FISH BISCUIT CO. LTD., GRIMSBY.

[VoL. II.] 


\section{WESTLEY RICHARDS \& CO. IIMITED.}

\section{PATENT EJECTOR GAME AND PIGEON GUNS.}

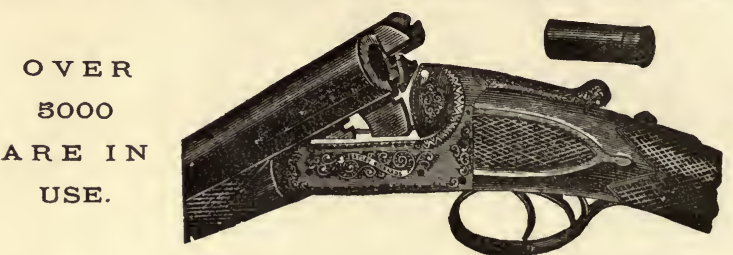

\section{THE}

SHOOTING OF OUR

GUNS AND RIFLES HAS N E V E R BEEN SUR. PASSED.

THE Westley RICHARDS Patent Ejector GUNS and RIFLES obtained the Grand Prix, the highest award of the Paris Exhibition, I889.

ROOK \& RABBIT RIFLES, 250 , 295 , or 300 and ' 360 bores, in all patterns.

178, NEW BOND STREET, LONDON; 12, CORPORATION STREET, BIRMINGHAM.

Established $18 \mathrm{r} 2$.

28 Page Catalogue Sent Free on Application.

\section{BARNARD, BISHOP, AND BARNARDS, LTD.}

\section{MANUFACTURERS OF}

EVERY REQUISITE FOR DOGS, POULTRY, PIGEONS, AND RABBITS, ON TRE MOST APPROVED PRINCIPLES.

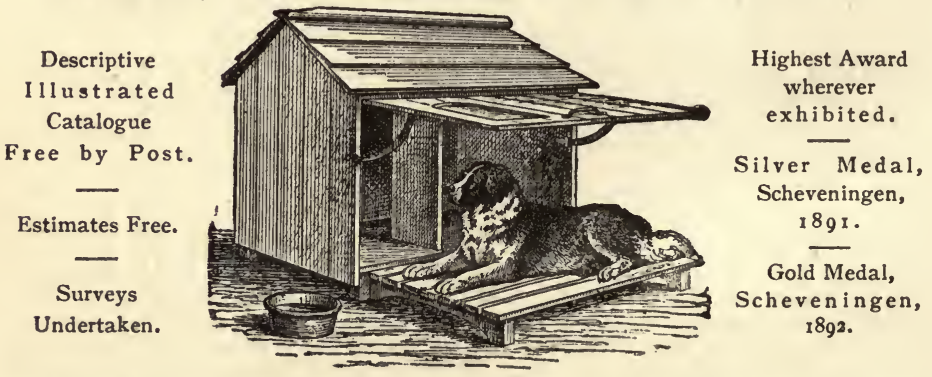

IMPROVED KENNEL, with Lifting Front and Sliding Day Bench, finished in the best style. For Terriers, 27s. 6d.; for Retrievers, \&c., 45s.6d. ; for Mastiffs, \&c., 69s. 6d.; Carriage Paid.

NORFOIK IRON WORIK, NORWICI, AND 95, QUEEN VICTORIA STREET, LONDON, E.C. 


\section{WORMS IN DOGS.}

" $\mathrm{S}$ TONEHENGE," in his celebrated work on the Dog,

says: "Worms are a fertile source of disease in the dog, destroying every year more puppies than dis temper itself."

While the "FIELD" says, concerning distemper: "All treatment, to be successful, must be prefaced by the expulsion of worms."

\section{NALDIRE'S}

\section{WORM POWDERS for DOGS}

Safely remove these pests within one hour, at the same time giving tone to the stomach, and producing first rate condition in dogs.

WORMS

IN A

FOX TERRIER.
"The Cottage, Sandhills, Walsall, March 3 rd, 1887 . "Please send me one of Naldire's Worm Powders. I consider them splendid. I had a fox terrier nearly dead last Sunday, and got one of your powders from a friend, and in fifteen minutes after the dog had it he passed a tapeworm almost 60 feet in length.

"FRANK J. BRAWN."

\section{NALDIRE'S WORM POWDERS ARE SOLD BY ALL CHEMISTS,}

In Packets, 1/-, 2/-, 3/6, and 5/- each, with Full Directions for Use.

\section{FLEAS IN DOGS.

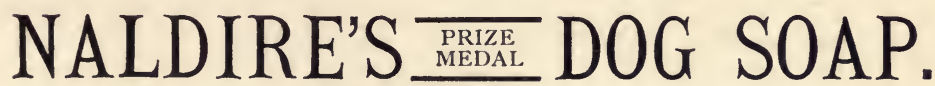
FREE FROM CARBOLIC ACID AND ALL OTHER POISONS.

"Naldire's Soap is harmless to dogs, but fatal to fleas."-FRANK BUCKLAND.

SOLD BY ALL CHEMISTS, PERFUMERS, AND STORES. 


\section{NEWGASTLE GHILLED SHOT.}

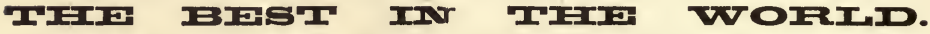

SEE RECORDS OF THE LONDON GUN TRIALS 1875, 1877, 1878, 1879.

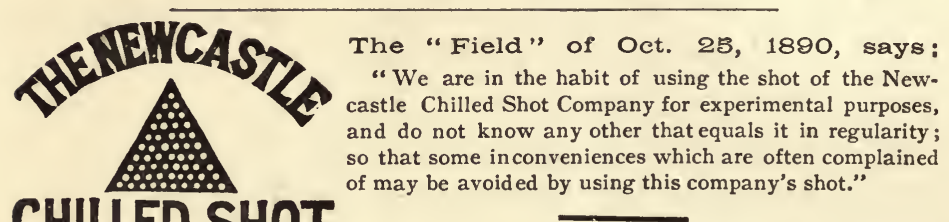

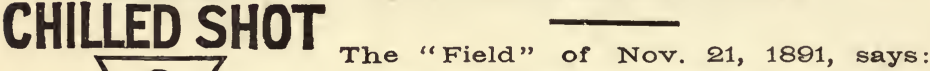

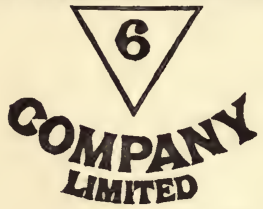

"The use of Newcastle Chilled Shot will not injure gun barrels. We have used it for years, with many thou sands of cartridges."

\section{Beware of Imitations.}

\section{SOLE ADDRESS-GATESHEAD.}

Telegrams : "Chilled, Gateshead."
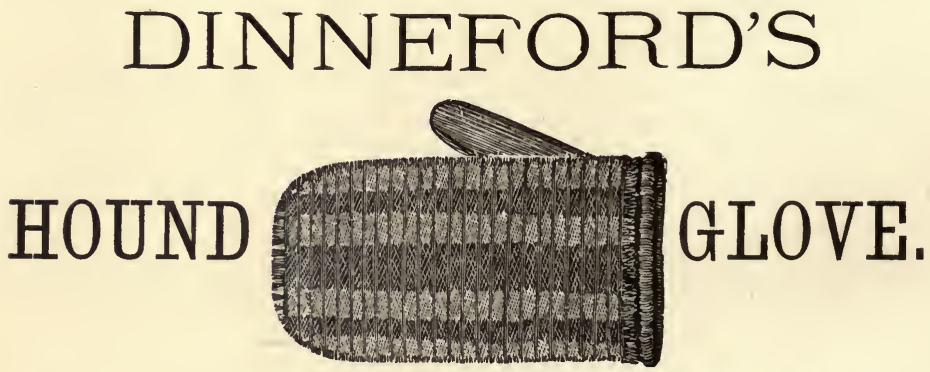

Unrivalled for producing a healthy, sleek, and glossy surface on the coats of Greyhounds, Foxhounds, Harriers, wire-haired, and smooth-coated Dogs.

$$
\text { Price 5s., Free by Post. }
$$

DINNEFORD \& CO., Manufacturers, 180, NEW BOND STREET, LONDON, W. 


\section{DOG PILLS.}

\section{HIND'S ALTERATIVE PILLS}

FOR PREVENTING DISTEMPER

\section{AND GETTING DOGS INTO SHOW CONDITION ARE UNRIVALLED.}

W. W. Tном pson, Esq., writes: "I consider your Pills for getting dogs into condition most excellent. I have given them a good trial."

R. HOOD-WRIGHT, Esq., writes : " 1 have never had a single case of distemper amongst my Deerhounds since I used them."

In addition to the above, the following, amongst a long list of well-known gentlemen, have signified their entire approval of them: H. Ralph, Esq., T. Easton, Esq., G. Cartmel, Esq., R. B. Lee, Esq.

SOLD IN BOXES, Is. Id., 2s. 6d., and 5s., Post Free.

WORM POWDERS, A SAFE AND CHEAP VERMIFUGE FOR DOGS, Sold in Packets, free by Post, 1s. 1d., by

HIND, CHEMIST, KENDAL.

TRY MY PASTE FOR DESTROYING FLEAS, TICKS, \&c. In Tins, 9d., is. 3d., and 2 s. 3 d., post free.

\section{WORKS PUBLISHED BY HORACE COX,}

\section{Gipsy Tents, and How to Use Them.}

A Handbook for Amateur Gipsies. By G. R. Lowndes. Crown 8 vo., profusely illustrated, price 2 s. 6 d., by post 2s. $9 \mathrm{~d}$.

Contents.-Camping as a Fine Art; Of the Tent Ordinary; The Gipsy Tent Elementary; The Gipsy Tent Developed; The Baulk; Pitching and Striking; Of Camp Fires; Of a Permanent Camp; A Boating Camp; Of Vans; Pack Saddles; Cooking Utensils, \&c.; Bedding and Clothes; Of Joys and Sorrows; Addenda; Index.

List of Plates. - Amateur Gipsies; A Quiet Backwater; At Shiplake ; Interior of a Gipsy Tent; Our First Tour; On the Way to the Farm; An Anxious Question; In the Land o' Cakes; A Visitor; On the Road; Forerunners of the Sunday Crowd; A Critical Moment.

"Field" Office, Windsor House, Bream's Buildings, E.C. 


\section{Yacht Architecture.}

By Dixon Kemp, Associate of the Institute of Naval Architects and Member of the Council. This work enters into the whole subject of the laws which govern the resistance of bodies moving in water, and the influence a wave form of body and wave lines have upon such resistance. It also deals comprehensively with the subject of Steam Propulsion as applied to yachts. An easy System for Designing is provided, and every necessary calculation is explained in detail. The latter part of the work is devoted to Yacht Building, and engravings are given of every detail of construction and fitting, including laying off, taking bevels, \&c. The List of Plates (exclusive of over thirty devoted to the elucidation of the text, and nearly two hundred woodcuts) exceeds fifty, and comprises the Lines of some of the most celebrated Yachts afloat by the most successful builders and designers. SEcond Edition. Super-royal 8vo., price £2 2s., by post $£ 2$ 3s.

\section{OPINIONS OF THE PRESS.}

"Mr. Horace Cox, London, has published a new edition of Mr. Dixon Kemp's treatise on 'Yacht Architecture.' The book, which is an admirable exposition of the whole science and art of designing and building yachts, has been revised, partly re-written, and much enlarged in this edition. No small part of the new matter consists of new diagrams and plates. The work has from the first been exceptionally r.ch in this practical help to builders. It now iontains probably the most complete collection of designs of this kind that have been brought together into a book. The text takes notice of all recent improvements in building and of new developments in the scientific theories of propulsion by steam and sail. The new edition, on the whole, will keep the book in its place as an indispensable work of reference and instruction for builders." - The Scotsman, April 20, 1891.

"One great merit in the second edition of Mr. Kemp's 'Yacht Architecture' is that it is in every part written up to time. The chapter on stability is in every respect highly satisfactory, technical enough to satisfy the specialist, and yet plain enough to inform the man of ordinary intelligence. So also in regard to centre-boards. When the first edition was published, few English yachtsmen knew or car $d$ d as to what was meant by the term; but the racing for the "America" Cup, and especially the running of the Thistle with the Volunteer in the autumn of $\mathbf{1 8 8 7}$, has created quite a new interest in centre-boards, and the subject is discussed in this edition in a manner at once simple and lucid. The chapters devoted to steam yachts are among the most satisfactory in the book."-Daily Graphic, A pril 29, $189 \mathrm{I}$.

"'Yacht Architecture,' by Mr. Dixon Kemp, has been re-issued from the Field office, partly re-written, revised, and enlarged. .... A series of new plates of the lines of the most modern craft take the place of those accompanying the first edition of the work. By means of these illustrations the respective British and American types of yachts may be compared, and the amateur may learn the practice of the best builders upon both sides of the Atlantic."-Daily Telegraph, May 19, 1891.

"A handsome and portly volume, which ought to find a place in the library of every yachtsman." - Glasgow Herald, April 23, 1891.

"Mr. Dixon Kemp's volume supplies yachtsmen with every possible information in a plain practical manner, and, furthermore, to the most experienced theorist it will be found of almost constant use for reference in both theoretical and practical knowledge."-Irish Times, A pril $28,1891$.

"Field" Office, Windsor House, Bream's Buildings, E.C. 


\section{A Manual of Yacht and Boat Sailing.}

By Dixon Kemp, Associate of the Institute of Naval Architects and Member of the Council, Author of "Yacht Designing" and "Yacht Architecture." This edition has been largely re-written, and contains a great number of new subjects, and the lines of many boats never before published, the total number of Plates exceeding Ioo, besides more than 350 woodcuts in the text. Seventh Edition. Super-royal 8vo., price $25 \mathrm{~s}$., or by post $26 \mathrm{~s}$. (The Lords Commissioners of the Admiralty have ordered this work to be supplied to the Libraries of the ships of the Royal Navy.)

Contents.-Selecting a Yacht; Examination of the Yacht; Building a Yacht; The Equipment of the Yacht; Seamanship; The Management of Open Boats; The General Management of a Yacht; The Rules of the Yacht Racing Association; Yacht Racing; Handling a Yacht in a Match ; Centre-Board Boats; Centre-Board Boats for Rowing and Sailing; Sails for Centre-Board Boats; Small Centre-Board Yachts; Mersey Sailing Boats; Clyde Sailing Boats; Belfast Lough Boats; Dublin Bay, Kingstown Boats; Cork Harbour Boats; Itchen Boats; Falmouth Quay Punts; Thames Bawley Boats; Lake Windermere Yachts; Yachts of the Norfolk Broads; Small Yachts and Boats of Y.R.A. Rating; Single-handed Cruisers; Types of Sailing Vessels; Double Boats; Steam Yachting; Ice Yachting; Canoeing; Amateur Canoe Building (in America).

Appendix contains complete instructions as to Practical Boat Building. This section is arranged alphabetically in the form of a dictionary, and embodies a variety of information connected with Yachts, Boats, the customs of the sea, laws relating to seamen, nautical terms, and in fact everything which might be expected in a nautical cyclopædia. Full instruction is given as to the building and management of every boat described.

\section{British and Irish Salmonidær.}

By Francis Day, C.I.E., F.L.S., and F.Z.S. This work is an exhaustive treatise on the Salmonidx of the British Islands, and will be found equally valuable to the Angler, the Fish Culturist, and the Scientific Icthyologist. In one volume, imperial 8vo., cloth, price $£_{I}$ Is., by post $£_{\mathrm{I}}$ Is. $6 \mathrm{~d}$. With twelve coloured plates and many woodcuts. A few copies to be had, beautifully bound in whole calf, full gilt, price 35 s. 


\section{Pheasants :}

Their Natural History and Practical Management. By W. B. Tegetmeier, F.Z.S. (Member of the British Ornithologists' Union), Author of "The Natural History of the Cranes," \&c. Illustrated with numerous full-page engravings drawn from life by T. W. Wood. Second Edition, greatly enlarged. Royal 4to., bevelled boards, gilt edges, price $15 \mathrm{~s}$., by post $\mathrm{I}_{5} \mathrm{~s} .9 \mathrm{~d}$.

NOTICES OF THE SECOND EDITION.

From Yarrell's "British Birds," fourth edition.- "For further details, as well as for instructions as to the management of pheasants, both in the covert and the aviary, and the disorders to which they are liable, the reader is referred to Mr. Tegetmeier's excellent work, to which the editor is under great obligations."

From Nature.-" The work will be found invaluable to anyone projecting the cultivation of pheasants either in the covert or the aviary."

From the Daily Telegraph. - "Both in its descriptive and in its practical aspects the treatise is admirable."

From the Spectator.-" A valuable monograph."

From the Pall Mall Gazette.-" This new and sumptuous edition contains so large an amount of fresh matter that it may be regarded practically as another work. In its own way it is quite exhaustive. . In the technical details of rearing and preservation, Mr. Tegetmeier will be found a thoroughly trustworthy and scientific guide."

\section{Essays on Sport and Natural History.}

By J. E. Harting. 8vo., pp. 463, with thirty-two illustrations, price ios. 6 d., by post i is.

Contents.-Shooting; Hawking; Fishing; Training Hawks; Lark Mirrors; Plover Catching; Fishing with Cormorants; Decoys; the Irish Wolfhound; the Badger; Wild Turkeys; the Great Bustard; Seals; Wild Swans, \&c.

Thirty-eighth Essays: concluding with Practical Hints on Bird Preserving for the use of Travellers and Collectors.

\section{Hints on the Management of Hawks.}

By J. E. Harting, Author of "A Handbook of British Birds," "Essays on Sport and Natural History." In demy 8 vo., price 3 s. 6 d., by post 3 s. 9 d.

"Field" Office, Windsor House, Bream's Buildings, E.C. 


\section{The Collie or Sheepdog.}

A History and Description of the Collie or Sheepdog, in his British Varieties. By Rawdon B. LeE, Kennel Editor of the "Field," and Author of "The Fox Terrier." Demy 8vo., printed on plate paper, with illustrations by Arthur Wardle, price 3s. 6d., by post 35. I Id. A few copies on large paper, price Ios. 6d., by post I Is.

“' The Collie or Sheepdog' is a sufficiently well known and popular animal to render a history and description of the British varieties of the species a welcome addition to the library of the dog fancier. Mr. Rawdon Lee publishes a volume dealing with the subject, which is issued by. Mr. Horace Cox at the Field Office. Much information as to the breeding and points of the dog is given, together with an exhaustive account of competitive trials, of which the writer has a large experience. It is needless to say that anecdotes as to the sagacity of the collie are numerous." -Morning Post, July 23,1890 .

"The subject of the present volume is the ever-popular collie, which is treated in the same attractive manner as the previous work. It breathes of the hills, and living as Mr. Lee did for so many years in Westmoreland, he can transfer to his pages many interesting reminiscences of the sheepdog as a worker, comparing him with the collie in the more refined period of his life. The initial chapters are excellent reading, and the author has displayed considerable skill in them, bringing as he does the testimonies of poets and of painters, of shepherds and of breeders."-Fancier's Gaxette, July I8, I 890 .

"Mr. Lee's book, filled as it is with accurate information as to the various strains and valuable suggestions as to their rearing and management, is a manual which to all collie owners or collie breeders is likely to be highly serviceable."-Saturday Review, May 16, $189 \mathrm{I}$.

\section{The Dogs of the British Islands:}

Being a Series of Articles on the Points of their Various Breeds; and the Treatment of the Diseases to which they are Subject. By the late J. H. WALSH, "Stonehenge," Editor of the "Field" (with the aid of several experienced Breeders). Fifth Edition. Re-written, with additions, and new full-page engravings. In one volume, bevelled boards, gilt edges, price i5s., by post I 5 s. $9 \mathrm{~d}$.

Contents-General Management: Management of Dogs in Health; Drugs Commonly Used for the Diseases of Dogs, and their Modes of Administration; the Ordinary Diseases of the Dog and their Treatment; Judging at Dog Shows and Field Trials. Sporting Dogs: Dogs Used with the Gun; Hounds and their Allies. Non-Sporting Dogs: Watch Dogs; Sheep and Cattle Dogs; Terriers (other than Fox and Toy); Toy Dogs.

" This edition of 'The Dogs of the British Islands' contains so much fresh matter that it may be almost considered a new work. To breeders and lovers of dogs the book is an invaluable oneHere are all the discussions upon moot points of breed, strain, colour, size, and form, which have taken place in the columns of the Field since 1865; here the law for judging dogs, and the number of marks to be awarded for the various points are clearly laid down: here the specialities of the most celebrated sires of various species are talked over, and the history, so to speak, of each breed of dog is given. To this are added directions for the management and treatment of dogs in health and in sickness. Altogether it is a vade mecum for the dog fancier and breeder."-Evening Standard.

"Field" Office, Windsor House, Bream's Buildings, E.C. [Vor. II.] 


\section{The Modern Sportsman's Gun and Rifle.}

Including Game and Wildfowl Guns, Sporting and Match Rifles, and Revolvers. In Two Volumes: Vol. I., Game and Wildfowl Guns; Vol. II., The Rifle and Revolver. By the late J. H. WALsh, "Stonehenge," Editor of the "Field," Author of "Dogs of the British Islands," "The Greyhound," "British Rural Sports," \&c. Demy 8vo., in Two Volumes, price i5s. each, by post I5s. 6d. each.

" A perusal of Mr. Walsh's book has forced upon us the conclusion, one that will be shared by nearly every reader, that it is indisputably the standard work on the subject, and is likely long to remain so-a position it richly merits. . . . We are only fulfilling a duty to the public when we say that no man connected in any way with guns or gunnery should be without a copy of Mr. Walsh's masterly volume."-Birmingham Daily Gazette, Nov. 21, 1882.

\section{Sporting Sketches with Pen and Pencil.}

By the late Francis Francis and A. W. Cooper. Demy 4to., with twelve full-page illustrations, some of which contain Portraits of Sporting Celebrities, and twentyfour vignettes, price Ios. 6 d., by post I is.

Contents.-The First of September; A Day in a Punt; Mark Cock! Trouting; Long Tails and Short Ones; Paying the Pike; Rabbit Shooting; Roaching; Grouse Shooting; Salmon Fishing; Snipe Shooting; Grayling Fishing.

\section{The Cattle of Great Britain:}

Being a Series of Articles on the Various Breeds of Cattle of the United Kingdom, their History, Management, \&c. Edited by the late J. Coleman, Editor of the Farm Department of the "Field," and formerly Professor of Agriculture at the Royal Agricultural College, Cirencester. Illustrated with full-page engravings drawn principally from life by Harrison Weir. In Imperial 4to., bevelled boards, gilt edges, price I 8 s., by post I 8 s. $9 \mathrm{~d}$.

"Field" Office, Windsor House, Bream's Buildings, E.C. 


\section{The Sheep and Pigs of Great Britain:}

Being a Series of Articles on the Various Breeds of Sheep and Pigs of the United Kingdom, their History, Management, \&c. Edited by the late J. Coleman, Editor of the Farm Department of the "Field," and formerly Professor of Agriculture at the Royal Agricultural College, Cirencester. Illustrated with full-page engravings drawn principally from life by Harrison Weir. In Imperial 4to., bevelled boards, gilt edges, price $18 \mathrm{~s}$., by post $\mathrm{r} 8 \mathrm{~s}$. $9 \mathrm{~d}$.

\section{Estate Management:}

A Practical Handbook for Landlords, Agents, and Pupils. By Charles E. Curtis. With a Legal Supplement by a Barrister. Third Edition. In demy 8 vo., price Ios. 6 d., by post IIs.

Contents.-Letting and Leases; Farm Valuations; Forestry; Underwood; Fences; Grasses suitable for Woods and Plantations; The Home Farm; Repairs and Materials; The Blights of Wheat and other Cereals; Accounts; Useful Rules of Arithmetic and Mensuration.

\section{Poultry for the Table and Market}

Versus Fancy Fowls, with an Exposition of the Fallacies of Poultry Farming. By W. B. Tegetmeier, F.Z.S. Second Edition nearly ready, revised and enlarged, with many additional engravings. Demy 8 vo., price 2s. 6 d., by post 2 s. 9 d.

Contents.-Introductory; Game Fowls; Dorking ; Cochins ; Brahmas ; Langshans, Plymouth Rocks, and Wyandottes; Malays, Indian Game, and Aseels; French Table Breeds-Houdans, Crevecœur, and La Fleche; Non-sitting VarietiesSpanish, Minorcas, Andalusian, and Leghorn; Non-sitting and Other Varieties; Housing; Feeding; Hatching; Rearing the Chicken; Breeding for the MarketEggs; Breeding for the Market-Chickens; Fattening; Turkeys and Guinea Fowl; Ducks; Geese ; Diseases of Poultry; Fallacies of Poultry Farming; Fowls in Small Runs; Caponising.

"Field" Office, Windsor House, Bream's Buildings, E.C. 


\section{ANDDERSONS' Celebrated 'Breadalbane ' Waterproof Shooting Costume}

The GREATEST ADVANCE which has been made during late years in this direction is that effected by Messrs. Andersons, of 37, Queen Victoria-street.

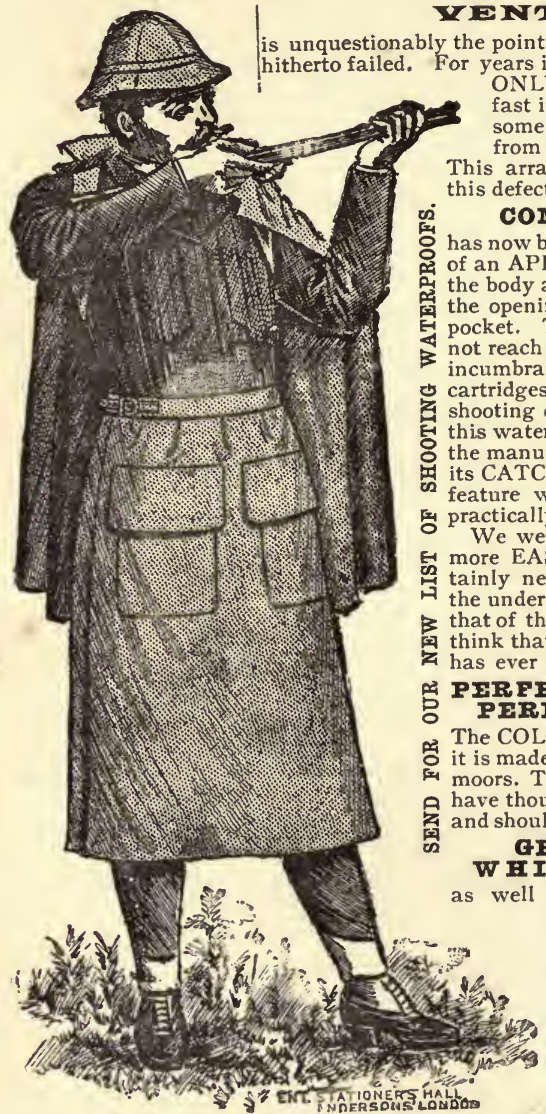

which effective waterproofing has ears it has been an accepted fact that the ONLY comfortable waterproof to walk fast in and to shoot well in is a CAPE of some kind which can be THROWN BACK from the right shoulder instantaneously. This arrangement, however, has always had -it does not protect the knees.

\section{COMPIRTE PROTFCTION}

Sy now been attained by the simplecontrivance of an APRON or SKIRT, which winds round 2 the body and fastens at the side, so as to leave 孚 the opening immediately over the cartridge pocket. The fold is so arranged that wet will not reach this pocket, and it is nevertheless no incumbrance to the hand when in want of cartridges from the dry pocket of the ordinary shooting coat. We were surprised on trying this waterproof at the PERFECT way in which the manufacturers had contrived to PREVENT its CATCHING the KNEES in WALKING, a o feature we expected to find would render it actically useless. more EASY over-garment to walk in was certainly never made. The VENTILATION of $\rightarrow$ the underneath part or apron is as complete as $\$$ that of the cape itself, and we are inclined to that it is the FIRST GARMENT which COMBINED FRFFCT WATERPROOEING.

COLOUR of the waterproof cloth of which . Cape, I $\frac{1}{2} l b . ;$ apron, $1 \frac{1}{2} l b . ;$ carrier houlder strap, $\frac{1}{2} \mathrm{lb}$. It appears to us that for GROUSE DRIVING AND WIITE IARI D RIVING, as for carrying in case of rain when walking the moors, the garment will become fashionable.

The cape is also made as an INVERNESS, throwing back for shooting; but, of course, this adds weight, and is warmer for

STANDING in the BUTT\&.

The CAPE which goes with the apron mentioned already seems to us equally useful for low-country shooting, when COMBINED with THIGH KNEE LEGGINGS. These articles of DEFENCE AGAINST RHEUMATISM, made of the same colour and material as the $I \frac{1}{2} l b$. cape, weigh $90 z$., and we think that no one will think $2 \mathrm{lb}$. 10z. too heavy a tax for a

\section{PRRFECTIY DEY SKIN AND FREI VENTIAATON.}

\section{G. T. Teasdale Buckell.}

Carefully Note $\mathrm{NT}$ TR $\mathrm{T}$ Th $\mathrm{T}$ ' The Waterproof Manufacturers, Address, AIDIRUNUN 37, QueEN VICTORIA St, LONDON, E.C. 



FOI TRTFFN DAY TTSE

\section{RETURN CIRCULATION DEPARTMENT}

TO $\rightarrow 202$ Main Library

\begin{tabular}{l|l|l}
\hline $\begin{array}{l}\text { LOAN PERIOD } 1 \\
\text { HOME USE }\end{array}$ & 2 & 3 \\
\hline 4 & 5 & 6 \\
\hline
\end{tabular}

\section{ALL BOOKS MAY BE RECALLED AFTER 7 DAYS}

AENEWMLS AND RECHARGES MAY BE MADE A DAYS PAHOA TO DUE DATE.

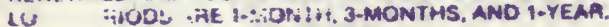

RENEWALS: CALL (415) SA2-3405

\section{DUE AS STAMPED BELOW}

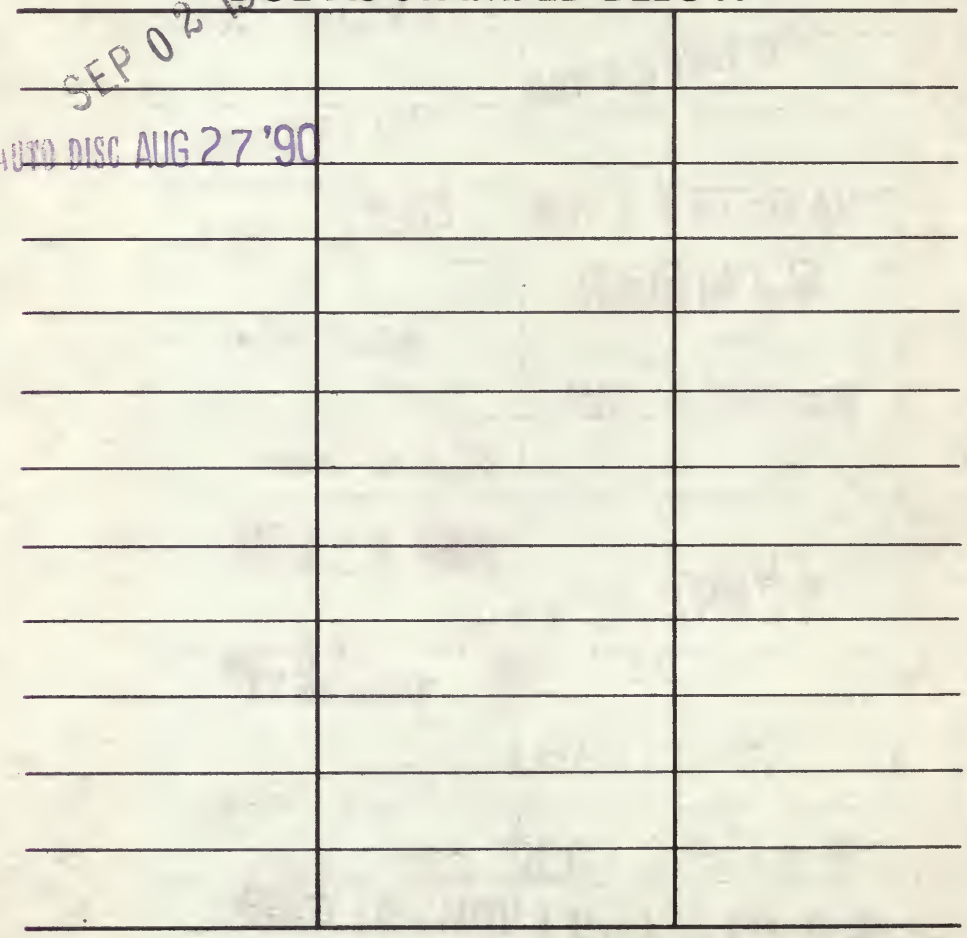

UNIVERSITY OF CALIFORNIA, BERKELEY

FORM NO. DD6, 60m, 1/83 BERKELEY, CA 94720 


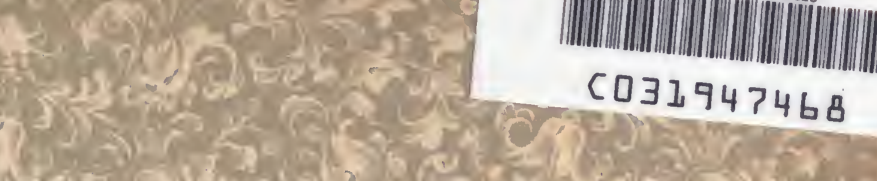

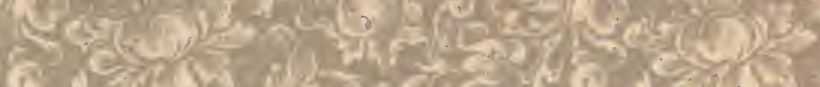

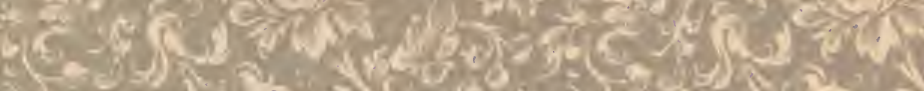

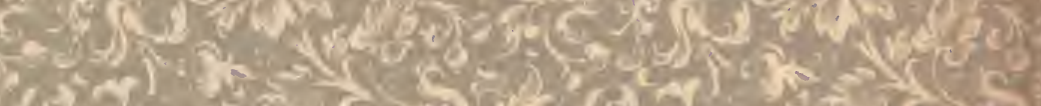

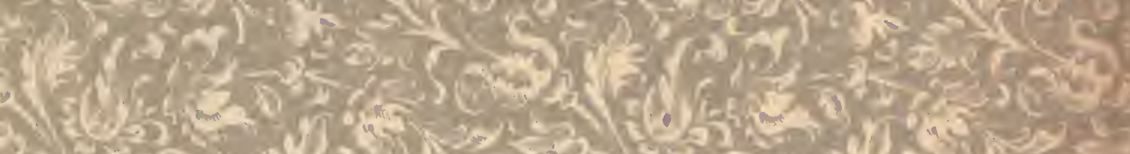
F.

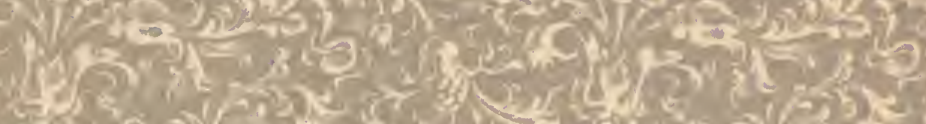

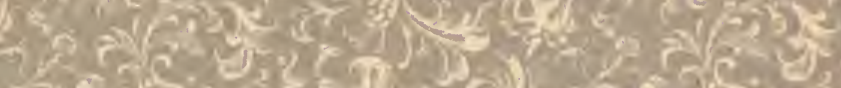

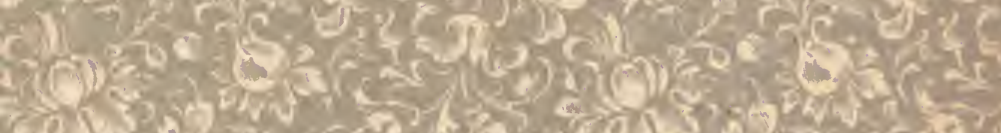

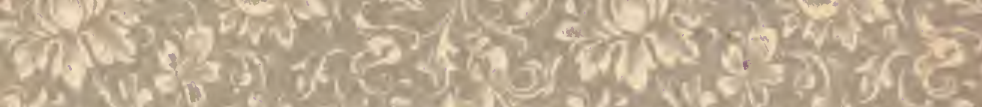

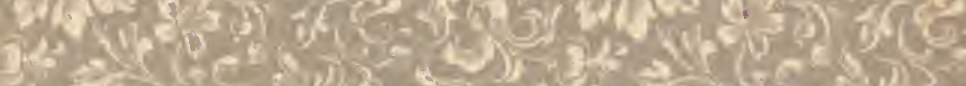

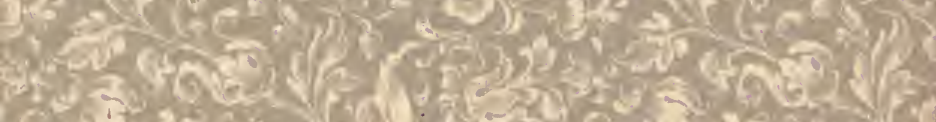

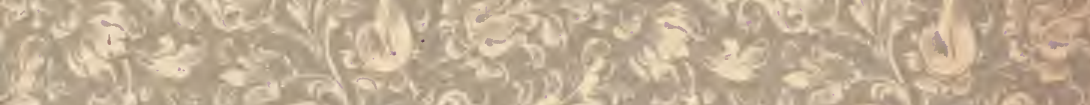

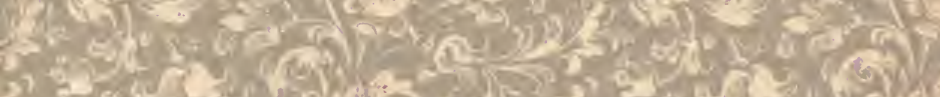

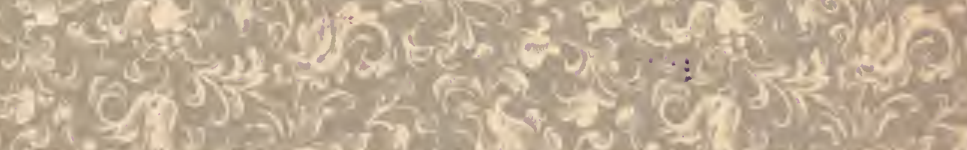
5 - 51 .

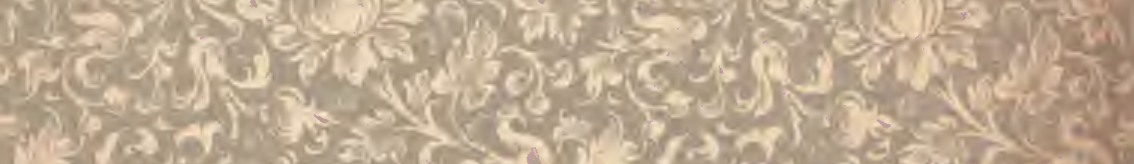

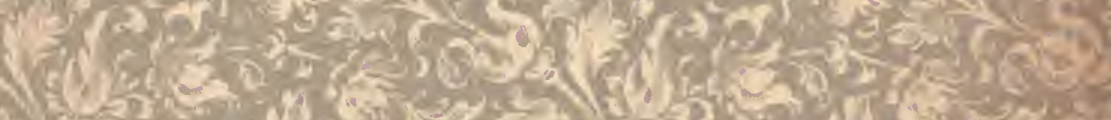

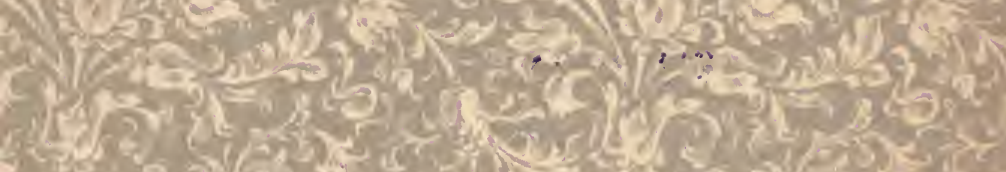

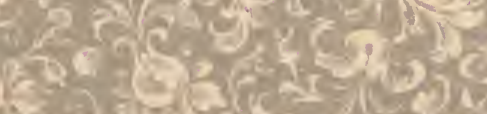

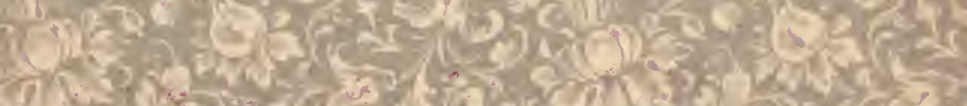


